
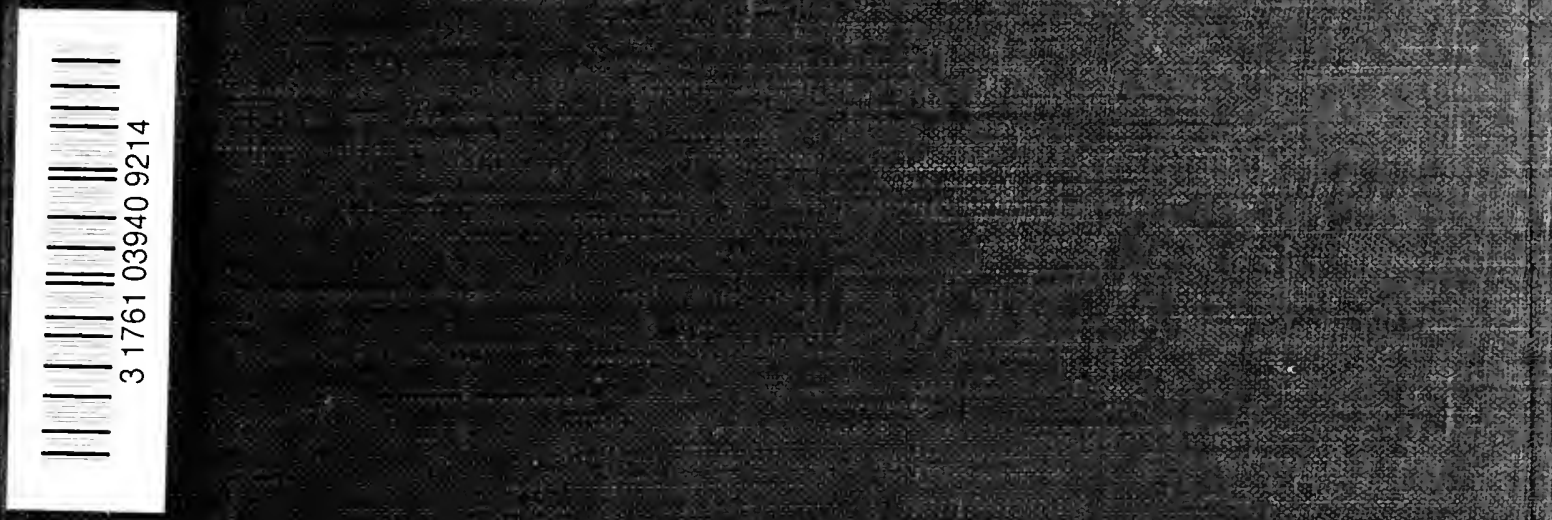
, 
- $w^{0} \cdot 2 w^{x}$

$A^{2} N^{N} \cdot{ }^{2+}$

$\beta^{n}$ 
Digitized by the Internet Archive in 2007 with funding from Microsoft Corporation 



\title{
$5+34$
65469
}

\section{Carnegie Endowment for International Peace}

DIVISION OF ECONOMICS AND HISTORY

JOHN BATES CLARK, DIRECTOR

EPublications

\section{FEDERAL MILITARY PENSIONS IN THE UNITED STATES}

\author{
BY \\ WILliaM H. GLASSON, Ph.D. \\ Professor of Political Economy and Social Science \\ Trinity College, North Carolina
}

EDITED BY

DAVID KINLEY

Professor of Political Economy, University of Illinois

Member of Committee of Research of the Endowment

\section{NEW YORK \\ OXFORD UNIVERSITY PRESS}

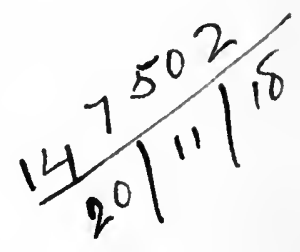

AMERICAN BRANCH: 35 WEST 32ND STREET

London, Toronto, Melbourne and Bombay 
COPYRIGHT 1918

BY THE

CARNEGIE ENDOWMENT FOR INTERNATIONAL PEACE

2 JaCkson Place, Washington, D. C.

Press of Byron S. Adams

Washington, D. C. 


\section{INTRODUCTORY NOTE BY THE DIRECTOR}

The Division of Economics and History of the Carnegie Endowment for International Peace is organized to "promote a thorough and scientific investigation of the causes and results of war." In accordance with this purpose a conference of eminent statesmen, publicists, and economists was held in Berne, Switzerland, in August, 1911, at which a plan of investigation was formed and an extensive list of topics was prepared. An elaborate series of investigations was undertaken, and, if the war had not intervened, the resulting reports might have been expected, before the present date, in printed form.

Of works so undertaken some aim to reveal direct and indirect consequences of warfare, and thus to furnish a basis for a judgment as to the reasonableness of the resort to it. If the evils are in reality larger and the benefits smaller than in the common view they appear to be, such studies should furnish convincing evidence of this fact and afford a basis for an enlightened policy whenever there is danger of international conflicts.

Studies of the causes of warfare reveal, in particular, those economic influences which in time of peace bring about clashing interests and mutual suspicion and hostility. They show what policies, as adopted by different nations, reduce the conflicts of interest, inure to the common benefit, and afford a basis for international confidence and good will. They tend, further, to reveal the natural economic influences which of themselves bring about more and more harmonious relations and tend to substitute general benefits for the mutual injuries that follow unintelligent self-seeking. Economic internationalism needs to be fortified by the mutual trust that just dealing creates; but just conduct itself may be favored by economic conditions. These, in turn, may be created partly by a natural evolution and partly by the conscious action of governments; and both evolution and public action are among the important subjects of investigation. 
An appeal to reason is in order when excited feelings render armed conflicts imminent; but it is quite as surely called for when no excitement exists and when it may be forestalled and prevented from developing by sound national policies. To furnish a scientific basis for reasonable international policies is the purpose of some of the studies already in progress and of more that will hereafter be undertaken.

The war has interrupted work on rather more than a half of the studies that were in progress when it began, but it has itself furnished topics of immediate and transcendent importance. The costs, direct and indirect, of the conflict, the commercial policies induced by it and, especially, the direct control, which, because of it, governments are now exercising in many spheres of economic activity where formerly competition and individual freedom held sway, are phenomena that call, before almost all others, for scientific study. It is expected that most of the interrupted work will ultimately be resumed and that, in the interim before this occurs, studies of even greater importance will be undertaken and will be pushed rapidly toward completion.

The publications of the Division of Economics and History. are under the direction of a Committee of Research, the membership of which includes the statesmen, publicists, and economists who participated in the Conference at Berne in 1911, and two who have since been added. The list of members at present is as follows:

Eugène Borel, Professor of Public and International Law in the University of Geneva.

Charles Gide, Professor of Comparative Social Economics in the University of Paris.

H. B. Greven, Professor of Political Economy and Statistics in the University of Leyden.

Francis W. Hirst, 27 Campden Hill Square, London, W.

David Kinley, Dean of the Department of Economics in the University of Illinois.

Henri La Fontaine, Senator of Belgium.

His Excellency Luigi Luzzatti, Professor of Constitutional 
Law in the University of Rome; Secretary of the Treasury, 1891-1893; Prime Minister of Italy, 1908-1911.

Gotaro Ogawa, Professor of Finance in the University of Kioto, Japan.

Sir George Paish, Plains Hill, Limpsfield, Surrey, England.

Maffeo Pantaleoni, Professor of Political Economy in the University of Rome.

Paul S. Reinsch, United States Minister to China.

His Excellency Baron Y. Sakatani, formerly Minister of Finance; formerly Mayor of Tokio.

Harald Westergaard, Professor of Political Science and Statistics in the University of Copenhagen.

The function of members of this Committee is to select collaborators competent to conduct investigations and present reports in the form of books or monographs; to consult with these writers as to plans of study; to read the completed manuscripts and to inform the officers of the Endowment whether they merit publication in its series. This editorial function does not commit the members of the Committee to any opinions expressed by the writers. Like other editors, they are asked to vouch for the usefulness of the works, their scientific and literary merit, and the advisability of issuing them. In like manner the publication of the monographs does not commit the Endowment as a body or any of its officers to the opinions which may be expressed in them. The standing and attainments of the writers selected afford a guarantee of thoroughness of research and accuracy in the statement of facts, and the character of many of the works will be such that facts, statistical, historical, and descriptive, will constitute nearly the whole of their content. In so far as the opinions of the writers are revealed, they are neither approved nor condemned by the fact that the Endowment causes them to be published. For example, the publication of a work describing the attitude of various socialistic bodies on the subject of peace and war implies nothing as to the views of the officers of the Endowment on the subject of socialism; neither will the issuing of a work, describing the attitude of business classes toward 
peace and war, imply any agreement or disagreement on the part of the officers of the Endowment with the views of men of these classes as to a protective policy, the control of monopoly, or the regulation of banking and currency. It is necessary to know how such men generally think and feel on the great issue of war, and it is one of the purposes of the Endowment to promote studies which will accurately reveal their attitude. Neither it nor its Committee of Research vouches for more than that the works issued by them contain such facts; that their statements concerning them may generally be trusted, and that the works are, in a scientific way, of a quality that entitles them to a reading.

John Bates Clark, Director. 


\section{EDITOR'S PREFACE}

We have long needed a complete account and review of our pension system. Professor Glasson has supplied this lack by a volume which will take its place among the important contributions to the history of our country. His survey of the subject, from the beginning of our history until a recent date, is thorough, full and impartial. He not only furnishes us with a complete account of the pension system, but also enables us to judge of the effects of such a system as we have hitherto employed on the civil and political life of a democracy.

The story is both heartening and depressing. The reader who is also an American citizen will take a pardonable pride in the fact that, as the story shows, the American people have been moved by generous impulses in their provision for those who at one time or another risked their lives in the military and naval service of their country. But he will be depressed by the account of moral degeneration and political corruption that gradually crept into the administration and operation of our old pension system as in the lapse of time the sterner motives and higher ideals which led to its adoption faded into the dim background of the memories of the war.

The fears expressed at the close of the Revolution that the establishment of a class of pensioners would endanger liberty and democracy had long passed away when the Civil War came upon the country. The impulse then was to make every proper provision for our soldiers and those dependent on them. As is usual under all governments when money is to be paid out to numerous individuals in the community, a class of people fastened themselves as parasites on the beneficiaries. The pension claim agent appeared early on the scene. Under pretense of assisting prospective pensioners, he soon reached a stage where he absorbed a large part of the benefit of the country's generosity. He was in very truth a blood-sucker on the pensioner, although 
posing as his friend. When his evil activities were attacked by disinterested citizens, he stirred up the prejudices of those he was fleecing by imposing on their credulity and leading them to believe that their interests and his were the same. Assisted by political leaders from time to time, he gradually molded the pensioners into a political faction so numerous and powerful that in time it came to hold the balance of political power. Party leaders and parties formed their platforms and policies at its behest. The public treasury became, in the minds of many, a proper source of loot.

The evil influence of the above trend on the moral and patriotic character of the pensioners themselves soon became evident. Many of them came to look upon their pensions as rewards for service rather than as tokens of the country's appreciation of their patriotism. But the pension which any country can ordinarily pay is wholly inadequate if regarded as a reward for service. Naturally, therefore, the pensioners insisted on larger pensions, and, assisted by the claim agent and the politician, they pushed their claims until the financial drain on the country became a serious one. This is likely to happen in a democracy.

The moral degeneration caused in time by the changing view of the true character of pensions led also to the evil of extending them to men whose service was brief and resulted in no injury to them. Moreover, pensions were taken without compunction by some men who, while technically entitled to them, had other means of adequate support and, indeed, were sometimes rich; to say nothing of young widows of old soldiers. For such people to take pensions is to throw a shadow of graft on the whole system.

As a result of these and other evil influences, the pension administration, and indeed the whole pension system, became gradually discredited. Nobody begrudged the deserving pensioner his pittance from the public treasury, but the developing rottenness of the system led the public at last to look with more or less suspicion on applications for pensions, even when they were meritorious. 
When the present war broke out between the United States and Germany, the necessity of early action to provide for our soldiers and their families was strongly felt by the government. A continuance of the old system would have been probably impracticable and certainly undesirable, because of the discredit under which it had come. True, under the inspiration of war the patriotic viewpoint becomes reestablished, and the evils of any system intended for the benefit of our soldiers would have sunk more or less into the background of our memory. But it was fairer to the soldiers, and better for both the public and the administration, to find some other means of setting at rest the anxiety of the men in our army about the future of their families. The new plan of soldiers' insurance is therefore a welcome innovation. It has the advantage of inciting more strongly the soldier's self-respect, of giving him, as it were, a financial "stake" in the provision made for him, by compelling his participation in the payment, and at the same time of being less likely in the long run to arouse criticism and opposition because of the drain on the public treasury. Already, however, there are indications that the soldiers will have to be protected against the machinations of the successor of the claim agent. The "soldiers' lawyer" is already offering his assistance for a consideration to secure for the soldier rights for obtaining which he needs no assistance. Congress, the administration and the public should settle this matter early by making it impossible, through severe legal penalties, for such people to impose upon our men. It should be made perfectly clear to every man that in this matter he may deal without expense directly with the agents of the government. In the long run, to be sure, even the agents of the government are likely both to develop an administrative routine which will make difficulties for applicants and, for political or personal advantage, perhaps to inject some elements of graft or extravagance into the administration of the new insurance system. Against these evils, too, the public must keep wide awake and make proper provision. On the whole, however, we must welcome the new insurance plan as a great advance on the old- 
fashioned pension system, both because of its direct pecuniary and moral advantages to the injured, and the less likelihood of its degeneration.

The editor takes the opportunity to express his great satisfaction with the thoroughness with which Professor Glasson has done his work.

David Kinley,

Editor. 


\section{FOREWORD}

The present volume embodies the principal results of an investigation in the subject of military pensions carried on at intervals for many years. In 1900 I broke new ground with a monograph on the History of Military Pension Legislation in the United States, published in the Columbia University Studies in Political Science. This survey of the pension legislation of the United States was limited in scope and left room, in particular, for more comprehensive study of the various aspects of Civil War pensions. As the years passed, the federal pension system also underwent important change and development. From time to time I published articles in this field and delivered lectures on the subject at the Johns Hopkins University, Princeton University and elsewhere. In 1913 an offer of substantial assistance from the Carnegie Endowment for International Peace encouraged me to enter actively upon a long cherished plan to make a fresh and better rounded investigation of the federal military pension system of the United States from the beginning. The present work is the result. Occasionally, where no important changes or additions could be made, some passages follow rather closely the text of my earlier work. I have not thought it necessary to make specific reference in such cases.

Though begun in time of peace, this investigation reaches its conclusion at a time when the United States is a participant in a world war. Within a few weeks the old pension system has been set aside and rejected as a means of protecting the soldiers of the present war and their dependent relatives against the hazards of death and disability. The old plan of pensions continues to apply to our previous wars, but for the future the United States has entered upon an immensely important experiment in compensation and insurance. Although my manuscript had been completed before the entry of the United States into the great war, I was glad, in giving it a revision, to have the 
opportunity of adding as an appendix an analysis of the so-called War Insurance Law of October 6, 1917.

I am indebted to the Carnegie Endowment for International Peace for the financial assistance which enabled me to bring this investigation to a conclusion in the present rather than in an indefinite future. Dean David Kinley, who ably represents the Carnegie Endowment as editor, has placed me under obligation to him for patience and friendly encouragement as well as for wise counsel and suggestion drawn from his mature experience in scholarly writing. Two of my former students, Messrs. Holland Holton and B. W. Barnard, have given me most efficient and painstaking assistance in collecting material in the Library of Congress. To various members of the staff of that great library, where the investigator is always made welcome, I owe thanks for courteous assistance. Mr. Frank F. Rosenblatt of New York aided me in the examination of articles on the subject of pensions in newspapers and periodicals. The excellent index was prepared by E. S. Nock, of the Carnegie Endowment. William H. Glasson.

Trinity College, Durham, N. C.

November, 1917 . 


\section{CONTENTS}

PAGE

Introduction $\ldots \ldots \ldots \ldots \ldots \ldots \ldots \ldots \ldots \ldots \ldots \ldots \ldots$

PART I

Pensions Based on Military Service Prior to

MARCH 4, 1861

CHAPTER

I English and Colonial Origins............... 9

II Revolutionary Pensions, $1776-1789 \ldots \ldots \ldots \ldots \ldots 19$

III Revolutionary Pensions, 1789-1878........... 54

IV Regular Army and Navy Pensions............. 98

V War of 1812, Indian Wars and Mexican War Pensions 108

$$
\text { PART II }
$$

Pensions Based on Military Service After MARCH 4, 1861

I Civil War Pensions-The General Law System..... 123

II Civil War Pensions_-Arrears Legislation-Pensions and Politics ........................ 148

III Civil War Pensions-Act of June 27, 1890, and Service-Pensions-Pensions and Politics......... 204

IV Special Pension Legislation ............... 275

Appendix

I The War Insurance Law of October $6,1917 \ldots \ldots .283$

II Brief Outline of the Provisions and Schedules of the

Act of October 6, 1917 .............. 287

Bibliographical Note ................. 296

Index . . . . . . . . . . . . . . . . . . . . . . . . . 299 


\section{FEDERAL MILITARY PENSIONS IN THE UNITED STATES}

\section{INTRODUCTION}

A military pension is a regular payment made by a government to one who has served in its armed forces, or to his widow or dependent relatives. It is a gratuity given to former soldiers or their relatives for reasons satisfactory to the government, whether as compensation for physical injuries, or to relieve want, or purely as a reward. Army pay and pensions are not matters of contract. No claim for a pension can be enforced against the state. If the sovereign community requires the service, citizens must obey the call to the colors as a matter of duty and without regard to a prospective compensation for injuries or sacrifices. Even when the benefits of pension provisions have been promised in order to secure voluntary enlistments in the army, soldiers must rely solely upon the good faith of the government for the fulfilment of such promises. In the performance of his duty, a soldier may become the victim of wounds, casualties, or disease, but these incidents of warfare give him no right to a pension enforcible against an unwilling government. Whether a military pension be granted in recompense of injuries or as a mark of gratitude, it is in law the bounty of the state. ${ }^{1}$

Among the people of the United States there has always been a strong feeling that the government is under moral obligation to provide for the aid and relief of those who have been disabled in its military service and for the support of the widows and dependent relatives of the slain. This sense of national

1 The Supreme Court of the United States has held that no pensioner can claim a vested legal right to his pension, but that pensions are the bounties of the government, which Congress has the right to give or recall, increase or diminish, at its discretion. See 107 U. S. Reports, 64-68. 
responsibility has brought about more or less adequate pension provisions for the benefit of the soldiers of all our wars. From the very beginning of our government, it has been usual for Congress, in passing laws to raise men for the army and navy, to promise pensions to those who should be wounded or disabled in the military service. Frequently such laws have also committed the government to the payment of pensions to the widows, orphans, or dependent relatives of soldiers who should lose their lives as the result of the performance of military duty. Thus the maintenance by the United States of a reasonable pension system has been clearly in accord with principles of justice and good faith. This country, however, has not contented itself with merely keeping its promises. It has done much more than provide pensions for invalids, the maimed, and the dependent and needy relatives of the slain. Those who completed the period of their military service in health and strength have in later years been admitted to enjoy the bounty of the government. The fact of military service has been made the basis of pension grants, although such service did not cause disability or death. In its grants for the reward and relief of soldiers the United States pension system has become more generous-even lavish-than that of any other nation in the history of the world.

The pensions that have been granted to our former soldiers may be divided into invalid-pensions (or disability-pensions) and service-pensions. An invalid-pension is one granted to a soldier on account of wounds or injuries received, or disease contracted, in the military service. A service-pension is granted in recognition of military service for a specified length of time, whether a few weeks or months or many years. The applicant for a service-pension is not required to show that he was injured, or contracted disease, as the result of his performance of military duty. In many cases limited service-pensions have been given to those soldiers who served for a specified period of time during a war provided they are also able to meet certain additional requirements not connected with military service. Such requirements may be indigence, inability to perform manual labor, the attain- 
ment of a certain age, or the existence of disease or disability not of service origin.

Logically included in an invalid-pension system are provisions granting pensions to the widows and dependent relatives of soldiers whose death was brought about by causes originating in the military service. Widows' pensions of this class are usually granted regardless of the length of the soldiers' service. Connected with a service-pension system are laws granting pensions to widows and dependent relatives of soldiers, who performed a required length of service, without regard to the cause of death. Pensions to widows are sometimes conditioned on the date of marriage, whether before, during, or after the soldiers' service, or before or after a specified date. Sometimes the age of a widow determines her eligibility for a pension. Generally widows forfeit their pensions by remarriage.

The present work does not deal with the many and varied provisions for the reward and relief of former soldiers made by the commonwealths of the American union. Such local measures include pensions, the relief of indigent soldiers, soldiers' homes, preferment in appointments to public office, the maintenance of institutions for soldiers' widows and orphans, and the exemption of former soldiers from various public obligations or duties. In all of the southern states which fought to withdraw from the Union, pension systems are maintained for the benefit of the soldiers of the Confederate armies and their widows. ${ }^{1}$ The story of the provisions made by the states for pensions and soldiers' relief would be a long and complicated one.

Nor does the writer propose to include in this volume all that has been done by the federal government for the benefit of former soldiers and their relatives. Retirement pay has been provided for the regular army and navy. Vast areas of the public lands have been granted to ex-soldiers as the gift of a grateful

\footnotetext{
1 For brief accounts of the Confederate pension systems, see the article on "Confederate Pensions" in Hart and McLaughlin's Cyclopedia of American Government and also an article by W. H. Glasson on "The South's Care for Her Confederate Veterans" in the Review of Reviezis for July, 1907.
} 
nation. Artificial limbs and mechanical appliances have been provided for the maimed and disabled. Many thousands of veterans have been sheltered and cared for in national soldiers' homes with branches in various sections of the country. ${ }^{1}$ In employment in the national civil service, preference has been given to former soldiers over other citizens equally or better qualified. When death has claimed the veterans, under certain circumstances the government has paid the expenses of their last illness and burial and has erected headstones to mark their graves. Many of the dead have found their last resting place in beautiful national cemeteries.

In pensions the federal government has paid out considerably more than five billions of dollars to the soldiers of its various wars. The pension system is by far the most important provision that has been made for the recognition and reward of military services. The origin of this system, its development, its application to our several wars, its administration, and its political, economic, and moral relations and effects form the subject matter of this investigation.

The pension laws of the United States make a sharp distinction between military service in the "old wars" before March 4, 1861, and service in the armed forces of the United States since that date. Accordingly Part I deals with pensions based on service rendered prior to March 4, 1861, and Part II deals with pensions granted on account of military operations from the beginning of the Civil War to the present. ${ }^{2}$ In so far as the pension laws can be classified according to wars or on some other important principle, the topical plan of treatment has been adopted. Within the various topics, the subject has been treated

${ }^{1}$ In the first quarter of 1915 there were 21,000 veterans cared for in twelve national soldiers' homes.

2 On October 6, 1917, a new and comprehensive act became law providing insurance and compensation for death or disability for the benefit of soldiers and sailors employed in the armed forces of the United States. Thus the participation of the United States in the European War has opened a new era in our national provisions dealing with death and disability caused by military service. The old pension system remains in force as applied to military service before October 6, 1917. 
chronologically. Considerable information regarding the administration of the pension laws is presented incidentally, but an adequate and detailed treatment of that phase of the subject would furnish material for a separate volume. Reliance has been placed largely upon the facts brought out in the narrative to exhibit the political, economic, and moral effects of the pension system.

A study of our military pension system must deal with many technicalities and difficult distinctions. It has been constantly the aim of the writer to achieve precision of statement without overmuch burdensome detail. He can not hope to have been always successful. Doubtless general readers will find details given to a wearisome extent in some of the chapters. On the other hand expert critics may think that some statements should have been further qualified, and matters omitted for the sake of simplicity and clearness may seem to them important. If on the whole the work is found to present what is most essential in a clear and trustworthy manner, the writer will feel that he has not labored in vain. 


\section{PART I}

PENSIONS BASED ON MILITARY SERVICE PRIOR TO MARCH 4, 1861 


\section{CHAPTER I}

\section{English and Colonial Origins}

It was in the reign of Elizabeth, not long before the beginning of English colonization in America, that the problem of caring for poor, sick, and maimed soldiers first compelled definite national recognition and action in England. What to do with the great numbers of soldiers returning from her wars was a chronic and difficult question. The able-bodied and unemployed were given to rioting, violence, and theft; the disabled and maimed became vagabonds and beggars. ${ }^{1}$ The queen herself, when she went out to take the air, was troubled with the importunities of "these miserable creatures." Agencies which formerly had extended much relief to such poor, infirm, and maimed persons had been destroyed in the decay of the feudal system and the dissolution of monasteries and other charitable foundations. "A statement of the inconveniences arising upon the dissolution and going [sic] away of hospital lands and revenues," submitted to Cecil Lord Burghley in 1593, mentions "taking relief from the aged and impotent poor, disfurnishing the realm of places to send maimed soldiers to," and "enfeebling their hearts when they know not how to be provided for if they are maimed."' Parliament was compelled to deal with the problem by reasons similar to those which brought about the poor laws of Elizabeth's time. In the session of 1592-3 was passed the first statute "for reliefe of Souldiours.",

This English pension law is interesting as a precursor of the American colonial pension legislation of the first half of the seventeenth century. It provided for those who had served since March in the year of the Spanish Armada. The preamble recited

1 E. P. Cheyney: A History of England. From the Defeat of the Armada to the Death of Elizabeth, i, 184-185.

${ }^{2}$ Chelsea Hospital Papers, 5.

335 Elizabeth, ch. 4. 
that "forasmuch as it is agreeable with Christian Charity Policy and the Honor of our Nation, that such as have since the 25th day of March, 1588, adventured their lives and lost their limbs or disabled their bodies, or shall hereafter adventure their lives, lose their limbs, or disable their bodies, in defence and service of Her Majesty and the State, should at their return be relieved and rewarded to the end that they may reap the fruit of their good deservings, and others may be encouraged to perform the like endeavors: Be it enacted," and so forth. Rates for the relief of sick, maimed, or disabled soldiers or mariners were to be levied in the parishes. The pensions were to be payable quarterly in amounts directed by the justices in Quarter Sessions and were not to exceed ten pounds a year to a private soldier nor twenty pounds to a lieutenant. Soldiers were chargeable to the place where they were pressed, or, if not pressed, to the place of residence or birth. Those who begged were liable to a forfeiture of their pensions. The act was to continue in force only to the end of the next session. It soon met with obstacles in execution. There was complaint that the justices sent the applicants from the place where they were impressed to the place where they were born and vice versa, and that the counties generally failed to certify the amounts collected for soldiers. ${ }^{1}$

Later acts continued and amplified the statute of 1592-3, and by 1599 the system seems to have been fairly in operation. In the last parliament of Elizabeth (1601), in view of the increasing numbers to be provided for, a new statute for the "necessarie reliefe of souldiers and mariners" was enacted. ${ }^{2}$ It contemplated a similar plan of relief, but amplified the details of administration and increased the maximum contribution of the parishes. This law was continued in force from time to time during the reigns of James I and Charles I, and in 1640 its application was extended "until some other Act be made touching the statutes so continued." 3

1 Chelsea Hospital Papers, 6.

243 Elizabeth, ch. 3.

316 Car. I, ch. 4. 
During the Commonwealth there is evidence of the defraying of pensions to soldiers from national funds rather than from the proceeds of local taxation in counties. Sums were appropriated out of the receipts from sequestrations and also were charged upon the excise. After the Restoration, a committee of the House of Commons inquired into the matter of relief for sick and maimed soldiers. Many petitions were presented on their behalf. An act was passed in 1662 which again made such relief a charge on the local rates. ${ }^{1}$ But, because of the use of national funds for this purpose during the Commonwealth, the act was felt to be a grievance by those who had been relieved of this burden, and it was not renewed when it expired. When, between 1680 and 1690, England came to have a standing army with the permanent enlistment of troops, it was found necessary to establish a pension provision under some new plan. The method adopted was the care of invalids in what we now call a soldiers' home. In 1681 Charles II announced by letters patent the intention to erect and endow an institution called Chelsea Hospital. $^{2}$ This was to be a home for such land soldiers as were, or might be, lame or infirm in the service of the Crown. The public were expected to contribute liberally. Funds, however, came in slowly, and the building went on for many years. The king contributed from the secret service money, and later the plan of making regular deductions from the pay of troops for the support of the hospital was hit upon. In 1692 the institution finally was opened.

Chelsea Hospital was intended for noncommissioned officers and men. At the opening it provided a home for somewhat less than 500 persons, and it contained about this number up to 1816 . It is worthy of note that the buildings were designed by Sir Christopher Wren. From the beginning the hospital was inadequate to receive all applicants, and there grew up a custom of making allowances to soldiers who awaited vacancies. At first

114 Car. II, ch. 9.

2 Chelsea Hospital Papers, 13-16. This valuable compilation is full of information regarding the early history of pensions to soldiers in England. 
there were about 100 out-pensioners, but soon the number increased until too great for the revenue of the institution from deductions from army pay. Beginning with 1703, the funds of the hospital were supplemented from time to time by grants made by Parliament at the cost of the exchequer. The number of out-pensioners became very large, being 13,931 in 1776 and 20,592 in $1789 .{ }^{1}$ From time to time, when war broke out, companies of invalids were raised out of the pensioners for light duty. Thus under the above plan England was at the time of the American Revolution providing for a considerable list of military pensioners.

Soon after provision had been made for the relief of private soldiers by the building and endowment of Chelsea Hospital and the establishment of its list of out-pensioners, disbanded officers of the British army were allowed half pay. ${ }^{2}$ This was done beginning with 1697 or 1698 . Such officers were liable to be called into service on the outbreak of war. An illustration of the employment of retired officers and invalid soldiers occurred on the occasion of the Jacobite rebellion in the autumn of 1715 . Then the whole of the officers on half pay were called upon to hold themselves ready for service, and twenty-five companies of Chelsea pensioners were formed to take over the duties of the garrisons and to release the regular troops for work in the field. ${ }^{3}$ This system remained in force for many years, and, as we shall see later, a similar plan was introduced in America during the Revolution. There were also prevalent about this same period various arrangements for relieving the widows of deceased officers at the expense of the army pay roll-such as the carrying of a fictitious man on the roll of each company whose pay was taken for the widows' fund. In some instances mere children received commissions in regiments in which their fathers had commanded. ${ }^{4}$

${ }_{1}$ Chelsea Hospital Papers, 40, 50, 52, 53, 85.

2 G. R. Gleig, Chelsea Hospital and Its Traditions, i, 73. Also Fortescue, History of the British Army, i, 385-389.

3 Fortescue, ii, 6.

4 Ibid., i, 576-578. 
In view of the fact that the practice of granting military pensions was well established in their home country in the eighteenth century, it was natural that the English colonists in America should provide for the relief and support of their soldiers injured in wars with the Indians or with the colonists of other nations. As early as 1624, while Sir Francis Wyatt was governor, the general assembly of Virginia passed a body of laws and orders which were sent to England for ratification by the courts of the Virginia Company. ${ }^{1}$ The thirty-second article in these laws was: "That at the beginning of July next the inhabitants of every corporation shall fall upon their adjoyning Salvages, as we did last year-Those that shall be hurte upon service to be cured at the publique charge; in case any be lamed to be maintained by the country according to his person and quality." Governor. Wyatt fell upon the savages during the summer of 1624, commanding in person an expedition against the Pamunkeys. $^{2} \quad$ However, the body of laws and orders from which the quotation has been made arrived in England too late for ratification. The king had required the Virginia Company to surrender its charter and had made the colony royal. Most of these laws were again passed by subsequent general assemblies. As to pensioning those hurt in fighting the Indians, the assembly voted in October, 1644: "Whereas in the late expeditions against the Indians, diverse men were hurt and maymed and disabled from provideing for their necessary maintenance and subsistance, $\mathrm{Be}$ it therefore enacted by the authority of this present Grand Assembly, That all hurt or maymed men be releived and provided for by the severall counties, where such men reside or inhabitt." 3 This plan of requiring the localities to care for disabled soldiers resident in them was similar to the system of relief in force in England under the act of 1640 and previous laws.

A. Virginia act for defense against the Indians passed in 1675

1 Hening's Statutes at Large, i, 121-129.

2 Alexander Brown, The First Republic in America, 606-607.

${ }^{3}$ Hening, i, 287. See also Hening, ii, 331, 347, 440 for other pension laws. 
provided "that due consideration shalbe had by the grand assembly of the indigent ffamilies of such as happen to be slaine, and of the persons and ffamilies of those who shalbe maimed and disabled in this warr." A similar law of June, 1676, provided that maimed and disabled soldiers should be "maintained by the publique by an annuall pension dureing their lives, and dureing the time of such their disabilitie." Other provisions of this kind for those wounded in the Indian Wars and in the French and Indian War might readily be cited.

Since the Virginia pension provision of 1624 did not receive the necessary ratification of the company in England, the Plymouth Colony should probably be credited with the earliest pension enactment in America. As early as 1636 the Pilgrims enacted in their court that "if any man shalbee sent forth as a souldier and shall return maimed hee shalbee majntained competently by the Collonie during his life." 1 This promise of relief was meant to encourage the colony's soldiers against the Pequod Indians who were then at war with the English settlers of New England. ${ }^{2}$

The general court of the Massachusetts Bay Colony appointed in 1676 a standing committee to consider the petitions of wounded soldiers for relief, and to report to the court what they judged meet to be done. In 1679 the general court ordered some wounded soldiers to apply to this committee for relief, its meetings being appointed for the second Tuesday in September and the second Tuesday in March in "Boston toune House." After the union of Massachusetts Bay and Plymouth by the charter of 1691, an act of November 23, 1693, was passed for the levying of soldiers. ${ }^{4}$ This law continued to disabled soldiers and seamen the yearly pensions allowed by the former government, and provided for the granting of relief out of the public treasury to such as might thereafter be disabled in the military

1 Plymouth Colony Records, xi, Laws, 106.

2 H. M. Sylvester, Indian Wars of New England, i, 183-339.

${ }^{3}$ Records of Colony of Massachusetts Bay, v, 80, 227.

- Acts and Rcsolies of Province of Massachusetts Bay, i, 135. 
service of the province. Substantially similar provisions are to be found in later military laws of the colony.

The colonial laws of Maryland also illustrate the way in which pensions were promised to disabled soldiers in order to encourage enlistment against the Indians. ${ }^{1}$ In April of 1661 the general assembly of Maryland met in session at St. Mary's. To the assembled delegates and burgesses of the two houses came reports that the Indians had lately killed some English on the Patapsco River. Steps were taken to authorize the raising of a body of able men to go against the Indians. Appropriately enough an act was brought before the assembly for the encouragement of such soldiers as should enlist for the defense of the country. It was enacted "that every person that shall adventure as a Souldier in any warre in the defence of the Country and shall therein happen to be maymed or receive hurt, shall according to his place and Quallity receive mayntenance from the Country according to his disabillity for mayntayning him selfe." This act was confirmed in Lord Baltimore's name in April, 1662, and in later records we find it referred to as "the perpetuall Law of this Province."

The Maryland militia law of November, 1678, contained unusually comprehensive pension provisions for a seventeenth century enactment. It promised the soldier who should be so injured while defending the province as to be rendered incapable of getting a livelihood a yearly pension out of the public levy of the province. This allowance was to be proportioned to, and for the time of, the disability. The act is especially worthy of note for its early and specific provision for the widows and orphans of the slain. It reads: "Every person Slaine in the service of this Province \& leaveing behind him a wife and Children such wife and Children shall alsoe be allowed a Competent pension the wife dureing her widdowhood and the Children till they be of yeares able to gett their Liveings or be putt out apprentices And that this pension shall be yearely Rated and

${ }^{1}$ Archives of Md., Proceedings of Assembly, 1637-38 to 1664, 408, 436 and also ibid., 1678-1683, 58. 
allowed out of the Publick Levy as aforesaid by a Generall assembly the party petitioning for such pension and allowance procureing a Certificate from the Commissioners of the County Court where he shee or they live that he she or they are Objects of Charity \& deserve to have such pension and allowance." In 1681 it was provided that these pensions should be paid out of the fifty thousand pounds of tobacco which was to be raised by public levy to defray the small charges of the province during the intervals between the meetings of the general assembly. In subsequent acts Maryland continued her liberal policy in the matter of military pensions.

New York, in the militia law passed May 6, 1691, provided that, "If any person upon any invasion or other publick military service be wounded or disabled he shall be cured and maintained out of the Publick Revenue."1 This was during the progress of King William's War. Later New York militia laws down to the time of the Revolution contained provisions similar to the above.

Early eighteenth century pension legislation in the colonies is illustrated by the Rhode Island law passed in 1718, a few years after the close of Queen Anne's War. ${ }^{2}$ For the comprehensiveness of its scope this measure will stand comparison with United States pension legislation of one hundred and fifty years later. The act provided that every officer, soldier, or sailor, employed in the colony's service, who should be disabled by loss of limb or otherwise from getting a livelihood for himself and family or other dependent relatives, should have his wounds carefully looked after and healed at the colony's charge, and should have an annual pension allowed him out of the general treasury, sufficient for the maintenance of himself and family, or other dependent relatives. In case a person who had the charge of maintaining a wife, children, or other relations should be slain in the colony's service, such relatives were to be maintained by a yearly pension in such amount as the general assembly should

1 Colonial Laws of Neze York, i, 234.

${ }^{2}$ Acts and Laws of Rhode Island, 74. 
deem sufficient "until such Wife, Children, Parents or other Relations shall happen to Die or be able to Subsist or Maintain themselves." The town council of each town in the colony was charged with the care and oversight of resident pensioners. Each council was from time to time to receive the pensions, and "therewith supply such persons as they shall stand in need thereof."

These examples of pension legislation in several of the American colonies aim to afford a fair idea of its scope and character and to show that much of colonial precedent and experience was back of the development of our great national pension system. Seeking to secure enlistments in military expeditions against the Indians, or against the French, the colonies promised to care for those who should be disabled and be left without means of obtaining a livelihood, and also to aid the indigent families of those who should fall in battle. It is to be noted that the disabled pensioner was required to be incapable of earning a livelihood. A wound or injury would not of itself entitle to a pension. Widows and dependent relatives were usually required to be in indigent circumstances, and in Maryland "objects of charity." Pension provisions came to be included commonly in acts organizing the militia or in levying soldiers for some particular military expedition. Rates of pension were not specifically fixed in the laws, that matter and other details being left to the process of administration. It is scarcely possible to ascertain the amount and adequacy of the relief afforded, though sundry references in the colonial records to pensioners and payments of pensions show that the laws must have been effective to a considerable degree.

By reason of so long an experience in caring for those wounded in the early wars against the Indians and French, the inhabitants of the colonies became familiar with the idea of military pensions, and it was natural that the continental government they formed should inaugurate a pension policy. Even before the Continental Congress had taken action, Virginia began to make provisions for pensions in acts to raise troops to oppose Governor Dunmore and to resist the injustice of En- 
gland. Nor during the Revolution did the states rely entirely upon Congress to provide for the relief of maimed and disabled soldiers. Some of them, notably Virginia and Pennsylvania, independently made liberal provision for the disabled and for the widows and orphans of the slain. In May, 1778, Virginia promised full pay during life to all of her soldiers in the Continental army who might be disabled in the service. In October of the same year, she enacted a law for the encouragement of Virginia officers and soldiers in the service of the United States, which promised half pay during life to the widows of those slain or dying in the service. In May, 1779, she anticipated by considerably over a year the action of Congress promising half pay for life to those officers who continued in service to the end of the war. ${ }^{1}$ Pennsylvania, by act of March 1, 1780, extended the half pay for seven years, granted by Congress to commissioned officers who served to the end of the war, to half pay for life, thus also anticipating the future action of Congress. Suitable provision was made in the same law for widows and orphans of those dying in battle, actual service, or captivity. ${ }^{2}$

1 Hening's Statutes at Large, ix, 14, 91, 456, 566; x, 25.

2 Laws of Pennsylvania, i, 488-489. 


\section{CHAPTER II}

\section{Revolutionary Pensions, 1776-1789}

During the progress of the Revolutionary War there were two principal aspects of the pension question that required the attention of Congress: first, the devising of a suitable invalidpension system for injured and disabled soldiers; second, action upon the persistent application of the Revolutionary army offcers for a grant of half pay service-pensions for life, to be paid, upon their retirement, to all officers who should serve to the end of the war.

The need of an invalid-pension system became apparent soon after the outbreak of hostilities. Applications for the relief of the wounded began to come before Congress, and temporary assistance was given in some individual cases. ${ }^{1}$ On June 2, 1776, Nathanael Greene, later selected as one of the major generals of the Revolutionary army, wrote to John Adams urging that provision be made for disabled officers and soldiers. Adams, who on June 13 became by choice of Congress chairman of the Board of War and Ordnance, replied to Greene on June 22 as follows: "Your reasoning to prove the equity and the policy of making provision for the unfortunate officer or soldier, is extremely just, and can not be answered; and I hope that when we get a little over the confusions arising from the revolutions which are now taking place in the colonies, and get an American Constitution formed, something will be done. I should be much obliged to you for your thoughts upon the subject. What pensions should be allowed, or what other provision made. Whether it would be expedient to establish a hospital, etc. It is a matter of importance, and the plan should be well digested." 2 Probably, by his query as to the expediency of establishing a hospital,

${ }_{1}^{1}$ W. C. Ford, Journals of the Continental Congress, v, 484, 489, 530, 601.

2 The Works of John Adams, ix, 402. 
Adams meant a home for invalid soldiers such as Chelsea Hospital in England rather than a hospital in the more modern sense.

Two days before Adams wrote to Greene, Congress had taken steps to have a plan for invalid-pensions prepared. A committee of five had been appointed "to consider what provision ought to be made for such as are wounded or disabled in the land or sea service, and report a plan for that purpose." Mr. Robert Treat Paine, a colleague of Adams from Massachusetts, was made chairman of this committee. The other members were Mr. Francis Lightfoot Lee of Virginia, Mr. Lyman Hall, of Georgia, Mr. William Ellery of Rhode Island, and Mr. Francis Lewis of New York. ${ }^{1}$ It will be noted that four of the five members of the committee came from colonies whose pension legislation was illustrated in the last chapter. Thus preparation was being made for a continental pension provision even before the Declaration of Independence. The plan submitted by this committee was adopted by Congress August 26, 1776, and became the first national pension law in the United States. ${ }^{2}$ This act promised half pay for life or during disability to every officer, soldier, or sailor losing a limb in any engagement or being so disabled in the service of the United States as to render him incapable of earning a livelihood. Proportionate relief was promised to such as were only partially disabled from getting a livelihood. It was recommended to the states to appoint proper officers for the execution of the law, and the several legislatures were requested to cause the payment on account of the United States of such half pay and other allowances as should be adjudged due to the soldiers of their respective states.

In one interesting feature, the plan that was adopted directly followed British precedent. It provided that pensioned officers and soldiers, capable of doing guard or garrison duty, should be formed into a corps of invalids and subjected to such duty. Naval pensioners were also made liable to such duties as they might be able to perform aboard the navy or in any department

1 Ford, Journals of the Continental Congress, v, 469 (June 20, 1776).

2 Ibid., v, 702-705. 
thereof. An invalid corps was actually established in 1777 with Lewis Nicola, formerly an officer in the British army, as colonel. This corps was intended to do garrison duty, to serve as a military school for young gentlemen, and to be employed in the recruiting service. The proposed strength of the corps was eight companies, containing about a thousand officers and men. Invalids, when engaged in this service, were entitled to full pay, and companies were raised from time to time. ${ }^{1}$

This inauguration of a national pension system in 1776 was a lcgical development from British and colonial precedent and experience. Doubtless members of the committee that framed the law were familiar with legislation in their colonies on the subject. Just as was the case with the colonial pension enactments, the national measure aimed to encourage enlistments in the army. But the scant resources and power of the Continental Congress made it necessary to entrust the execution of the plan to the states. Consequently, the continental pension provision was just as effective as the individual states chose to make it, and in many instances they performed the administrative duties assigned to them very imperfectly.

On September 25, 1778, Congress again dealt with the matter of invalid-pensions. ${ }^{2}$ The relief provided by the law of 1776 was extended to those who had been disabled before that date and since the commencement of hostilities on April 19, 1775 (the battle of Lexington and Concord). All who had fought for the common defense, even on emergency call, were embraced within the scope of the invalid-pension system by the resolutions of 1778 , and methods of proving claims were permitted other than those contained in the resolves of 1776 .

During the progress of the war further provision for invalids was made by the act of April 23,1782. ${ }^{3}$ By the terms of this measure, all sick or wounded soldiers, unfit for duty either in 690.

1 Ford, Journals of the Continental Congress, vii, 288; viii, 485, 554, 585,

2 Ibid., xii, 953.

3 Ibid., xxii, 210. 
the field or in garrison and applying for a discharge in preference to being placed or continued in the corps of invalids, were entitled to be discharged and to receive as a pension five dollars per month in lieu of all pay and emoluments. It was recommended to the several states to pay such pensions annually and to draw upon the superintendent of finance for the money advanced.

When peace had been established and the army disbanded, the matter of invalid-pensions again demanded the attention of Congress. The resolutions of June 7,1785 , recommended to the several states a uniform method of providing for the pensioners. ${ }^{1}$ Commissioned officers, when disabled so as to be wholly incapable of earning a livelihood, were to be allowed a half pay pension. For noncommissioned officers or privates, the full pension rate was fixed at five dollars a month with a proportionate allowance for a partial disability. No officer who had accepted his commutation for half pay (see pages 41,49 ) was to be entered on the list of invalids, unless the commutation was first returned. The plan of administration required each state to appoint officers to examine the evidence of claimants, admit claims, and make the pension payments. Amounts so expended were to be deducted from the quotas of money paid by the respective states for the support of the Confederation. It was also made the duty of the state authorities to transmit annually complete lists of the invalid-pensioners of the United States in each state to the office of the Secretary of War, with information as to the pay, age, service, and disability of each invalid.

The final resolutions of the Congress of the Confederation on the subject of invalid-pensions were passed on June 11, 1788. ${ }^{2}$ They contained a provision: "That no person shall be entitled to a pension as an invalid who has not, [sic] or shall not before the expiration of six months from this time, make application therefor, and produce the requisite certificates and evidence to entitle him thereto." Had this limitation been kept in force and

1 Journals of Congress (Washington, 1823), iv, 534-535.

2 Ibid., iv, 821. 
service-pensions not been introduced, the burden of the Revolutionary pension list would have been light. When in 1792 the limitation was suspended by the federal Congress, there were about 1,500 invalid-pensioners on the rolls. ${ }^{1}$ On the average, the annual cost of the list was considerably less than one hundred thousand dollars. During the war and under the Confederation, the states were entrusted with the administration of the laws for the relief of invalids. ${ }^{2}$ Some of them failed to act. Consequently Congress, after the inauguration of the federal government, undertook in 1790 the payment to invalid-pensioners of the amounts left in arrears by the states. ${ }^{3}$

The second phase of pension legislation during the Revolution-the officers' half pay movement-commanded the attention of Congress and the people far more than the establishment of an invalid-pension system. ${ }^{4}$ Upon retirement from active service, British officers were entitled to be placed upon half pay. This fact seems to have suggested the plea of the American officers for a grant of half pay for life to all officers who should continue in the Revolutionary army until the end of the war. Serving under discouraging conditions and with pay and other allowances in arrears, the officers asked Congress to promise them a retirement pension for life as a recognition of steadfast devotion to the cause until independence should be finally won. But the proposition was unpopular and aroused great controversy and opposition. Although Congress at last gave the desired promise, there was at the close of the war widespread and bitter resistance to measures of fulfilment. The matter of the officers' half pay was long drawn out before final settlement, but

\footnotetext{
${ }^{1}$ Reports of Secretary Knox, American State Papers, Claims, 5, 8, 18, $28,57$.

2 Descriptive lists of invalids, with the amounts paid, were transmitted to the War Office by New Hampshire, Massachusetts, Connecticut, New York, New Jersey, Pennsylvania and Virginia. See report of a committee on the department of war, October 2, 1788. Journals of Congress (1823 edition), iv, 873.

3 U. S. Statutes at Large, vi, 4.

4 A valuable monograph containing information regarding the officers' half pay movement is L. C. Hatch, The Administration of the American Revolutionary Army, 79-85.
} 


\section{FEDERAL MILITARY PENSIONS IN THE UNITED STATES}

its history is of value because of the important persons and critical situations involved.

The story begins with the closing months of 1777 , when the condition of Washington's army was most distressing and discontent among the officers was great. In November, 1777, a paper making proposals for the benefit of the officers was presented to Washington by Colonel Theodoric Bland, an officer who had been educated in England and Scotland. There exists in Washington's handwriting a manuscript containing some "remarks" on Bland's paper. Among other things he wrote: "The allowance of land to the disbanded officers may be proper enough -but will not half pay be attended with enormous expence? and would not this, and allowing half pay to the officers of reduced regiments at the end of the war, add such weight to a debt already, [sic] and probably will be, of such magnitude, as to sink the colonies under the load of it; and give a great disgust to the people at large?"1 The date of these "remarks" is uncertain, but they indicate that the proposed half pay for life, when first broached, impressed Washington unfavorably. However, as will appear, he soon became a strong supporter of the measure.

On November 28, 1777, Congress appointed a committee to visit the army and to consult with General Washington as to means for carrying on a winter's campaign with vigor and success. $^{2}$ They found the army badly clothed, ill-furnished with supplies, and the officers averse to attacking the enemy. On December 16 they reported in favor of the army taking an advantageous post until sufficient reinforcements could be obtained to make an attack. ${ }^{3}$ This policy was not satisfactory to those who wanted a vigorous campaign, and there was a remonstrance from the executive council and assembly of Pennsylvania. The army took post at Valley Forge, from which place Washington wrote on December 23, 1777, to the President of Congress, giving a

1 W. C. Ford, Writings of Washington, vi, 384-5, note.

2 Ford, Journals of the Continental Congress. ix, 972.

3 Ibid., ix, 1029. 
detailed account of the distressing condition of his army and replying in strong terms to the remonstrance of the Pennsylvania legislature. ${ }^{1}$ In this letter he showed that he had come to feel that the half pay ought to be promised. He spoke of "the necessity of some better provision for binding the officers by the tie of interest to the service, as no day nor scarce an hour passes without the offer of a resigned commission; (otherwise I much doubt the practicability of holding the army much longer together, and in this I shall probably be thought the more sincere, when I freely declare, that I do not myself expect to derive the smallest benefit from any establishment that Congress may adopt, otherwise than as a member of the community at large in the good, which I am persuaded will result from the measure, by making better officers and better troops)."

On December 24 a new committee, consisting of Elbridge Gerry, Jonathan Bayard Smith, and John Witherspoon, was appointed to take army affairs into consideration. ${ }^{2}$ This committee made a report on January 5, 1778, and placed before Congress the proposition to allow half pay for life, at the conclusion of the war, to all officers who should continue in service until the end. ${ }^{3}$ The plan included a proviso that such officers might be called into service again when necessary. It was also proposed that, under regulations to be made by Congress, the commissions of officers might be transferable in time of peace. These details were evidently influenced by the practice in England. In case officers should lose their lives in service the report proposed that widows might receive the one - part of an officer's pay. The plan also called for a Pension Office, with a commissioner and two clerks, to be opened and kept in the place where Congress should hold its sessions.

This service-pension plan for the Revolutionary officers, and modifications growing out of it, occupied much of the attention of Congress for years. Its unpopularity is shown by the persis-

1 Ford, Writings of Washington, vi, 257-265.

${ }^{2}$ Ford, Journals of the Continental Congress, ix, 1052-3.

${ }^{3}$ Ibid., $\mathrm{x}, 18-20$. 
tent opposition which caused it to be postponed from time to time. Elbridge Gerry, the chairman of the committee that reported the plan, professed himself to be personally well disposed toward it. But, on January 13, 1778, he wrote to Washington that the principal objections to the measure were: "the infant state of the country, its aversion to placemen and pensioners, whereby Great Britain is likely to lose her liberty, the equality of the officers and soldiers of some states, before the war, and the bad effect that such provision would have on the minds of the latter."

Early in January Congress discussed the report of Gerry's committee, which had been referred to the committee of the whole. Another committee was sent to camp with comprehensive instructions to form plans for improving the condition and efficiency of the army. ${ }^{2}$ Washington had by this time become a strong advocate of the "half pay and pensionary establishment" and, on January 28, he wrote for the benefit of this new committee a memorial in which he reviewed the existing gloomy state of the army and suggested changes he thought essential. In this letter he said that, on the part of the officers, there were frequent resignations, and more frequent importunities for permission to resign, and, in the ranks, "apathy, inattention and neglect of duty." To reanimate the languishing zeal of the officers, he urged upon Congress a provision for half pay and pensions. "This," he said, "would not only dispel the apprehension of personal distress, (at) the termination of the war, from having thrown thcmselves (out) of professions and employments they might not have it in (their) power to resume; but would in a great degree relieve the painful anticipation of leaving their widows and orphans, a burthen on the charity of their country, should it be their lot to fall in its defence." Again on March 24 Washington wrote the President of Congress: "As it is not improper for Congress to have some idea of the present

1 Sparks, Correspondence of the Revolution, ii, 67.

2 Ford, Journals of the Continental Congress, x, 24, 37, 39-41, 67.

${ }^{3}$ Ford, Writings of Washington, vi, 301-304. 
temper of the army, it may not be amiss to remark in this place, that, since the month of August last, between two and three hundred officers have resigned their commissions, and many others were with difficulty dissuaded from it. In the Virginia line only, not less than six colonels, as good as any in the service, have left it lately; and, more, I am told, are in the humor to do so."1

On March 26 two of the committee returned from the camp and offered new resolutions promising half pay for life to officers who should serve to the end of the war and not hold an office of profit under the United States or any of them. ${ }^{2}$ Officers' commissions were to be transferable, and a purchaser was to be entitled to receive the half pay during the life of the original holder of the commission. It was also provided that the widow of an officer killed in service should receive the half pay which her husband might have received. The modified plan met no friendlier reception than the similar proposition in January. It was debated at length in committee of the whole from day to day, and on April 2 the matter was postponed. ${ }^{3}$

Washington again wrote to the President of Congress on April 10, arguing warmly and at length for the half pay establishment. "I do most religiously believe," said he, that "the salvation of the cause depends upon it, and, without it, your officers will moulder to nothing, or be composed of low and illiterate men, void of capacity for this or any other business." He asserted that he had no personal interest in the decision as he would not receive the smallest benefit from the half pay establishment. But, as a citizen desiring the success of the army, he was deeply interested. ${ }^{4}$

On April 16 Congress resumed consideration of the subject of an allowance to officers after the war. Parts of Washington's letters dealing with the matter were called for and read. ${ }^{5}$

1 Ford, Writings of Washington, vi, 445.

2 Ford, Journals of the Continental Congress, $x, 285-6$.

${ }^{3}$ Ibid., x, 302.

4 Ford, Writings of Washington, vi, 466.

5 Ford, Journals of the Continental Congress, $\mathrm{x}, 341,357-360$. 
The opponents of the plan under consideration proposed to postpone action and to ask the states to give their opinion whether a provision ought not to be made for the officers of the continental army after the conclusion of the war, whether that provision should be for life or for a term of years, whether any provision should be made for widows of the fallen, and whether some further compensation or reward ought not to be granted to the privates who continue in the continental army to the close of the war. This proposal was defeated. Laurens, the President of Congress, wrote on April 19 to Governor Livingston of New Jersey that whole days and tedious nights had been spent in hammering upon the plan, but that "all our labor has not yet matured one single clause, nor even determined the leading questions, to be or not to be."

As the discussion proceeded, there was a majority in favor of making some provision for the officers after the war but great difficulty in agreeing upon details. ${ }^{2}$ On April 21 Washington wrote from Valley Forge to John Banister, delegate in Congress from Virginia, "I am pleased to find, that you expect the proposed establishment of the army will succeed; though it is a painful consideration, that matters of such pressing importance and obvious necessity meet with so much difficulty and delay. $\mathrm{Be}$ assured, the success of the measure is a matter of the most serious moment, and that it ought to be brought to a conclusion as speedily as possible." In a long and bloody war, Washington thought that patriotism might accomplish much but that it would not endure unassisted by interest. $\mathrm{He}$ also compared the disadvantages of the American service with the advantages of that of the enemy. ${ }^{3}$

There were many prominent men, however, taking the other side of the controversy. On April 27 Governor Livingston of New Jersey wrote: "But in my private judgment, I should be totally against the plan of allowing the officers half pay after

1 Sedgwick, Livingston, 272.

2 Ford, Journals of the Continental Congress, x, 362, 372-4.

${ }^{3}$ Ford, Writings of Washington, vi, 477-9. 
the war. It is a very pernicious precedent in republican states; will load us with an immense debt, and render the pensioners themselves in a great measure useless to their country. If they must have a compensation, I think they had better have a sum certain to enable them to enter into business, and become serviceable to the community." 1 Laurens, the President of Congress, thought the half pay proposition unjust because not according to the compact. He pointed out that officers had solicited commissions eagerly, knowing the terms of service. He even went so far as to say in a letter to Washington on May 5: "If we can not make justice one of the pillars, necessity may be submitted to at present; but republicans will, at a proper time, withdraw a grant which will appear to have been extorted." ${ }^{2}$ This prediction that the grant would be withdrawn, if made, is significant in view of the actual course of events at the conclusion of the war.

The discussion in Congress had resulted in a vote on April 26 by six states to five, with one divided, that the provision to be made for the officers should be half pay for life. ${ }^{3}$ But the very next day a proviso was added that the United States might at any time redeem the half pay of such officers as they thought proper by paying them a sum equal to six years' half pay. ${ }^{4}$ Then the further consideration of the whole matter was postponed, and it was not taken up again until May 8, when an amendment to exclude foreign officers in the United States service from the half pay was defeated. ${ }^{5}$ Discussion continued from time to time until May 15. Then a compromise proposition was offered by general consent as an amendment to take the place of the whole report under consideration. ${ }^{6}$ This compromise was carried by unanimous vote, eleven states voting. However, Mr. Lovell voted "no" in the Massachusetts delegation and Mr. Wolcott "no" in that of Connecticut. The compromise provided that

${ }^{1}$ Sedgwick, Livingston, 281.

2 Sparks, Correspondence of the Revolution, ii, 119-121.

3 Ford, Journals of the Continental Congress, $x, 394-7$.

4 Ibid., x, 398.

Ibid., xi, 482-3.

'Ibid', xi, 502-3. 
officers who served until the end of the war should receive half pay for seven years after its conclusion. This allowance was not to exceed the half pay of a colonel and was not to extend to those holding offices of profit under the United States or any of them. Nor was it to be given to officers who had not taken an oath of allegiance to, and actually resided within, the United States. Noncommissioned officers and privates who should serve to the end of the war were promised a further reward of eighty dollars at its termination. Thus the long struggle over the matter seemed to have reached a conclusion, but the officers were not entirely satisfied, and the settlement did not.prove to be final.

The compromise measure was well received by Washington. He wrote to Gouverneur Morris from Valley Forge on May 18: "Your favor of the 15th instant gave me singular pleasure. I thank you for the agreeable intelligence it contains, which, though not equal to my wishes, exceeded my expectations; and is to be lamented only for the delay." 1 And on the same day, Washington wrote to the President of Congress: "I shall announce the resolution of the 15th to the army, and would flatter myself it will quiet in a great measure the uneasinesses, which have been so extremely distressing, and prevent resignations, which had proceeded, and were likely to be at such a height, as to destroy our whole military system. It has experienced no inconsiderable shock, particularly in the line of some states, from the loss of several very valuable officers."

It is not too much to say that the measure of May 15, 1778, was wrung from an unwilling Congress by the fear that the army would go to pieces. It did not, however, relieve present distress nor put an end to discontent. On January 20. 1779, Washington wrote to a committee of Congress reviving the matter of the half pay for life "not without great reluctance." $\mathrm{He}$ argued: "The difference indeed in point of expense, between the present form of the half pay establishment. and one for life, would be inconsiderable. Seven years will probably be the

1 Ford, Writings of Washington, vii, 16.

2 Ibid., vii, 20. 
period of the lives of the greatest part of the incumbents, and few of the survivors will much exceed it. But the difference in the provision in the estimation of the officer's own mind is very great. In one case he has a provision for life, whether it be long or short; in the other, for a limited period, which he can look beyond, and naturally flatters himself he shall outlive." The commander-in-chief also pointed out the encouragement to a married man in providing pensions for officers' widows and the discouraging effect of the reverse policy. "The chief objection," continued he, "which I have heard to this plan, is, that the principle of pensioning is incompatible with the maxims of our government. The truth of this objection I shall not controvert, but I think it applies equally to an establishment for seven years, as to one for life. It is alike a pension in both cases, in one for a fixed and determinate, in the other for a contingent period. All that can be said is, that we submit to one inconvenience to avoid a greater; and, if it operates as a bad precedent, we must endeavor to correct it when we have it in our power."1

Washington's arguments produced no immediate results, and the "discontents and distresses" of the army officers continued. On May 8, writing to Gouverneur Morris, Washington said: "Our army, as it now stands, is but little more than the skeleton of an army; and I hear of no steps that are taking to give it strength and substance. I hope there may not be great mistakes on this head, and that our abilities in general are not overrated. The applications for succor are numerous, but no pains are taken to put it in my power to afford them." 2 To John Armstrong, on May 18, he wrote: "The cries of the distressed, of the fatherless and widows, come to me from all quarters. . . . Officers, unable any longer to support themselves in the army, are resigning continually, or doing what is worse, spreading discontent, and possibly the seeds of sedition." After alluding to the confidential character of his letter, he said: "I have never yet

1 Ford, Writings of Washington, vii, 328-335.

2 Ibid., 449-452. 
seen the time in which our affairs (in my opinion) were at so low an ebb as they are at present."' On May 24 Morris moved in Congress to extend the half pay for seven years to half pay for life, but the motion was declared out of order by a unanimous vote of the states. ${ }^{2}$

However, during the summer of 1779 Congress had a further provision for the officers of the army under consideration, and a committee prepared a report on the matter. ${ }^{3}$ This report favored a grant of half pay for life and provided for allowing the half pay of officers who should die in service to their widows during widowhood. On August 17 Congress took a vote favorable to the half pay for life, but immediately afterward it receded from this position. A recommendation was then made to the states to provide further for the officers and soldiers enlisted for the war and for the widows of officers and soldiers so enlisted who should die in service. ${ }^{4}$ The officers continued to urge their claims upon Congress, and on November 18 a memorial from the general officers of the army asking for further allowances was presented. Again on December 1 there was a report presented favoring the grant of the half pay for life, and again was action deferred. ${ }^{5}$

Repeated discouragements did not put an end to the applications by the officers. In July, 1780, the general officers prepared a memorial which was read in Congress August 3 and referred to a committee of six headed by Roger Sherman. ${ }^{8}$ This committee's report on August 12 contained a proposition to extend half pay to the widows of deceased officers. The proposition was recommitted. ${ }^{7}$ In a letter written to Joseph Jones, a member of the committee, on August 13, Washington spoke of the distressing conditions among the officers. He said that no

1 Ford, Writings of Washington, vii, 454-458.

2 Ford, Journals of the Continental Congress, xiv, 638-640.

${ }^{3}$ Ibid., xiv, 826, 908, 946 (report printed), 952, 971, 973, 977.

4 Ibid., xiv, 973.

Ibid., xv, 1286, 1335-1336.

6 Ibid., xvii, 689.

7 Ibid., xvii, 726. 
officer could live upon his pay, that numbers were unfit for duty for want of clothing, and that hundreds had resigned because they could no longer support themselves as officers. ${ }^{1}$ On August 20 Washington wrote to the President of Congress speaking of the complaints which arose from the inequality of the provisions made for the officers by the several states. Pennsylvania had made a decent provision for her officers by giving them half pay for life, while the lines of some other states were so destitute as to be unfit for duty for lack of clothing. Washington again urged upon Congress the half pay provision as "the most politic and effectual that can be adopted."2

Congress could not yet be persuaded to promise the half pay for life. But, on August 24, 1780, the report of the committee on the memorial of the general officers was again taken up, and favorable consideration was given to the claims of the widows and orphans of officers. In 1778 Congress had promised seven years' half pay to officers serving to the end of the war. Now a resolution was adopted granting half pay for the same length of time to the widows of those officers who had died, or should thereafter die, in the service. The half pay was to commence from the time of an officer's death. If there were no widow surviving, or in case of her death or remarriage, the half pay was to go to any orphan children of the deceased. The legislatures of the respective states were asked to make the necessary payments on account of the United States. This was the first national pension law for the benefit of widows and orphans. ${ }^{3}$ Although Congress did not at this time fully meet the wishes of the officers, it made other concessions such as the repeal of the proviso that a recipient of the seven years' half pay should "not hold office of profit under these states, or any of them."

1 Ford, Writings of Washington, viii, 379-380.

2 Ibid., viii, 398.

3 Hunt, Journals of the Continental Congress, xvii, 770-773. After the adoption of the federal Constitution, resolutions of Congress of November 2,1785 , and July 23,1787 , were construed as barring further claims under the resolution of August 24, 1780. Section 1 of the act of March 23, 1792, suspended the barring resolutions for two years. U.S. Statutes at Large, i, 243. 


\section{FEDERAL MILITARY PENSIONS IN THE UNITED STATES}

That dogged persistence was an element in Washington's character is shown by the fact that he returned to the subject of half pay for life in a letter addressed to the President of Congress on October 11." "Supported by a prospect of a permanent independence," said he, "the officers would be tied to the Service, and would submit to many momentary privations, and to the inconveniences, which the situation of public affairs makes unavoidable. This is exemplified in the Pennsylvania officers, who, being upon this establishment, are so much interested in the Service, that, in the course of five months there has been only one resignation in that line." Referring to the objection that such a provision was wanting in some foreign armies, Washington said: "The Military profession holds the first rank in most of the Countries of Europe, and is the road to honor and emolument. The establishment is permanent, and whatever be an officer's provision, it is for life, and he has a profession for life. - . Pensions, distinctions, and particular privileges, are commonly his rewards in retirement. In the case of the American officers, the military character has been suddenly taken up, and is to end with the war."

Washington's letter was referred to the same committee of Congress which had his letter of August 20 under consideration. On October 20 the committee reported, and on October 21 Congress at last complied with Washington's repeated solicitations by passing the following resolution: "That the officers who shall continue in the service to the end of the war, shall also be entitled to half pay during life, to commence from the time of their reduction." 2 This clause of the report, which had been so persistently and vigorously opposed, was carried by nine states to three, Massachusetts, Connecticut, and New Jersey voting in the negative. The complete report of the committee, including the above provision, was adopted by eight states to four, Rhode Island joining the negative. Some doubt having arisen as to whether the resolution of October 21 applied to all the general

1 Ford, Writings of Washington, viii, 481-493.

2 Hunt, Journals of the Continental Congress, xviii, 958. 
officers, Congress on November 28, 1780, voted that the half pay for life was meant to extend to major generals and brigadier generals. ${ }^{1}$

Without resources to relieve the immediate distress of the officers, Congress had finally been brought to yield to their demands for a reward at the end of the war and for the remainder of their lives. It seemed better to risk offending some of the states than to take the chance that the army might be dissolved. But, after all, the fulfilment of the promise that had been made depended on the attitude of the states.

As the conclusion of hostilities approached, the popular feeling against the half pay for life grew, in New England especially, into a clamor of opposition. The officers began to fear that they would never obtain their promised reward. The situation was such as Laurens, President of Congress, must have anticipated, when he spoke in 1778 of the possibility of withdrawing "a grant which will appear to have been extorted."2

The Massachusetts officers, distrusting the ability of Congress to get funds for the half pay, applied to the legislature of their own state for a guarantee of the half pay or for commutation by the payment of a sum in gross in lieu of the annuity for life. $^{3} \quad$ Though they found influential support, the lower house was hostile to their plea and they were unsuccessful. Samuel Osgood, an influential member of the Massachusetts delegation to Congress, took the position that the matter should be dealt with by Congress and that Massachusetts ought not to make special provision for her own officers.

Though Osgood held that the officers should apply to Congress, General Lincoln, the Secretary of War, did not think well of their prospects of a settlement from that authority. He gave

1 Hunt, Journals of the Continental Congress, xviii, 1100.

2 Sparks, Correspondence of the Revolution, ii, 120.

3 They prepared a petition to the general court of Massachusetts in July, 1782 , and sent a committee of officers of high rank to present their memorial at Boston in September, 1782. A detailed account of the application by the Massachusetts officers to their own state is given in Hatch, The Administration of the Revolutionary Army, 143-150. 
it as his opinion, in a private letter to Washington dated October 14,1782 , that the matter of the half pay would not be in a better situation "until it shall be recommended by Congress to the several states to provide for their own officers." The half pay, he said, had been agreed upon by less than nine states before the Articles of Confederation were in force, and he did not think that nine states would vote for it now. ${ }^{1}$

Washington's correspondence of the period shows how critical conditions were in the army. ${ }^{2}$ About the middle of December, he wrote to Joseph Jones that dissatisfaction had arisen to a great and alarming height, and that combinations among the officers to resign at given periods in a body were beginning to take place. He said that by some address and management the resolutions of the officers had been converted into the form of a memorial which would be presented to Congress. ${ }^{3}$

The Massachusetts officers took the lead in preparing the statement of their grievances and desires for Congress and invited the officers of several other states to join them. ${ }^{4}$ In their address complaint was made that there had been no effectual provision for the half pay and that those entitled to it had become the objects of obloquy. ${ }^{5}$ The grant seemed to them an honorable and just recompense for years of hard service in which they had suffered in health and fortune. If the objection were against the mode of reward only, they offered in the interest of harmony to commute the half pay pledged for full pay during a term of years, or for a sum in gross. Congress was also asked to make proper provision for disabled officers and soldiers, and for the widows and orphans of those who had lost their lives in the service of their country.

A committee of three, Major General McDougall of New

1 Sparks, Writings of Washington, viii, footnote, 356-7.

2 To the Secretary of War (General Lincoln), Oct. 2, 1782, Ford, Writings of Washington, $\mathrm{x}, 90$; to James McHenry, Oct. 17, 1782, ibid., $\mathrm{x}, 94$; to Joseph Jones, Dec. 14, 1782, ibid., x, 117.

3 Ibid., x, 117-9.

"Hatch, The Administration of the Revolutionary Army, 147-9.

- The full text of the memorial is printed in connection with the proceedings of Congress, April 29,1783. Journals of Congress (1823 edition), 206-215. 
York, Lieutenant Colonel Brooks of Massachusetts, and Colonel Ogden of New Jersey, were chosen to represent the officers before Congress. The committee, after suffering considerable delay, proceeded to Philadelphia and presented the memorial on January $6,1783 .^{1}$ Washington, in writing to Joseph Jones on December 14, had advised "soothing measures" towards the officers in the very critical state of affairs. ${ }^{2}$ Their paper was accordingly received and referred to a "grand committee"-a committee having one member from each state-_"as a mark," says Madison, "of the important light in which the memorial was viewed." The grand committee, on the evening of January 13 , gave an audience to the representatives from the army. ${ }^{3}$ The officers on that occasion dwelt particularly upon three points-an instalment on the pay due, security for the arrears, and provision for the half pay for life. They expressed dissatisfaction with the states which opposed the half pay, observing that it formed part of the wages stipulated to them by Congress. "They complained that this part of their reward had been industriously and artfully stigmatized in many states with the name of pension, although it was as reasonable that those who had lent their blood and services to the public should receive an annuity thereon, as those who had lent their money." They referred to their memorial "to show that they were authorized and ready to commute their half pay for any equivalent and less exceptionable provision."

After the departure of the representatives of the army, the grand committee appointed a subcommittee consisting of Hamilton, Madison, and Rutledge to report arrangements in concert with Morris, the Superintendent of Finance. On January 24 the grand committee presented to Congress a report drawn by Hamilton of the subcommittee. With regard to the officers' half pay, the report favored leaving it "to the option of all officers

${ }^{1}$ Hunt, Writings of James Madison, i, 303.

2 Ford, Writings of Washington, $\mathbf{x}, 118$.

${ }^{3}$ For the whole discussion of the officers' memorial, see Madison's report of the "Debates in the Congress of the Confederation," Hunt, Writings of James Madison, i, 250 and following. 
entitled to half pay, either to preserve their claim to that provision as it now stands by the several resolutions of Congress upon that subject, or to accept —— years' full pay, to be paid to them within one year after the conclusion of the war, in money, or placed upon good funded security, bearing an annual interest at six per cent." The following day Congress debated this proposition for the commutation of the half pay for life, but could not agree as to what number of years' full pay should be allowed. It was, in fact, very doubtful whether the New England states would concur in any arrangement of the sort "so averse were they to what they called pensions." Estimates were made that the annual amount of half pay was between four and five hundred thousand dollars, and that the interest on the proposed commutation would be nearly two-thirds of that sum. The prospective expense impressed Congress with the need of caution, and the report was referred to a new committee of five headed by Osgood of Massachusetts. ${ }^{1}$

When the proposal to commute the half pay was again taken up on February 4, the delegates from Connecticut and Rhode Island said that they were bound by instructions to oppose this method of settlement. They questioned the validity of the promise of half pay, "as it had passed before the Confederation, and by a vote of less than seven [sic] states." " Madison and Bland of Virginia, and Wilson of Pennsylvania, held that the grant was valid because it was made according to the rule then in force. Surprise was expressed by Wilson that instructions should be given which militated against the most peremptory and lawful engagements of Congress. If such a doctrine prevailed, he said that the authority of the Confederacy was at an end. By general consent, the report lay over. ${ }^{3}$

In view of the unwillingness of Connecticut and Rhode Island, in particular, to honor recommendations or requisitions of Congress for the half pay, and in view of the fact that Congress had

1 Hunt, Writings of James Madison, i, 324, 327.

2 See page 34 , ante.

${ }^{3}$ Hunt, Writings of James Madison, i, 357. 
no fund available, Gilman of New Hampshire moved on February 25 that the officers of the army be referred to their respective states for their half pay. It was claimed that such action would be satisfactory to the officers. In the debate, Wolcott of Connecticut went so far as to say that "the states would give Congress nothing whatever, unless they were gratified in this particular." Not only was Rhode Island unwilling to meet requisitions of Congress for the half pay, but Collins said that she had expressly instructed her delegates to oppose every measure tending to an execution of the promise out of moneys under the disposition of Congress. To such statements the reply was made that the half pay was a debt as solemnly contracted as any other debt, and that the states could not refuse a requisition for the purpose of making a settlement. A reference of the officers to their own states would not, it was said, be satisfactory to the officers of the states that objected to half pay, and such a mode of settlement was not in accordance with the law of the Confederation. Gilman's motion was defeated.

When the debate was resumed on February 27, Madison pointed out "that the commutation proposed was introduced as a compromise with those to whom the idea of pensions was obnoxious, and observed, that those whose scruples had been relieved by it had rendered it no less obnoxious than before, by stigmatizing it with the name of a perpetuity. $\mathrm{He}$ said, the public situation was truly deplorable. If the payment of the capital of the public debts was suggested, it was said, and truly said, to be impossible; if funding them and paying the interest was proposed, it was exclaimed against as establishing a dangerous moneyed interest, as corrupting the public manners, as administering poison to our republican constitutions." 1 On the next day, there were seven ayes in favor of a motion to grant five years' full pay as commutation, but the proposition was held to be an appropriation requiring nine votes.

On March 10 a plan for the commutation of the half pay was

${ }^{1}$ Hunt, Writings of James Madison, i, 392. 
again discussed in Congress and received the votes of eight states. The whole Massachusetts delegation voted "aye." Connecticut was divided, and New Hampshire, Rhode Island and New Jersey voted "no."

While Congress was debating and postponing, matters were going from bad to worse in the army. About March 10 appeared the well known "Newburgh addresses," urging the officers of the army not to separate until Congress had done justice to their claims. Washington transmitted copies of these addresses to Congress, accompanied by official and private letters, detailing the occurrences at the Newburgh encampment. ${ }^{2}$ His letter of March 12 was placed before Congress on March 17. Madison's interesting report of the proceedings tells how the difficulties of the situation were placed upon the shoulders of those who were opposing the commutation and other settlements. He says: "By private letters from the army, and other circumstances, there appeared good ground for suspecting that the civil creditors were intriguing, in order to inflame the army into such desperation as would produce a general provision for public debts. These papers (Washington's letter and the anonymous addresses) were committed to Mr. Gilman, Mr. Dyer, Mr. Clark, Mr. Rutledge, and Mr. Mercer. The appointment of these gentlemen was brought about by a few members, who wished to saddle with this embarrassment the men who had opposed the measures necessary for satisfying the army, viz., the half pay and permanent funds; against one or other of which the individuals in question had voted.", In his account of the proceedings, Madison also says that the alarming intelligence from the army, the critical situation of American affairs in Europe, and the financial difficulties at home gave peculiar awe and solemnity to the moment and "oppressed the minds of Congress with an

${ }^{1}$ Journals of Congress, iv, 173 (1823 edition).

2 To the President of Congress, March 12, 1783; to Joseph Jones in Congress, March 12,1783; to the President of Congress, March 18, 1783; to Joseph Jones, March 18, 1783. Ford, Writings of Washington, x, 168, 174, 178,182 .

s Hunt, Writings of James Madison, i, 407. 
anxiety and distress which had been scarcely felt in any period of the Revolution."

The plan to impress with the perils of the situation the members who had opposed commutation and other settlements with the army was successful. By his negative vote on March 10, Dyer of Connecticut had prevented a proposition for commutation from receiving the vote of nine states and thereby being adopted. On March 20 he offered a plan of commutation substantially the same as that which had been defeated. Madison observes that: "This seemed to be extorted from him by the critical state of our affairs, himself personally, and his state, being opposed to it."

On March 22 Congress received a letter from Washington (dated March 18) in which he related the fortunate outcome of a convention of the officers and urged that their sacrifices and sufferings should be rewarded by a provision for the half pay in addition to the simple payment of their wages. ${ }^{1}$ On the same day Dyer's proposal for commutation was agreed to. However, he insisted on a preamble intended to reconcile his state of Connecticut to the measure. Nine states voted "aye," including the four delegates of Massachusetts, and Wolcott and Dyer for Connecticut. $^{2}$

The Commutation Act, as the new measure was termed, provided that in lieu of the half pay for life the officers should receive five years' full pay, in money, or in securities bearing interest at six per cent per annum, as Congress should find most convenient. The officers in the lines of the respective states were given an option, when acting in each state collectively, as to the acceptance or refusal of the securities offered.

Closely following the passage of the Commutation Act, Congress received on March 24 news of the signing on January 20 of the preliminaries for a general peace. In a letter of March

\footnotetext{
1 Ford, Writings of Washington, $\mathbf{x}, 179-180$. At the same time Washington was writing privately to Joseph Jones: "Nothing is too extravagant to expect from men who conceive that they are ungratefully and unjustly dealt by." Ibid., $\mathrm{x}, 184$.

2 Journals of Congress (1823 edition), iv, 179. Also Hunt, Writings of James Madison, i, 421, 422 .
} 
30, Washington wrote to the President of Congress with "the most lively sensations of gratitude and pleasure," rejoicing principally in the news of the general peace, but also because: "The commutation of the half pay, and the measures adopted for the liquidation of their accounts, will give great satisfaction to the army; and will prove an additional tie to strengthen their confidence in the justice and benevolent intentions of Congress towards them." 1

On April 24, 1783, Congress issued an "Address to the States," dealing with the financial affairs of the nation. Among the obligations to be met was the commutation of half pay, which was estimated at $\$ 5,000,000$, involving an annual interest charge of $\$ 300,000 .^{2}$ The address asked the consent of the states to the laying of an impost duty to provide the general government with an independent revenue.

Though promises made in the dawn of peace seemed good to the Revolutionary officers, they soon found that they were far from enjoying the substantial fruits of fulfilment. In June they were being compelled to leave the army without any settlement or means of paying their debts, and "without an evidence that anything is due to us for our services, and consequently without the least prospect of obtaining credit for even a temporary subsistence." 3 The indefatigable Washington again vigorously championed their cause. On June 8 he addressed from Newburgh a circular letter to the governors of all the states on the occasion of the disbanding of the army. ${ }^{4}$ In advocating public justice and the discharge of public debts, he transmitted a collection of papers relative to the half pay and commutation granted to the officers. With regard to these measures he said: "The resolutions of Congress, now alluded to. are undoubtedly as

1 Ford, Writings of Washington, x, 198-199, footnote.

2 Journals of Congress (1823 edition), 194-197.

3 Major General Heath, acting for the generals and officers of Washington's command, presented an address to Washington, June 5, 1783. This is printed with other papers on the half pay controversy in House Documents, 1st Sess., 19th Cong., 1825-6, vol. viii, No. 135, p. 9. Washington's reply to General Heath may be found in Ford, Writings of Washington, $\mathbf{x}, 251-254$.

4 Ford, Writings of Washington, x, 254-265. 
absolutely binding upon the United States, as the most solemn acts of confederation or legislation." The half pay and commutation ought not to be regarded "in the odious light of a pension." It was a part of the officers' hire. "I may be allowed to say, it was the price of their blood, and of your independency; it is therefore more than a common debt, it is a debt of honor; it can never be considered as a pension or gratuity, nor be cancelled until it is fairly discharged."

Washington defended the distinction that had been made in the matter of half pay and commutation between officers and private soldiers. He thought that all things being duly considered-the large bounties paid the soldiers in some states, the donations of lands, the arrearages of clothing and wages, - the gratuity of one year's full pay was as just as the reward to the officers. However, he would be pleased, if judged equitable, to see some further compensation given the soldiers. $\mathrm{He}$ also urged punctual payment of the pensions to invalids in accordance with the resolutions of April 23, 1782.

Notwithstanding Washington's earnest plea for the keeping of the public faith, opposition in New England to the commutation of the half pay increased rather than otherwise. The Massachusetts legislature changed the representation of the state in Congress as a penalty for concurrence in the Commutation Act, ${ }^{1}$ and also prepared a remonstrance to Congress against the measure. $^{2}$ This document was presented to Congress in July. It asserted that the grant was more than an adequate reward for the services of the officers, "inconsistent with that equality which ought to subsist among citizens of free and republican States," and "calculated to raise and exalt some citizens in wealth and grandeur, to the injury and oppression of others." While horror was expressed at the most distant idea of the dissolution of the union, the resolutions observed "that the extraordinary grants and allowances which Congress have thought proper to make to

1 Madison Papers, i, 557.

2 Journals of Congress (1823 edition), iv, 276. 
their civil and military officers, have produced such effects in this commonwealth, as are of a threatening aspect." For these reasons, the general court refused the consent of the state to the impost duty recommended by Congress in its "Address to the States," but promised to consider the matter again at the next session.

Congress referred the Massachusetts remonstrance to a committee, which reported that the half pay and commutation had been finally adopted, and that it was not now possible to withdraw the promises made to the army officers. What had been done by Congress in the matter of contracting debts before the Confederation was formed was under the Articles a legitimate charge against the United States. To attempt to recall the debt to the officers would sap the foundation of public credit. This committee report was approved by Congress. ${ }^{1}$

In Connecticut hostility to the Commutation Act was widespread and amounted with some people to a frenzy. The files of the Connecticut Courant are filled with letters on the matter. The opponents of commutation asserted that Congress had no right to make the grant and that the officers had obtained the provision by deceit and intimidation. Officers, said the critics, were being rewarded and private soldiers neglected. The soldier would "be obliged to labor the remainder of his life for the support of his officer in ease and affluence."' An impoverished country would have to be taxed to build up and maintain an aristocracy. The defenders of the half pay and commutation replied, recounting the services of the officers and urging that faith should be kept and just debts paid. A large number of the towns of the state took the subject up in town meetings and, in general, passed hostile resolutions. ${ }^{3}$ Some of these resolutions were made the subject of satirical replies.

\footnotetext{
1 For a discussion of the position of Congress in the matter of the commutation of half pay, see J. T. Austin, Life of Elbridge Gerry, i, 395-8.

${ }^{2}$ Connecticut Courant and Weekly Intelligencer, May 13, 1783. Letter signed "Constant Customer."

${ }^{3}$ Ibid., July 29, 1783 . Action of the town of Torrington.
} 
An interesting illustration of the bitterness of the feeling against officers who received the commutation is shown in the meeting of the town of Farmington, August 4, 1783. ${ }^{1}$ This town appointed a committee to consider what was proper to be done relative to Captain William Judd, of said town, who had lately returned from Philadelphia, having, as was reported, obtained securities for the commutation of half pay. There was a unanimous vote of the severest reprehension, and a committee was appointed to serve Captain Judd with a copy of this vote "as a perpetual testimony of our sense in this matter." The captain, who had acted for his brother officers of Connecticut in settling their accounts, defended himself in the next issue of the Courant. ${ }^{2}$ He said that on August 3 he had avoided a mob which had threatened to abuse him and take away the securities, and that on the next day the mob, after annoying his family, had resolved themselves into a town meeting and passed the above mentioned resolutions.

On August 23 a committee for the town of Hartford, associated with committees from other towns, called a general convention of the towns in the state to meet at Middletown on the first Wednesday in September to consider what ought to be done upon the subject of commutation. ${ }^{3}$ Twenty-eight of the towns met at Middletown on the appointed day, and adjourned to meet again September 30, it being represented that many of the distant towns of the state had not received timely notice. ${ }^{4}$ On September 30 forty-eight towns, or over two-thirds of those in the state, were represented at Middletown. ${ }^{5}$ This body gave vent to numerous anti-commutation speeches and resolutions and decided to continue itself in existence. It held several later meetings, issued an address to the people of Connecticut in March, 1784, and came to an end in April. ${ }^{6}$

${ }^{1}$ Connecticut Courant and Weekly Intelligencer, Aug. 12, 1783.

2 Ibid., Aug. 19, 1783.

3 Ibid., Aug. 26, 1783.

${ }^{4}$ Salem Gazette, Sept. 11, 1783; Connecticut Journal, Sept. 10, 1783.

${ }^{5}$ Freeman's Chronicle (Hartford), Oct. 6, 1783.

${ }^{6}$ Stuart, Life of Jonathan Trumbull, 644. Also Hartford Courant, April 20,1784 . 
Noah Webster, then a young man, began his career as a political writer by condemning the action of the Middletown convention and town meetings and upholding the justice of the Commutation Act. He supported the action of Congress in a series of able essays which appeared over the signature "Honorius" in the Connecticut Courant, commencing August 26, 1783. ${ }^{1}$ His active participation in the discussion gives especial value to the account of the anti-commutation movement in a volume of his essays published in $1790 .^{2}$ Webster thought that one of the principal causes of objection to the act was that "while it gave five years' full pay to the officers, (it) allowed but one year's pay (eighty dollars) to the privates; a distinction which had great influence in exciting and continuing the popular ferment, and one that turned a large share of the public rage against the officers themselves."

Webster also pointed out that the opposition to the Commutation Act was largely inflamed by suspicion and fear of the Society of the Cincinnati which had been formed by the disbanded Revolutionary officers. ${ }^{3}$ During the agitation against commutation, a pamphlet against the Cincinnati by Judge Burke of South Carolina appeared in Connecticut and contributed not a little to increase the popular hostility to a settlement of the officers' claims. Judge Burke "attempted to prove that the principles, on which the society was formed, would, in process of time, originate and establish an order of nobility in this country, which would be repugnant to the genius of our republican governments and dangerous to liberty." 4 The alleged attempt to create this order of nobility was denounced, and the commutation was opposed as a tax upon the people to support this aristocracy.

The anti-commutation feeling was so strong in Connecticut that the House of Representatives of that state, in November.

\footnotetext{
${ }^{2}$ Notes on the Life of Noah Webster, i, 65-66. See also the files of the Connecticut Courant.

2 Noah Webster, Essays, 184-187.

${ }^{3}$ For example, see the resolutions of the town of Killingworth in Connecticut Courant, Sept. 2, 1783.

4 Noah Webster, Essays, 186.
} 
1783, protested to Congress that neither the half pay for life, nor the commutation, was warranted by the Articles of Confederation or by any power ever delegated to Congress. But the upper house refused to join in this protest. ${ }^{1}$ Governor Trumbull, too, was a strong supporter of measures to keep the public faith. In his message to the legislature before retiring from office, he did not mention commutation in express terms. But he advised against jealousy of Congress, denial of national obligations, and yielding to popular clamor and tumult. Men of education and weight like Dyer, Wolcott, Oliver Ellsworth, and others were in sympathy with Trumbull's views. ${ }^{2}$ The Connecticut opposition to commutation gradually declined in violence and subsided in the spring of $1784 .^{3}$

Though the disturbance was most violent in Connecticut, it also appeared in Massachusetts and other states.." As already related, the Massachusetts legislature was prompt to protest against the Commutation Act. Governor Hancock, however, urged the assembly to support the credit of Congress and join

1 Journals of Congress (1823 edition), iv, 347. See also Webster, Essays, 185-6, and Boutell, Life of Roger Sherman, 329-332.

2 Stuart, Life of Trumbull, 605-610.

3 George L. Clark, in his History of Connecticut, pages 307-8, says of the anti-commutation agitation in the state: "A sign of the morbid timidity of the time appears in the worry over the Order of Cincinnati, an innocent society of the veterans of the war, organized by General Knox to secure some inextravagant benefits for the old soldiers. The extreme democratic feeling in Connecticut was suspicious of this order, which was about as dangerous as the Grand Army of the Republic. It was imagined by some that the officers of the Revolution were grafters and harpies, who were attempting to obtain riches, which would impoverish their fellow citizens, and Congress was thought to be corrupt for aiding them. These sentiments were expressed in a convention at Middletown (September, 1783), and concurred in by the general assembly at its October session of 1783 . Connecticut did not object to taxation, but she was unwilling to be taxed to advance the Order of Cincinnati. There was danger for a time of sedition among the uninformed, but soon the common sense of the more intelligent minority prevailed to support the measures of Congress, and tranquillity was restored." Compare with the above the views of Alexander Johnston as quoted in the footnote on pages 52 and 53.

4 For example, the Connecticut Courant of August 12, 1783, published resolutions against half pay or commutation by a town meeting held in Amenia Precinct, Dutchess County, New York, on July 4, 1783. 
in giving all reasonable rewards to the army that won independence. $^{1}$

There was some attempt in Massachusetts to follow the example of the Middletown convention. In February, 1784, a plan was made to hold a meeting of all the towns of Suffolk County at Dedham to consider the commutation and also the act of Massachusetts granting an impost. But, on March 15, the Boston town meeting expressed disapprobation of the plan, and it fell through. $^{2}$

Samuel Adams, who, while in Congress, had vigorously opposed the original grant of half pay for life, was among those whose influence served powerfully to quiet the public commotion. He held that Congress had an undoubted right to make the grant, and that, even though the measure should seem to any to have been ill-judged, the states were bound in justice and honor to comply with it.

During the anti-commutation agitation in Connecticut, Noal Webster, hearing that Adams had written a letter deprecating the opposition to commutation, wrote requesting a copy. Adams replied, stating his views at length. He maintained that Congress was the sole judge of the necessary means of supporting the late army, and, if upon their own deliberate counsels and the repeated representations of the commander-in-chief of the army they judged it absolutely necessary to grant the half pay for life, they had an undoubted right to make the provision. He also said that with an annually elected legislature he saw no further use, and probably danger, in the county convention and the like. ${ }^{3}$

How painful an impression the anti-commutation disturbances made upon the mincls of leading statesmen is shown by a letter written by Madison to Randolph while the disorder was at its height. Madison said: "The opposition in the New England States to the grant of half pay, instead of subsiding, has increased to such a degree as to produce almost a general anarchy. In

${ }_{1}$ Salem Gazette, Sept. 11, 1783.

2 Notes on Life of Noah Webster, ii, Appendix vii, 449-453.

3 Wells, Life and Public Services of Samuel Adams, iii, 178, 207-210. 
what shape it will issue is altogether uncertain. Those who are interested in the event look forward with very poignant apprehensions. Nothing but some Continental provision can obtain for them this part of their reward."

However, while the fight against commutation was in progress, the measure was being carried into effect. It was generally acceptable to the army officers, who had feared that they would receive nothing at all. By October 31, 1783, the Secretary of War reported that the commutation had been accepted by the lines of New Hampshire, Massachusetts, Rhode Island, Connecticut, New York, New Jersey, Pennsylvania, Delaware, Maryland, Virginia, and also by numerous separate commands and individuals. ${ }^{2}$ Congress issued a proclamation disbanding the army from and after November $3 .^{3}$

In settling the claims of the officers, the Paymaster General found that the number who were entitled to half pay or commutation was 2,480. Since the Confederation had no available funds to make payment in money, the officers received commutation certificates, payable to them or bearer and drawing interest at six per cent. ${ }^{*}$ A major general's commutation amounted to $\$ 9,960$; a colonel's to $\$ 4,500$; a captain's to $\$ 2,400$; a lieutenant's to $\$ 1,600$; and an ensign's to $\$ 1,200$. There were agents appointed for the several lines of the army who were charged with. the responsibility of delivering the certificates to their owners. The delivery was made early in $1784 .^{5}$

Soon further cause of complaint arose among the officers by reason of the failure of the Confederation to pay the interest on the commutation certificates or provide for their redemption. During the period between 1784 and 1791 many officers were driven by necessity to sell the certificates for what they could obtain, and the cash value of the defaulted securities soon fell

1 Letter of September 8, 1783. Madison Papers, i, 572.

2 Journals of Congress (1823 edition), iv, 311.

3 Ibid., iv, 299.

4 Reports of Committees (H. of R.), 2d Sess., 19th Cong., i, No. 6.

${ }^{5}$ House Doc., 1st Sess., 19th Cong., 1825-6, viii, No. 135, 16-17. 
to twelve and a half cents on the dollar. No effectual provision was made for the redemption of the certificates until August 4, 1790 , when they were embraced in the operation of the act for funding the public debt commencing with January 1, 1791. Those who then owned the certificates received a three per cent stock for the interest in arrears, a six per cent stock for two-thirds of the principal, and a deferred stock, bearing no interest until the expiration of ten years-and then at six per cent-for the other third. ${ }^{1}$ But, when this tardy provision was made, a large share of the certificates was in the hands of speculators, and officers, who had parted with them for a small fraction of their face value, lost all advantage from the settlement. ${ }^{2}$

The officers who had parted with their commutation certificates before the settlement in 1791 complained that through the financial incapacity of the Confederation they had suffered great injustice. Under the newly established federal government, they brought their grievance before Congress and were untiring claimants for relief during nearly forty years. Their claims were pressed especially in $1809,1810,1819$, and 1825-1827. In January, 1826, a House of Representatives committee reported that delegates in behalf of the surviving officers of the Army of the Revolution, from the states of Rhode Island, New York, New Jersey, Pennsylvania, and South Carolina, had recently convened in the city of Philadelphia. They had agreed to present once more to Congress a memorial "in hopes of obtaining from the nation that reward for their services and sacrifices, which, in their opinion, is due, and which has been withheld for a period that is long and unreasonable, and until they have become far advanced in their old age, the youngest among them being within a year or two of seventy."

The efforts of these aged survivors were finally crowned with

1 Act of August 4, 1790, U. S. Statutes at Large, i, 138.

2 For the sake of continuity of treatment, an account of the final settlement of these half pay claims is included in this chapter, although it took place under the federal government in 1828 .

3 House Doc., 2d Sess., 19th Cong., 1826-7, i, Report 6, 1-14. 
success. President John Quincy Adams, in his message of December, 1827, recommended to the consideration of Congress "the debt, rather of justice than gratitude, to the surviving warriors of the Revolutionary War." ${ }^{1}$ Congress responded by the passage of the law of May 15, 1828. ${ }^{2}$

The act of 1828 granted full pay for life, beginning with March 3,1826, to the surviving Revolutionary officers in the continental line, who had been entitled to half pay for life by the resolution of October 21, 1780. Full pay for life was also given to the noncommissioned officers and soldiers, who enlisted for the war and served until its end, and thereby became entitled to receive the reward of eighty dollars promised by the resolution of May 15, 1778. Beneficiaries under this service-pension measure were at first required to give up other pensions which they might be receiving under the laws of the United States, but, under later amendments, they were permitted to retain invalidpensions.

The act of 1828 was not at first regarded as an ordinary pension law, and its execution was entrusted to the Secretary of the Treasury. In 1835 this function was transferred to the Secretary of War. At the end of 1828 , about 850 survivors of the Revolutionary army had been allowed the full pay for life. ${ }^{3}$ Privates who had served to the conclusion of the war were included with the officers, and thus in the end the distinction so obnoxious to New England was removed. After nearly fifty years of intermittent controversy, the half pay claims were finally quieted.

Pension and half pay legislation during the Revolution was intended primarily as an incentive to enlistment and service in the forces of the revolting colonies. Invalid-pension provisions, though poorly carried out, were in entire harmony with long colonial precedent and were generally supported by public opinion. They called for but modest expenditure. On the other hand,

1 House Journal, 1st Sess., 20th Cong., 23.

$2 U$. S. Statutes at Large, iv, 269.

${ }^{3}$ Report of Secretary of Treasury, State Papers, 2d Sess., 20th Cong., ii, No. 68. 
public opinion in several of the states was very hostile to the officers' half pay legislation. Colonial precedent did not warrant such a grant; the idea was undoubtedly drawn from the provision made for retired officers in the British army. The sum involved was, for those days, large, and many felt that the officers had taken unpatriotic advantage of the critical condition of the country to extort the promise of personal reward from a reluctant Congress. The thought of the existence in the country after the war of a privileged class of service-pensioners was very repugnant to advocates of democracy.

As we have seen, Washington was a persistent and steadfast advocate of the claims of the officers. His letters abound with passages describing their privations and the prejudicial effect of their service upon their future prospects. It was in his opinion not enough to appeal to their patriotism. The prospect of personal reward was necessary to retain them in the army. If we are to judge by what he wrote, the commander-in-chief thought a great deal more of what was due the officers than of what was due the soldiers. To be sure, in one of his letters he maintained that, all things considered, the privates had been fairly treated as compared with the officers. But in democratic New England, where the officers and men were of a social position nearer an equal footing than was the case in the Southern regiments, it was felt that there was an obnoxious disparity in the provision made for the two classes. Formation by the Revolutionary officers of the secret and hereditary Order of the Cincinnati served to increase the hostility to a settlement of their claims for fear that support would thereby be given to a privileged aristocracy. ${ }^{1}$

1 Alexander Johnston, in his Conrecticut: A Study of a CommonwealthDemocracy, pages 317-18, takes a just view of the situation in Connecticut and other New England states when he says that the people, "instinctively willing for national taxation, were moved by what may seem an unreasonable jealousy of the Society of the Cincinnati, and were unwilling to see a national taxing power under its control or in its interest. For this, however, there was some excuse. The feeling of the military authorities toward the privates of the Revolutionary armies would seem odd to men of the present day. To Washington, for example, it was always the officers who were the 'gentlemen of the army'; the privates were food for powder, well enough off with rations, clothes and glory. When 'half pay for the army' 
The history of military pensions during the Revolutionary War deals with expenditures that seem almost negligible when compared with the swollen pension disbursements of the present day. But the experience of the founders of our government with pensions is worth knowing, regardless of the amount of money involved. In a country where invalid-pensions have always been willingly granted, there was bitter hostility to the introduction of any sort of service-pensions. Yet they were sought with a persistence and an organized effort that has been repeated more than once in American history. The years from 1776 to 1789 were a time of beginnings, and to understand the importance of the pension question in that critical period will be of much service in unfolding the gradual development of the great national pension system under the federal government.

was proposed by Congress in 1778 , it was only for the commissioned officers; $\$ 80$ apiece in continental money at the end of the war was thought a quite liberal provision for the insignificant privates. It may very easily be seen that such notions as these were not likely to be popular in an ultra-democratic State like Connecticut; and it is probable that her Revolutionary privates were as bitter in their opposition to the Society of the Cincinnati as those who had not entered the army at all. It was not 'the old leaven of Silas Deane,' as Hamilton thought, but the instincts of democracy, that fought against caste distinctions in the army, as elsewhere." 


\section{CHAPTER III}

\section{Revolutionary Pensions, 1789-1878}

Soon after the establishment of the federal government, Congress, in September, 1789, provided for the continuance by the United States of the invalid-pensions which, under Congressional authority, had been granted and paid by the states to soldiers of the Revolution. ${ }^{1}$ This continuance was at first from year to year but was finally extended indefinitely for the life of the pensioners. Through the neglect or failure of states to act, payments to some of the pensioners were much in arrears. The United States undertook to pay these arrears to March 4, 1789. ${ }^{2}$ There was not a complete transfer of all military pensioners from state to national rolls. Some individual states continued to pay regular amounts to persons who had been pensioned for various causes under state laws and without authority of Congress. The administration of the national pension laws was taken over from the states and placed under the supervision of the Secretary of War. However, Congress for a long time reserved to itself direct control over the final allowance of claims.

Under the limitations established by the Congress of the Confederation, December 11, 1788, was the latest date for presenting applications for Revolutionary pensions with supporting certificates and evidence. ${ }^{3}$ Notwithstanding this limitation, the new federal Congress was beset with petitions from soldiers of the Revolution for original pensions or increase. Some petitioners had neglected to apply within the prescribed time limit; others, unsuccessful in the states, came to Congress with their claims. Since the time limit under the general law of the Confederation had expired, relief could be obtained only through the enactment of a new general law or through special legislation for

1 U. S. Statutes at Large, i, 95.

2 Ibid., vi, 4.

${ }^{3}$ Journals of Congress (1823 edition), iv, 821. 
individual cases. Congress frequently referred these pension claims to the Secretary of War, General Knox, for report and opinion. He was in favor of an adherence to the limitation established in 1788. He also maintained that Congress ought to support the decisions already made in the states, saying that applications which had failed under all the circumstances of local information and influence, even though the provision was to be made at the expense of the United States, could not be well founded. However, General Knox recommended that Congress make exceptions in especially meritorious cases. Had his counsels shaped the policy of the government, payments to Revolutionary invalid-pensioners would rapidly have declined in importance. In March, 1792, the number of noncommissioned officers and privates on the general pension list was 1,358 , none of whom received a pension exceeding five dollars per month. The entire number of invalid-pensioners of all descriptions at that time was 1,472 . With no general pension law, and with special acts passed only in exceptional cases, death would have slowly but surely wiped out this small list. ${ }^{1}$

Congress before long yielded to the pressure of applicants, and a new general pension law for Revolutionary soldiers was placed on the statute book March 23, 1792.. ${ }^{2}$ This measure was not long in force, but it is important as the first of a long series of Revolutionary pension laws passed under our present federal government and also as the occasion of an interesting controversy regarding the constitutional functions of the federal judiciary.

In one of his reports to Congress, Secretary Knox had pointed out the inadequacy of ex parte certificates as evidence on which to base the granting of pensions. If Congress wished to pass a law on the subject, he had suggested a method of administration under which district judges, or other designated officers of the United States, should in person receive the petitions and evidence from the applicants, and should transmit the same to Con-

1 Reports of Secretary Knox, American State Papers, Claims, 1790-1823, $5,8,18,28,57$.

${ }^{2} U$. S. Statutes at Large, i, 243. 
gress for final decision. ${ }^{1}$ By the act of 1792 Congress attempted to put into operation a plan of this sort. The law imposed upon the circuit courts of the United States the duty of examining, in person, applicants for pensions, receiving prescribed proofs of disability and service, and determining the nature and degree of the disability. Whenever an applicant was found to be entitled to be placed on the pension list, the court was required to transmit a written report to that effect to the Secretary of War with an opinion as to the part of the monthly pay of the applicant which would be proportionate to the degree of disability ascertained. The Secretary of War was then to place the name of the applicant upon the pension list of the United States in conformity to the opinion of the court and accompanying certificates. But when the Secretary suspected imposition or mistake. he was empowered to withhold the name from the pension list and make report of the matter to Congress for consideration at the next session. Thus each circuit court was virtually constituted a bureau for the examination and allowance of pension claims, with its decisions subject to revision by the Secretary of War and Congress.

The power of Congress to impose upon them such duties as those above described was promptly denied by the federal judges. Chief Justice John Jay and Associate Justice William Cushing of the Supreme Court, sitting with James Duane, district judge, as a circuit court for the district of New York, sent in April, 1792, a letter of protest to President Washington which they desired him to communicate to Congress. ${ }^{2}$ They asserted that the judiciary was a distinct and coordinate branch of the government and that neither the legislative nor the executive branch could constitutionally assign to the judicial any duties but such as were properly judicial and to be performed in $a^{\prime}$ judicial manner. They thought that the duties prescribed by the act in question were not of that description, since the decisions of the court were made

1 American State Papers, Claims, 1790-1823, 29.

2 Ibid., Miscellaneous, i, 49-53. See also Carson, Supreme Court of United States, 162-3. 
subject to suspension by the Secretary of $\bar{W}$ ar and to revision by the legislature. Under the Constitution neither an executive officer nor even the legislature was authorized to sit as a court of errors on the judicial acts or opinions of the circuit courts. The judges of the New York circuit were, however, willing to regard themselves as commissioners, designated by official instead of personal descriptions, and therefore at liberty either to accept or decline the office. As the objects of the law were benevolent, they agreed to pass upon claims as commissioners in the same room in which the court was held, adjourning court for that purpose for short periods during the session.

In June the judges of the North Carolina circuit also expressed the opinion that the court could not execute the recent pension act. They were inclined to consent to act as commissioners, although they expressed doubt whether they were warranted in doing so. ${ }^{1}$ Associate Justice Iredell, who was one of the judges on the North Carolina circuit, had, by the fall of 1792, become reconciled to the propriety of transacting invalid-pension business out of court. ${ }^{2}$

The Pennsylvania circuit court, consisting of Associate Justices Wilson and Blair and District Judge Peters, took an uncompromising position regarding the pension act. Their objections to the measure were similar to those made by the judges of the New York circuit; but they did not offer or consent to serve as commissioners. In fact, on April 11, 1792, they refused to proceed upon the petition of William Hayburn, an applicant for a pension under the act of 1792. The reasons for their refusal were explained in a letter to the President under date of April 18, in which they said that the assignment by Congress of duties to the judges as provided by the pension act was contrary to the Constitution. ${ }^{3}$ Thus it is reasonable to assert that the Pennsylvania circuit court in this case declared the invalid-

1 American State Papcrs, Miscellaneous, i, 52.

$2 \mathrm{McRee}$, Life and Correspondence of James Iredell, ii, 361.

3 American State Papers, Miscellaneous, i, 51. 
pension act of 1792 unconstitutional, affording the first instance of the nullifying of an act of Congress by a federal court. ${ }^{1}$

Because of the refusal of the Pennsylvania circuit court to proceed under the act of 1792, Attorney General Randolph, at the August term of the Supreme Court in that year, made application for a writ of mandamus directing the Pennsylvania court to pass upon the case of William Hayburn. ${ }^{2}$ The Attorney General at first made his motion $e x$ officio, with a view to procuring the execution of an act of Congress particularly interesting to a meritorious and unfortunate class of citizens. A divided court held against his right to proceed ex officio. He then changed the ground of his interposition, declaring it to be at the instance of Hayburn, a party interested. After he had presented his argument, the court announced that it would hold his motion for a writ of mandamus under advisement until the next term; but no decision was ever pronounced, as Congress, before the next term of court, provided in another way for the relief of pensioners. Chief Justice Taney referred to this case in his opinion in $U$. S. $v$. Ferreira, decided at the December term, 1851. He considered that the question before the court in the mandamus proceedings was whether the pension act might not be construed as conferring power on the judges personally as commissioners. All the judges of the Supreme Court, except one, had already expressed opinions in writing that the pension act prescribed duties for the judges. which could not be carried out as a judicial power. ${ }^{3}$ However,

1 Professor Max Farrand calls the refusal of the Pennsylvania circuit court to proceed upon the petition of William Hayburn "The First Hayburn Case" as distinguished from the later application for a mandamus writ on behalf of Hayburn before the Supreme Court. In an article in the American Historical Review, xiii, 281, Professor Farrand presents the historical evidence in favor of the assertion that this was the first case in which a federal court declared an act of Congress unconstitutional.

2 Hayburn's Case, 2 Dallas, 409 . In Curtis, Reports of Decisions in the Supreme Court of the United States, i, 8.

${ }^{3}$ Chief Justice Taney said (U.S. v. Ferreira, 13 Howard, 50): "These opinions [of the various circuit courts], it appears by the report in 2 Dall., were all communicated to the President, and the motion for a mandamus in Hayburn's case, at the next term of the supreme court, would seem to have been made merely for the purpose of having it judicially determined in this court, whether the judges, under that law, were authorized to act in the 
the Supreme Court does not appear to have declared formally that the act of 1792 was unconstitutional.

Claims under the act of 1792 were passed upon by some of the judges, styling themselves commissioners. When Congress passed a new pension law in February, 1793, it directed the Secretary of War, in conjunction with the Attorney General, to take such measures as might be necessary to secure from the Supreme Court an adjudication of rights to pensions claimed under the determination of the so-called commissioners. ${ }^{1}$ To test the question Attorney General Randolph applied to the Supreme Court at the August term, 1793, for a writ of mandamus directing the Secretary of War to place upon the pension list one of those who had been approved by judges acting in the character of commissioners. A decision in this case would have involved all the others. Two of the judges of the court expressed a disinclination to hear Randolph's motion on behalf of a man who had not employed him for that purpose. Thereupon Randolph thought it best to waive the motion until some of the invalids themselves should speak to counsel. ${ }^{2}$

At the term of the Supreme Court in February, 1794, William Bradford, who had become Attorney General, arranged to have a case brought before the court to test the validity of the adjudications of the so-called commissioners. On May 23, 1792, Yale Todd, a Connecticut claimant, had appeared before the judges acting as commissioners at New Haven. They transmitted a report to the Secretary of War that he ought to be placed on the pension list. He was placed on the list and received $\$ 172.91$ pension and arrears. The Attorney General arranged to have

character of commissioners. For every judge of the court, except Thomas Johnson, whose opinion is not given, had formally expressed his opinion in writing, that the duty imposed, when the decision was subject to the revision of a secretary and of congress, could not be executed by the court as a judicial power; and the only question upon which there appears to have been any difference of opinion, was whether it might not be construed as conferring the power on the judges personally as commissioners."

1 U. S. Statutes at Large, i, 324.

2 American State Papers, Miscellaneous, i, 78. Letter of Edmund Randolph, Attorney General, to H. Knox, Secretary of War. 
suit brought against Todd for the amount. It was agreed that if the judges had power to act as commissioners, the verdict should be for Todd. If they had no such power, the verdict should be for the United States. The case was decided against Todd, thus determining that the judges could not act as commissioners under the pension law of 1792. ${ }^{1}$ But this decision did not deal with the more important question of the constitutionality of the law. The only decision based upon the unconstitutional character of the act was that of the Pennsylvania circuit court upon the original application of William Hayburn. The opposition of the federal judiciary to the provisions of the pension law of 1792 was an important and early step in the assertion of the exalted position of what has grown to be the most independent judicial body in the world.

Congress yielded to the objections of the judiciary in the act of February 8, 1793, which repealed the objectionable sections of the act of 1792 and established new regulations. ${ }^{2}$ Federal judges, however, still played a part in the pension administration. All evidence relative to applications for invalid-pensions was to be taken upon oath before the judge of the district in which the applicant resided, or before any three persons commissioned by the judge. Claimants were required to prove decisive disability resulting from known wounds received while in actual line of duty in the service of the United States during the Revolutionary War. Each district judge was directed to transmit a list of claims, accompanied by all required evidence, to the Secretary of War for comparison with the muster rolls and other documents in his office. The Secretary was then to make a statement of the cases to Congress, which reserved to itself the final action in the allowance of claims. It will be noticed that the act of $1793 \mathrm{im}-$ posed no duty of making a decision upon the judges. The district

1 American State Papers, Miscellaneous, i, 78. Report of Attorney General William Bradford to the Secretary of War. Also see United States v. Yale Todd, 13 Howard, 52-54. This case was not printed when originally decided, February 17, 1794, but is set forth in a note by the Chief Justice appended to United States v. Ferreira, 13 Howard, 50.

$2 U$. S. Statutes at Large, i, 324. 
judges, or persons commissioned by them, merely took the evidence upon oath and transmitted it to the Secretary of War for further action. ${ }^{1}$ No claim under the act of 1793 was to be allowed unless presented within two years from its passage.

The evidence in support of many of the applications under this act was very defective. Muster rolls were lost, and the proof, in most cases, depended solely upon the affidavits produced by the claimants. As provided by the law, the Secretary of War transmitted to Congress lists of the claimants. In one instance, Congress granted pensions to all persons included in the Secretary's report whom he should find to have clearly established their claims. $^{2}$ In acting upon later lists, Congress specifically named each individual to whom a pension was granted, together with the rate at which he was to be paid. ${ }^{3}$ A full pension for a noncommissioned officer or private soldier was fixed at five dollars per month, and for a commissioned officer at one-half of his monthly pay.

In view of the later history of the pension system, it is worthy of note that there were claims made under the act of 1793 for arrears of pensions, but a congressional committee investigated the matter and reported unfavorably in 1795 . It recommended that pensions commence at the completion of testimony and continue during disability. ${ }^{4}$ After being admitted to the pension roll, invalids received their allowances through agents for paying pensions located in the various states. Prior to 1800 the average annual expenditure for Revolutionary invalid-pensions was considerably less than one hundred thousand dollars. ${ }^{5}$

No important alterations in the existing pension laws were made until 1803. There seems to have prevailed a laudable disposition to guard the interests of the government against claims

${ }^{1}$ For examples of such lists, see American State Papers, Claims, 85-128.

2 U. S. Statutes at Large, i, 392.

3 For example, see act of April 20, 1796, ibid., i, 454.

- American State Papers, Claims, 146.

5 Ibid., Finance, i, 662. Also see Ibid., Miscellaneous, i, 305. 
of an unreasonable or fraudulent character. On a proposition in 1798 to amend the laws respecting invalid-pensioners, the Committee on Claims of the House of Representatives, after reviewing the course of pension legislation to that date, reported that "the provisions heretofore made for admission of claims of this nature have been as extensive as the principles of justice, equity or good policy required; and that it would not be expedient to make any alteration in the existing laws." 1 Such views, however, did not long prevail. In 1795 the act of 1793 expired and left the statute books for some time without any general provision for the further admission of Revolutionary pension claims. The solicitations of claimants continued, and, in 1803, Congress was prevailed upon to enact a new invalid-pension law. ${ }^{2}$ Rates remained as under the act of 1793 , and the method of administration was much the same. The most important change in procedure was the endowing of the Secretary of War with the power of final decision in the allowance of claims.

The law of 1803 was followed by a supplementary act of 1805 extending the benefits of the pension law to those who, in consequence of known wounds received in the military service during the Revolution, had at any period since the war become and continued disabled so as to render them unable to procure a subsistence by manual labor. ${ }^{3}$ This opened the way for the tracing of the ills and disabilities of later life to wounds from which the claimants had apparently recovered. Such legislation is interesting as the forerunner of similar provisions which, when later applied to service in the Civil War, were both open to great abuse and exceedingly costly.

Invalid-pension legislation on behalf of soldiers of the Revolution reached its most comprehensive form in the act of April $10,1806,{ }^{4}$ and supplementary provisions. This measure repealed all former enactments for the relief of Revolutionary invalids

\footnotetext{
1 American State Papers, Claims, 216-8.

2 U. S. Statutcs at Large, ii, 242.

${ }^{3}$ Ibid., ii, 345.

4 Ibid., ii, 376.
} 
and became the fundamental provision upon which the pension claims of such invalids were thereafter based. It did not, of course, affect pensions already granted. Within its scope were included all the classes of claimants previously provided for, and, in addition, all volunteers, militia and state troops, who had served against the common enemy during the war. Disability must have been the result of known wounds received in the line of duty, and must have been such as to render the applicant wholly or partially unable to procure a subsistence by manual labor. Desertion was a bar to a claim. The method of taking evidence and examining claims was similar to that under the laws of 1793 and 1803. Congress, however, once more reserved to itself that power of final action in placing names on the pension list which had been delegated to the Secretary of War under the act of 1803. Rates were the same as under previous laws, and each pension commenced from the date of the completion of the testimony. For the first time regulations were established in accordance with which an increase of pension might be granted by Congress in cases where justice required, but, with the increase added, no more than a total disability rate might be paid. The operation of this law was limited to six years from the date of its passage.

In carrying out the act of 1806 , Congress passed a series of laws, pensioning long lists of claimants at varying rates per month. On April 25, 1808, a measure of this character was passed, containing a section which completed the assumption by the United States of the payments to all the Revolutionary invalid-pensioners remaining on the rolls of the states. ${ }^{1}$ This included all such persons whether their disability was incurred on land or sea, in the service of the United States or of any particular state, in the regular army, militia or volunteers. When the act of 1806 expired by limitation in 1812, it was renewed and continued in force for six years by the act of April 25, 1812. It was afterwards revived for one year by the act of May 15,

${ }^{1}$ U. S. Statutes at Large, ii, 491. 


\section{FEDERAL MILITARY PENSIONS IN THE UNITED STATES}

1820 , and for periods of six years each by the acts of February 4, 1822, and May 24, 1828. ${ }^{1}$ The later renewals were subject to amendments which had been made, and which will be mentioned in due time.

Beginning with 1816 the condition of the federal Treasury was unusually favorable to the expansion of public expenditures. During the War of 1812 the United States had borrowed more money than was really needed. New internal revenue taxes had been levied in 1814, and the beginning of 1816 found the Treasury with the largest credit balance since the organization of the government. ${ }^{2}$ A proposition was soon put forward to use some of the surplus funds to increase the rates paid to invalidpensioners. In support of the measure, it was said that the cost of living had increased and that invalids should have enough to support themselves "plentifully and comfortably." 3 An increase law was speedily passed on April 24, 1816, raising the rate of full pension for a private from five dollars to eight dollars per month. ${ }^{4}$ Pensions of first lieutenants and commissioned officers below that grade were also increased to the extent of two or three dollars a month. The act applied both to those already on the rolls and to persons who should thereafter be granted pensions. About the time of the passage of this law, the United States was expending annually $\$ 120,000$ for pensions. There were 185 officers and 1,572 noncommissioned officers and soldiers of the Revolutionary army on the roll of invalids, and 52 officers and 391 soldiers who had become disabled since the Revolution, making an aggregate of 2,200 pensioners. ${ }^{5}$ It was estimated that the act of 1816 would increase the annual expenditure for pensions to about two hundred thousand dollars, including the claims allowed on account of the War of 1812 .

1 U. S. Statutes at Large, ii, 718 ; iii, 596, 650; iv, 307.

2 Dewey, Financial History of the United States (1903), 142 and following.

${ }^{3}$ Report of House of Representatives Committee on Pensions and Revolutionary Claims, American State Papers, Claims, 473-474.

$4 U$. S. Statutes at Large, iii, 296.

- American State Papers, Claims, 473-474. 
The increase granted by the act of 1816 proved but a light burden upon the swelling revenues. The flood of imports from England following the War of 1812 enormously increased the customs revenue in 1816 , during which year a distinctively protective tariff was enacted. Estimates had been made that the customs revenue for the year would be thirteen million dollars, but the actual returns from this source amounted to thirty-six million dollars. ${ }^{1}$ Though the revenues were somewhat less swollen in 1817 , that year was also unusual in its yield. Such conditions of Treasury surplus paved the way for the introducton in our federal pension system of service-pensions.

In his message of December, 1817, President Monroe "in contemplating the happy situation of the United States" drew the attention of Congress to the services of the Revolutionary soldiers, of whom he thought the survivors were few. Some were reduced to indigence and real distress, and he asked that provision be made for them. ${ }^{2}$ General Bloomfield of New Jersey promptly reported to the House of Representatives a bill designed to comply with the President's recommendation. In the extender debates on this measure, there was shown to be a wide diversity of opinion in Congress regarding the proper nature and scope of pension legislation. The law as finally enacted was quite different from the original bill. In both houses there were decided majorities in favor of the passage of a service-pension law, but, as to detailed provisions, there was lack of agreement. Some wished a measure based solely on a service requirement; others advocated a provision based upon "service and poverty." There was no definite knowledge as to the probable number of applications which would follow the passage of the proposed law, nor had its advocates any conception of its probable cost. Such estimates as they attempted proved ridiculously small in the light of later experience. ${ }^{3}$ The supporters of the measure

1 Dewey, Financial History of the United States, 161.

2 Annals of Congress, 1st Sess., 15th Cong., 1817-1818, i, 19.

3 In the Senate, Goldsborough of Maryland estimated the number of applicants under the law as, at the largest, less than 1900. 
pointed complacently to the surplus in the Treasury. The burden of their argument was eulogy of the Revolutionary soldiers, praise of their services, descriptions of the privations they had undergone, and an appeal to the gratitude of the country. "Let us show the world that Republics are not ungrateful," said one of the speakers. Another appealed to Congress thus: "Permit not him, who, in the pride of vigor and youth, wasted his health and shed his blood in freedom's cause, with desponding heart and palsied limbs to totter from door to door, bowing his yet untamed soul to meet the frozen bosom of reluctant charity."

In the Senate the proposed service-pension act met with strong opposition on the part of the minority. Senator William Smith of South Carolina asserted that the bill was a way to get rid of a little money in the Treasury not immediately wanted. He opposed a service-pension provision on principle and questioned its constitutionality. To those who supported the measure from sentiment, he said that good feelings were a miserable guide to a legislator. The following extract from his speech is prophetic in the light of later experience:

As an argument, it would appear, to avoid an inquiry into the propriety of this measure, we are told such a case can never happen again-that you can never have another Revolutionary War. Will not those brave men who fought your battles and triumphed so gallantly over the enemy at Chippewa, Plattsburg, Erie, Champlain, Orleans and on the seas, have the same claims upon their country some thirtyfive years hence, when time shall have thrown a veil over all the minute circumstances, and it shall be forgotten that they retired from the army with reluctance, after being abundantly paid and abundantly honored?

Their claim will be as great, and the precedent you are about to make will be followed. One army you say gained your independence, and the other has given it a new character, and made it worth maintaining. They have released your country from its degraded state of impressments, paper blockades, royal orders in council, and imperial decrees, and given it as high a grade in the scale of nations 
as your independence. This will be the beginning of a military pension system which posterity may regret. ${ }^{1}$

The force of Senator Smith's words is felt when we remember that service-pension laws, more or less limited, have been passed on account of the War of 1812, the Mexican War, the Indian Wars, and the Civil War. During the Confederation the granting of service-pensions to Revolutionary officers for life had been so bitterly opposed that the payment of a lump sum as commutation was agreed upon in compromise. But the precedent for service-pensions was finally established in the case of the Revolutionary soldiers in 1818 and has cost the national Treasury many hundreds of millions of dollars in its application to our other wars.

While the law of 1818 passed the House of Representatives without division, its scope was considerably linited by amendments in the Senate. It provided that every person who had served in the Revolutionary War until its close, or for the term of nine months or longer at any period of the war, on the Continental establishment or in the navy, and who was a resident citizen of the United States, and was by reason of his reduced circumstances in life "in need of assistance from his country for support," should receive a pension. ${ }^{2}$ The rate for officers was $\$ 20$ per month, and for noncommissioned officers or privates $\$ 8$ per month, during life. No person was entitled to receive the benefits of the act until he should have relinquished his claim to every pension heretofore allowed him by the laws of the United States. In administering the law the evidence in support of claims was taken before the district judges of the United States, or before any court of record of the state or county in which the applicant resided. If satisfied of the claimant's service, the judge transmitted the testimony and the proceedings in the case to the Secretary of War, whose duty it was, if he considered the

1 For Senator Smith's speech, see Annals of Congress, 1st Sess., 15th Cong., i, $140-150$.

$2 U$. S. Statutes at Large, iii, 410. 
claim a legal one, to place the applicant on the pension list of the United States. The statute prescribed no method of proof of the claimant's need of assistance, but the regulations of the War Department required his oath and the certificate of the judge to establish that fact. ${ }^{1}$ Pensions, if allowed, commenced from the date of the applicant's declaration. The law gave the Secretary of War final power in the allowance of claims.

President Monroe and the members of Congress, who had expressed the opinion that there were but few survivors of the Revolutionary army, must have been surprised at the eager rush for pensions under the new law. By the middle of September, the number of applications was so great that it was not possible for the War Department with every exertion to act upon them as fast as they came in. ${ }^{2}$ As flagrant abuses of the act came to light, they were made the subject of severe comment in the newspapers of the time. ${ }^{3}$ Men of means were charged with having made themselves out to be paupers in order to receive the benefits of the law, and others were said to have deposited the whole amount of their pensions in savings banks. The country at large was indignant at the frauds and surprised that a measure proposed for the benefit of a few Revolutionary survivors was likely to increase the annual pension expenditure from two or three hundred thousand dollars to two or three millions. In fact, the prospective cost of the new service-pension law during the year 1820 was more than that of the entire pension system from the organization of the government down to $1818 .{ }^{4}$

Connecticut, which had fought the officers' half pay and commutation during and after the Revolution, was a center of opposition to the act of 1818 . Very fittingly, it was at Middletown,

1 American State Papers, Claims, 682-684.

2 Niles' Register, xv, 63.

3 Ibid., xvii, 99. Contains excerpts from various newspapers.

4 The appropriation for pensions under the act of 1818 for the year 1820 was $\$ 2,766,440$. (House Doc., 21st Cong., 1st Sess., iv, No. 90, 6-7.) Entire amount expended on pensions from beginning of federal government through the year 1817, $\$ 2,662,525$. (House Doc., 16th Cong., 1st Sess., 1819-1820, v, No. 75.) 
the seat of the anti-commutation convention, that popular indignation received a most striking manifestation. The inhabitants held a town meeting on December 6,1819 , at which a preamble and resolutions were adopted. ${ }^{1}$ Complaint was made that great impositions had been practised by sundry persons in obtaining pensions and that individuals in affluent circumstances had obtained the reward due only to the needy and destitute. "Consequently," the resolution said, "many in the community less able to bear the burthens of government are compelled to pay heavy taxes to support their more opulent neighbors." The meeting resolved to ascertain the number of those improperly placed on the pension lists in Connecticut and to cause their names to be erased. The selectmen of the town were constituted a committee to report the names of persons improperly pensioned to some one of the Connecticut delegation in Congress. It was also recommended to the other towns of the state to adopt similar measures.

Elsewhere the pension law found defenders. The New York Evening Post of December 15, 1819, commenting editorially upon the opposition to the act, said: "The fact is, the complaints which some of our newspapers have made, were engendered by a few disorganizers in Connecticut, from the worst of motives; and we fondly trust, that Congress in its wisdom and philanthropy, will let the subject pass undisturbed."

A change in the financial condition of the country gave added force to the discontent caused by the abuse of the pension law. Whereas 1816 and 1817 had been years of unusual revenues and an overflowing Treasury, the period from 1818 to 1821 was one of financial perplexity. ${ }^{2}$ About the same time that Congress undertook the burden of large new expenditures for pensions in the spring of 1818, it provided, on President Monroe's recommendation, for the reduction of the income of the government by the repeal of the internal revenue taxes. By the fall of 1818

${ }^{1}$ Daily National Intelligencer (Washington), January 7, 1820.

2 Dewey, Financial History of the United States, 165-167. 
more stringent financial conditions were felt, and in 1819 the country experienced a severe business crisis followed by a period of industrial and commercial depression. ${ }^{1} \quad$ In 1820 and 1821 the federal government had to resort to loans to meet its obligations. ${ }^{2}$ Under such circumstances it was natural that the unexpectedly large burden for pensions should cause irritation and demands for the repeal or revision of the act of 1818 .

When the sixteenth Congress met in December, 1819, the abuses of the service-pension law were promptly brought to its attention. Secretary of War Calhoun admitted that, in spite of every precaution, his department had probably been imposed upon to a considerable extent as to the circumstances of claimants. His report also showed that, in numbers of pensioners under the law, the leading states were as follows: New York, Massachusetts, District of Maine, Connecticut, Vermont, New Hampshire and Pennsylvania. The entire absence of Southern states from this list is noticeable. ${ }^{3}$

One of the first steps taken by Congress in dealing with the situation was to order the publication of a roll of all pensioners under the act of 1818 , arranged by states. ${ }^{4}$ A congressional committee was also engaged during the spring of 1820 in investigating the pension problem. In the meantime, the discussion of the whole matter continued in the public press. A writer in the Hartford Times attributed the Treasury deficit to the increase in pensions. He informed the public that the abuses in Connecticut started with certain notables, who drew pensions although very affluent men, and suggested the propriety of taking measures similar to the action at Middletown. This writer also pointed out that the pension money was raised by indirect taxation on such articles as sugar, tea, rum and cloth, thus being a

${ }^{1}$ Burton, Crises and Depressions (1902), 275-276. Also Taussig, Tariff History of the United States (6th edition), 73-74.

2 Report of Secretary of Treasury Crawford, House Doc., 16th Cong., 2d Sess., 1820-1821, i, No. 9, 17-18.

3 American State Papers, Claims, 682-684, 703-704.

4 Ex. Papers, 16th Cong., 1st Sess., iv, No. 55. 
relatively heavy burden upon the laborer with a large family. ${ }^{1}$ The National Intelligencer, in an editorial in defense of the federal administration, explained the necessity for a public loan. It attributed the Treasury deficit to the past and present expenditures under the pension law which, it said, would not have been passed "could the extent and inequality of its operation have been foreseen." However, the law would not now be revoked. ${ }^{2}$

The Congressional investigation of pension abuses led to remedial legislation in the act of May 1, $1820 .^{3}$ Those who had been granted pensions under the act of 1818 , and also all who should thereafter apply for pensions under that law, were required to submit sworn schedules of their whole estate and income, exclusive of necessary clothing and bedding. They were also required to take oath that they had not disposed of any part of their property with the intention of bringing themselves within the provisions of the law, and that they had not in person or trust property or income of any kind other than that shown in the schedules subscribed by them. The Secretary of, War was authorized to strike from the list of pensioners those persons, who, in his opinion, were not in such indigent circumstances as to be unable to support themselves without the assistance of their country. Revolutionary invalid-pensioners, who had relinquished their pensions in order to avail themselves of the act of 1818, and who by virtue of the above provisions might be stricken from the pension list, were to receive their former invalid-pensions.

Thousands of pensioners were stricken from the rolls under the provisions of the law of 1820 . Of those who applied for continuance, many suffered a rejection of their claims; others, without hope of favorable action, failed to exhibit the required schedules and were consequently dropped. The fact that there had been much fraud and imposition at the expense of the gov-

1 Quoted in National Intelligencer, March 3, 1820.

2 National Intelligencer, April 25, 27, 1820.

3 U. S. Statutes at Large, iii, 569. 
ernment was clearly established. ${ }^{1}$ Naturally there was much complaint among those who suffered the loss of their pensions. A correspondent of the National Intelligencer wrote:

It was not the number or magnitude of frauds practised under the first law, that gave birth to the second; but the number of applicants, and the accumulation of expense, and hence the inference of fraud was made a pretext for imposing conditions which the most meritorious class of applicants could not submit to; and in this pitiful manner is money to be saved, at the expense of justice and national honor! There can not be better evidence of the ardor with which the youth of that eventful period flocked to the standard of liberty than that so many thousand actors in the army of the Revolution still survive. ${ }^{2}$

The government was in serious financial difficulty throughout the year 1820 , and a loan of $\$ 3,000,000$ was secured under the act of May 15 of that year. Industrial and financial depression continued, and at the close of the year conditions, as indicated by the public revenues, were worse rather than better. On December 21, Crawford, the Secretary of the Treasury, reported a probable Treasury deficit on January 1, 1821, of over $\$ 4,200,000$. To provide for the expected deficiency of the revenues in 1821 , he recommended not additional taxes but another loan. A new loan of $\$ 5,000,000$ was authorized on March 3, $1821 .^{3}$

The second session of the sixteenth Congress was held under these unpropitious circumstances and was occupied with finding means of retrenchment. In the House of Representatives Mr. Cobb of Georgia, observing that he felt that he was "walking upon ticklish ground," proposed to make a considerable saving by reducing pensions. However, his resolution to instruct the Committee on Revolutionary Pensions to inquire into the expe-

1 Regarding the execution of the act of 1820, see Niles' Register, xix, 243.

2 National Intelligencer, Sept. 22, 1820.

3 Reports of Secretary Crawford, House Doc., 16th Cong., 2d Sess., 18201821 , i, No. 9, especially pages 17 and 18. Also ibid., No. 32, page 4. For a discussion of the financial embarrassments of the country, see Dewey, Financial History of the United States, 167. 
diency of making such a reduction was defeated by 59 to $53 .{ }^{1}$ Though openly attacking the pension expenditures was for politicians walking on ticklish ground, there is evidence that the leaders felt that the pension law of 1818 was a principal cause of the financial embarrassments of the administration. An interesting light is thrown upon the matter by a passage in the memoirs of John Quincy Adams. After authorizing the new loan of $\$ 5,000,000$, the sixteenth Congress had adjourned on March 3, 1821. "Near one in the morning" Adams "walked home in company, as far as his house, with Mr. Calhoun." As they conversed intimately on the events of the session just closed, the New Englander found the South Carolinian dispirited by the "results of the attacks systematically carried on through the whole Congress, but especially through the session just expired, against his management of the War Department." And he records Calhoun's conviction that "the present embarrassments in the Administration all originated in two measures of the first session of Congress under it - the repeal of the internal taxes, and the profuse Pension Act." ${ }^{2}$ The Secretary of War, who was charged with the administration of the pension act, had been required to wield "a scythe of retrenchment," and doubtless an element in the unpopularity of his department was the resentment of the large numbers of pensioners who had been cut off from the rolls under the operation of the remedial law of $18200^{3}$

In a report made to the Senate in February, 1823, on the operation of the acts of 1818 and 1820, Secretary Calhoun showed that the total number of persons whose claims to Revolutionary service-pensions had been admitted was 18,880. On September 4, 1822, there were 12,331 of these on the rolls; the

1 Annals of Congress, 16th Cong., 2d Sess., pages 449, 715, 721, 730, 822.

2 Memoirs of John Quincy Adams, v, 314-315.

${ }^{3}$ Calhoun had little reason to fear unpopularity in his own state by reason of his strict construction of the pension laws. Even at this early date, by far the larger part of the pension expenditures went to the North. Senator Smith of South Carolina and other Southerners were the strongest opponents of the act of 1818. In the House of Representatives, Mr. Cobb of Georgia had sought to reduce pensions in 1820 and 1821 . 
remainder had for the most part been removed by the operation of the act of 1820 . The sum paid to pensioners in 1818 under the act of that year was $\$ 105,000$; in $1819, \$ 1,811,000$. In 1820 , $\$ 2,766,000$ was appropriated for the service-pensions, but the actual expenditure was only $\$ 1,374,000$, the list of pensioners having been much reduced by the operation of the act of May 1, 1820. No new appropriation under the act of 1818 was made in 1821 , but $\$ 1,200,000$ was paid from the unexpended balance of the year 1820. In 1822 the sum paid for the service-pensions was $\$ 1,834,000$, including $\$ 452,000$ that should have been paid in the previous year. ${ }^{1}$ Invalid-pension expenditures had also largely increased as a result of the War of 1812. While in 1812 the national pension appropriations amounted to less than one hundred thousand dollars, the combined appropriations for invalid- and service-pensions in 1822 were nearly two million dollars. $^{2}$

It was not long before persons who had been pensioned under the act of 1818, and later dropped from the roll because of their property, began to apply to the Secretary of War to be restored. Calhoun held that, when it was evident that a mistake had been made, the former pensioner might be restored; but in no other case. Many claimants alleged that they had since become so reduced in means as to need the pension. But, on the advice of the Attorney General, the Secretary held that under the law there was no power vested in his department to replace the names of such persons on the rolls. ${ }^{3}$ However, in 1822 the Treasury entered upon another period of prosperity, and applicants for restoration to the pension list found Congress favorably disposed. The act of March 1,1823 , restored pensions to many of those who had been dropped under the law of 1820 on the ground that they had since become so impoverished as to

1 American State Papers, Claims, 885.

2 The total expenditures by the federal government for pensions from its organization to 1818 were less than $\$ 2,700,000$ in all. House Doc., 16th Cong., 1st Sess., 1819-1820, v, No. 75. For the appropriations for 1822, see House Doc., 21 st Cong., 1st Sess., iv, No. 90, 6 and 7.

${ }^{3}$ House Doc., 17th Cong., 1st Sess., vii, No. 72. 
need assistance for their support. ${ }^{1}$ In November, 1823, the pension list, including both service- and invalid-pensioners, contained 17,439 names, and the annual cost of pensions was about $\$ 1,650,000 .^{2}$

The volume of pension business had now become so large that Congress finally abandoned the attempt to participate in the detailed administration of the general laws. The fourth section of an act of March 3,1819, gave the Secretary of War power to place persons entitled to invalid-pensions under the act of April 10,1806, and under the fourth section of the act of April 25,1808 , upon the pension list without reporting to Congress for final action. ${ }^{3} \quad$ As to service-pensions, this power had already been conferred upon the Secretary by the original terms of the act of 1818. However, Congress had usually been guided by the recommendations of the Department during the period in which it reserved to itself the power of final action.

At the same time another change in the method of administering the pension laws was a provision for the biennial examination of invalid-pensioners by two surgeons or physicians. This examination had in view the removal from the roll of those invalids who had recovered from their disabilities. In cases where the pensions were originally granted for total disability in consequence of causes which could not in whole or in part be removed, the examination was not required. An exception was also made in favor of invalid-pensioners of the Revolution who had availed themselves of the act of March 18, 1818. ${ }^{4}$

Several years elapsed before there was any further Revolutionary pension legislation of importance. As related in an earlier chapter, the old question of the settlement of the half pay claims of the Revolutionary officers again came to the front

${ }^{1} U$. S. Statutes at Large, iii, 782. Found in statutes among acts of March $3,1823$.

2 Senate Doc., 18th Cong., 1st Sess., No. 1, Appendix 1 to Report of Secretary of War.

${ }^{3}$ U. S. Statutes at Large, iii, 526.

4 The requirement of a biennial medical examination was entirely repealed by the act of July 14,1832 . 
in 1827 and 1828, and was finally disposed of by the act of May $15,1828 .^{1}$

An interesting light is thrown upon the difficulties met with in the administration of the invalid-pension laws by a passage in the report of Secretary of War Eaton on November 30, 1829. He said:

Men, at distant periods from the expiration of their service, become blind, and it is reported that, in consequence of being stationed at some particular place, injurious to vision, the ill effect has been produced; they sink into consumptions, and it is traced to a cold caught while in service: in such case the recognized precedents go to establish the right of the party to be placed on the list of pensioners. If this shall continue to be the interpretation given to the laws upon this subject, the list of invalid-pensioners must continue greatly to increase. ${ }^{2}$

The Secretary found that it was easy for applicants who had at any time been in the army to obtain certificates that present disabilities had their origin in services rendered at a remote date. $\mathrm{He}$ was personally opposed to granting pensions on vague and uncertain grounds, and proposed that the law be changed to prevent such a practice. ${ }^{3}$ Congress did not follow his advice in this respect. The difficulty he experienced in administering the invalid-pension law, in its application to the Revolution and the War of 1812 , was many times multiplied when the practice he criticized was applied to the Civil War pension laws.

In administering the Revolutionary service-pension act of 1818 , beginning with 1826 a pension was granted if the claimant's property did not exceed $\$ 300$ in value. The Treasury was in a prosperous condition, and there was a constant tendency to construe the law more liberally as the age and infirmities of the survivors of the Revolutionary army increased. On December 26,1828 , a regulation was made, permitting any claimant having

1 See page 51.

2 Senate Doc., 21 st Cong., 1 Sess., 1829-30, i, No. 1, 29.

s Ibid., No. 9, 1. 
property not to exceed $\$ 960$ to be placed on the pension list. This regulation was revoked in March, 1829, by President Jackson, who considered it to be legislation. It was estimated that this provision would have added 2,000 to the pension list. ${ }^{1}$

About 1830 the revenues of the federal government were far more than enough to meet ordinary expenditures, and rapid progress was being made with the extinction of the public debt. A public problem of the day, discussed in President Jackson's messages, was that of the disposition of surplus revenue. The protective policy was so well established that proposals to lessen the revenue through changes in the tariff were strongly opposed. All circumstances were much in favor of the success of a movement to distribute a part of the surplus revenue by the enactment of more liberal pension legislation.

In his annual message of December, 1829, President Jackson advocated additional pension provisions for the benefit of Revolutionary soldiers. ${ }^{2}$ A bill was introduced with that end in view and passed the House. In the Senate, the measure was indefinitely postponed. In the debate upon it, Senator Hayne of South Carolina, on April 29, 1830, made a notable speech in which he reviewed the course of pension legislation to that time. ${ }^{3}$ While not entirely accurate in details, he showed a good knowledge of the general subject. He characterized the measure under discussion as an attempt to admit to the company of the war-worn veterans of the Revolution a host, many of whom had never even seen an enemy, "mere sunshine and holiday soldiers, the hangers-on of the camp, men of straw, substitutes, who never enlisted until after the preliminaries of peace were signed." Down to the year 1818 , he said, the national pension system had been based upon the principle of disability. The law of that year had abandoned that principle and made service and poverty the basis of pensions. Hayne also called the attention of the Senate to the circumstances attending the passage of the act of

${ }_{1}$ Senate Doc., 21st Cong., 1st Sess., 1829-30, i, No. 9, p. 2.

2 Richardson, Messages and Papers of the Presidents, ii, 456.

3 Benton's Debates, x, 547-555. 
1818 , and to the resultant abuses and fraud. Having the experience afforded by that measure in mind, he urged that it was folly to open a wide door to similar and greater evils.

The latter part of Hayne's speech was noteworthy for its emphatic contention that there was an intimate connection between the proposed increase in pension expenditures and the maintenance of a protective tariff policy. He said that he considered the bill as "a branch of a great system, calculated and intended to create a permanent charge upon the Treasury, with a view to delay the payment of the public debt, and to postpone, indefinitely, the claims of the people for a reduction of taxes, when the debt shall be finally extinguished."

The opposition to an extension of the pension laws prevailed in the twenty-first Congress, but in the next Congress pension bills were introduced into both House and Senate. It was proposed to grant pensions based on service alone without regard to the pecuniary circumstances of the applicant. The House bill was very liberal. Among its supporters Mr. Hubbard of New Hampshire argued that basing pensions on poverty, as under the act of 1818, rather than upon service discriminates against the frugal and industrious and offers "a reward to indolence and dissipation." New legislation was necessary because of the restrictive interpretation of the act of 1818 by the War Department. He thought that the principle of rewarding Revolutionary soldiers was thoroughly established, and favored extending the laws to include all, rich and poor. ${ }^{2} \mathrm{Mr}$. Ward of New York said that, unlike the British pension list, ours was "so little extended we need fear no precedent here."

Southern and Western members opposed the bill vigorously. Mr. Johnston of Virginia charged that "this universal pension bill" was brought forward to aid in large schemes of prodigal

1 For a more extended statement of Senator Hayne's views regarding the
close connection between a lavish pension system and a protective tariff
system, and also regarding the unfavorable financial effect of Revolutionary
service-pension laws upon the Southern states, see Glasson, History of Mili-
tary Pension Legislation in the United States, $41-43$.
2 Register of Debates in Congress, 22d Cong., 1st Sess., viii, Part 2, 1925. 
expenditure which were intended to prevent the reduction of those taxes that pressed heavily on the Southern people. ${ }^{1} \mathrm{Mr}$. Davis of South Carolina regarded the pension bill as an essential and inseparable part of a whole system of revenue and expenditure. He said: "This system is worse than a general tax on industry and property for the relief of the indigent. A poor rate was a tax imposed on the laboring and wealthy for the support of the poor, who are clestitute of employment; but this scheme reversed the order of things, for the effect would be to tax the poor for the support of those who are much wealthier than themselves." ${ }^{2}$ Davis also pointed out that but a small part of the pension expenditures were made in the South, and thus the system unequally distributed the public funds to the great disadvantage of his section. An especially forcible assertion of a connection between the pension bill and the tariff was made by Mr. Bouldin of Virginia, who said that the people south of the Potomac thought that, "for every dollar of revenue raised on them by the present system of duties, to pension the poor soldiers, they are required to pay, and do pay, two dollars to the rich manufacturer." Speaking of pension laws and of all appropriations not of strict necessity, Mr. Bouldin said: "No surprise need be felt at the open-handed liberality of the rich manufacturer in pouring forth his bounty in streams from the public treasury. Well he knows, and closely has he calculated, that whatsoever is by him thus given, returns to him doubled, and that by no indirection, nor after many days, but as the direct result of his benevolence itself."3

Mr. Bell of Tennessee, in opposing the proposed measure said that every step in the pension argument prepared the way for further and indefinite extension. Already the officers of the War of 1812 were demanding recognition, and every advance in the pension policy was an invitation to them and future soldiers to expect the same treatment. Removing the property

1 Register of Debates in Congress, 22d Cong., 1st Sess., viii, Part 2, 2498.

2 Ibid., 2393.

3 Ibid., 2372-2373. 
limitation would not check fraud, but would multiply it; for fraud would then be necessary only to prove the length of service. He thought that the present size of the rolls indicated fraud. ${ }^{1}$

In view of the expressions of members connecting the pension bill with the tariff, it is worthy of note that the tariff act of 1832, to which South Carolina was so bitterly opposed, was before Congress at the same time with the pension bill, and that the new tariff act and the new pension act finally became law within a week of each other. ${ }^{2}$

The pension bill passed the House by an overwhelming majority, but the Senate preferred to consider its own measure. This was less extravagant than that of the House, requiring of applicants a longer period of service in the Revolutionary army. Senator Foot of Connecticut was in charge of the bill. $\mathrm{He}$ presented a report estimating that there could be only 9,000 or 10,000 Revolutionary soldiers living and coming within the terms of the proposed measure. The probable annual expense was estimated at not to exceed $\$ 450,000 .^{3}$ Senator Foot said that the great and powerful argument against the passage of the bill was that it would beggar the Treasury, or, at least, prevent the reduction of unnecessary and oppressive duties. To this he replied that the bill would cost not to exceed $\$ 450,000$, that this sum would be rapidly reduced, and that within five years the expenditure would be merely nominal. He strongly asserted the accuracy of the estimates, which, the committee believed, would

\footnotetext{
1 Register of Debates in Congress, 22d Cong., 1st Sess., viii, Part 2, 24602462.

2 Beginning about 1830, the Southern opponents of the tariff maintained the theory that import duties are in effect direct taxes upon exports. They claimed that a protective tariff was a system of taxation practically levied upon the staple products of the South-cotton, rice, and tobacco, which formed the bulk of the exports. Their theory was based upon the principle that the exports pay for the imports, and that consequently whatever increased the price of imported articles must increase the amount of the exported articles needed to pay for a given quantity of goods. Hence Southerners believed that their section was paying the greater part of the public revenues and that the pension system was operating to distribute these revenues more largely in the Northern states. See Dewey, Financia! History of the United States, 195.
}

3 Senate Doc., 22d Cong., 1st Sess., 1831-1832, i, No. 33. 
exceed the demand. ${ }^{1}$ Henry Clay also spoke in the Senate in advocacy of the claims of the Revolutionary soldiers and denied that "this act of justice to these brave veterans, who still survived of the gallant band which secured our independence, should be identified with the tariff.",

Hayne opposed this bill of 1832, but his speech is not reported. Several Western senators joined the South in the opposition. Senator Robinson of Illinois offered an amendment to include in the bill the "officers and soldiers who served under Generals, Wayne and Clarke in the Northwestern Territory, and in the Indian Wars, after the Revolution." Although Senator Buckner of Missouri thought that a pension system going beyond those who had been injured in the service of their country was bad policy, he said that to pass the bill without the amendment would be an act of injustice to the West. On the theory that the pensions were to be bestowed as a mark of kindness or respect, Buckner said: "There was no reason why this mark of respect should be given to the militia of the East, and not to those of the West. The lands which the Government holds in the West are the fruit of their toils. . . . But to ask the West to pension men fifteen hundred miles distant, not a dollar of which would ever return to the West, was too much." ${ }^{3}$ On the third reading, Western senators against the bill were Benton and Buckner of Missouri, Grundy and White of Tennessee, and Bibb of Kentucky. ${ }^{4}$ The Senate measure having passed, it was accepted by the House and approved by the President on June 7, 1832. ${ }^{5}$

The service-pension act of 1832 took the form of an extension to additional survivors of the Revolutionary army of the full pay for life which had been granted by the act of May 15, 1828 , to certain officers and soldiers who served to the end of

1 Register of Debates in Congress, 22d Cong., 1st Sess., 1831-1832, 926.

2 Ibid., 930.

3 Ibid., $765-766$.

4 Ibid., 933.

${ }^{5} U$. S. Statutes at Large, iv, 529. 
the war. ${ }^{1}$ The new measure granted to all who had completed, at one or more terms, a total service of two years during the Revolutionary War, whether in Continental or state troops, volunteers or militia, or in the navy, and who were not entitled to the benefit of the act of 1828, full pay for life according to rank, not to exceed a captain's pay, to commence from March 4, 1831. All who had completed a total service of not less than six months were to receive for life an annual amount bearing the same proportion to the full pay, as did the length of service to the full two years. By the original terms of the law every one who recer ved its benefits was required to relinquish any pension received by him under any other Revolutionary pension act. But an amendment of February 19, 1833, excepted invalid-pensioners from this restriction, and thus permitted some soldiers to draw both an invalid- and a service-pension.

As in the case of the act of 1828 , the Secretary of the Treasury was originally charged with the execution of the act of 1832 . This duty was speedily transferred to the Secretary of War by the resolution of June 28, 1832. Evidence in support of claims was taken in the form of declarations upon oath before a court of record in the county where an applicant resided. In the case of the regular or Continental troops, it was possible to compare the evidence with the muster rolls in the possession of the War Department, but, in the case of the state troops, volunteers and militia, the Department possessed no rolls except of the state troops of Virginia and the militia of New Hampshire. Therefore, in the consideration of a large number of applications, it was compelled to rely entirely upon the sworn declaration of the claimant and his witnesses, except in so far as his narrative of service could be compared with the known events of the period in which it was said to have been performed. Much importance was attached to traditional evidence, such as a general belief in the neighborhood that the claimant had been a Revolutionary soldier. Such a tradition might be supported by the evidence of

${ }^{1}$ See page 51 . The act of May 15, 1828, was passed as a final settlement of the Revolutionary officers' half pay and commutation claims. 
the nearest clergyman and of other persons of character and standing in the community. It is clear that such provisions were extremely liable to abuse. ${ }^{1}$

Under the loose provisions of the new law, applications were made in surprising numbers. It was thought incredible that there should be so many Revolutionary soldiers alive. On January 23, 1833, Cass, the Secretary of War, reported that 24,260 persons had applied, of whom perhaps one thousand might be rejected. He estimated that the pensions would average $\$ 75.97$ and that it would require $\$ 1,767,000$ to meet the expenditures for one year. Since the pensions were, by the terms of the law, to commence from March 4, 1831, Secretary Cass estimated that to pay them from that date to September 4,1833 , would require $\$ 4,418.000$. $^{2}$ It appeared that the annual charge on the Treasury would be at least four times what had been estimated by Senator Foot's committee.

The new scramble for pensions caused thoughtful men to question the moral and political effect of the whole pension system upon the United States. In discussing a resolution to extend the law of 1832 to those who had fought in the Indian Wars, Mr. Bouldin of Virginia said in the House of Representatives on December 27, 1833, that "the practical effects of the system had been to discourage private industry and lead a large portion of the people of the United States to look to the Treasury as the unfailing spring from which they were to receive every good. The poor, instead of being relieved in their own neighborhoods, were pensioned on the United States."3 Mr. Speight of North Carolina, though opposed to the general law, favored the extension on the ground that the West should be admitted to the "pork-barrel" with the rest. "The moral effect of the system was certainly very bad; almost every soldier in the coun-

\footnotetext{
${ }^{1}$ For regulations for presenting claims under the act of 1832, see Executive Doc., 25th Cong., 2d Sess., 1837-1838, v, No. 118, 84-91.

2 House Doc., 22d Cong., 2d Sess., 1832-1833, No. 68. 2245 .

3 Register of Debates in Congress, 23d Cong., 1st Sess., x, Part 2, 1833-1834,
} 
try was trying to get a pension." 1 Mr. Dickinson of Tennessee also favored the resolution under consideration, but he admitted that perjuries and corruptions of various kinds doubtless attended the granting of pensions, and that the pension system might tend to make patriotism sordid. ${ }^{2}$

As usual a South Carolinian was one of the leaders in the assault on the system. Mr. Pinckney of that state opposed pensions on constitutional grounds, charged that the whole system was "a mere branch of the protective system," and that it increased beyond all limit the power and patronage of the federal government and tended thereby to corrupt the people. He said that by enlisting a host of pensioners the government secured an army dependent on its will and ready to do its bidding. "Pensioners on the bounty of government are only so many political partisans." 3

A Pennsylvanian, Mr. Denny, defended the pension system against the charge that it originated in the protective tariff system on the ground that the pension laws were a continuation of a system and policy which existed before the Constitution. ${ }^{4}$ Another Pennsylvanian, Mr. Chambers, opposed the extension of the system. He thought it dangerous in a Republican government to make military services so much the subject of remuneration and bounty, beyond a provision for disability, thus creating an impression that not only the road to fame and glory but also the highway to the chief offices and to the nation's treasury is to be found in the ranks of the army. He presented statistics computed from the census of 1830 to show that the number of pensioners and unsuccessful applicants was greater than the number of white male citizens in the country old enough, in his opinion, to have served in the Revolution. ${ }^{5}$ The proposition to extend the act of 1832 to the Indian Wars was defeated.

1 Register of Debates in Congress, 23d Cong., 1st Sess., x, Part 2, 2400.

2 Ibid., 2400-2403.

${ }^{3}$ Ibid., 2452-2456.

4 Ibid., 2546.

Ibid., 2650-2653. 
Even John Quincy Adams, who was usually favorable to Revolutionary pension claims, seems to have been disgusted by the scramble for service-pensions. His memoirs, under date of April 7, 1834, contain the following: "Uriah Tracy, thirty years ago, used to say that the soldiers of the Revolution claimants never died-that they were immortal. Had he lived to this time, he would have seen that they multiply with the lapse of time. As petitioners they are more numerous at every session of Congress than ever before. And of late, as some of them have died, their widows have begun to petition; and this day there was a petition from the son of a deceased pensioner praying that the pension may be continued to him."'

One consequence of the pressure of applications for pensions under the act of 1832 was the enactment of new provisions for the administration of the pension laws. On January 3, 1833, the House of Representatives agreed to a resolution, directing the Secretary of War to communicate to the House whether the execution of the act of 1832 required any change in the organization of the Pension Bureau with a view to greater security and more dispatch in the transaction of business. ${ }^{2}$ Secretary Cass replied on January 7 , recommending the establishment of a branch of the War Department to be denominated "The Pension Office."3

In describing the existing pension administration, Cass reported that it was in charge of the Pension Bureau, a branch of the War Department constituted by executive regulations. At the head of the Bureau was a clerk with a salary of $\$ 1600$, and there were employed under him, either temporarily or permanently, sixteen other clerks. The Bureau was divided into five divisions, each of these being in charge of a clerk with others to aid him. Each division considered claims coming from certain states assigned to it. Secretary Cass considered that the obvious defect in the constitution of the Office was the want of legal

1 Memoirs of John Quincy Adams, ix, 124.

${ }^{2}$ House Journal, 22d Cong., 2d Sess., 1832-1833, 127.

${ }^{3}$ House Doc., 22d Cong., 2d Sess., 1832-1833, i, No. 34, pages 1 to 3. 
responsibility and of efficient control in the head of the Bureau. "His duties are not defined by law, nor are his acts recognized by law. While, in fact, controlling the disbursements of near two million five hundred thousand dollars annually, he is still known upon the statute book as a clerk only with a compensation attached to that situation, and without the slightest allusion to the powers and duties he actually exercises."

Cass favored a reorganization of the Bureau in order to deal with the great amount of business (over 24,000 claims had been presented under the act of 1832 ) promptly and with proper safeguards against fraud. Under the laws then existing the Secretary of War was the only responsible officer in the administration of the pension acts, but he pointed out that it was physically impossible for the Secretary to examine into the details. $\mathrm{He}$ advocated the establishment by Congress of a branch of the War Department, under the name of the Pension Office, with an officer at its head to be known as the Commissioner of Pensions. This responsible officer would administer the laws under the general direction of the Secretary of War. Congress followed the recommendation of the Secretary in an appropriation act of March 2, 1833, ${ }^{1}$ which provided for a Commissioner of Pensions, to be appointed by the President and Senate, and to receive an annual salary of $\$ 2,500$. It was made the duty of the Commissioner to "execute, under the direction of the Secretary of War, such duties in relation to the various pension laws, as may be prescribed by the President of the United States." The new office was created to continue only until the expiration of the next Congress. ${ }^{2}$

$1 U$. S. Statutes at Large, iv, 622.

2 The act of March 3,1835, continued the office of Commissioner of Pensions for the further term of two years and also transferred from the Treasury Department to the War Department the duty of executing the provisions of the act of May 15, 1828, for the benefit of the Revolutionary officers and soldiers who served to the end of the war. Further legislation continued the office of Commissioner of Pensions from time to time until the act of January 19,1849, which authorized the indefinite continuance of the office until further legislation by Congress. By the act of March 3, 1849, establishing the Department of the Interior, the Pension Office became a bureau of that department. The Secretary of the Interior was given super- 
The first Commissioner of Pensions was James L. Edwards, who had for some fifteen years been the clerk in charge of the Pension Bureau of the War Department. ${ }^{1}$ Commissioner Edwards had not long assumed his new responsibilities before he was called upon to deal with disclosures of startling and widespread frauds under the act of 1832 . The worst cases came to light in the fall of 1834. Thirty-seven indictments for forgery and perjury in the prosecution of pension claims were found by the grand jury in the federal court at Clarksburg, Virginia. Among the attorneys implicated were the commonwealth's attorney for Lewis County and a member-elect of the legislature from the same county. They both fled, and were supposed to have gone to the "province of Texas." In Vermont there were thought to be 200 fraudulent cases. Claims were made on behalf of fictitious persons and actually admitted. Estimates of the government's losses by fraud in that state ranged from fifty thousand dollars to very much larger sums. The principal perpetrator of the Vermont frauds was Robert Temple, formerly agent for paying pensions, president of the Bank of Rutland, and a man of wealth and prominence in the state. Alarmed at an order for the publication of the pension list, he went to Washington and attempted to bribe a clerk to alter the list in order to

visory and appellate powers in relation to all the acts of the Commissioner of Pensions. The Bureau of Pensions remains today a part of the Department of the Interior, and the Secretary of the Interior continues to exercise important supervisory and appellate powers in pension matters. While in the earlier history of the federal government the administration of pension laws was generally entrusted to the Secretary of War, there were enacted many pension provisions applying solely to the navy. Such acts were executed under direction of the Secretary of the Navy until 1840, when the pension business transacted in the Navy Department was transferred to the office of the Commissioner of Pensions. The Secretary of the Navy was then given a share in the supervision of the Pension Office until the Department of the Interior was created in 1849. An act of January 20, 1843, imposed upon the Commissioner of Pensions such duties in relation to the execution of the laws granting military bounty lands as might be assigned to him by the Secretary of War with the sanction of the President. These duties became for a time very important.

1 It is worthy of note that Commissioner Edwards remained in office until 1850.

${ }^{2}$ Richmond Enquirer, Oct. 28, 1834 ; Niles' Register, xlvii, 97, 147. 
conceal his crimes. ${ }^{1}$ The clerk disclosed the affair to his superiors, who took steps to secure further evidence. Temple, learning that he was about to be arrested, committed suicide at his home in Vermont. Temple's method was to trump up claims on behalf of soldiers long dead or of persons who never existed. Through perjury and the collusion or carelessness of local magistrates, these claims were made to appear valid and were admitted. Then by forgery Temple was able to collect the pension payments as they were made. ${ }^{2}$ Other exposures of similar frauds were made in Kentucky, New York, and Ohio. ${ }^{3}$

Commissioner of Pensions Edwards, in his annual report on November 7,1834 , referred in scathing terms to the frauds that had been perpetrated by men of high standing in society, whose official stations and respectability placed them far above suspicion. He said that steps had been taken to punish the offenders and that, in some instances, successful prosecutions had resulted in the confinement of the criminals in state prisons. In other cases, they had fled from justice. Wherever there was a prospect of recovering money improperly paid out, a suit had been commenced.

In describing the bold character of the frauds, the Commissioner said:

It has been ascertained that papers have been presented at this Department purporting to contain proof of Revolutionary service, taken in open court, bearing the official seal of the clerk of the court, and duly certified by him, when, in fact, the persons in whose behalf the claims were made, never had any but an imaginary existence. In some instances, the claims have been admitted, and money has been

1 The Senate ordered the publication of the list of pensioners, classified by states and counties, and the transmission of each state's list to its courts of record. This was done to facilitate the detection of cases of fraud. Senate Journal, 23d Cong., 1st Sess., 1833-1834, 404.

2 For accounts of the Vermont frauds, see Vermont Patriot and State $\mathrm{Ga}$ zette, Oct. 13, 1834; Richmond Enquirer, Oct. 24, 1834; Niles' Register, xlvii, 105-106 (Excerpts from several current newspapers).

${ }^{3}$ House Reports, 23d Cong., 2d Sess., 1834-1835, i, No. 4. Niles' Register, xlviii, 225 ; New York Sun, July 3, 1835. 
paid. In other cases, money has been paid to a period after the time when the pensioners died; and this last mentioned description of fraud was effected by means of falsifying the certificates of a clerk of a court of record.

After a detailed description of the fraudulent methods used in some particular instances, the Commissioner recommended the appointment of officers in each state and territory "for the purpose of examining in person all pensioners and applicants for pensions." $\mathrm{He}$ reported that there were 27,978 pensioners on the rolls under the act of 1832 , and that the amount sent to agents in 1834 for payments under this act was about $\$ 2,325,000$. The whole national pension roll contained about 43,000 names. ${ }^{1}$

There were also discussions of the pension frauds in the annual report of the Secretary of War, ${ }^{2}$ and in the President's message of December, $1834 .^{3}$ Secretary Cass pointed out that, as these disclosures had been the result of accident, it was impossible to judge to what extent frauds might have been committed. President Jackson agreed with Commissioner Edwards as to the desirability of an actual inspection of the pensioners in each state. The object of this inspection should be twofold, to look into the original justice of the claims, and to ascertain, in all cases, whether the claimant was living, and this by actual personal inspection. In the House of Representatives, that part of the President's message which dealt with the pension frauds was referred to the Committee on Revolutionary Pensions. The same committee was also instructed to inquire into the expediency of requiring the publication semi-annually in various newspapers in the several states of the names and residences of all persons represented to be living in said states who were on the pension roll. ${ }^{4}$

The House Committee reported that great and extensive frauds

${ }^{1}$ For the report of Commissioner Edwards, see Executive Documents, 23d Cong., 2d Sess., 1834-1835, i, No. 2, 273-280.

2 Ibid., 36-38.

${ }^{3}$ Ibid., 18-19.

4 For the resolutions instructing the committee and for its report, see House Reports, 23d Cong., 2d Sess., 1834-1835, i, No. 37. 
had undoubtedly been committed and that men in the highest walks of life had secured large sums of money from the Treasury by means of false papers, gross acts of forgery, and wilful periury. It was pointed out that, although the advocates of the act of 1832 had estimated that 10,000 persons would be benefited by its provisions, the number of appiicants at the Pension Office under this law already exceeded 32,900. Fifty-two years had nearly passed away since the peace of 1783 . A soldier who entered the army at the age of sixteen in the last year of the war was, if living, 68 years old in 1835; if such a soldier enlisted at the beginning of the Revolution, he was at least 75 years of age. Could there be some 40,000 of these old Revolutionary soldiers still living ?

The committee recommended that in those states where there were county newspapers publication should be made of the name of each pensioner residing in the county, his place of residence, his age, the amount of his pension, and the name of the agent who drew up his papers and presented them to the Pension Office. Where county newspapers were not available for publication of the above facts, the committee thought it highly necessary and proper that there be a personal investigation of the pensioner and an investigation of the merit of his claim. It was recommended that the Secretary of War be given discretion to adopt one or the other method of detecting frauds as the circumstances of particular cases warranted. However, in view of the honesty of the majority of the pensioners, the committee did not favor the suspension of any pension payments until after an inspection had been made. Notwithstanding the committee's recommen-

\footnotetext{
1 In the fall of $1834,511 / 2$ years after the close of the Revolutionary War, there were approximately 40,000 Revolutionary pensioners under the invalid acts, the act of 1818, and the act of 1832. The Pension Bureau has published an estimate that the total of individual enlistments in the Revolutionary army, including militia, was 184,038 . The pensioners in 1834 were about 22 per cent of this number. Individual enlistments in the Civil War are estimated at a total of 2,213,363 in the Union armies. Fifty years after the conclusion of hostilities, on June 30,1915 , there were 396,370 survivors on the pension roll, or 18 per cent.
} 
dations, Congress failed to enact measures for the reform of the pension system. ${ }^{1}$

In this study of Revolutionary pension legislation, little provision has thus far been found for the widows or children of deceased soldiers. Before the close of the Revolution, by the resolution of August 24, 1780, half pay for seven years was promised to the widows or orphans of such Revolutionary officers as had died, or should die, in the service, but the widows of noncommissioned officers and soldiers were not included in the benefits of the measure. The resolution of 1780 expired before the inauguration of the federal government, but was renewed for two years by the act of March 23, 1792. ${ }^{2}$

Excepting sundry provisions for the payment of pension money, accrued and unpaid at the death of pensioners, to their widows, children or legal representatives, there was no general legislation for the benefit of widows of Revolutionary officers and soldiers from 1792 to 1836 . Then the continued existence of a large surplus in the Treasury created conditions favorable to the success of propositions for the granting of pensions to Revolutionary widows. Such measures had been brought forward at intervals, but none was successful until the passage of the act of July 4, 1836. ${ }^{3}$ This act gave a long lease of life to the Revolutionary pension list by inaugurating, fifty-three years after the close of the war, a series of measures pensioning the widows of Revolutionary soldiers. Deaths among the surviving soldiers would soon have made the pension list so small as to be negligible, but the various grants to widows continued pension payments on account of the Revolutionary War down to comparatively recent times.

1 An appendix to the House Committee's report mentions four classes of frauds: (1) Claims asserted in the names of actual Revolutionary soldiers who were dead. (2) Claims in the names of persons not on the Revolutionary army rolls, and where no such persons existed at the time the declarations purported to have been made. (3) Cases where the pensioners died after the pensions were granted, and their allowances were drawn by false vouchers.

(4) Overstatement of the services of claimants in their declarations and in the testimony supporting them.

${ }^{2} U$. S. Statutes at Large, i, 243.

3 Ibid., v, 127. 
The Revolutionary widows' pension act of 1836 provided that if any Revolutionary soldier, who would have been entitled to a pension under the act of June 7,1832 , had died, leaving a widow whose marriage took place before the expiration of his last period of service, such widow, so long as she remained unmarried, should be entitled to receive the pension which might have been allowed to her husband, if living at the time the act of 1832 was passed. This law pensioned about five thousand widows who were the wives of soldiers while the Revolutionary War was in progress. Nearly one hundred of these war time widows were still living in 1858 , seventy-five years after the close of the Revolution. ${ }^{1}$

The act of 1836 was followed by a long series of laws for the benefit of widows that grew more and more comprehensive in terms as the years passed by. It would not be profitable to follow the details of this legislation. We may say, in short, that provision was next made for widows who married Revolutionary soldiers between 1783 and 1794, later for those who married prior to 1800 , and finally for such widows as were otherwise entitled regardless of the date of marriage. The general tenor of these laws was to grant pensions to widows during widowhood equal in amount to the allowances to which their husbands would have been entitled under existing laws, if living. An act of July 27, 1868, provided that the widows of Revolutionary soldiers and sailors receiving a less sum should thereafter be paid at the rate of eight dollars per month. ${ }^{2}$ The last public law provision specifically for the benefit of Revolutionary widows was contained in the War of 1812 pension act of March 9, $1878 .^{3}$ It authorized the placing upon the pension roll of any widow of a Revolutionary soldier who served for fourteen days or in any engagement at the monthly rate of eight dollars. The few surviving Revolutionary widows shared the benefits of the act

${ }^{1}$ Report of Secretary of Interior, Senate Doc., 35th Cong., 2d Sess., 18581859 , i, 85.

$2 U$. S. Statutes at Large, $\mathrm{xv}, 235$.

3 Ibid., $\mathrm{xx}, 27$. 
of March 19, 1886, which increased the pensions of all widows then on the pension roll of the United States to twelve dollars per month.

After the service-pension act of 1832, there were but few minor provisions for the benefit of Revolutionary soldiers. From time to time attempts were made to secure arrears of pensions on account of Revolutionary services. On April 2, 1862, an act became law which limited the allowance of such claims to the parties who rendered the service or to their widows, and excluded all heirs from any claim to arrears unless the right to pension was established during the lifetime of the person on whose account the application was made. As a mark of special recognition, a law of April 1, 1864, granted $\$ 100$ additional annual pension to each of the surviving soldiers of the Revolution then on the pension roll. ${ }^{1}$ By November of that year, seven of the number who were the intended recipients of this special bounty had died at an average age of about one hundred years, and but five were still living. ${ }^{2}$ For the benefit of these five, Congress passed the private act of February 27, 1865, granting each of them a gratuity of $\$ 300$ annually during the remaining years of life in addition to the pensions already being paid to them according to law. ${ }^{3}$ By June 30, 1867, all the Revolutionary soldiers on the pension rolls had died. During the following fiscal year two other persons were pensioned as Revolutionary soldiers by special act at $\$ 500$ per annum. Daniel F. Bakeman, the last survivor, died on April 5, 1869, aged 109 years, 6 months, 8 days.

The names of 887 Revolutionary widows remained on the pension list on June 30,1869 , although the actual number living was without doubt somewhat less by reason of unreported deaths. In his report for the fiscal year 1870, the Commissioner of Pensions stated that of 727 Revolutionary widows 51 were reported to be between 60 and 70 years of age, 11 were between 50 and 60 years, and two were under 50. Mrs. Louisa Porterfield, widow

${ }^{1} U$. S. Statutes at Large, xiii, 39.

2 Report of the Commissioner of Pensions, 1864.

${ }^{3} U$. S. Statutes at Large, xiii, 597. 
of Richard Porterfield of Knoxville, Tennessee, was said to be "forty or forty-five years of age, strong and able-bodied." This was eighty-seven years after the end of the Revolutionary war, and the presence of these widows on the pension roll illustrates the effect of pensioning the widows of soldiers in cases where the marriage took place at a date remote from the time when the military service was performed. Young wives of aged veterans carried the Revolutionary pension list over into the twentieth century. In 1906, 123 years after the close of the Revolution, there still remained one widow of a Revolutionary soldier on the pension list, Esther S. Damon of Plymouth Union, Vt., 92 years of age. ${ }^{2}$ Even after the death of this venerable widow on November 11, 1906, there remained for a few years on the pension roll a few aged daughters of Revolutionary soldiers who had been pensioned by special acts of Congress.

From the invalid-pension resolution of August, 1776, to the last provision for widows in March, 1878, there was over a century of Revolutionary pension legislation. First invalidpension laws were passed for the benefit of officers and privates. Service-pensions of half pay for life were promised to officers who served until the end of the war, but, on account of bitter opposition, the officers received instead of the half pay a gross sum in commutation certificates. In 1818 a precedent was established for service-pensions to volunteer armies by the grant of such pensions to the indigent veterans of the Revolution. A more liberal law was passed in 1832, and service-pensions were granted to the Revolutionary soldiers regardless of income or property. The widows of Revolutionary soldiers (with the exception of the widows of officers), received no pensions until 1836. As death decreased the number of survivors on the pension roll, the laws for the benefit of widows were from time to time made more comprehensive. The cost of Revolutionary invalid-pensions was very small as compared with the service-

${ }^{1}$ Reports of Commissioner of Pensions, 1867, 1868, 1869, 1870.

2 Ibid., 1905, 1906, 1907. 
pensions and the widows' pensions. With respect to this alone of our wars, the complete effects of all pension legislation have been realized-although the pension record of the War of 1812 will also be complete in a few years.

The manner of keeping the records during the early years of the federal government makes it impossible to state the exact number of Revolutionary soldiers who were granted invalidpensions. There were probably not more than two or three thousand. In his report for 1874, Commissioner of Pensions Baker gave a summary of the results of Revolutionary service-pension legislation. ${ }^{1}$ He reported that 20,485 Revolutionary soldiers were pensioned under the act of 1818, 1,200 under the act of May 15, 1828 , and 33,425 under the act of 1832 . The average age of those pensioned under the act of 1832 was $74 \mathrm{I} / 2$ years. Under the three laws the total is 55,110 . Elsewhere in the same report (page 678) the number of Revolutionary service-pensioners is given as 57,623 , perhaps including special act pensioners and restorations to the roll under the act of March 1,1823 . The above statistics probably include many duplications. Thousands who were pensioned under the act of 1818 were dropped from the rolls because they were not indigent. Many were again pensioned under later legislation, especially under the act of 1832 . The number of original soldiers' and sailors' claims allowed on account of the Revolutionary War is given in the report of the Commissioner of Pensions for 1915 as 52,504. ${ }^{2}$

Commissioner Baker, in his report for 1874, gave the cost of the Revolutionary service-pensions to the death of the last survivor in 1869 as $\$ 46,177,845$. Estimating the Revolutionary invalid-pensions at from three to four million dollars, the total pension disbursements to Revolutionary soldiers amounted in round numbers to about $\$ 50,000,000$. The Commissioner of Pensions says in his report for 1915 that 22,644 original widow

${ }^{1}$ House Ex. Doc., 43d Cong., 2d Sess., 1874-1875. Report of the Secretary of the Interior, i, 667 and 678 .

2 See Report of the Commissioner of Pensions for 1915, 18, 29, 30. 


\section{FEDERAL MILITARY PENSIONS IN THE UNITED STATES}

claims were allowed on account of the Revolutionary War. ${ }^{1}$ From 1836 to 1874 the Revolutionary widows received $\$ 19,604$,000 . The payments to such widows after 1874 , together with the early half pay to the widows of officers, probably brought the total to $\$ 20,000,000$, or slightly more. Thus the total payments for Revolutionary pensions to soldiers and widows amounted to about $\$ 70,000,000$, which is the estimate of the Pension Bureau. The entire pension cost of this war was considerably less than half of the present cost of our national pension system for a single year.

However, Revolutionary pension legislation was important for the precedents it established. In miniature, its history shows most of the conditions which surrounded the passage and administration of later pension laws. Conditions of Treasury surplus encouraged the enactment of expensive service-pension provisions, thereby making precedents immensely costly when applied to later wars. There were many Southern members of Congress who asserted that there was a close connection and sympathy between the supporters of a lavish pension system and the supporters of a protective tariff which produced the necessary revenues. As in later days, it was felt that the pensioners and their friends were a political force to be reckoned with. Loose and extravagant legislation brought frauds, public indignation, and attempts at reform. There was a widespread feeling that the pension system had an important influence in lowering the moral tone and lessening the independence of large numbers of citizens. In many cases pension frauds were discovered which involved criminal acts of a grave character on the part of persons who had been respected and trusted. There were indications that many more frauds were committed than came to light. Like the Civil War pension laws-although for different reasons - Revolutionary pension legislation operated to the disadvantage of the South in the distribution of the public revenues. As a

1 Figures given in the report of the Commissioner of Pensions for 1874 are misleading due to duplications in the class of widows married prior to 1794 . Pensions were at first granted to this class of widows for a term of years and continued by later laws. 
whole the experience of the country with the Revolutionary pension laws should have furnished much valuable guidance and warning in the framing and administration of Civil War pension laws, but, as a matter of fact, this early experience was practically ignored. 


\section{CHAPTER IV}

\section{Regular Army and Navy Pensions}

Pension provisions for the regular army were included in the act of April 30, 1790, to regulate the military establishment of the United States. ${ }^{1}$ Later laws fixing the military peace establishment, or raising volunteers or militia for various purposes, commonly included a section dealing with the matter of pensions. Such provisions were in the aggregate of small financial importance. Fundamental provisions applying to regular army pensions before the Civil War are found in the act of March 16, $1802,{ }^{2}$ and in Section 4 of the act of April 25, 1808. ${ }^{3}$ Until 1816. the invalid-pension rate for total disability of officers was not to exceed one-half of the monthly pay, and for noncommissioned officers and privates not to exceed five dollars per month. The act of April 24, 1816, however, increased the allowance for noncommissioned officers and privates to eight dollars per month, and also increased the rate for the lower grades of commissioned officers. ${ }^{4}$ In cases of partial disability, a proportionate allowance was made. For many years, the only provision for widows and orphans was a grant of half pay for five years to the widows, or children under sixteen years of age, of commissioned officers in the troops of the United States, dying in the service in consequence of wounds received.

Since the Civil War the officers and soldiers of the regular army have enjoyed the benefits of the very liberal general law pension system which is described in detail in Part II, Chapter I. Until 1904 the Pension Bureau included the expenditures for regular army pensions with the Civil War expenditures under

1 U. S. Statutes at Large, i, 121.

2 Ibid., ii, 132.

3 Ibid., ii, 491.

4 Ibid., iii, 296. 
the general law. Since that time they have been separately stated, and a table on page 146 shows the number of regular army pensioners and the amount paid them from 1904 to 1916 inclusive.

In the United States the retirement system for the officers and enlisted men $^{1}$ of the regular army has not been ordinarily treated as a part of the national military pension system. In the view of the law, the retired officers and men remain a part of the army, and the amounts allowed them are considered army pay. However, this retirement pay at the close of a long military career is analogous to the service-pensions of European armies. Persons on the retired list of the army, navy, or marine corps of the United States are not ordinarily permitted to receive pensions. ${ }^{2}$

From time to time, the services of the regular army have been supplemented by militia and volunteers called upon for some special emergency. Prior to the Civil War, the provisions of the act of March 16. 1802, were frequently extended to such emergency forces. In time of war the widows and orphans of private soldiers of both the regular army and the militia were usually allowed half pay for five years in the same manner as the widows and orphans of commissioned officers. Upon its expiration, this half pay was often continued from time to time. Eventually, the act of June 3,1858, granted to all those surviving widows and minor children, who had been allowed five years' half pay under the provisions of any previous general law, a continuance of such half pay to commence from the date of the last payment. ${ }^{3}$ This pension was to be paid to widows during life, and where there was no widow, or in case of her death or remarriage, to the minor children while under the age of sixteen years.

1 Enlisted men may retire after thirty years' service with seventy-five per cent of the pay and allowances they are receiving at the time of retirement. See act of March 2, 1907, U. S. Statutes at Large, xxxiv, 1217.

2 Act of March 3, 1891, U. S. Statutes at Large, xxvi, 1082.

${ }^{3}$ U. S. Statutes at Large, xi, 309. 


\section{Navy and Privateer Pension Funds}

While, to a large extent, the general pension laws of the United States have applied to army and navy alike, there was developed early in our history a special plan for paying navy pensions out of funds derived from the sale of prizes taken at sea. Navy pension laws were long principally concerned with the formation, administration, and use of the funds known as the navy and privateer pension funds. These funds were administered apart from the general pension system until after the Civil War, and therefore require separate consideration.

Under the Continental Congress provisions had been made for the payment of part of the proceeds of prizes taken by the navy to disabled officers and sailors and to the widows and children of the slain. Such payments of prize money on account of disability or death were to be deducted from the half pay ordinarily allowed. ${ }^{1}$ From the establishment of a naval armament in 1791 up to about 1800 , disability-pension provisions were made for the officers, marines, and seamen of the navy in the same manner and at the same rate as for the regular army. Laws of 1799 and 1800 , for the government of the navy of the United States, established a navy pension fund, which was to be made up of the government's share of money accruing from the sale of prizes taken at sea by vessels of the navy. ${ }^{2}$ This fund was intended to provide half pay pensions for life, or during disability, to all disabled officers and men of the navy. If it should not prove sufficient for the purpose, the public faith was pledged to make up the deficiency. The Secretary of the Navy, the Secretary of the Treasury, and the Secretary of War were made commissioners to manage the fund, with the duty of presenting an annual report of their operations to Congress.

In January, 1811, the fund consisted of $\$ 132,700$ in government stock and $\$ 60,000$ in bank stock. There were 93 pension-

${ }^{1}$ Journals of the Continental Congress, Nov. 28, 1775, iii, 386-387; August $26,1776, \mathrm{v}, 703$.

2 U. S. Statutes at Large, i, 709; ii, 53. 
ers who received about $\$ 7,000$ annually. ${ }^{1}$ The activities of the War of 1812 brought about a rapid growth of the fund, and the income from investments was considerably in excess of the outlay for pensions. In addition to the invalid-pensions which had been a charge on the fund, laws of 1813 and 1814 granted half pay pensions for five years to the widows and orphans of those who should die by reason of wounds received in the line of duty in the navy. On January 15,1817 , the fund owned $\$ 495,000$ in government stock, $\$ 91,600$ in bank stock, and $\$ 73,000$ of prize and other money was due the fund. ${ }^{2}$ There were at that time 327 navy pensioners who received annually $\$ 27,600$.

In 1817 the provision of half pay pensions for five years to widows and orphans was broadened to include cases where the death of the officer or seaman occurred "in consequence of disease contracted or of casualties or injuries received" as well as in consequence of wounds. This provision made too large a demand upon the fund and was repealed in $1824 .^{3}$

As the half pay pensions for widows and orphans expired from time to time, they were usually renewed for periods of five years. After 1813, the laws on this subject vere numerous and complicated but not of sufficient importance to warrant a detailed account of them.

The history of the navy pension fund was not without difficulties and scandals. In their report for 1815 , the commissioners of the fund complained of delays on the part of officers who were charged with the prosecution and sale of prizes. Arrearages of prize money due the fund were unpaid, and it was difficult to secure a punctual and faithful accountability on the part of the officers who held the money in their possession. ${ }^{4}$ Congress soon after passed the act of April 16,1816, which made detailed provisions for the collection and payment into the navy pension fund

1 American State Papers, Naval Affairs, i, 229-230.

2 Ibid., i, 433.

${ }^{3}$ Concerning navy fund pensions to widows and orphans, see American State Papers, Naval Affairs, iv, 489.

4 Ibid., i, 380-381. 
of the government's share of prize money, and furnished means to enforce obedience to the law on the part of negligent or dishonest officials. In 1832 the Secretary of the Navy was made sole manager of the fund. The property of the fund was to be held in custody by the Treasurer of the United States, and the Secretary of the Navy was directed to invest the cash balance on hand, and all money that might arise to the fund, in stock of the bank of the United States.

During a large part of its history, the accounts of the navy pension fund were kept in so irregular a way that it would baffle an expert accountant to prepare a complete and accurate statement of its financial history. ${ }^{1}$ A report of the Navy Department of December 6, 1831, presents the best available information regarding the fund from its establishment to that date. ${ }^{2}$ A summary of the facts follows:

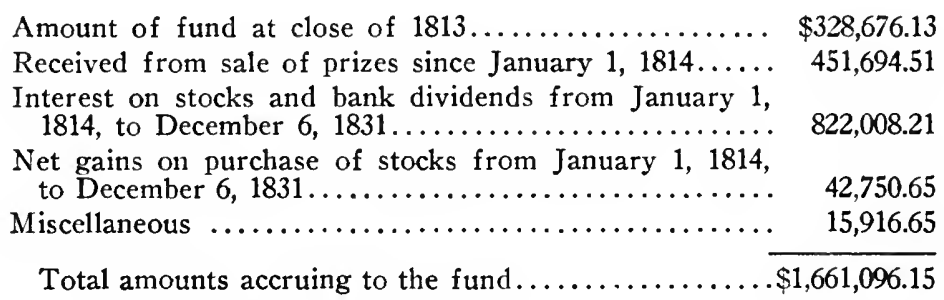

Up to the same date, there had been paid out of the fund for pensions $\$ 584,396.32$. A loss of $\$ 99,502.60$ had been suffered on account of the cost of stock owned by the fund in the Columbia Bank which failed. On December 6, 1831, the fund owned United States and bank stocks of the nominal value of $\$ 1,003$,880.38 and cost value of $\$ 980,359.33$. Its income in 1831 was $\$ 43,217.07$, and the expenditures for pensions and incidental expenditures in that year were about $\$ 30,000$. In 1830 there were 463 invalid-pensioners of the navy and 73 widows and minors.

1 An account of the irregularities in the management of the navy pension fund may be found in American State Papers, Naval Affairs, iii, 499-540.

2 American State Papers, Naval Affairs, iv, 44-45. 
The fact that the income of the fund in the early thirties was much more than adequate to the demands upon it, and that the number of navy invalid-pensioners was declining, led to a liberalization of the navy pension laws which was eventually disastrous to the fund. An act of June 30,1834, restored the provisions of law which prevailed between 1817 and 1824 by granting pensions to the widows of officers and sailors who died in the naval service since January 1, 1824, or who might thereafter die, by reason of disease contracted, or casualties or injuries received, while in the line of duty. ${ }^{1}$ On November 1, 1835, the capital of the fund was $\$ 1,160,262.28$, and the income for 1835 was $\$ 66$,083.36. There were 306 invalid-pensions charged upon the fund, amounting annually to $\$ 23,842$, and 136 widows pensions to the annual amount of $\$ 30,241$. The act of 1834 had considerably increased the number of widow pensioners, and there were some widows of officers who received comparatively large amounts.

The navy pension fund was finally exhansted as the result of the passage under extraordinary circumstances of the act of March 3, 1837, which seems to have been on a small scale similar to the Civil War Arrears Act of 1879. The Secretary of the Navy had prepared a new plan for navy pensions which had passed the Senate. But near midnight of the last day of the session another bill was substituted as an amendment in the House of Representatives on the plea of retrenchment and economy. $^{2}$ This was at first disagreed to by the Senate, but, upon the insistence of the House, it was finally accepted and became law. ${ }^{3}$

This act of March 3, 1837, granted pensions to the widows, and if there were no widows, to the children under twenty-one years of age, of all officers, seamen, and marines, who had died, or might thereafter die, in the naval service, to be paid from the

${ }^{1}$ For a report showing the effects of the act of 1834 , see American State Papers, Naval Affairs, iv, 863-864.

2 Paper accompanying the report of the Secretary of the Navy to the President, Nov. 30, 1839. Senate Doc., 26th Cong., 1st Sess., i, 1839-1840, Doc. No. $1,600-601$.

${ }^{3}$ Cong. Globe, 24th Cong., 2d Sess., 218, 219, 220, 221. 
dates of their deaths, and to be half pay of the navy as such pay was on January 1, 1835. It also provided that pensions already granted, or to be granted, to invalids, should be paid from the time when they were disabled. All inconsistent laws were repealed. Thus the widows and children of all officers and seamen who died in service were pensioned, regardless of the cause of death, and arrears were granted going back to the date of death. ${ }^{1}$

There were some cases under the act of 1837 in which arrears of $\$ 6,000, \$ 7,000$, and $\$ 8,000$ were paid. The number of navy pensioners was increased to 847 in 1838 at an annual expenditure of $\$ 103,120$. Arrears payments soon consumed nearly $\$ 600,000$. Between March 3, 1837, and October 1, 1838, about $\$ 725,000$ of the invested capital of the fund was sold, and the proceeds, with the interest and dividends on the capital, were applied to the payment of pensions and arrears. ${ }^{2}$ In 1840 the navy pension business was transferred to the office of the Commissioner of Pensions, and the navy pension fund was finally exhausted in 1842. From that time until the Civil War, navy pensions were paid by annual appropriations made by Congress.

Although the navy pension fund itself had disappeared, the laws establishing it remained upon the statute books and again came into force during the Civil War. For the sake of continuity of treatment, the latter part of the history of the fund will be given here rather than in the chapters on Civil War pensions.

With the opening of the Civil War, large sums of money began to come to the government from the sale of prizes taken at sea. Congress expressly sanctioned the reestablishment of the navy pension fund by act of July 17, 1862. ${ }^{3}$ By October 1, 1864, Commissioner of Pensions Barrett reported that the fund amounted to about $\$ 6,056,000$ of which more than $\$ 4,000,000$ had been

$1 U$. S. Statutes at Large, v, 180.

${ }^{2}$ For details regarding the financial effects of the act of March 3. 1837, see reports of the Secretary of the Navy for 1837 and 1838 .

${ }^{3} U$. S. Statutes at Large, xii, 607. 
paid in during the year preceding that date. Invested at six per cent, the fund would produce an annual income of over $\$ 363,000$. Navy pensions of all classes on June 30,1864 , required an annual expenditure of only $\$ 179,000$.

In view of the large amount needed annually for the payment of army pensions, Commissioner Barrett proposed that, following the analogy of the navy pension fund, a certain proportion of the money accruing from the sales of abandoned or confiscated property or land should be similarly used for the creation of an army pension fund. The Secretary of the Interior commended his suggestion to the consideration of Congress, but it was not acted upon. ${ }^{1}$

The act of July 17,1862 , charged only navy invalid-pensions upon the fund. They were paid from the office of the Commissioner of Pensions at the regular rates established by the Civil War pension laws. Congress, by resolution of July 1, 1864, directed the Secretary of the Navy to invest the fund in registered securities of the United States. Its nominal income was greatly increased by the exchange of the coin interest on these securities for legal currency of the United States at the existing rate of premium on gold. ${ }^{2}$ The income thus created was so far in excess of all demands that Congress, in 1866, charged upon the fund the payment of pensions to navy widows and dependent relatives. ${ }^{3}$ By 1867 receipts from prize money and surplus income had increased the capital amount to $\$ 13,000,000$, and there was an uninvested balance of $\$ 229,000$.

Congress provided in 1867 that seamen and marines who have served twenty years in the navy and are, from age or infirmity, disabled from sea service may receive a half pay allowance from the navy pension fund in lieu of being provided with a home in the United States Naval Asylum at Philadelphia. The same law authorized the Secretary of the Navy, upon the favorable report

\footnotetext{
${ }_{1}$ Concerning the management of the fund, see the annual reports of the Commissioner of Pensions for 1863, 1864, 1865, and 1867.

$2 U$. S. Statutes at Large, xiii, 414.

3 Ibid., xiv, 2-3.
} 
of an examining board, to make an allowance from the fund to disabled sailors and marines who have served for a period of not less than ten years. ${ }^{1}$ By the naval appropriation act for 1870 , the future support of the Naval Asylum at Philadelphia was made a charge upon the income of the navy pension fund. ${ }^{2}$

The naval prizes of the Civil War built up the fund to $\$ 14$,000,000 invested in United States bonds. In 1868 Congress reduced the rate of interest on the fund to three per cent payable in lawful money. In consequence of the great increase in expenditures for Civil War pensions, the income of the fund has been since 1870 inadequate to pay all navy pensions. A provision of the act of 1862 , pledging the public faith to make up any deficiency, has been brought into operation. The fund was somewhat increased by the investment of prize money received by the government on account of the War with Spain. In its present condition, the part of the income of the fund available for the payment of pensions is only a small percentage of what is required for that purpose. As has been previously stated, a portion of the income of the fund is used for the support of the Naval Asylum at Philadelphia. Following are the statistics of the use of the income of the fund in the payment of pensions for the last seven years :

Total Annual Payments for Navy Pensions, and the Contribution of the Navy Pension Fund ${ }^{3}$

\begin{tabular}{|c|c|c|}
\hline Fiscal Year & $\begin{array}{l}\text { Payments for } \\
\text { Navy Pensions }\end{array}$ & $\begin{array}{l}\text { Available Income } \\
\text { from the } \\
\text { Navy Pension Fund }\end{array}$ \\
\hline 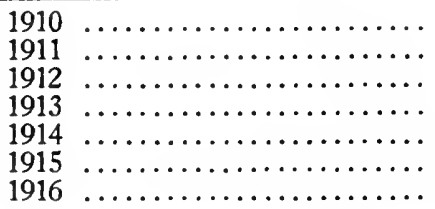 & $\begin{array}{r}\$ 5,335,457 \\
5,392,485 \\
5,319,822 \\
6,021,685 \\
6,047,904 \\
5,810,475 \\
5,706.703\end{array}$ & $\begin{array}{r}\$ 362,299 \\
378,159 \\
367,009 \\
400,066 \\
356,529 \\
353,849 \\
363,689\end{array}$ \\
\hline
\end{tabular}

1 U. S. Statutes at Large, xiv, 515-517. This law carries out a provision in the act of July 17, 1862, directing that the surplus income from the navy pension fund "be applied to the making of further provision for the comfort of disabled officers, seamen and marines." These allowances are in addition to the pensions to which the persons concerned may be entitled under other laws.

$2 U$. S. Statutes at Large, $\mathrm{xv}, 170$.

3 From the reports of the Commissioner of Pensions. 
By an act of June 26, 1812, a privateer pension fund was established which continued in existence until $1837 .^{1}$ The fund consisted of two per cent of the net amount of the prize money accruing to privateers of the United States. Pensions were paid, under supervision of the Secretary of the Navy, to those who were wounded and disabled on board the private armed vessels of the United States in engagements with the enemy, and also to the widows and orphans of such as died by reason of their wounds. The fund was managed in much the same way as the navy pension fund, and at one time amounted to about $\$ 200,000 .^{2}$ The income of the fund was not sufficient to meet all claims upon it, and it gradually declined in amount. In May, 1837, the last stock owned by the fund was sold. At that time there were thirty-six pensioners on the fund, and the annual amount required to pay them was about $\$ 2,900 .^{3}$ The Secretary of the Navy recommended in 1838 that the nation assume the payment of the pensions which had been stopped. ${ }^{4}$ Congress by act of June 15 . 1844 , renewed the privateer pensions to begin with July $1,1837 .{ }^{5}$ They were thereafter included in the ordinary pension appropriations. The obsolete provisions for the establishment and administration of the privateer pension fund still remain on the statute books.

1 U. S. Statutes at Large, ii, 759.

2 American State Papers, Naval Affairs, i, 666-667.

${ }^{3}$ Report of the Secretary of the Navy for 1837. Senate Doc., 25th Cong., 2d Sess., 1837-1838, i, Doc. No. 1. 724.

4 Senate Doc., 25th Cong., 3d Sess., 1838-1839, i, Doc. No. 1, 597.

- $U$. S. Statutes at Large, v, 667. 


\section{CHAPTER V}

\section{War of 1812, Indian Wars, and Mexican War Pensions}

When the regular army and the navy were employed in the "old wars," which are the subject of this chapter, they enjoyed the benefit of pension provisions which have been described in the chapter just preceding. But the enlarging of the military forces of the United States in time of actual warfare caused the broadening and extension of the ordinary pension laws to meet the new conditions in each case and to provide pension benefits for volunteers and militia. After the lapse of many years, these "old wars" also gave rise to claims for service-pensions in accordance with the precedent which had been established in the case of the soldiers of the Revolution. The movement for such servicepensions invariably met with ultimate success, and the cost of pensions of this class was far larger than that of invalid-pensions for each of the wars under discussion.

\section{War of 1812 Pensions}

Various acts raising troops for the War of 1812 promised to the soldiers enlisting the benefit of the same invalid-pension provisions as had been made for the regular army by the act of 1802 . The total disability rate for private soldiers was five dollars a month and for commissioned officers not to exceed one-half of the monthly pay. After the war, in 1816, a full invalid-pension for a private soldier was increased to eight dollars a month, and there was also an increase in the pension rates applicable to the lower grades of commissioned officers. ${ }^{1}$ The same act extended the benefits of all pension provisions for the regular army to the officers and soldiers of militia while in the service of the United States. Half pay pensions for five years were also granted to widows and orphans of soldiers of the War of 1812. This half

${ }^{1}$ U. S. Statutes at Large, iii, 296-297. Act of April 24, 1816. 
pay was, in the case of the widow of a private soldier, regularly $\$ 48$ a year. ${ }^{1}$ When such half pay allowances expired, they were eventually renewed, and, before the Civil War, pensions had been granted for life to all surviving War of 1812 widows whose husbands had died as a result of wounds received, or of disability incurred, in service. Pension rates for disabilities incurred in the War of 1812 were made equal to Civil War rates by some of the earlier pension acts passed on behalf of the latter war.

Service-pensions on account of the War of 1812 were not granted until 1871 . With the lapse of time, the number of invalid-pensioners had become very small, and a long continued agitation for service-pensions finally met with success. In asking service-pensions, the survivors of the War of 1812 appealed to the Revolutionary service-pension act of 1832 as a precedent, and thus the predictions made by senators in the debate on that law were fulfilled.

The War of 1812 pension act which became law on February 14,1871 , was one of numerous bills on the subject proposed in Congress. One subject of controversy in the debates on the measure was the propriety of including in the law a so-called "pauper clause," requiring proof of indigence on the part of applicants for pensions. This would have been similar to the provision contained in the Revolutionary pension act of 1818. However, the majority gave approval to a simple service-pension act without property qualification. As usually happens with pension legislation, there was an underestimate of the number of claimants who would apply and of the amount of expenditure involved. In its final form the act of 1871 granted pensions to all surviving soldiers and sailors who had served sixty days in the War of 1812 and were honorably discharged, or who had received personal mention by Congress for specific services in the war. Applicants were required to have been loyal during the Civil War and to take an oath to support the Constitution. Pensions were also granted by this law to the surviving widows of those who had performed

1 Acts of April 16, 1816, and March 3, 1817, U. S. Statutes at Large, iii, $285,394$. 
the required service, provided that the widows had been married prior to the treaty of peace and had not remarried. The rate allowed to both soldiers and widows was eight dollars per month during life. ${ }^{1}$

At the time of the passage of the law of 1871 , there were few survivors of the War of 1812 on the pension rolls. The effect of this new service-pension measure was promptly felt. Within eight months of its passage, about 32,000 claims had been received and a new class of pensioners had been established. About 25,000 persons claimed as survivors and 7,000 as widows. ${ }^{2}$ The number of widows' applications was greatly limited by the restriction of the benefits of the act to widows who had been married prior to the treaty of peace and had not remarried. Statistical information with regard to the results of this act can be found in the table on page 113 .

Almost immediately after the passage of the act of 1871 , bills were put forward in Congress in the interest of greater liberality in pension legislation for the War of 1812. The removal of the restriction on widows' pensions was particularly advocated. By the later seventies the group of Washington claim attorneys became active in stimulating the demand for additional pension legislation, and a new War of 1812 pension law was one of the items included in their program. ${ }^{3}$ The desired end was finally attained in the act of March 9,1878, which received commanding majorities in both House and Senate. ${ }^{4}$ This measure opened the way to the pension, rolls to all who could establish even a slight connection with the War of 1812. Service for fourteen days or in any engagement, with honorable discharge, gave title to a pension of eight dollars per month during life. Record evidence of the service and honorable discharge were not required, but applicants might establish their claims by any other satisfactory

1 U. S. Statutes at Large, $\mathrm{xvi}, 411$.

2 Report of the Commissioner of Pensions for 1871.

3 George E. Lemon, long the leading Washington pension attorney, established his National Tribune in October, 1877. In its early numbers, this publication urged the enactment of additional War of 1812 pension legislation.

$4 U$. S. Statutes at Large, $\mathbf{x x}, 27$. 
testimony. The surviving widows of persons who had performed the required service were entitled to be pensioned at the same rate. In this law the restriction as to the date of the widow's marriage was removed, and pensions were provided for widows unborn when the war was fought. Congress accepted the argument made in the debates that "the affectionate ministrations of a devoted wife during the declining years of an infirm and too often destitute and suffering soldier should receive some recognition on the part of the government created and established by their [sic] valor and services in the field." However, the law provided that remarriage should terminate a widow's pension.

Besides shortening the necessary term of service to fourteen days, the act of 1878 abolished the requirement of loyalty during the Civil War. Provision was made for the restoration to the rolls of all War of 1812 pensioners whose pensions had been stopped because of disloyalty. In case pensioners thus stricken from the rolls had died without restoration, their widows were given the right to receive pensions under the new act.

By 1878 claims under the act of 1871 were nearly exhausted. In a little over seven months, the Commissioner of Pensions reported that about 25,000 claims had been presented under the new law. ${ }^{1}$ Aged survivors presented only about one-seventh of these claims on account of a war which had ended sixty-three years before. Such a condition of affairs was in marked contrast to that after the passage of the act of 1871 , when the great majority of claims was by survivors. The change was due to the removal of the restriction on the date of marriage of widows and also to the great mortality among the survivors, who had all reached a very advanced age.

There has been no further general pension legislation on account of the War of 1812, although the act of March 19, 1886, operated to increase the pensions of widows of that war to twelve dollars a month, and the act of September 8, 1916, provides that such widows shall receive twenty dollars per month when they

1 Report of the Commissioner of Pensions for 1878. 
have reacheci the age of seventy. The last surviving pensioned soldier of the War of 1812 was Hiram Cronk of Ava, Oneida County, N. Y. He died May 13, 1905, at the age of about 105 years. ${ }^{1}$ On June 30, 1916, more than a century after the close of the war, 115 widows remained on the pension roll. ${ }^{2}$

Exact information as to the cost of the invalid-pension legislation for the War of 1812 is not available. The service-pension laws of 1871 and 1878 have resulted in total expenditures of about $\$ 46,000,000$. The following table exhibits the detailed results of the operation of those laws:

1 Report of the Commissioner of Pensions for 1905, 37.

I Ibid., for 1916. 
War of 1812 Pensions Since $1871^{1}$

\begin{tabular}{|c|c|c|c|c|c|c|}
\hline \multirow{2}{*}{$\begin{array}{c}\text { Fiscal } \\
\text { Year }\end{array}$} & \multicolumn{3}{|c|}{ No. of Pensioners on Rolls } & \multicolumn{3}{|c|}{ Expenditures } \\
\hline & Survivors & Widows & Total & Sirvivors & Widows & Total \\
\hline 1871 & & & 727 & $\$ 2,555.05$ & $\$ 511.00$ & $\$ 3,066.05$ \\
\hline & 17,100 & 3,027 & 20,127 & $1,977,514.84$ & $335,993.63$ & $2,313,409.47$ \\
\hline 1873 & & 5,053 & 23,319 & $2,078,606.98$ & $689,303.59$ & $2,767,910.57$ \\
\hline 1874 & 17,620 & 5,312 & 22,932 & $1,588,832.95$ & $616,016.40$ & $2,204,849.35$ \\
\hline 1875 & 15,875 & 5,163 & 21,038 & $1,355,599.86$ & $533,000.21$ & $1,888.600 .07$ \\
\hline 1876 & 14,206 & 4,987 & 19,193 & $1,089,037.18$ & $445,772.95$ & $1,534,810.13$ \\
\hline 1877 & 12,802 & 4,609 & 17,411 & $934,657.82$ & 48.91 & 206.73 \\
\hline 1878 & 10,407 & 3,725 & 14,132 & $768,918.47$ & $294,572.05$ & $1,063,490.52$ \\
\hline 1879 & 11,621 & 21,194 & 32,815 & $1,014.525 .66$ & $2,192,699.54$ & $3,207,225.20$ \\
\hline 1880 & 10,138 & 24,750 & 34,888 & $790,710.39$ & $2,658,058.14$ & $3,448,768.53$ \\
\hline 1881 & 8,898 & 26,029 & 34,927 & $621,612.80$ & $2,381,800.95$ & $3,003,413.75$ \\
\hline 1882 & 7.134 & 24,661 & 31,795 & $478,274.85$ & $2,024,207.63$ & $2,502,482.48$ \\
\hline 1883 & 4,931 & 21,336 & 26,267 & $357,334.81$ & $1,882,542.41$ & $2,239,877.22$ \\
\hline 1884 & 3,898 & 19,512 & 23,410 & $278,888.85$ & $1,686,302.09$ & $1,965,190.94$ \\
\hline 1885 & 2,945 & 17,212 & 20,157 & $207,782.80$ & $1,518,202.39$ & 1,7 \\
\hline 1886 & 1,539 & 13,397 & 14,936 & 9.59 & 96.44 & 286.0 \\
\hline 1887 & 1,069 & 11,831 & 12,900 & $105,837.01$ & 2.36 & 19.37 \\
\hline 1888 & 806 & 10,787 & 11,593 & $73,659,48$ & 04.96 & 4.44 \\
\hline 1889 & 603 & 9,964 & 10,567 & 27 & 09 & 1, \\
\hline 1890 & 413 & 8,610 & 9,023 & $38,847.09$ & 1,2 &, 086.46 \\
\hline 1891 & 284 & 7,590 & 7,874 & $22,504.64$ & $1,040,284.41$ & $1,062,789.05$ \\
\hline & 165 & 6,651 & 6,816 & $11,908.93$ & 827 & 9.46 \\
\hline 1893 & 86 & 5,425 & 5,511 & $10,494.27$ & 721 & 73 \\
\hline & 45 & 4,447 & 4,492 & $5,312.20$ & 645 & 9.66 \\
\hline 1895 & 21 & 3,826 & 3,847 & $3,583.27$ & 541, & 06.75 \\
\hline & 14 & 3,287 & 3, & 27 & & \\
\hline 18 & 7 & 2,810 & 2,817 & $1,440.00$ & 388 & 38 \\
\hline & 3 & 2,407 & 2, & 6 & & \\
\hline 1899 & 1 & 1,998 & 1,9 & 193.33 & & 29 \\
\hline 1900 & 1 & 1,742 & 1,743 & & & \\
\hline 1901 & 1 & 1,527 & & 96.00 & & 21 \\
\hline & 1 & 1,317 & 1,3 & 109.03 & & \\
\hline 1903 & 1 & 1,115 & 1,1 & 342.93 & & \\
\hline 19 & 1 & 918 & 919 & 300.00 & & \\
\hline & 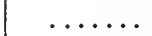 & 776 & $7 \%$ & 300.00 & & \\
\hline & & 660 & 660 & 4.80 & & \\
\hline & & 558 & 558 & $\ldots$. & $83,830.00$ & 83,83 \\
\hline & & 471 & 471 & & & $68,766.00$ \\
\hline 19 & $\cdots$ & 395 & 395 & $\ldots$. & 62,7 & $62,731.60$ \\
\hline 19 & & 338 & 33 & & 51.27 & $51,279.90$ \\
\hline & & 279 & 279 & .. & $44,347.45$ & $44,347.45$ \\
\hline & & 238 & 238 & & 37,81 & $37,819.20$ \\
\hline & . & 190 & 19 & $\cdots$ & & $32,171.07$ \\
\hline & & 170 & 17 & & 2.40 & $27,532.40$ \\
\hline 1915 & & 13 & & & $22,348.90$ & $22,348.90$ \\
\hline 1916 & … & 115 & 115 & & $18,848.00$ & 18.848 .00 \\
\hline & ath & & & 0197 & & \\
\hline
\end{tabular}

${ }^{1}$ Compiled from the reports of the Commissioner of Pensions. 


\section{Indian Wars Pensions}

From time to time in the history of the United States, the government has been engaged in armed conflicts with hostile Indian tribes. Many of these disturbances have been of sufficient importance to be termed wars. It has been the uniform custom of Congress to extend the benefits of existing pension laws to soldiers disabled in such campaigns and also to the widows and orphans of the slain. An early example of such provision for those engaged in fighting hostile Indians was the act of 1812 for the relief of the officers and soldiers who served in General Harrison's campaign on the Wabash - the victors of the battle of Tippecanoe. From that time down to the Civil War the benefits of the invalid-pension laws were frequently extended to those engaged in putting down Indian insurrections in Florida, Illinois, Wisconsin and other states. At the outbreak of the Civil War, the survivors and widows of soldiers of the various Indian Wars stood on the same footing as to pensions as those of the War of 1812. Since the Civil War the general-law pension system, inaugurated by the act of July 14,1862, has embraced within its benefits soldiers disabled in wars with Indian tribes and the dependent relatives of those who lost their lives as the consequence of such service.

Service-pensions were not granted on account of the Indian wars until the passage of the act of July $27,1892 .^{1}$ This measure was for the benefit of those "who served for thirty days in the Black Hawk War, the Creek War, the Cherokee disturbances, or the Florida War with the Seminole Indians" between 1832 and 1842, and were honorably discharged. The act included also such other survivors as had been personally named in any resolution of Congress for any specific service in the above Indian Wars, even though their term of service had been less than thirty days. Pensions were also granted to the surviving widows of persons who would have been entitled under the act, provided such widows had not remarried. The rate of pension for survivors and widows was eight dollars per month during life. Service and honorable discharge might be proved by any sat-

1 U. S. Statutes at Large, xxvii, 281. 
isfactory evidence, and loyalty during the Civil War was not required.

An act of June 27, 1902, extended the benefits of the above law to the surviving officers and enlisted men who served thirty days or more under the United States military, state, territorial, or provincial authorities in a considerable number of Indian wars fought between 1817 and $1858 .^{1}$ The act also included the widows of officers and men who had performed the required service in these wars, provided the widows had not remarried. The provisions of the act of 1892 were also extended by act of May 30.1908 , to the Texas volunteers who fought in the border disturbances between 1855 and 1860 .

The service-pensions of Indian Wars widows were increased to twelve dollars a month by act of April 19, 1908, and the pensions of survivors were increased to twenty dollars a month by act of February 9, 1913. An act of March 4, 1917, pensioned at the above rates certain survivors of various campaigns against Indians from 1859 to 1891 , and their widows.

Indian Wars Pensions Since $1893^{2}$

\begin{tabular}{|c|c|c|c|c|c|c|}
\hline \multirow{2}{*}{$\begin{array}{l}\text { Fiscal } \\
\text { Year }\end{array}$} & \multicolumn{3}{|c|}{ No. of Pensioners on Rolls } & \multicolumn{3}{|c|}{ Expenditures } \\
\hline & Survivors & Widows & Total & Survivors & Widows & Total \\
\hline 1893 & 2,544 & 1,338 & 3,882 & $\$ 158,076.26$ & $\$ 66,434.05$ & $\$ 224,510.31$ \\
\hline 1894 & 3,104 & 3,284 & 6,388 & $377,883.57$ & $456,652.25$ & $834,535.82$ \\
\hline 1895 & 3,012 & 3,911 & 6,923 & $308,365.24$ & $469,161.39$ & $777,526.63$ \\
\hline 1896 & 2,718 & 4,237 & 6,955 & $268,778.30$ & $468,694.44$ & $737,472.74$ \\
\hline 1897 & 2,373 & 4,288 & 6,661 & $227,580.41$ & $442,082.76$ & $669,663.17$ \\
\hline 1898 & 2,019 & 4,067 & 6,086 & $189,981.39$ & $418,997.35$ & $608,978.74$ \\
\hline 1899 & 1,656 & 3,899 & 5,555 & $165,327.01$ & $403,871,74$ & $569,198.75$ \\
\hline 1900 & 1,370 & 3,739 & 5,109 & $138,142.82$ & $379,035.07$ & $517,177.89$ \\
\hline 1901 & 1,086 & 3,479 & 4,565 & $111,973.91$ & $351,016.59$ & $462,990.50$ \\
\hline 1902 & 903 & 3,320 & 4,223 & $87,968.89$ & $324,183.09$ & $412,151.98$ \\
\hline 1903 & 1,565 & 3,169 & 4,734 & $111,765.28$ & $308,442.74$ & $420,208.02$ \\
\hline 1904 & 2,367 & 3,519 & 5,886 & $349,549.35$ & $396,933.03$ & $746,482.38$ \\
\hline 1905 & 2,269 & 3,461 & 5,730 & $270,737.93$ & $385,633.67$ & $656,371.60$ \\
\hline 1906 & 2,173 & 3,367 & 5,540 & $251,664.84$ & $371,210.01$ & $622,874.85$ \\
\hline 1907 & 2,007 & 3,201 & 5,208 & $220,467.88$ & $341,775.94$ & $562,243.82$ \\
\hline 1908 & 1,820 & 3,018 & 4,838 & $205,289.63$ & $328,034.20$ & $533,323.83$ \\
\hline 1909 & 1,744 & 2,881 & 4,625 & $198,335.84$ & $441,562.60$ & $639,898.44$ \\
\hline 1910 & 1,560 & 2,822 & 4,382 & $184,294.60$ & $437,214.93$ & $621,509.53$ \\
\hline 1911 & 1,387 & 2,629 & 4,016 & $168,688.24$ & $406,398.28$ & $575,086.52$ \\
\hline 1912 & 1.210 & 2,439 & 3,649 & $148,853.04$ & $372,550.95$ & $521,403.99$ \\
\hline 1913 & 1,066 & 2,330 & 3,396 & $176,292.72$ & $351,371.38$ & $527,664.10$ \\
\hline 1914 & 915 & 2,182 & 3,097 & $225,664.88$ & $334,582.52$ & $560,247.40$ \\
\hline 1915 & 786 & 2,046 & 2,832 & $199,772.96$ & $313,933.22$ & 513.706 .18 \\
\hline 1916 & 676 & 1,902 & 2,578 & $173,415.46$ & $301,656.48$ & $475,071.94$ \\
\hline \multicolumn{4}{|c|}{ Total. } & $\$ 4,918,870.45$ & $\$ 8,871,428.68$ & $\$ 13,790,299.13$ \\
\hline
\end{tabular}

1 U. S. Statutes at Large, xxxii, 399-400.

2 Compiled from the reports of the Commissioner of Pensions. 


\section{Mexican War Pensions}

When war broke out in 1846 between Mexico and the United States, an act of May 13, 1846, authorized the President to raise volunteers for the prosecution of the war. ${ }^{1}$ A section of this act promised to volunteers who should be wounded, or otherwise disabled in the service, benefit of the same pension provisions as were in force for regular troops. Between 1848 and 1850, several laws were passed granting five years' half pay to the widows and orphans of those who had died, or should die, as the result of wounds received or disease contracted in service during the war. In 1858 the half pay of widows was extended for life and that of orphans until they reached the age of sixteen years. ${ }^{2}$ At the time of the Civii War, invalid-pensions were granted for service in the Mexican War on the same basis as for service in the War of 1812 and Indian wars. The earlier Civil War pension laws increased the rates for all the "old wars" to a level with those paid on account of the Civil War. ${ }^{3}$

Soon after the survivors of the War of 1812 were granted service-pensions in 1871 , a movement was started to secure a similar law applying to the Mexican War. The question was long before Congress, and bills on the subject several times passed one house or the other. Especial interest was attached to the Mexican War pension bill of 1884 which passed the House of Representatives. In the Senate, that bill was burdened with amendments largely extending the Civil War pension system. In fact the amendments were far more important than the original bill. As a consequence, the bill which passed the Senate was not acceptable to the House, and, because of the failure of the two bodies to reach an agreement, there was no legislation on the subject at that session.

The advocates of service-pensions on account of the Mexican

1 U. S. Statutes at Large, ix, 9.

2 Ibid., xi, 309.

3 Section 3 of the act of July 25, 1866, Section 13 of the act of July 27, 1868, and Section 18 of the act of March 3,1873, U. S. Statutes at Large, xiv, 230; $\mathrm{xv}, 237$; $\mathrm{xvii}, 572$. 
War finally achieved success in the passage of the act of January 29, 1887. This law applied to persons "who being duly enlisted, actually served sixty days with the army or navy of the United States in Mexico, or on the coasts or frontier thereof, or en route thereto, in the war with that nation, or were actually engaged in a battle in said war, and were honorably discharged, and to such other officers and soldiers and sailors as may have been personally named in any resolution of Congress for any specific services in said war, and the surviving widows of such officers and enlisted men." Pensions at the rate of eight dollars per month during life were granted to the above described persons, provided they were either sixty-two years of age, or subject to a disability or dependency equivalent to some cause recognized by the pension laws of the United States as a sufficient reason for the allowance of a pension. No pension could be obtained by reason of a disability incurred by the applicant while voluntarily engaged in opposing the United States government during the Civil War. Disloyalty during the Civil War was not a bar to a pension, but the act did not include within its benefits any person while under the political disabilities imposed by the Fourteenth Amendment to the Constitution. The act did not apply to those already pensioned at the rate of eight dollars per month or more, and, as regards those receiving less than eight dollars per month, it authorized only the payment of the difference between the existing pension and eight dollars per month. As usual in such legislation, widows who had remarried were not eligible to receive pensions.

The Mexican War pension bill of 1887 came to President Cleveland for approval shortly before he received the Dependent Pension Bill for the benefit of Civil War veterans. Both measures granted pensions for service, provided applicants, qualified as to service, also suffered from disabilities in a pensionable degree. $^{2}$ The President signed the former and vetoed the latter.

\footnotetext{
1 U. S. Statutes at Large, xxiv, 371.

2 It was not required, however, that such disabilities be traced to an origin in military service.
} 
In thus acting, he was charged with inconsistency. However, a substantial reason for discrimination was the fact that the Mexican War veterans were much more advanced in age than were those of the Civil War.

In January, 1893, a law was passed authorizing the Secretary of the Interior to increase to twelve dollars per month the allowance of such Mexican War survivors then on the rolls as were wholly disabled for manual labor and in such destitute circun:stances that eight dollars per month was insufficient to provide them with the necessaries of life. The increase granted by the act of 1893 was limited to pensioners then on the rolls. In 1900 this limitation was removed for the benefit of pensioners, otherwise qualified, who had been placed on the rolls after 1893 . Finally, an act of March 3, 1903, increased the pension rate for all survivors of the Mexican War, entitled to be pensioned under the act of 1887 and supplementary legislation, to twelve dollars per month, irrespective of the conditions contained in the acts of 1893 and 1900. The pensions of Mexican War widows were also increased to twelve dollars per month by the act of Aprii 19, 1908.

Survivors of the War with Mexico were granted age-andservice pensions by the act of February 6, 1907.1 The length of service required was sixty days with an honorable discharge. At sixty-two years of age the rate was twelve dollars per month; at seventy years, fifteen dollars per month; at seventy-five years, twenty dollars per month. Pensions were to commence from the date of filing the application.

A paragraph in the Civil War pension act of May 11, 1912, further increased the pensions of Mexican War veterans by providing that "any person who has served sixty days or more in the military or naval service of the United States in the War with Mexico and has been honorably discharged therefrom, shall, upon making like proof of such service, be entitled to receive a pension of thirty dollars per month." ${ }^{2}$ Likewise, under the pro-

${ }^{1}$ U. S. Statutes at Large, xxxiv, 879.

2 Ibid., xxxvii, 112. 
visions of the act of September 8, 1916, the pensions of War with Mexico widows are increased to twenty dollars per month when they reach the age of seventy years.

The War with Mexico service-pensions have cost in all over fifty million dollars. On June 30, 1916, there were 513 Mexican War survivors on the pension roll and 3,785 widows. ${ }^{1}$ A tabular statement of the operation of War with Mexico pension laws since 1887 follows:

Mexican War Pensions Since 1887

\begin{tabular}{|c|c|c|c|c|c|c|}
\hline \multirow{2}{*}{$\begin{array}{l}\text { Fiscal } \\
\text { Year }\end{array}$} & \multicolumn{3}{|c|}{ No. of Pensioners on Rolls } & \multicolumn{3}{|c|}{ Expenditures } \\
\hline & Survivors & Widows & Total & Survivors & Widows & Total \\
\hline 1887 & 7,503 & 895 & 8,398 & $\$ 53,148.68$ & $\$ 2,548.08$ & $\$ 55,606.76$ \\
\hline 1888 & & 5.104 & 21,164 & 56.07 & $583,056.28$ & 12.35 \\
\hline 1889 & 12 & 6,206 & 23,271 & $1,796,899.30$ & $693,572.45$ & $2,490,471.75$ \\
\hline 1890 & 8 & 6764 & 23,922 & $1,728,027.54$ & $695,054.90$ & $2,423,082.44$ \\
\hline 1891 & & 6,976 & 23,355 & $1,622,114.75$ & $695,314.52$ & $2,317,429.27$ \\
\hline 1892 & 15,215 & & 22,497 & $1,425,258.18$ & $686,733.57$ & $2,111,991.75$ \\
\hline 1893 & 19 & & 21,518 & $1,396,392.38$ & $736,173.41$ & 665.79 \\
\hline 1894 & & & 21,147 & $1,388,707.07$ & $803,345.91$ & $2,192,052.98$ \\
\hline 1895 & & & 20, & 1,4 & .96 & 23.82 \\
\hline 1896 & & & 19,817 & & $814,096.14$ & 82.09 \\
\hline 1897 & & 2 & 180 & 1,2 & & 2.09 \\
\hline 1898 & & & & & & 68.89 \\
\hline 1899 & 4 & & 17, & & .58 & 52.21 \\
\hline 1900 & & & 3 & 1,01 & & 2.05 \\
\hline 1901 & 7 & 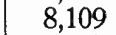 & 77 & .18 & .27 & 2.45 \\
\hline 1902 & & & 15 & & 75 & 3.88 \\
\hline 1903 & 5 , & 0 & 13 & 9.35 & .99 & 72.34 \\
\hline 19 & & & & & & 820.44 \\
\hline 1905 & 4,540 & & 12 & & & 18.52 \\
\hline 19 & & & 11 & & & 96.36 \\
\hline 1907 & & & 10 & & & 8.34 \\
\hline 19 & & & & & & 45.53 \\
\hline 1909 & & & 2 & & 4.99 & 04.97 \\
\hline 19 & 2,0 & & 8,401 & & 942 , & 84.65 \\
\hline 19 & 1,6 & & 7,6 & 22 & 86.89 & $1,322,918.11$ \\
\hline & & & & & & 185.61 \\
\hline 191 & 1,142 & & & 41 & 3.55 & $1,184,699.90$ \\
\hline 19 & & & & & 95 & 29.74 \\
\hline & & & & & & 6.60 \\
\hline 1916 & 513 & 3,785 & 4,298 & $213,118.76$ & $590,161.78$ & $803,280.54$ \\
\hline \multicolumn{4}{|c|}{ Tot } & 0,0 & 23 & $\angle Z$ \\
\hline
\end{tabular}

I Report of the Commissioner of Pensions for 1916. 
$\left.\operatorname{lol}_{-1}\right)_{-1}^{1}=1$ 


\section{PART II}

PENSIONS BASED ON MILITARY SERVICE AFTER MARCH 4, 1861 


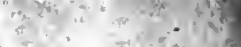




\section{CHAPTER I}

\section{Civil War Pensions-The General Law System}

The American Civil War has become a rather remote event in history. When in 1915 we observed the semi-centennial of Lee's surrender to Grant, the world was already in the agonies of a gigantic struggle between nations that has relegated our civil conflict to the list of lesser wars of the past. Men now beyond the middle years of life were unborn when the Union and Confederate armies disbanded and returned to their homes. After half a century, each year sees the ranks of the aged veterans of those armies relentlessly depleted by death. But this increasing distance from the period of civil warfare and this passing of the veteran armies have not yet been accompanied by much lightening of the burden of pension expenditures. In fact, until recently it has been true that the farther we have been removed in years from the Civil War the greater has become the pension outlay consequent upon it.

In 1870 the expenditure of the United States government for military pensions (exclusive of administrative expenses) was $\$ 29,000,000$; in 1880 it was $\$ 57,000,000$; in 1890 it had increased to $\$ 106,000,000$; in 1900 the outlay was $\$ 138,500,000$; by 1910 it had risen to $\$ 160,000,000$; a maximum sum of $\$ 174,000,000$ was reached in 1913 ; by 1916 there was a decline to $\$ 159,000,000{ }^{1}$ To be sure, these amounts included a few millions yearly for minor wars, but the proportion of the expenditure devoted to Civil War pensions was so large as to make the sum used in pensions for the "old wars" almost negligible. Contrasted with these imposing anmual disbursements, how meager and insignificant seems the payment of only about $\$ 90,000,000$ in pensions for the whole period from the founding of the federal government down to the opening of the Civil War! ${ }^{2}$ Since 1861 expenditures for pensions have piled up until they amount to a total

\footnotetext{
1 Report of the Commissioner of Pensions for 1916, 20.

2 Prior to the Civil War, $65,000,000$ acres of bounty land had also been granted to former soldiers as a reward for their services.
} 
in excess of five billions of dollars. New and more liberal grants have constantly served to offset the inroads of death among the Union veterans and their widows and dependent relatives.

The hostilities of the Civil War caused no pensioners to be placed upon the rolls until after the close of the fiscal year 1861 on June 30. There were then some 10,700 persons on the rolls, of whom 63 were soldiers of the Revolution-which ended seventy-eight years before-and 2,728 were the widows of such soldiers. The actual outlay for pensions in 1861 was $\$ 1,072,000$, and the aggregate annual value of the roll was $\$ 958,000 .{ }^{1}$ Under the laws then in force, the number of beneficiaries was decreasing at the rate of five or six hundred each year, and with continued peace the pension system would soon have been of small importance.

The outbreak of war radically changed the situation and ushered in a new era of pension expenditures. Bull Run and other battles caused the rapid filing of claims at the Pension Bureau by disabled soldiers and by the widows and orphans of the slain. At first there were no laws adequate to the emergency. The earliest pension provision for the Civil War was contained in the act of July 22, 1861, passed at an extraordinary session of Congress to authorize the President to accept the services of not exceeding five hundred thousand volunteers. ${ }^{2}$ A section of this law provided that all-volunteers under its provisions, who might be wounded or otherwise disabled in the service, should be entitled to the benefits conferred on persons disabled in the regular army. The widows or legal heirs of such as should die in the service were promised the sum of one hundred dollars, in addition to all arrears of pay and allowances. Thus, at the very outset of the war, invalid-pensions were offered as an inducement to promote voluntary enlistments.

The pension provision in the act of July 22, 1861, did not, however, apply to the soldiers called into service by President Lincoln's proclamations of April 15 and May 3. These were the

${ }^{1}$ Statistics from the Report of the Commissioner of Pensions for 1861.

$2 U$. S. Statutes at Large, xii, 270. 
men who fought at Bull Run and in minor engagements. When claims were filed in their behalf, old laws were deemed to warrant allowances in some cases. But the uncertainties and discrepancies of existing provisions led the Commissioner of Pensions to ask for the prompt enactment of explicit and detailed legislation by Congress. ${ }^{1}$ With practically no opposition in either house, Congress passed a new and far reaching pension law which was approved by the President on July $14,1862 .^{2}$ This became the fundamental law for all pension claims arising out of disabilities or death due to military service after March 4, 1861. It embraced within its provisions army and navy alike, including regulars, volunteers, militia, and the marine corps. Its application extended forward indefinitely, including not only the Civil War but all future wars, or military or naval enterprises, in which the United States might be engaged.

In passing the act of 1862, Congress founded what has been called in the Bureau of Pensions the "general law pension system." This was the only system of pension laws in force and applying to the Civil War until 1890. It provides pensions for soldiers who have incurred permanent bodily injury or disability in military service after March 4, $1861 .^{3}$ The claimant must show that his disabiiity was incurred as the direct consequence of the performance of his military duty. This system also provides for the widows, children and other dependent relatives of soldiers who died in actual military service, or, after the close of hostilities, from causes which can be directly traced to injuries received or discase contractcd while in military service.

In contrast with the general law system is another system of pensions which was inaugurated in 1890 for the benefit solely of the veterans of the Civil War and their dependent relatives. This latter system began with the act of June 27,1890 , and has been

${ }^{1}$ For further details of the situation, see Glasson, History of Military Pension Legislation in the United States, 72-73.

$2 U$. S. Statutes at Large xii, 566-569.

3 The general law pension system applied, therefore, to service in the regular army and navy and to the War with Spain. It was in full force when the United States entered the European War. 
made more and more liberal by succeeding laws. It provides pensions based on proof of the fact of military service in the Civil War for a period of ninety day's or more and honorable discharge, coupled with the existence of a bodily disability not shown to be of service origin, or with the attainment of a certain age. Under this system pensions are also given to the widows and children of Civil War soldiers aithout regard to the cause of the soldier's death. The development and details of the system under the act of 1890 and succeeding laws will be the subject of a later chapter. It is a service-pension system with limitations.

In the present chapter, an account will be given of the general law pension system developed from the act of July 14, 1862. This is an invalid-or disability-pension system, with a pension provided for the widow or dependent relatives of a soldier when his death was the immediate or ultimate result of his performance of military duty.

For disabilities caused by wounds received or disease contracted while in the service of the United States and in the line of duty, the act of 1862 granted pensions graded according to rank from thirty dollars to eight dollars per month in cases of total disability. The former amount was allowed to a lieutenant colonel or officer of a higher grade in the army or marine corps, and to a captain, commander, or officer of equal rank in the navy. Proportionate pensions were to be given in each rank for partial disability. Invalid-pensions were to commence from the date of discharge in all cases in which the application should be filed within one year after that date. Otherwise the pension was to be paid, if allowed, from the date of filing the application. In all cases invalid-pensions were to continue during the existence of the disability.

The act of 1862 established a new standard of comprehensiveness and liberality in pension provisions for widows, children, and dependent relatives. To the widow, or if there were no widow, to the child or children under sixteen years of age. of any person dying, after March 4, 1861, by reason of any wound received, or disease contracted, while in the service of 
the United States and in the line of duty, the law granted the same pension as would have been allowed to the husband or father for total disability. Such pensions were payable from the death of the husband or father, to the widow during her widowhood, or to the child or children until they severally attained the age of sixteen years. If a deceased soldier left no widow or legitimate child but a dependent mother, the mother was entitled to receive the pension which might have been allowed to a widow or child. A remarriage of widow or mother terminated the pension, nor could any mother receive at the same time more than one pension under the provisions of the act. Neither widow, child, nor mother surviving the deceased soldier, the pension might be given to an orphan sister or sisters, under sixteen years of age, who were wholly or in part dependent upon him for support. The pension was to be paid to such sister or sisters until they severally attained the age of sixteen years, but such orphans were in no case to receive more than one pension under the law at the same time. Payment of pensions to any disloyal relatives or heirs of a deceased soldier was specifically forbidden, and the right to such payment was transferred to the loyal heirs, if there were any. ${ }^{1}$

Many administrative matters were also dealt with by the act of 1862 , including provisions regulating attorneys' fees, impos-

\footnotetext{
${ }^{1}$ Since 1862 it has been the general rule that those who were not loyal during the Civil War are ineligible to receive the benefits of the national pension laws. An order of the Pension Bureau issued before the semiannual payment of September 4,1861, required the oath of allegiance to be taken by pensioners before receiving their stipends. The pension agencies in the disloyal states were suspended, as were also the pensions of disaffected persons in loyal states. By the end of the war the names of all the pensioners in the eleven Confederate states had been stricken from the rolls. After the close of hostilities, such as were able to prove their continued loyalty in act and sympathy throughout the war were restored to the pension list, and also received the arrears which had accrued since the last payment prior to the war. In later years exceptions to this requirement of loyalty have been made in the service-pension acts passed on behalf of the soldiers of the "old wars," in the application of the general pension law to the War with Spain, and in certain other cases. The loyalty requirement was finally repealed entirely by approval of the act of August 29, 1916. (The question of loyalty is discussed in the reports of the Commissioner of Pensions for $1861,1862,1865,1866$ and later years. See also in U. S. Statutes at Large, acts of March 3, 1877, March 9, 1878, January 29, 1887, July 27, 1892, August 1, 1892, April 18, 1900, and joint resolution of July 1, 1902.)
} 
ing penalties for frauds by agents and attorneys, regulating the appointment and fees of examining surgeons, and authorizing the Secretary of the Interior to appoint a special agent to assist in the prosecution and detection of pension frauds. The last section of the act repealed all previous pension enactments inconsistent with its provisions.

In many ways the pension law of 1862 was epoch making. Mothers and orphan sisters had never before been provided for in our national legislation. ${ }^{1}$ The pensions allowed to other classes, particularly to widows and orphans and to disabled seamen, were largely increased. Greater uniformity in the rates of army and navy pensions was also secured. As a whole the act explicitly committed the federal government, early in the war, to a pledge of pensions to all disabled Union soldiers and also to a similar provision for the dependent relatives of those who should lose their lives in the service. In fact, the measure did even more than this. It was not carefully limited to the Civil War, but it inaugurated a body of pension legislation applicable, without further action by Congress, to service in the regular army, the War with Spain, the fighting in the Philippines, and to any future war in which the United States might be engaged. Since 1862 every soldier or sailor of the United States has from the date of enlistment enjoyed the benefits and protection of the comprehensive provisions of the general pension law. But subsequent enactments have made the law far more liberal than it was during and immediately after the Civil War.

The passage of the pension law of 1862 through Congress was rather uneventful. ${ }^{2}$ Public attention was devoted to other more exciting events of the period. However, the Commissioner of Pensions speaks of "apprehensions in some quarters of an ex-

${ }^{1}$ See the Rhode Island colonial law of 1718 , pages 16 and 17.

2 In the House debate Mr. Holman of Indiana opposéd any distinction in pension rates between officers and private soldiers. He unsuccessfully advocated a uniform total disability rate of thirteen dollars a month for all ranks. Although his remarks savored a little of buncombe, he did real service in insisting on a provision limiting the fees of claim agents. Congressional Globe, 37th Cong., 2d Sess., 1861-1862, Part 3, 2100-2106; Part 4, 3213-3214. 
travagant, if not insupportable, annual burden resulting from the law." He thought such apprehensions unwarranted, and in November, 1862, predicted that the total annual sum required to carry out the law would in no year exceed $\$ 7,000,000 .^{1}$ In his later report for 1864, Commissioner Barrett pointed out that the unexpected duration of the war had rendered the above estimate entirely inadequate. By June 30,1864 , about 47,000 pensions had been granted under the act of $1862,21,000$ to invalids, and 26,000 to widows, orphans, and dependent relatives. The federal pension list at this time contained 51,135 names, a much greater number than ever before. ${ }^{2}$

\section{Development of the Invalid-Pension System}

Though the national pension system seemed liberal to its administrators in 1864, it was just at the beginning of a long period of expansion. Before the war was over, the first step was taken in the establishment of increased statutory rates for certain permanent specific disabilities of a severe character. A shocking injury like the loss of the sight of both eyes or the loss of both hands aroused unusual sympathy for the victim and sense of national obligation to him. It was felt that the total disability rate of eight dollars a month was entirely inadequate in such a case. So an act became law on July 4, 1864, which granted a monthly pension of $\$ 25$ for the loss of both hands or the loss of the sight of both eyes, and of $\$ 20$ for the loss of both feet. $^{3}$ The act of March 3, 1865, also allowed the $\$ 20$ a month rate for the loss of one hand and one foot. ${ }^{4}$ Fourteen additional permanent specific disabilities were provided for by the act of June 6,1866 , at rates of $\$ 25, \$ 20$ and $\$ 15$ a month. ${ }^{5}$ An increase of these three special grades of statutory rates to $\$ 31.25, \$ 24$,

${ }^{1}$ Report of Commissioner of Pensions, 1862. Message and Documents, 1862-1863, Part 2, 580-581.

2 Report of Commissioner of Pensions, 1864.

${ }^{3} U$. S. Statutes at Large, xiii ,387-389. The act of 1864 also contained important administrative provisions.

4 Ibid., xiii, 499-500.

5 Ibid., xiv, 56. 
and $\$ 18$ a month respectively was made by the act of June 8 , 1872, (the increase dating from June 4,1872 ). ${ }^{1}$ The Commissioner of Pensions estimated that 16,000 pensions would be affected by the increase act of 1872 , and up to November 1 of that year 13,500 cases had been acted upon. There were on the pension roll on June $30,1872,232,229$ pensioners of all classes of whom 96,854 were army and navy invalids. ${ }^{2}$

It is easy to understand the causes which led to the enactment of statutory rates for certain permanent disabilities higher than the normal rate for total disability (which was in 1862 understood to be disability for the performance of manual labor). But the practice opened the way for great confusion-and even absurdity -in the system of invalid-pension rating. The act of 1862 remained in force with its total disability rate ranging from $\$ 30$ a month for a lieutenant colonel or officer of higher grade down to eight dollars a month for a private soldier. So long as the fixed statutory rates were limited to such very specific injuries as the loss of an arm or leg, or the loss of sight, there was no great difficulty in treating them as exceptions to the normal total disability rate under the general law. However, there was soon pressure for high statutory rates for disabilities of a severe character not so self-evident or easily ascertainable. The act of June 6,1866 , previously referred to, introduced statutory rates of $\$ 25$ a month for disability of such a character as to require the regular aid and attendance of another person, $\$ 20$ a month for incapacity to perform manual labor, and $\$ 15$ a month for disability equizalent to the loss of a hand or foot. By the act of June 8,1872 , these three rates were increased to $\$ 31.25, \$ 24$, and $\$ 18$ respectively. Certainly there was incongruity between the law which provided that a private soldier should receive $\$ 8$ a month for total disability to perform manual labor and the other provision of the law which said that he should receive $\$ 24$ a month for incapacity to perform any manual

$1 U$. S. Statutes at Large, xvii, 335.

${ }^{2}$ Report of the Commissioner of Pensions for 1872, House Ex. Doc., 3d Sess., 42d Cong., Doc. 1, Part 5, pages 321 and 329. 
labor. How the Pension Bureau dealt with the difficulty at the time is shown by the following extract from the report of Commissioner Baker for 1874 :

The difficulties of the subject [equitably rating disabilities under existing laws] are increased by the fact that under existing law two different degrees of disability, for which rates of pension differing widely are provided, may be confounded. 'The act of July 14, 1862, provided a pensicn of $\$ 8$ per month in the case of a private soldier for a tota! disability for the performance of manual labor. For a disability incapacitating for the performance of any manual labor, the act of June 6,1866 , provided a pension of $\$ 20$ per month, which was increased to $\$ 24$ per month by the act of June 8,1872. The words "total disability" which occur in the act of July 14,1862, have been construed by this office to mean a total disability for the performance of manual labor requiring severe and continuous exertion. The words "any manual labor" occurring in the act of June 6, 1866 , and the act of June 8,1872 , have been construed to include also the lighter kinds of labor which require education and skill. It is believed that the construction given by this Office to these acts is in accordance with the intention of their framers; but, as it is difficult to draw a line of distinction between the two kinds of labor, there is to some extent a conflict between the acts referred to, which renders their execution difficult, and the decisions of the Office thereunder unsatisfactory to claimants. If the law could be so amended as to provide more definite standards for the comparison of degrees of disability, the Bureau would be relieved from its greatest source of embarrassment. This Office is not at present prepared to suggest a remedy for the manifest difficulty; but in justice to itself the embarrassment arising from this source ought to be pointed out. ${ }^{1}$

Later legislation had the effect of putting the rates fixed for specific disabilities even more out of harmony with the "total disability" rate of the act of 1862 . A long series of laws, the

${ }^{1}$ Report of the Commissioner of Pensions for 1874. House Ex. Doc., 2d Sess., 43d Cong., Doc. 1, Part 5, 661. 
last of which was passed on April 8,1904, greatly increased the statutory rates for the various grades of permanent specific disabilities. (See table on page 133.) Some new grades were added. At present the maximum invalid-pension of $\$ 100$ a month is paid for the loss of both hands, the loss of both feer, the loss of the sight of both eyes, and the loss of the sight of one eye, the sight of the other having been lost before enlistment. Other illustrative rates are $\$ 72$ a month for such a degree of helplessness as to require the regular aid and attendance of another person, $\$ 55$ a month for loss of an arm at the shoulder joint, $\$ 40$ a month for loss of a hand or a foot, $\$ 46$ a month for total disability in an arm or leg, $\$ 40$ a month for total deafness, $\$ 30$ a month for incapacity to perform manual labor, and $\$ 24$ a month for disability equivalent to the loss of a hand or a foot.

Another far reaching change in the method of rating disabiiities under the general law was introduced by a provision in the so-called "Consolidation Act" of March 3, 1873. ${ }^{1}$ In 1871 Commissioner of Pensions Baker recommended that all the needful provisions of past pension legislation, cleared of what was doubtful, contrary or cumbersome, be codified into one act. $\mathrm{He}$ thought that no additional or more liberal legislation was needed. Later, in his report for 1872 , he recommended the establishment of a rate between $\$ 8$ and $\$ 18 .{ }^{2}$

In compliance with Mr. Baker's recommendation, a bill was introduced (April 15, 1872) in the House of Representatives at the second session of the Forty-second Congress "to revise, consolidate, and amend the laws relating to pensions." It was represented as principally a codification of the pension laws with a few amendments. ${ }^{3}$ It passed the House but was not taken up by the Senate until the next session. On February 12, 1873, Senator Pratt of Indiana, in charge of the bill, explained its provisions to the Senate. ${ }^{4}$ He said that it changed the rates of pensions in a few particulars, but he did not think it increased the

1 U. S. Statutes at Large, xviii, 566.

2 Report of the Commissioner of Pensions for 1871 and 1872.

${ }^{3}$ Congressional Globe, 2d Sess., 42d Cong. (1871-1872), Part 3, 2442, 3296.

4 Ibid., 3d Sess., 42d Cong. (1872-1873), Part 2, 1283. 
THE GENERAL LAW SYSTEM

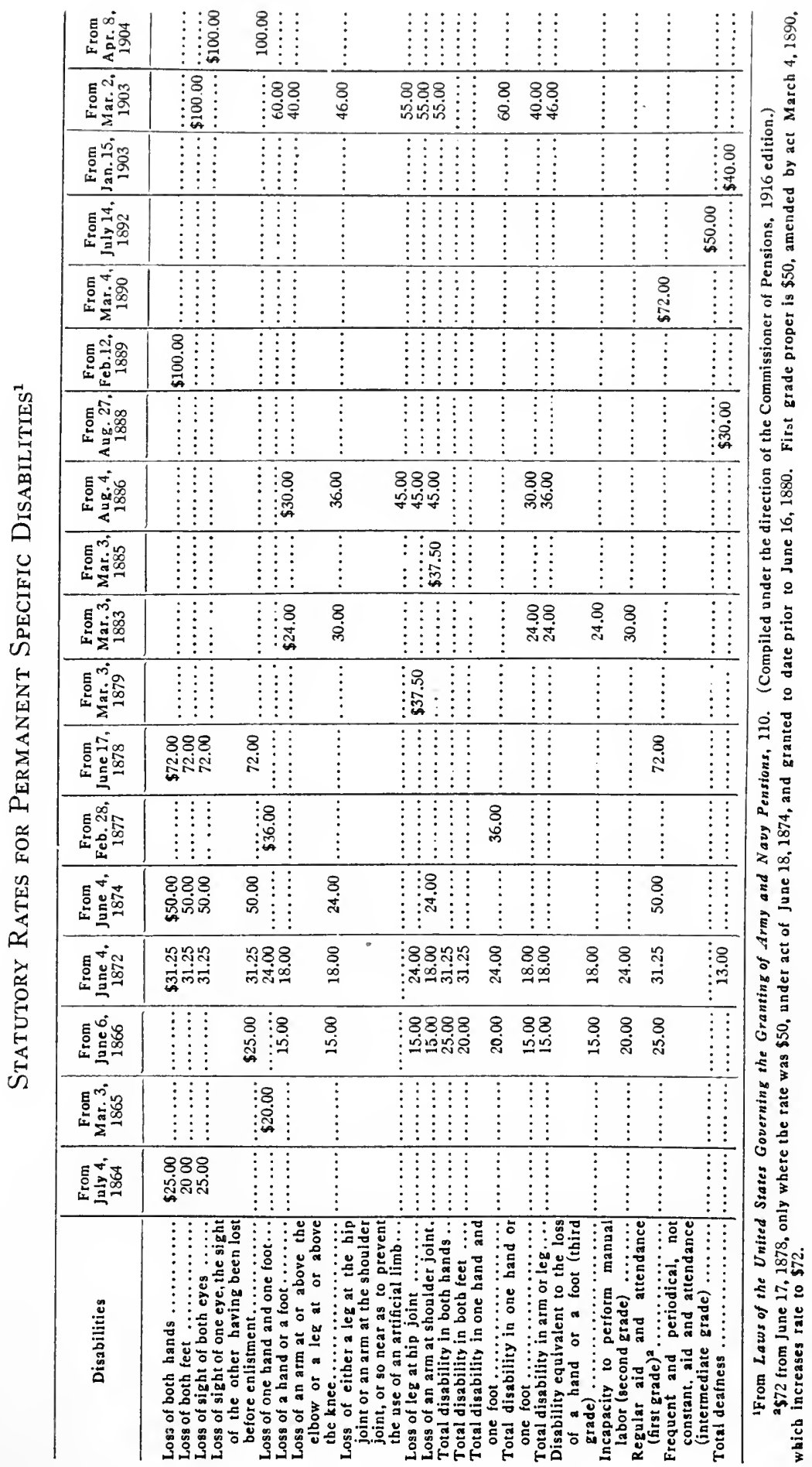


aggregate. Among the new provisions he mentioned were a rate of $\$ 13$ a month for total deafness, and a section permitting the rate of $\$ 18$ per month to be proportionately divided by the Pension Bureau for any degree of disability that should be established for which the second section of the proposed act made no provision. The second section reenacted the total disability rate of eight dollars a month for a private soldier contained in the act of July 14, 1862. Senator Pratt said that the proposed division of the $\$ 18$ rate (a Senate amendment) would meet "the claims of a large number of cases where the claimants are disabled to a greater degree than that for which pension is provided in the second section, but whose disabilities are not equivalent to the loss of a hand or foot. This section is proposed as a remedy, especially in the case of private soldiers for the wide difference between the rate of pension now fixed by law, eight dollars per month, and that provided for the disability arising from the loss of a hand or foot." Although this explanation was made to the Senate, there seems to have been no general appreciation of the great importance of the amendment, and the bill passed that body practically without debate. On the occasion of the adoption by the House of the report of the conference committee of House and Senate, Mr. Moore of Illinois observed that the Senate had added to the bill "a very liberal amendment, to which we accede, that there shall be a proportionate rating between eight dollars a month and eighteen dollars a month-a very liberal and just provision, as we think, and one which we had no reason to expect the Senate would adopt."1

After the "Consolidation Act" of 1873 had become law, the following was the general scheme of invalid-pension rates in force. For the highest grade of permanent specific disabilities the statutory rate remained at $\$ 31.25$ a month. The second grade of such disabilities was pensionable at $\$ 24$ a month, and the third grade (equivalent to the loss of a hand or foot) at $\$ 18$ a month. For total disability (at that time construed by the Pension Bureau to mean "total disability for the performance

1 Congressional Globe, 3d Sess., 42d Cong., Part 3, 1901. 
of manual labor requiring severe and continuous exertion") the rate (under the act of July 14,1862 ) of $\$ 8$ a month for a private soldier was retained. A new statutory rate of $\$ 13$ a month was in force for total deafness. And the Commissioner of Pensions was empowered to fix, in his discretion, rates amounting to some proportion of $\$ 18$ a month for any degrees of disability not sufficient to warrant the $\$ 18$ rate for which the $\$ 8$ "total disability" rate did not make provision.

The section in the Consolidation Act conferring the above rate fixing power upon the Commissioner of Pensions became Section 4699 of the Revised Statutes. Under it the Commissioner of Pensions has fixed a large number of rates for certain disabilities not specified by law. Examples of such rates are $\$ 17$ a month for loss of one eye, $\$ 10$ for anchylosis (stiffening) of elbow, $\$ 14$ for loss of middle, ring, and little fingers, $\$ 8$ for anchylosis of wrist, $\$ 8$ for loss of thumb, $\$ 4$ for loss of index finger, $\$ 6$ for loss of great toe, $\$ 2$ for loss of any other toe, and $\$ 10$ for loss of all the toes of one foot. The discretionary powers of the Pension Bureau were further increased by the act of August 27, 1888, which established a $\$ 30$ rate for total deafness and authorized the Secretary of the Interior to grant such proportion thereof in cases of partial deafness as he might deem equitable. Nine grades of such rates have been established ranging from $\$ 6$ a month for nearly total deafness of one ear or slight deafness of both ears to $\$ 27$ a month for deafness of both ears existing in a degree nearly total. ${ }^{1}$

The eight dollars a month "total disability" rate of 1862 is retained in the statutes but is now (1917) called a "simple total disability" rate. It is equivalent to the rate for the stiffening of a wrist or the loss of a thumb. But this does not tell the whole tale of the liberalizing of disability rates under the general law. The act of March 2, 1895, provides that "All pensioners now on the rolls, who are pensioned at less than six dollars per month, for any degree of pensionable disability, shall have their pensions increased to six dollars per month; and that, hereafter, when-

1 Lazes of the U.S. Governing the Granting of Army and Navy Pensions, $1916,111$. 
ever any applicant for pension would, under existing rates, be entitled to less than six dollars for any single disability or several combined disabilities, such pensioner shall be rated at not less than six dollars per month." 1 It appears from the tables in the pension reports that about 45,000 pensions were automatically increased under this law. ${ }^{2}$ After the passage of the act of 1895 the slightest disabilities recognized under the general law became pensionable at six dollars a month. Today a soldier who loses a toe in patrolling the Mexican border is entitled to a pension of six dollars a month for life; while the soldier who lost both feet in the Civil War could prior to 1864 receive only eight dollars a month. But, if the latter soldier is surviving today, he has received a pension of $\$ 20$ a month beginning with July 4, 1864; of $\$ 31.25$ a month from June 4, 1872; of $\$ 50$ a month from June 4, 1874; of $\$ 72$ a month from June 17 , 1878; and of \$100 a month from March 2, 1903.

Thus far the chapter has dealt with a class of pension claims under the general law system in which the task of adjudication is comparatively easy. The disabilities are of such a nature that their existence is easily ascertainable; the rates to be applied are definitely established by law or by the order of the Commissioner of Pensions. But when pension claims are based upon the allegation that diseases were contracted in the military service and have gradually caused disabilities from which claimants are now suffering, pension administration is a technical and difficult problem. Here is a field of obscurity and uncertainty in which the allowance of a pension in very many cases depends upon expert medical opinion of the pathological sequence of diseases.

For example, a claimant alleges that he is suffering from disease of the heart and from chronic bronchitis and that these diseases were brought upon him by causes originating in his army service. If it appears from evidence acceptable to the Bureau of Pensions that he was in good health when he entered the army, that he suffered from rheumatism during the period of

1 U. S. Statutcs at Large, xxviii, 704.

2 Reports of the Commissioner of Pensions for 1894 and 1895. 
his service, that he also had pneumonia while in the army, and that since his discharge he has had a weak heart and more or less trouble with his lungs, he will doubtless be held to have a good claim to a pension. This is true, even though for long years after his discharge from military service he was not disabled to such an extent as to prevent him from earning his living by his ordinary occupation. He may even now be earning an excellent living by other than hard manual labor.

After the existence of pensionable disabilities in the claimant has been established, the problem of rating must be dealt with. What rate shall be allowed for his disease of the heart and what rate for his chronic bronchitis? If he chances to have an old gunshot wound, that is a third disability to be considered and rated in determining the amount of his pension.

In rating such cases, the Pension Bureau has again acted under the authority of the provision of the Revised Statutes (Section 4699), whose origin has already been explained, that "the rate of eighteen dollars per month may be proportionately divided for any degree of disability established for which" the "total disability" rate of eight dollars per month makes no provision. The rates are fixed upon the evidence, and upon the results of medical examinations, on the basis of disability for the performance of manual labor. They range from six-eighteenths to seventeen-eighteenths, according to the degree of disability shown. When a disability is shown in excess of seventeeneighteenths and equivalent to the loss of a hand or foot, the rate is $\$ 24$ (third grade) ; but if the disability is not equivalent to the loss of a hand or a foot, even if it is in excess of seventeeneighteenths, no higher rate than $\$ 17$ a month can be allowed. ${ }^{2}$ It is clear that this rating of the disability caused by a chronic disease or diseases in terms of eighteenths of the disability for the performance of manual labor equivalent to the loss of a hand or

1 The third grade permanent specific disability rate was raised to $\$ 24$ a month by the act of March 3, 1883, but the act expressly provided that no change should be made in the $\$ 18$ a month rate which might be proportionately divided according to the terms of Section 4699 of the Revised Statutes, U.S. Statutes at Large, xxii, 453.

${ }^{2} A$ Treatise on the Practice of the Pension Bureau (Washington, 1898), 126. 
a foot must be a very technical and complicated matter. The variations in the character of the work done by the local boards of examining surgeons and by the medical examiners in ,Washington add to the difficulties of the problem. The more a simple minded layman penetrates into the obscurities of the system the more he is apt to regard the complicated practice of the Pension Bureau as likely to achieve either the arbitrary or the absurdand sometimes both.

The number of pensions granted under the general law for diseases has been much greater than the number granted for wounds of various kinds, amputations, and injuries received in battle. Though no recent official statistics of the disabilities for which pensions have been granted are available, Commissioner Black published a statement of classified facts upon this subject in his report for 1888. The following is an abridgment of this statement, covering the period of twenty-three years after the close of the Civil War:

Classification of All Disabilities for Which Pensions Were Granted TO JUNE $30,1888^{1}$

\begin{tabular}{|c|c|c|c|}
\hline D & $\begin{array}{l}\text { No. of } \\
\text { cases }\end{array}$ & Dis: & $\begin{array}{l}\text { No. of } \\
\text { cases }\end{array}$ \\
\hline nd shell & 117,947 & poisoning & \\
\hline & & f kidneys & \\
\hline wounds & & ele & \\
\hline & 41,049 & of spinal c & \\
\hline $\mathrm{m}$, & & disease 0 & \\
\hline. & & ... & \\
\hline & 23 & & 2,144 \\
\hline & 22 & Disease of scro & \\
\hline & & tes & 2,119 \\
\hline & 15 & $s$ of feve & \\
\hline & & f & \\
\hline & & & \\
\hline & & Si & \\
\hline & & ines & \\
\hline & & & \\
\hline ation & 5,3 & $\mathrm{Mu}$ & 1, \\
\hline & & of brain, including & \\
\hline & & y $\ldots \ldots$. & \\
\hline sal c & & ellaneous & 11. \\
\hline
\end{tabular}

Nore.-In many cases two or more disabilities exist in the same individual, as for example a gunshot wound, hernia, and rheumatism.

1 Report of the Commissioner of Pensions for 1888. House Ex. Docs., Vol. 12, 50th Cong., 2d Sess., 68-69. 


\section{General Law Widows and Dependent Relatives}

As has been set forth earlier in this chapter, the act of July 14, 1862 , provided that, in case an officer or private soldier died from causes due to his military service, his widow, or his orphan children under sixteen years of age, or certain other dependent relatives, should be entitled to the same pension as the officer or soldier would have received for total disability. This ranged from $\$ 30$ a month for a lieutenant colonel or officer of higher rank to eight dollars a month for a private soldier or sailor. Beginning with 1865, a series of acts made the general law system constantly more liberal in provisions for widows, children, and dependent relatives. ${ }^{1}$

After the passage of the act of July 27, 1868, the state of the law was about as follows: The widow of a private soldier who died from causes of service origin was entitled to a pension of eight dollars a month. Her pension was granted until remarriage or death. The widow was entitled to an additional payment of two dollars a month for each child of the deceased soldier under the age of sixteen years. Where there was no widow living and entitled to a pension, a single child under sixteen years of age was entitled to a pension of eight dollars a month. If there were more than one child under the age of sixteen years, the children were entitled to a pension equal in amount to that which, under the circumstances, would have been allowed to a widow.

If a deceased soldier left neither widow nor child, certain other dependent relatives were eligible in succession to receive the pension of eight dollars a month. In cases of this kind, the act of 1868 established the order of precedence as follows: "first, mothers; secondly, fathers; thirdly, orphan brothers or sisters under sixteen years of age," who were to be pensioned jointly if there were more than one. If the dependent mother and father were both living, the father was given the right to

${ }^{1}$ See acts of March 3, 1865, June 6, 1866, July 25, 1866, and July 27, 1868. $U$. S. Statutes at Large. 
succeed to the pension on the death of the mother. And, in case of the death of the father and mother, the dependent orphan brothers and sisters of the soldier under sixteen years of age were given joint title to the pension until they attained the age of sixteen years respectively; the pension to date from the death of the party who, preceding them, would have been entitled to the same.

The "Consolidation Act" of March 3, 1873, provided that in cases where the widow was dead or debarred from receiving a pension and there was only one surviving child, the child's pension should be increased two dollars per month. ${ }^{1}$ That is, the child was granted the amount to which a widow with one child would be entitled-ten dollars-rather than the eight dollar widow's pension rate. The provision also carried with it, in many cases, seven years' arrears of increase.

On March 19, 1886, an important increase act became law. ${ }^{2}$ It provided that the pensions of all widows, minor children, and dependent relatives already on the pension roll should be increased from eight to twelve dollars a month. Nothing in the act was to affect the existing allowance of two dollars per month for each child under the age of sixteen years. This law also provided that widows and dependent relatives who might thereafter be placed upon the pension roll should receive twelve dollars a month, with the limitation that the increase applied only to widows who were married to the deceased soldier or sailor prior to March 19, 1886, and to those who might thereafter marry prior to, or during, the service of the soldier or sailor. This increase of forty-eight dollars a year affected some 95,000 cases then on the rolls, besides claims allowed after the passage of the act.

As has previously been stated, a widow receives two dollars a month additional pension on account of each child under sixteen years of age. She may not be deprived of this additional allowance by reason of such children being maintained in whole or in

${ }^{1} U$. S. Statutes at Large, xviii, 566.

2 Ibid., xxiv, 5. 
part at the expense of the state or the public in any educational institution, or in any institution organized for the care of soldiers' orphans. In case a minor child is insane, idiotic, or otherwise permanently helpless, his or her pension continues during life or during the period of disability. ${ }^{1}$

The pensions of all general law widows, regardless of the date of marriage, were fixed at twelve dollars a month by the act of April 9, 1908," which provided that "the rate of pensions for widows, minor children under the age of sixteen years, and helpless minors as defined by existing laws, now on the roll or hereafter to be placed on the pension roll and entitled to receive a less rate than hereinafter provided, shall be twelve dollars per month; and nothing herein shall be construed to affect the existing allowance of two dollars per month for each child under the age of sixteen years and for each helpless child."

A further increase in the rate of widows' pensions was made by the act of September $8,1916 .^{3}$ This law provided that every widow who was the lawful wife of a soldier or sailor during the period of his service in the Civil War should receive twenty dollars a month. A pension at the same rate was also provided for Civil War widows upon attaining the age of seventy years. ${ }^{4}$

The law has done something to place obstacles in the way of mercenary marriages to aged Civil War veterans with the object of gaining title to a widow's pension. An act of March 3, 1899, provided that a widow who did not marry the soldier prior to the date of the act, or prior to or during his service, should have no title to a widow's pension unless it be shown that she lived and cohabited with him continuously from the date of marriage to the date of his death, or, in case of separation, that such sepa-

1 See Section 4703 of the Revised Statutes, Section 3 of the act of June 27, 1890 , and the act of May 9, 1900.

2 See pages 251 and 252 with regard to the operation of the act of April 9,1908 . It included widows under the act of June 27, 1890, whose husbands died of causes not of service origin. U. S. Statutes at Large, xxxv, 64.

${ }^{3}$ This increase applied both to general law widows and to widows under the act of June 27, 1890, and supplementary legislation.

4 Section 314 of the act of October 6, 1917, increased the pension rate for all Civil War and War with Spain widows to $\$ 25$ a month.

${ }^{5}$ U. S. Statutes at Large, $\mathrm{xxx}, 1380$. 
ration was through no fault of hers. However, the widows of Spanish War soldiers are excepted from the provisions of this act.

While the remarriage of any widow, dependent mother, or dependent sister, entitled to pension, causes her pension to be stopped it does not bar her right to receive the amount of the pension to the date of remarriage, even though she did not apply for the pension until after such remarriage. ${ }^{1}$ Such cases often involve the payment of large sums of arrears under circumstances which constitute an abuse of the bounty of the government.

A widow who has lost her pension by reason of remarriage may even be restored to the pension roll when she again becomes a widow. ${ }^{2}$ For many years prior to the passage of the act of September 8, 1916, the requirements for the restoration of a widow to the pension roll were that she had been the wife of the soldier during the period of his military service; that she was pensioned as his widow by reason of his death being due to disability of service origin; that her name was dropped from the roll by reason of her remarriage to another person who has since died, or from whom she was divorced upon her application, and without fault on her part; and that she was, at the time of her application, without means of support other than her daily labor and a net income not exceeding $\$ 250$ per annum. The act of September 8, 1916, made the provision for the restoration of widows to the pension roll even more liberal. At present, any widow of a Civil War soldier who has lost her pension by remarriage may, upon again becoming a widow or upon being divorced without her own fault, be restored to the roll at the rates now provided by law. ${ }^{3}$

1 Section 4708, Revised Statutes. See also act of June 7, 1888.

2 Information Relating to Army and Navy Pensions and Bounty-Land Warrants, 1915, 17. Also acts of March 3, 1901, and February 28, 1903, U.S. Statutes at Large, xxxi, 1445-1446; xxxii (Part 1), 920-921.

${ }^{3}$ Certain widows who remarried were barred from a pension by an act of March 3, 1865. Though they were not placed on the pension roll when the soldier husband died from causes due to his military service (being barred by their early remarriage), now after the death of the second or later husband they also are entitled to be placed on the pension roll at the rates established by law. 


\section{Double Pension for Death or Disability from Aviation Duty}

Congress has recently promised unusual pension benefits to certain persons who suffer as the result of accidents in aviation service. An act of March 3,1915, provided that in all cases in which an officer or enlisted man of the navy or marine corps dies or is disabled by reason of an injury received or disease contracted in line of duty, "the result of an aviation accident, received while employed in actual flying in or handling air craft, the amount of pension allowed shall be double that authorized to be paid should death or the disability have occurred by reason of an injury received or disease contracted in line of duty, not the result of an aviation accident." 1 This giving of double pensions for extra-hazardous military service is novel. An application to Congress for similar benefits for persons operating submarines would not be surprising. Obviously the law will provide pensions for both invalids and the dependent relatives of deceased aviators. ${ }^{2}$

The comprehensive general law pension system has been described in its essential features. In a matter so complicated, much of detail must necessarily be omitted. The provisions of the system have been applied to the Civil War, the various operations of the regular army and navy, the War with Spain and the Philippine Insurrection, and they apply likewise to the recent operations in and near Mexico. ${ }^{3}$

Prior to 1890 all pensions granted on account of the Civil

\section{U. S. Statutes at Large, $\mathrm{xxxviii,} 940$.}

2 The above paragraph was written before the passage of the act of October 6,1917 , which makes "existing pension laws" inapplicable to service after that date. No extraordinary compensation is provided in the new law for injury or death in aviation service.

3 Since this chapter was written, the United States has entered the European War. The armed forces of the United States engaged in the present war would have been entitled to the benefits of the general law pension system described in this chapter, if no superseding legislation had been enacted. But, on October 6, 1917, President Wilson approved a new law providing insurance, compensation, and other benefits for soldiers in the present war and their dependent relatives in case of death or disability due to military service. The old pension system remains in force as applied to military service rendered before the passage of the act of October 6, 1917. 
War were either under the general law system or by special acts passed for the benefit of favored individuals. Since the inauguration in 1890 of a system of Civil War service-pensions, with provisions constantly being made more liberal, the number of general law pensioners of the Civil War has rapidly declined. This is partly because of deaths and partly by reason of the transfer of pensioners from the list of invalids to secure higher pension rates under the terms of some of the later servicepension laws. In 1915 there were less than 102.000 pensioners of the Civil War under the general law, while about 590,000 were under the various service-pension acts-principally the acts of April 19, 1908, and May 11, 1912. Twenty years before, in 1895 , there were about 460,000 general law pensioners (including a few regular army pensioners) and 479,000 Civil War pensioners under the act of June 27, 1890. In the fiscal year 1890 - just before the Civil War service-pension system was inaugurated-there were 505,000 general law penșioners.

The following table gives the facts as to the number of general law pensioners and the expenditures in 1865 and every fifth year thereafter down to the present. It will be observed that since 1890 the number of general law pensioners has steadily declined.

General Law Pensioners Since 1865

\begin{tabular}{|c|c|c|c|c|c|c|}
\hline \multirow[b]{2}{*}{$\begin{array}{l}\text { Fiscal } \\
\text { Year }\end{array}$} & \multicolumn{3}{|c|}{$\begin{array}{l}\text { No. of General Law } \\
\text { Pensioners on Roll }\end{array}$} & \multicolumn{3}{|c|}{ Expenditures } \\
\hline & Invalids & $\begin{array}{l}\text { Widows } \\
\text { and De- } \\
\text { pendents }\end{array}$ & Total & Invalids & $\begin{array}{l}\text { Widows } \\
\text { and De- } \\
\text { pendents }\end{array}$ & Total \\
\hline 86 & $35,880^{*}$ & $48,989 \pi$ & 84 & $\$ 2,20$ & $\$ 6,109,730$. & $\$ 8,316,072.43$ \\
\hline & $521 *$ & & & & & \\
\hline 875 & $107,114 *$ & 106,66 & 213 & 11,93 & $15,860,406$ & .565 .56 \\
\hline 200 & 135,27 & & & & & \\
\hline & $244,201 *$ & 8 & 324,9 & 47,84 & 15,3 & $63.207,000.59$ \\
\hline 80 & 419,046 & 111, & 530 & 76,2 & & $104,571,848.32$ \\
\hline & & 102,6 & 459,8 & $59,382,212.01$ & 17,6 & $77,008,933.05$ \\
\hline & 602 & & 391,3 & $55,083,515.75$ & 14,4 & $69,557,033.46$ \\
\hline & 219,384 & 84,4 & 303,8 & $45,534,661.39$ & $13,489,908.88$ & $59,024,570.27$ \\
\hline 1710 & 121 & & 196,2 & $32,951,289.41$ & & $44,657,104.32$ \\
\hline 191 & 45,336 & 56,020 & 101,356 & $16,520,301.03$ & $8,965,970.28$ & $25,486,271.31$ \\
\hline
\end{tabular}

*Includes a small number of invalids of wars prior to the Civil War.

includes 2,013 widows and dependents of wars prior to 1861 .

$\$$ Report of 1890 incomplete.

IIncludes a small number of widows, etc., of wars prior to 1861 . 


\section{War with Spain and Philippine Insurrection}

Since the general law pension system extends indefinitely forward in its application, there was no need of new invalid-pension legislation for the War with Spain and the Philippine Insurrection. The liberal system of provisions for disabilities originating in actual military service, which had been developed in the thirty-three years since the Civil War, applied at once to the soldiers and sailors engaged in the hostilities with Spain. They were better protected in the matter of invalid-pension provisions than any other soldiers who had, up to that time, been called to the colors.

The following table gives the facts with regard to the number of pensioners and the expenditures on account of the War with Spain and the Philippine Insurrection from 1899 to 1916:

War with Spain and Philippine Insurrection Pensions Since $1899^{1}$

\begin{tabular}{l|r|r|r|r|r|r}
\hline & \multicolumn{2}{|c|}{ No. of Pensioners on Rolls } & \multicolumn{3}{|c}{ Expenditures } \\
\cline { 2 - 7 } $\begin{array}{c}\text { Fiscal } \\
\text { Year }\end{array}$ & Invalids & $\begin{array}{r}\text { Widows } \\
\text { and De- } \\
\text { pendents }\end{array}$ & Total & Invalids & $\begin{array}{c}\text { Widows } \\
\text { and De- } \\
\text { pendents }\end{array}$ & Total \\
\hline 1899 & 123 & 176 & 299 & $\$ 9,430.51$ & $\$ 19,176.30$ & $\$ 28,606.81$ \\
1900 & 882 & 873 & 1,755 & $156,807.94$ & $176,097.31$ & $332,905.25$ \\
1901 & 3,555 & 2,049 & 5,604 & $682,020.24$ & $493,205.52$ & $1,175,225.76$ \\
1902 & 6,611 & 2,854 & 9,465 & $1,175,178.61$ & $563,267.67$ & $1,738,446.28$ \\
1903 & 9,200 & 3,662 & 12,862 & $1,532,648.77$ & $671,435.44$ & $2,204,084.21$ \\
1904 & 12,440 & 4,389 & 16,829 & $2,237,024.57$ & $869,907.21$ & $3,106,931.78$ \\
1905 & 15,711 & 4,780 & 20,491 & $2,551,267.21$ & $858,731.33$ & $3,409,998.54$ \\
1906 & 17,646 & 4,975 & 22,621 & $2,603,721.87$ & $838,434.66$ & $3,442,156.53$ \\
1907 & 19,031 & 5,046 & 24,077 & $2,628,619.17$ & $842,538.10$ & $3,471,157.27$ \\
1908 & 20,548 & 5,117 & 25,665 & $2,804,849.66$ & $849,273.32$ & $3,654,122.98$ \\
1909 & 21,967 & 5,128 & 27,095 & $2,970,800.84$ & $849,368.96$ & $3,820,169.80$ \\
1910 & 22,783 & 5,106 & 27,889 & $2,970,601.92$ & $837,317.99$ & $3,807,919.91$ \\
1911 & 23,383 & 5,107 & 28,490 & $3,110,900.63$ & $840,350.62$ & $3,951,251.25$ \\
1912 & 23,841 & 5,009 & 28,850 & $3,130,991.22$ & $840,094.83$ & $3,971,086.05$ \\
1913 & 24,157 & 4,858 & 29,015 & $3,240,844.86$ & $830,323.56$ & $4,071,168.42$ \\
1914 & 24,250 & 4,660 & 28,910 & $3,132,372.53$ & $775,137.00$ & $3,907,509.53$ \\
1915 & 24,370 & 4,542 & 28,912 & $3,105,807.74$ & $745,893.73$ & $3,851,701.47$ \\
1916 & 24,101 & 4,371 & 28,472 & $3,076,733.88$ & $723,491.83$ & $3,800,225.71$ \\
\hline
\end{tabular}

1 Compiled from the reports of the Commissioner of Pensions. 


\section{Regular Army Pensions}

From the Civil War to 1904, regular army pensions were paid under the general law, and, the amounts being comparatively small, expenditures were not separately reported. In the following table are presented the number of regular army pensioners and the cost of their pensions for each year from 1904 to 1916 inclusive:

Regular Establishment Pensions Since 19041

\begin{tabular}{|c|c|c|c|c|c|c|}
\hline \multirow[b]{2}{*}{$\begin{array}{c}\text { Fiscal } \\
\text { Year }\end{array}$} & \multicolumn{3}{|c|}{ No. of Pensioners on Rolls } & \multicolumn{3}{|c|}{ Expenditures } \\
\hline & Invalids & $\begin{array}{l}\text { Widows } \\
\text { and De- } \\
\text { pendents }\end{array}$ & Total & Invalids & $\begin{array}{l}\text { Widows } \\
\text { and De- } \\
\text { pendents }\end{array}$ & Total \\
\hline 1904 & 9,501 & 3,231 & 12,732 & $\$ 1,610,413.84$ & $\$ 677,511.15$ & $\$ 2,287,924.99$ \\
\hline 1905 & & 3,403 & 3,433 & 1,72 & 69 & 2,4 \\
\hline 190 & & & & 1,8 & 708 & 10 \\
\hline & 11 & 3,615 & 1 & $1,897,963.48$ & $737,068.37$ & $2,635,031.85$ \\
\hline 190 & & 3,7 & & $2,016,853$. & $749,749.83$ & $2,766,603.21$ \\
\hline$i c$ & & 3,8 & & 2,1 & 77. & 2 , \\
\hline 15 & & 4,0 & 17 & $2,187,267$ & 813,723 & $3,000,990.12$ \\
\hline 1 & & & & 2,3 & 839 & $3,197,834.19$ \\
\hline 191 & 14 & 4,3 & 18 & $2,433,074.20$ & $875,301.11$ & $3,308,375.31$ \\
\hline 101 & & 4,3 & & & 886,76 & $3,447,141.88$ \\
\hline & & 4,412 & & 190.51 & 893,9 & $3,475,147.69$ \\
\hline 191. & & 4,4 & & 2,6 & & $3,535,891.56$ \\
\hline 191 & & 4,5 & 20,102 & $2,711,946.09$ & $913,964.15$ & $3,625,910.24$ \\
\hline & int 1 & & & $\$ 28,627,770.42$ & 04 & 9.01 \\
\hline
\end{tabular}

* For the first time the number of pensioners in the regular establishment was given separately in 1903, invalids 9,170, and widows, 2,938 (Report of Commissioner of Pensions, 1903, p. 16), but it was not until the fiscal year 1904 that the amount paid out was listed separately.

† These totals represent the expenditure under the regular establishment from the time it was listed separately, 1904. Previously, the regular establishment was included under the general law.

In closing this account of the general law pension system, the emphasis should not be placed upon the difficulties and abuses in administration, but upon the essential justice of the principle upon which the system is based. Those who are called upon to take up arms and risk their lives in the defense of the state ought to be cared for generously in case they are disabled by wounds

1 Compiled from the reports of the Commissioner of Pensions. 
or other injuries received in the performance of their military duties. When soldiers make the supreme sacrifice of their lives in military service, every sentiment of honorable obligation and gratitude approves provisions by the state of pensions or other assistance for widows and dependent relatives. An invalidpension system is in accord with justice and sound public policy. The more such a system can be freed from abuses, inequalities, and frauds, the larger will be the funds available for the deserving and the more equitable the distribution. Opposition to unnecessary service-pensions to those who were not disabled in the army is calculated to conserve the funds of the state for more liberal payments to the invalid-pensioners. Throughout American history the payment of invalid-pensions has received general public approval. In the matter of Civil War pensions, there has been very little objection to a constant increase in the invalidpension rates. The most serious evils that have arisen have been in connection with the service-pension system described in a later chapter. The country does not wish to do less for soldiers disabled in the line of duty and for the dependent relatives of those who are killed, but a better system is needed in order that pension funds may be distributed with greater equity and with less waste. 


\section{CHAPTER II}

\section{Civil War Pensions-Arrears Legislation-Pensions and Politics}

Early in the seventies the number of federal pensioners and the annual pension disbursements appeared to have reached a maximum, provided no important changes were made in the laws. In explaining the pension appropriation bill for the fiscal year 1874, General Garfield, chairman of the Committee on Appropriations, said in the House of Representatives on December 12, 1872:

It is interesting to inquire what the tendency of our pension appropriation is likely to be from year to year. From the figures I have just stated it will be seen that there has been a steady increase for several years. It is thought by the Commissioner of Pensions that we have now reached the top, so far as the amount of expenditure is concerned; but he does not think that that top is a peak from which we will at once descend, but rather a plain upon which we will go for perhaps several years with a substantial regularity of amount about the same as we are now paying per annum. ${ }^{1}$

The view presented to the House in General Garfield's remarks was an excellent forecast of the immediate future. In 1874 the disbursements for pensions reached the highest amount ever experienced up to that time, but the pension list decreased in numbers from the previous year for the first time since 1862 . The following table shows that the period immediately after 1874 was one of slow decline in number of pensioners and in disbursements:

Fiscal year

$1873 \ldots \ldots \ldots \ldots$

$1874 \ldots \ldots \ldots \ldots$

$1875 \ldots \ldots \ldots \ldots$

$1876 \ldots \ldots \ldots \ldots$

$1877 \ldots \ldots \ldots \ldots$

1878
Total disbursements for pensions

$\$ 26,982,063.89$

$30,206,778.99$

$29,270,404.76$

$27,936,209.53$

$28,182,821.72$

$26,786,009.44$
Total number of pensioners

238,411

236,241

234,821

232,137

232,104

223,998

${ }^{1}$ Congressional Globe, 42d Cong., 3d Sess., Part I, 167. 
Never since 1878 have the number of pensioners and the annual disbursements been at so low a level as in that year.

Beginning as early as 1870 , there was also a notable falling off in the number of original claims presented on account of service in the Civil War. The number of original claims filed under the general law-practically all Civil War claims-was 24,851 in $1870 ; 18,154$ in $1871 ; 16,030$ in $1872 ; 15,523$ in 1873 ; and 15,284 in 1874 . From 1871 to 1873 , the claim agents were busy pressing applications under the War of 1812 pension act of 1871. After these were disposed of, they displayed greater activity in stimulating new Civil War claims. In such efforts they were doubtless materially assisted by the greater liberality of the general law rates after the passage of the "Consolidation Act" of 1873. The number of original Civil War claims filed in 1875 was 17,708 ; in $1876,22,768$; in $1877,22,169$; and in 1878 , 25,904 . But, despite the best efforts of the pension attorneys, new applications were more and more difficult to secure, and to prevent the loss of their lucrative business they began an aggressive agitation for new legislation. ${ }^{1}$

In his annual report for 1878, Commissioner of Pensions Bentley gave considerable attention to the methods used by the pension attorneys in persuading persons to file claims. He said that the country was being continually advertised and drummed from one end to the other by claim agents in pursuit of persons who had honest claims, or of those who were willing, in consideration of the fact that it would cost them nothing unless they won their pensions, to file claims that had no merit, leaving it to the ingenuity and cupidity of their agents to "work" the cases through. The Commissioner also called attention to the fact that professional claim agents and claim firms at Washington and other points were advertising their business by "employing for that purpose in some instances sheets issued in the form of periodical newspapers purporting to be published in the interest

1 The facts in this paragraph as to original Civil War claims filed in various years are compiled from the Report of the Commissioner of Pensions for 1898 , Table No. 11, p. 33 . 
of the soldiers, the columns of which contained matter in which apparent anxiety for the soldiers' welfare and appeals to their love of gain were cunningly intermingled." 1 These sheets always represented the advertisers as in the enjoyment of special and peculiar facilities for the successful prosecution of claims, and often added the suggestion that no charge would be made unless a pension should be obtained. The advertisements contained in such journals and their continual agitation for new pension laws had an undoubted effect in producing a demand for more liberal allowances among the old soldiers and their families throughout the country.

In their efforts to give a new impetus to the expansion of the pension system, the claim agents made use of "arrears" as a rallying cry with which to attract the support of the veterans and their widows. Many persons who were discharged from the army during the Civil War had not applied for pension. Some had not applied until many years after discharge. To understand the significance of the agitation for arrears, take the case of a soldier who was discharged from the army in 1864 . If he applied for a pension in 1877 and proved to the satisfaction of the Pension Bureau that he was suffering from disease which

\footnotetext{
1 Although there were a number of such publications, doubtless Commissioner Bentley had particularly in mind George E. Lemon and the National Tribune. This publication was started in Washington in October, 1877, by Mr. Lemon, a lcading pension attorney. Appearing at first monthly and later weekly, it professed devotion to the interests of soldiers and pensioners. It also included considerable reading matter of a literary and historical nature. Advertisements of Mr. Lemon's business were prominently displayed. The National Tribune championed and urged upon Congress an extensive program of pension legislation. It undertook to watch the work of the Pension Bureau in the interest of pensioners and pension claimants. From its first number, Mr. Lemon's publication entered upon an ardent campaign for arrears of pension legislation. It also contained flattering editorial praise of the efficiency of Mr. Bentley as Commissioner of Pensions and urged that his salary ought to be increased. When $\mathrm{Mr}$. Bentley insisted upon the advocacy of plans for reforms in pension administration, the National Tribune turned upon him and attacked him persistently and bitterly. The journal had a rapid growth in circulation, and its political influence was not to be despised. On January 15, 1885, Mr. Lemon testified before a committee of the House of Representatives that the National Tribune was then a weekly journal, going to between 18,000 and 19,000 post offices and having 112,000 paid subscribers. It is still published in 1916. See House Reports, 48th Cong., 2d Sess., 1884-1885, Report No. 2683, 16.
} 
originated in military service, he might be granted a pension to commence from the date of filing the last evidence necessary to establish his claim. Possibly he might be rated at eight dollars a month. The contention of the advocates of arrears payments was that he should be paid, upon the allowance of his claim, back pension dating from the time of his discharge from the army and at the same rate per month as that at which the pension was originally granted. In this hypothetical case, if the proposed arrears law were enacted, the pensioner would receive $\$ 1200$ or $\$ 1300$ in a lump sum at the time he received the first payment on his pension.

In cases where claims had already been allowed and the pensions had been paid only from the date of filing the last evidence, the arrears bill required the government to reopen the matter and to pay the pensioner the arrears for the intervening time between the actual commencement of his pension and the date of his discharge from the army. Thus the proposed measure involved the payment out of the Treasury of a very large amount of arrears on claims that had already been allowed. And there were a great many thousands of claimants interested in participating in the lavish distribution. Another more important feature of the arrears measure was its application to new claims. It offered what amounted to a large cash premium on the establishment of original claims. The temptation to an old soldier to allege that he had a disability which originated in military service was made exceedingly strong. Once a claim was filed, delay in the adjudication operated to increase the amount to be paid in cash if the claim were finally successful. There was great inducement to spare no means, right or wrong, to bring about favorable action by the Pension Bureau. The arrears proposition was before Congress in several different forms. The various bills did not agree as to whether arrears should be granted on all claims to be established in the future or upon only those claims which should be filed with the Pension Bureau before a certain date after the passage of the law.

It is important, in passing upon the expediency and justice of 
the movement for an arrears act, to review the provisions of law which had been in force since 1862 with regard to the commencement of pensions granted on account of service in the Civil War. The act of July 14, 1862, provided that invalidpensions should commence from the date of discharge in all cases in which the application should be filed within one year after that date; otherwise the pension was to commence from the date of filing the application. Pensions to widows and dependent relatives were to commence, without limitation as to the date of application, from the death of the soldier on whose account the pension in question was granted. Further provisions regarding the commencement of pensions were made in 1864 and 1866 , and the whole matter was left in a state neither clear nor satisfactory. Without going into confusing details, it is enough to point out that under the existing provisions there was danger of unjust discrimination between claims of equal merit.

Previous provisions regarding the time from which Civil War pensions should commence were superseded by section six of the act of July $27,1868 .^{1}$ This section provided that all pensions which had been granted, in consequence of death occurring, or disease contracted, or wounds received, since March 4, 1861, or which might thereafter be granted, should commence from the discharge or death of the person on whose account the pension had been, or might be, granted. In order to secure the benefits of this provision, it was required that applications for pensions should be filed with the Commissioner of Pensions within five years after the right thereto had accrued; but applications by, or in behalf of, insane persons and children under sixteen years of age might be filed after the expiration of the five years, if previously they were without guardians or other legal representatives. This extension of the time for presenting Civil War pension claims caused the payment of many millions of dollars of arrears, ${ }^{2}$

1 U. S. Statutes at Large, $\mathrm{xv}, 236$.

2 The arrears paid in the fiscal year 1872 alone amounted to between $\$ 4,000,000$ and $\$ 5,000,000$. Report of the Commissioner of Pensions for 1872, House Ex. Doc., 42d Cong., 3d Sess., Report of the Secretary of the Interior, i, 326. 
but it served to establish a definite and liberal basis for the commencement of pensions.

The important Consolidation Act of March 3, 1873, provided, similarly to the act of 1868 , that a pension should commence from the death or discharge of the person on whose account the claim had been, or should thereafter be, allowed, or from the termination of the right of the party having prior title to the pension, provided that the application had been, or should be, filed within five years after the right to pension had accrued. Otherwise the pension was to commence from the date of filing the last evidence necessary to establish the claim. This five years' limitation was subsequently embodied in the Revised Statutes, and remained in force until the passage of the Arrears Act of 1879.

Was the law as it stood in 1873 substantially just to the soldier or to the soldier's widow?

Commissioner of Pensions Baker wrote in his report for 1872:

The claims presented during and immediately after the close of the war were chiefly for wounds or injuries received or disease which disabled the soldier from returning to his accustomed vocation in civil life; while those made in later years are largely on account of disease which developed to a disabling extent some time after his return from the Army, and are of somewhat doubtful origin. ${ }^{1}$

The period of five years, prescribed by the act of 1868 and the Consolidation Act, seems to have been entirely sufficient to afford a soldier opportunity to discover whether or not he was suffering from any disability caused by military service, and, in case he had a disability, to file an application for an invalidpension. If he did not file such an application within the five years after his discharge from the army, it is reasonable to suppose (except in cases of insanity or incompetency) that he either

1 Report of the Commissioner of Pensions for 1872. House Ex. Doc., 42d Cong., 3d Sess., Report of Secretary of Interior, i, 325. 


\section{FEDERAL MILITARY PENSIONS IN THE UNITED STATES}

did not desire a pension or that he was not at the time conscious of a disability such as would warrant a claim. If later he decided to apply for a pension, or was induced to do so by the representations of a pension attorney, it is hard to see any sound reason why, upon the allowance of his claim, he should receive payment of arrears from the date of his discharge from the army.

In such a case as that used in the above illustration, something might be said in favor of paying the pension, if granted, from the date of filing the application rather than from the date of completing the evidence. The objection to paying the pension from the date of filing the original application is that it gives opportunity for abuses when claims are long pending and of a doubtful character, or when they have once been rejected and are later revived on the plea of new evidence. In cases of this character, there is strong incentive to complete the evidence by questionable or fraudulent means in order to obtain arrears from the date of the original application. It was doubtless for reasons of this nature that the acts of 1868 and 1873 provided that, when claims were presented and allowed after the expiration of the five year period, the pensions should commence from the date of filing the last evidence.

The application of the five year limitation to widows' claims seems also to have been reasonably liberal. That period of time after a soldier's death gave his widow abundant opportunity to present her claim in all cases in which the death was clearly due to causes which originated in military service. A later presentation of a claim would usually mean either that the widow had not been in immediate need of a pension or that there was no clear or certain connection between the soldier's death and his military service. The possibility of establishing such a connection might be suggested to a widow long years after her husband's death, and the suggestion might lead her to endeavor to prove that some illness or exposure in army service had gradually brought on the disease of which he died.

An hypothetical case, fairly representative of many real ones, 
may be used as an illustration. A soldier was discharged from the army in 1864 . He married in 1865 and was able to support himself and wife by his usual occupation. After a few years he was in poor health, and in 1871 he died of tuberculosis, never having applied for a pension. Not connecting his death with army service, his widow filed no application within the five year period. However, in 1878, she was informed that she could probably establish a valid pension claim. She filed an application and secured evidence that her husband suffered from a severe attack of bronchitis while in the army, and that he was unusually susceptible to colds after his discharge. A combination of military, medical, and lay testimony connected the tuberculosis from which her husband died with the attack of bronchitis as a cause. The Pension Bureau allowed the claim and placed the widow on the roll at eight dollars a month to commence with the date of filing the last evidence in the case.

If the widow described in this hypothetical case had filed her claim in 1876, before five years had elapsed since her husband's death, she might have received arrears of pension from the date of the soldier's death in 1871 to the date of the final allowance of the claim-a lump sum of about $\$ 500$. The contrast in the settlement obtained by a widow who filed her application within the prescribed time limit and that obtained by a widow who applied after the expiration of the five year period was undoubtedly calculated to produce a feeling of dissatisfaction in the mind of the latter.

The advocates of an arrears of pension bill held that the discrimination against the tardily filed claims was unjust. They urged that the government should provide for the payment of the arrears to all pensioners already on the rolls who had been barred by failure to apply for a pension within the time limit. Even more important, they desired that claims successfully prosecuted in the future should carry arrears from the date of the discharge or death of the soldier. There was some difference of opinion as to whether all future claims should carry arrears or whether a limit should be enacted after the expiration of which no further claims for arrears might be presented. 
Many arrears bills were proposed in Congress before one finally became law. Such a measure was introduced in the House of Representatives at the first session of the 43d Congress in December, 1873. ${ }^{1}$ Though favorably reported from the Pension Committee, it was not debated on its merits and did not pass. Early in the 44th Congress a number of bills granting arrears were introduced in the House. A substitute was reported in March, 1876, which ordered the payment of arrears provided applications were filed before January 1, 1880. Beginning with January, 1877, petitions and resolutions in favor of the arrears bill were presented from citizens of many states and from the legislatures of Illinois, Indiana, and West Virginia. On the last day of the second session, March 3,1877, the House took up the arrears bill under suspension of the rules and passed it without debate. $^{2}$ In the Senate, the bill was ordered to lie on the table on motion of Senator Ingalls, chairman of the Pension Committee. $^{3}$

The failure of the arrears measure to become law in the 44th Congress was only a temporary check to its advocates. In Washington the claim agents were busy sending out literature and letters throughout the country. Their aim was to stimulate such a demand for arrears among the old soldiers as would cause them to bring pressure upon their Senators and Representatives in Congress. Blank petitions were sent out to be signed and returned for presentation to Congress. In October, 1877, George E. Lemon began the publication of his National Tribune which gave arrears a prominent place in the lavish program of pension legislation which it advocated. Another claim agent, N. W. Fitzgerald, utilized his paper the Citizen Soldier, to agitate for

${ }^{1}$ Cong. Record, 43d Cong., 1st Sess., Part 1, 205; Part 3, 2133.

2 Ibid., 44th Cong., 2d Sess., Part 3, 2222.

${ }^{3}$ Ibid., 2168. Senator Ingalls had, however, given his personal approval to the principle of arrears when he said in the Senate on March 9, 1876: "So far as I am concerned personally, and so far as the Committee on Pensions are concerned, I believe that we agree that there is no reason in the nature of things why a pension, if it is to be granted at all, should not date from the period when the disability accrued or when the death of the person occurred for which the survivor claims the benefit of the law." 
arrears. These were but two of many claim agents' publications enlisted in the cause. A prolonged lobbying campaign was conducted in Washington by a claim agent, Captain R. A. Dimmick, who acted as the representative of a Committee of Pensioners which he had himself organized. He solicited and received contributions in aid of his work. After the Arrears Act finally became law, he asserted that its passage was due to his efforts. With the assistance of several government employes and claim agents who had been associated with him, he sought to raise by subscriptions from the many thousands of pensioners benefited a money testimonial as a reward for his services. The appeal for such subscriptions, which was sent out to the pensioners of the country in the form of a circular letter, was supported by ten firms of pension attorneys. ${ }^{1}$ Before a great amount had been raised, the matter came to the attention of Congress and was made the subject of an investigation. This brought out the testimony of Dimmick and his associates as to their activities in behalf of the arrears bill.

Whether as a result of the labors of Dimmick and the claim agents or from other causes, a number of arrears bills were introduced into the House and Senate at the first (special) session

1 These pension attorneys certified "that to Capt. R. A. Dimmick, of this city, is entirely due the management and direction of the prosecution of the arrears of pension bill, which has become a law, and to him especially every pensioner is indebted for the success which has crowned his efforts." Captain Dimmick was also strongly endorsed in a certificate signed by George Bancroft. But, upon investigation, it turned out that this Bancroft was 2 pension claim agent and not the eminent historian.

Dimmick testified before the committee of the House of Representatives that he had been "educating the legislators." He had presented petitions, interviewed members, prepared pamphlets and circulars, written articles and editorials for newspapers, and organized pensioners in support of the demand for arrears. Two of his associates testified that they had called on President Hayes to talk to him about the arrears bill. Through Senator Matthews they had had a document and tabulation in support of their claims printed in the Congressional Record.

In its report the House Committee condemned Dimmick and his associates as "sharpers" who were attempting "to extort money from pensioners under the pretense of services by one of their number in securing the passage of the bill granting arrears of pensions." Dimmick and others were suspended as pension attorneys authorized to prosecute claims before the Pension Bureau. Report of the Committee on Expenditures in the Interior Department accompanied by the Testimony, (March 3,1879,) House Report No. 189,45 th Cong., $3 \mathrm{~d}$ Sess., 1 to 103. 
of the 45th Congress. The House was Democratic, Randall having been elected Speaker over Garfield by 149 to 132 . During the second session, Mr. Rice of Ohio, Chairman of the Committee on Invalid Pensions, reported on February 13, 1878, a bill favored by his committee as a substitute for various arrears bills which had been introduced at the first session. ${ }^{1}$ No action having been taken, on April 1, 1878, Mr. Cummings, a Republican from Iowa, made a motion to suspend the rules and pass a bill which he sent to the clerk's desk to be read. It proved to be another arrears bill. Mr. Rice and others sought to delay action by motions to adjourn. The House refused to adjourn. No debate being in order under a motion to suspend the rules and pass a bill, the vote was taken and resulted : yeas, 146; nays, 76 ; not voting, 69 . Two-thirds not voting in favor of the motion, it was defeated. ${ }^{2}$ But only two votes were lacking of the two-thirds necessary to pass the bill without a word of debate. Even Mr. Rice and other Democrats who had sought to adjourn the House voted "yea" on the bill. Some powerful influence must have been feared when so large a part of the Democratic majority in the House voted to ignore the Committee on Invalid Pensions and its report, and to pass in arbitrary fashion a bill suddenly brought forward by a Republican member. After his narrow defeat, Mr. Cummings the next day introduced the same bill by unanimous consent, and it was referred to the Committee on Invalid Pensions.

Whether through iack of ardor for the cause of arrears or by reason of the pressure of other business, Mr. Rice had failed to secure action on the committee bill when the end of the session arrived. On the last legislative day of the session, June 19, 1878, Mr. Haskell, a Republican from Kansas, got the floor, moved that the rules be suspended, that the committee be discharged from consideration of the Cummings bill, and that it be passed. This time the motion to suspend the rules was successful, and the bill was passed with the following amendment: "No claim agent or other person shall be entitled to receive any compensa-

${ }^{1}$ Cong. Record, 45th Cong., 2d Sess., Part I, 996.

2 Ibid., Part 3, 2157, 2217. 
tion for services in making application for arrears in pensions." The vote was 164 to 61 , with 65 not voting. ${ }^{1}$ Negative votes were almost entirely confined to Southern and border state members. No information was given the House except that the bill was not the one reported by the Committee on Invalid Pensions. Mr. Rice said that he had tried to get action on the committee bill and failed. He voted for the Cummings bill. Later there was a controversy in the newspapers as to the parts played by $\mathrm{Mr}$. Cummings and Mr. Rice in passing the arrears measure through the House. ${ }^{2}$ The bill was sent over to the Senate where it was referred to the Committee on Pensions. The session was ended on the same day, and the bill remained in committee. ${ }^{3}$

\section{Cong. Record, 45th Cong., 2d Sess., Part 5, 4874-4875.}

2 Since Mr. Cummings' bill finally became law, it is interesting to note the substance of his testimony before the House committee which investigated the lobbying and other activities of Captain R. A. Dimmick. Captain Dimmick had testified that he formerly resided in Iowa in the district which $\mathrm{Mr}$. Cummings represented. His family continued to reside there. He had spoken to Mr. Cummings several times in relation to the arrears measure, and particularly with regard to getting the Senators from Iowa to vote for the bill.

Mr. Cummings related the circumstances under which his bill was presented to the House originally and failed to get a two-thirds vote for suspension of the rules. He said that neither Dimmick nor any other person spoke to him about getting up that bill. The newspapers charged that it was a "lobby bill." On account of these charges he had the bill amended so that no claim agent should have any fees. Dimmick "never saw me until after I introduced the bill. He came to me as a friend of the measure and talked with me several times about it." After the bill had passed the House, he [Dimmick] "said that he knew there was a job being put up to defeat it, and that he should speak to our Senators. He never suggested anything improper to me, and I do not know that he has done anything of the kind." House Report No. 189, 45th Cong., 3d Sess., 70-72, 95-96.

3 The Senate had passed on June 4, 1878 (the date of the meeting of the G. A. R. encampment at Springfield, Mass.), an arrears measure of a much more conservative character than that of the House. The existing law was that pensions should commence from the death or discharge of the soldier in all cases in which the application was filed within five years from the time the right to the pension accrued. In cases not filed within five years, the pension commenced from the date of filing the last evidence necessary to prove the case. The Senate bill provided that in the latter class of cases all pensions which had been granted, or which should thereafter be granted, should commence from the date of filing the application rather than from the date of filing the last evidence. It was estimated that this change would involve the payment of $\$ 4,500,000$ for arrears. The bill passed the Senate without opposition, but the more liberal House bill supplanted it in the next session. Cong. Record, 45th Cong., 2d Sess., Part 4, 4063 . 
In connection with the fact that the arrears measure passed the House by so overwhelming a vote on June 19, 1878, it is worth noting that the bili had received public endorsement about two weeks before in the annual address of General John C. Robinson, commander-in-chief of the Grand Army of the Republic, at the twelfth annual encampment at Springfield, Mass., on June 4. He said that he had been struck with the justice of the measure, and that he had immediately brought it to the attention of the department commanders, hoping that action by the several department encampments might have an important bearing on its success. ${ }^{1}$ However, the Grand Army was at this time much less active in pension matters than it became in later years. It does not appear prominently in the campaign for the Arrears Act.

The advocates of arrears exerted themselves at the third session of the 45th Congress, beginning in December, 1878, to secure favorable action by the Senate on the Cummings bill which had passed the House. A steady stream of petitions for the House bill came before the Senate from day to day. On January 9, 1879, Senator Matthews of Ohio presented a petition on the subject of arrears from "the executive committee of the Pensioners' Association." He said that "in conformity with the request of these gentlemen who represent the great body of the pensioners throughout the country" he asked unanimous consent to have the petition read at the clerk's desk and incorporated in the Record. No objection was made. The petition included a former estimate made by the Pension Bureau of the amount needed to pay arrears to January 1,1876 . Basing their estimates on this report, the memorialists urged that fifteen millions of dollars would suffice to pay the arrears provided by the House bill. They said that six state legislatures and numerous organizations had recommended the passage of the bill and that petitions of over two hundred thousand citizens to the same effect had been filed in Congress. The passage of the act was urged "in behalf of honesty, equity, justice and morality, and in uphold-

1 Procedings of the I2th Annual Meeting of the National Encampment, G. A. R., 521 . 
ing and maintaining the national faith which has been pledged to the payment of this just debt."'

One's faith in the high sentiments and representative character of the above "Pensioners' Association" is shaken when it is found that four out of the five persons signing as members of its executive committee were associates of Captain R. A. Dimmick in his lobbying operations and in his attempts to raise for hinself a testimonial fund among pensioners after the arrears measure became law. At the investigation of Captain Dimmick, it appeared that he prepared the petition which Senator Matthews had printed, and that the Pensioners' Association purported to be an Ohio organization. ${ }^{2}$

In January, 1879, many Senators were coming before the legislatures of their states for reelection. Fear of political attacks at such a time was probably a motive with some Senators for supporting the arrears bill. Senator Ingalls, chairman of the Pension Committee, was attacked in his state, Kansas, where the pension interest was strong. Circular letters were sent to members of the legislature, under the seal of a Soldiers' and Sailors' Association, with the purpose of preventing his reelection. In this effort the busy Captain Dimmick was a participant, saying that Senator Ingalls could not be reached easily and that he seemed not to be friendly to the soldiers and sailors. ${ }^{3}$ The Senator had a particularly hard fight on his hands in the Kansas legislature, charges of corruption being made in connection with his reelection. However, an investigating committee exonerated him from guilt on these charges. Whether or not he was influenced by the attacks being made on him because of alleged

${ }^{1}$ Cong. Record, 45th Cong., 3d Sess., Part 1, 373.

2 The signers of the petition were Messrs. Burger, Trembly, Brower, Sadler, and Knight. Burger was in the War Department, where he had access to the rolls of certain regiments. Trembly was a messenger in the War Department. Brower was a clerk in the Pension Office. Sadler was a resident of Ohio whom Captain Dimmick had met while attending a pensioners' convention at Urbana, Ohio, in 1878. Sadler came to Washington in the interest of the arrears bill while it was before the Senate. Knight is unplaced. House Report No. 189, 45th Cong., 3d Sess.

${ }^{3}$ Housc Report No. 189, 45th Cong., 3d Sess., 69. 
lack of sympathy with the soldiers and pensioners, it is the fact that Senator Ingalls brought the arrears bill before the Senate and championed its passage on January 16, 1879, not long before balloting began in the Kansas legislature. ${ }^{1}$ When claim agent Lemon sent out the January number of his National Tribune, announcing joyfully that the arrears bill had passed House and Senate, he said of Senator Ingalls: "The pensioners are greatly indebted to Senator Ingalls, of Kansas, for his untiring efforts and labor in behalf of this bill, and he has earned and deserves the friendship and support of every soldier as well as every patriotic citizen."

The Senate debate on the arrears bill was most inadequate. Mr. Ingalls, who was in charge of the bill, gave no clear and definite information as to what it might be expected to cost. $\mathrm{He}$ expressed the opinion that from $\$ 18,000,000$ to $\$ 20,000,000$ would be required to pay arrears on claims that had already been allowed, but the Senate was left entirely in the dark as to the possibilities of the measure in stimulating new claims by its provision that arrears should be paid on all claims to be allowed in the future. No official estimate or statement of the cost of this arrears bill was before the Senate at all, but an estimate prepared by the Bureau of Pensions for another and different bill was utilized to some extent. ${ }^{3}$ The advocates of the bill gave Senators the impression that it would take not more than $\$ 20,000,000$ from the Treasury. They defeated an intelligent attempt to amend the loose and vague phraseology of the bill to prevent pensioners receiving arrears over any period of time during which they were

1 The legislature of Kansas met on January 13, 1879. Balloting for United States Senator began on January 28 , and Mr. Ingalls was reelected on January 31. On the first ballot Mr. Ingalls had only 60 out of 164 votes cast. There was undoubtedly corruption in the election, but Senator Ingalls was personally exonerated by a majority of the House investigating committee of the legislature and also by a committee of the United States Senate. Appleton's Annual Cyclopaedia for 1879, 532-533 (N. Y., 1880).

2 National Tribune, January, 1879, 5.

${ }^{3}$ On this point, see interview with ex-Commissioner Bentley in New York Herald, Dec. 15, 1881, p. 10, column 1. 
not in fact disabled. The measure passed the Senate as it came from the House by yeas, 44 ; nays, 4 ; absent, $28 .{ }^{1}$

Having been approved by overwhelming majorities in a Democratic House of Representatives and a Republican Senate, the arrears bill was sent to the President. While the measure was under executive consideration, Secretary of the Treasury Sherman, Secretary of the Interior Schurz and other public men expressed serious misgivings as to its probable effects. According to the New York papers, the measure was the subject of lengthy discussion in cabinet meetings, Secretary Sherman estimating that the bill would call for $\$ 150,000,000$ and that, if such an amount should go out of the Treasury, a deficit would be created. Secretary Schurz was reported as offering an estimate, based on figures furnished by Commissioner of Pensions Bentley, that the arrears would take about $\$ 50,000,000 .^{2}$ The merits and demerits of the bill were the subject of much discussion in the press of the country. News dispatches to the New' York Tribune said that the petitions for the measure which had come to Senators and Representatives were gotten up in response to circulars sent out by the thousand by Washington claim agents. Nothing but the President's veto could prevent "a grand scramble by a horde of hungry claim agents to get their hands upon vast unearned portions of the national treasure." 3 Other papers, like the $W$ ashington Post, defended the bill as an act of justice and said that the cost of carrying out its provisions had been grossly exaggerated. ${ }^{4}$ Disregarding the opposition, President Hayes made the Arrears Act law by his signature on January $25,1879 .^{5}$

${ }^{1}$ Cong. Record, 45th Cong., 3d Sess., Part 1, 484-494.

2 New York Herald, January 22, 1879, p. 4, col. 2; also New York Tribune, January 22, 1879, p. 1, col. 1 . Another discussion of the arrears bill in cabinet meeting is reported in the New York Tribune, January 25, 1879, p. 1, col. 2. John Sherman and others were opposed to the bill, but the majority of the cabinet favored it.

${ }^{3}$ See New York Tribune, Jan. 20, 1879, p. 5, col. 5; also Jan. 21, 1879, p. 1 , col. 3 .

4 See Washington Post, Jan. 21, 23, 24, 27, 28, 1879.

5 This act of President Hayes was the subject of much condemnatory criticism then and thereafter. A specimen is from the Springfield Union (Rep.): "In deciding not to resist this pension raid upon the Treasury, 
As approved by the President, the new law provided that all pensions which had been granted under the general laws regulating pensions, or which should thereafter be granted, in consequence of death from a cause which originated in the United States service during the Civil War, or in consequence of wounds, injuries, or disease received or contracted in the same service, should commence from the date of the death or discharge of the person on whose account the pension had been, or should thereafter be, granted, or from the termination of the right of the party having prior title to the pension. The fact of greatest significance in the above provisions was that arrears were to be paid on all pensions which should thereafter be granted, with no limitation whatever on the date of presenting the claim. This would make the prospect of obtaining a large sum of arrears a constant stimulus to the presentation of new claims. The amount at stake would increase with every passing year from the time of the soldier's discharge. Several earlier proposals for the payment of arrears had contemplated the fixing of a final date of limitation for the presentation of claims which should, if allowed, entitle a pensioner to arrears.

In its provision as to the rate of pension, the Arrears Act was vague and difficult to interpret. It said that the rate for the intervening time for which arrears were allowed was to be the same per month as that for which the pension was originally granted. Apparently this required that a pension originally: granted under the higher rates prevailing in 1879 should receive

President Hayes shows even more than his usual weakness, and makes people sigh more deeply than ever for a return of Grant." (Quoted in New York Tribune, January 28,1879 , p. 5, col. 1.) That Mr. Hayes felt such criticism is shown in a letter he wrote to William Henry Smith, December 14, 1881; from which the following excerpt is made: "The thing I would talk of, if I ever defended or denied or explained, is the Arrears of Pensions act. That act was required by good faith . . The pensions were due from the date of disability, if discharged on account of it, and from the date of such discharge. . The failure of government to protect itself against frauds is no reason for evading just obligations. The amount is small compared with other war expenditure and debt. . . Look at the good done. In every county in the North are humble but comfortable homes built by the soldier out of his arrearage pay." C. R. Williams, Life of Rutherford Burchard Hayes, ii, 338 (New York, 1914). 
arrearage at such rate for the intervening years since the soldier's discharge from the army. Perhaps the soldier pensioned in 1879 was not actually disabled for supporting himself during much of the intervening period. Yet he would receive more pension money than the soldier who proved a pensionable disability in the years soon after the war and was originally pensioned at the comparatively low rates then prevailing.

Not only were arrears to be paid to the pensioners actually entitled thereto, but, if a pensioner entitled should have died, the act provided that the Commissioner of Pensions should adopt rules and regulations for the payment of the arrears to the person or persons entitled to the same. This involved the distribution of large amounts of arrears in the families of deceased pensioners.

The Arrears Act also repealed a provision of the pension law placing a limitation on the use of parole evidence in establishing claims. Previously, if a claim had not been prosecuted to a successful issue within five years from the filing of the application, it could not thereafter be established by parole evidence. It failed unless it could be established by evidence drawn from the records of the War or Navy Department. The change opened the way for the renewal of many long standing claims of a doubtful character, and the prospect of arrears operated as a powerful incentive to the finding of necessary parole evidence to complete such claims.

There was also a section in the Arrears Act which forbade claim agents to receive compensation for services in making application for arrears. Mr. Cummings, sponsor for the measure in the House of Representatives, testified (see footnote, page 159 ) that he had this amendment inserted in the measure to meet the charge that it was a "lobby bill." Superficially, this provision may seem to have deprived claim agents of all pecuniary interest in the passage of the bill. Nothing could be farther from the truth. The amendment served, in fact, as a cunning blind, and gave to the bill the appearance of being wholly for the benefit of the soldiers and their dependent relatives. In the arrears law the 
great point of importance was not that it granted millions of arrears on clains already allowed, but that it offered arrears dating from the time of death or discharge to all future applicants who should succeed in establishing original Civil War claims. Here was a premium, often one thousand dollars or more, placed on the establishment of new claims, with the amount of arrears in prospect accumulating year by year. Claim attorneys needed no unusual keenness of mind to perceive that, in all probability, this extraordinary stimulus would enable them to bring upon the Pension Bureau a flood of original claims from all parts of the country. Upon such claims they were at that time legally entitled to collect a fee not greater than ten dollars, without taking into consideration such sums as they might obtain by their common evasions and violations of the law. ${ }^{2}$ This whole aspect of the Arrears Act was utterly ignored in Congress. ${ }^{2}$

Although the signature of President Hayes had placed the Arrears Act on the statute book, there was delay in carrying it into operation. The prevalent tone of criticism was adverse in the

${ }^{1}$ An account has already been given of the attempt of Captain Dimmick and his associate lobbyists to raise a testimonial fund for themselves by means of subscriptions collected from the beneficiaries of the Arrears Act. The plan was to allow a number of claim agents a percentage of commission on all such subscriptions they obtained from their clients. This particular scheme was exposed before it produced great results.

The Arrears Act gave a remarkable impetus to the filing of new claims. The total number of original Civil War claims presented in 1877 was 22,169 ; in $1878,25,904$; in $1879,47,416$; in $1880,138,195$. On these new claims, the pension attorneys were legally entitled to collect fees. In 1880 it was estimated by a competent witness that about six-sevenths of the business before the Pension Bureau was in the hands of less than a hundred attorneys. What systematic and aggressive methods could do in the way of building up a large and profitable pension claim business under the Arrears Act and the general pension law, is shown by a statement made by Commissioner of Pensions Bentley to a committee of the House of Representatives on June 12, 1880. He said: "If Messrs. Fitzgerald and Lemon have made correct statements or estimates as to the number of claims which they represent [Lemon, about 30,000; Fitzgerald, about 25,000], the attorneys who represent one-half of all pending claims on the files of the Pension Office can be counted upon the figures [sic] of my two hands. That is to say, ten attorneys or firms may be named who represent among them considerably more than one hundred thousand claims. These accumulations of claims make a great and very profitable business to these gentlemen under the present system." House Reports, 46th Cong., 3d Sess., Report No. 387, 189 and 368.

2 The text of the Arrears Act is found in U.S. Statutes at Large, $\mathrm{xx}, 265$. 
press of both parties. It was even suggested that the whole scheme would be allowed to fail for want of an appropriation by Congress. Even the National Tribune, the organ of the Lemon pension agency, said in its February issue: "It begins to look very much as if Congress intended to back down and fail to appropriate at all. They seem frightened by the magnitude of their own previous action, and alarmed by the results of the measure so unanimously passed." Besides the problem of providing the necessary funds, the loosely drawn act opened up difficult questions of interpretation. The Pension Bureau held up all cases affected by the act, pending further action by Congress. ${ }^{1}$

On February 4, 1879, the Commissioner of Pensions estimated that $\$ 34,000,000$ would be required to pay the arrears on claims which had been allowed prior to January 25,$1879 ; \$ 2,500,000$ for arrears upon claims allowed and to be allowed between January 25 and June 30,1879 ; and $\$ 5,000,000$ to pay arrears upon claims which would be allowed in the fiscal year ending June 30 , 1880. In making his report and estimate, Commissioner Bentley called the attention of Congress to some of the manifest defects of the law and recommended changes and explanatory provisions. If his recommendations should be adopted, he thought the arrears on claims allowed prior to January 25,1879 , could be reduced to $\$ 25,000,000$, and that the amount of arrears to be paid on claims allowed after that date would be materially lessened.

The Commissioner also called the attention of Congress to the extraordinary facilities for the successful prosecution of fraudulent and unmeritorious claims afforded by the existing ex parte system of evidence. He said:

1 See the New York Tribune, February 3, 1879, p. 1, col. 2, and also the National Tribune (Washington), Feb., 1879, pp. 12 and 13. The National Tribume said that no funds were available to pay the arrears and mentioned a proposition to issue bonds to raise the money. It gave its support to a plan to issue $\$ 50,000,000$ of legal tender notes, "which will not cost the Government anything." It said that this was "undoubtedly the right thing to do," but that the money power of the great cities would be against it. At this time the Greenback party had a large following in the country, having polled more than $1,000,000$ votes at the congressional elections in 1878. 
As the law stood previous to the passage of the arrears act the temptation to fraud was very great, but since that act it is many times increased. Then the claims were comparatively few in which any considerable sum of money would be the immediate reward of a successfully prosecuted claim, but since that act every invalid claim allowed, as well as many of the other classes, will have in it from several hundred to several thousand dollars due the claimant at the first payment.

It is estimated by those best informed that there have been not less than $\$ 2,000,000$ paid out annually for fraudulent pensions. In my judgment, the estimate is below, rather than above, the actual amount.

With the temptation to the commission of fraud so greatly increased, and the road to the Treasury easy through $e x$ parte proceedings, the consequences can easily be foretold. Not only will the people be taxed to pay an annual tribute to the unworthy amounting to several millions of dollars; but with so many claims pending, and still to be presented, and the avenues to the two or three hundred persons, more or less, who are charged with their adjustment, open for the approach of interested parties, it will be little less than a miracle if extensive official corruption does not follow.

Mr. Bentley urged that Congress should provide for the adoption of the new plan for hearing and settling pension claims which he had recommended in his three preceding annual reports. This plan proposed to bring claimants and their witnesses face to face with officers of the government, by dividing the country into districts, and assigning one learned surgeon and one competent legal clerk to each district, who should go from place to place in the district and collect the testimony offered in support of the claims. ${ }^{1}$

In a letter to the Ways and Means Committee of the House, dated February 12, 1879, Secretary of the Treasury John Sherman accepted the statement of the Commissioner of Pensions that

${ }^{1}$ House Ex. Doc., 45th Cong., 3d Sess. (1878-79), Doc. No. 75. Commissioner Bentley's earnest efforts to reform the system of settling pension claims brought upon him the savage attacks of the group of Washington claim agents. When his plan came before the Senate, they "swarmed the capitol" in opposition. New York Tribune, Feb. 28 and March 1, 1879. Also see files of National Tribune (Washington) for 1878 and 1879, especially May, 1878. 
the Arrears Act as it then stood would require the payment of $\$ 41,500,000$ on claims allowed up to June 30,1880 . He estimated that, if this expenditure were made, there would be a Treasury deficit for the fiscal year 1880 of over $\$ 27,000,000$. His recommendation was that authority be given to raise the amount necessary by the sale of four per cent bonds. ${ }^{1}$

Later in the same session of Congress at which the Arrears Act was passed, a bill making appropriations for arrears passed the House after brief consideration and came to the Senate. ${ }^{2}$ In the Senate, the bill and proposed amendments, including some of Commissioner Bentley's suggestions, were the occasion of extended discussion. ${ }^{3}$ Several very important amendments were adopted by the Senate and accepted by the House. However, Mr. Bentley's plan to change the method of examining and settling pension claims was voted down.

It is interesting to find that, in the month or more tilat had elapsed since the Arrears Act became law, the Senate had awakened to some conception of the great prospective cost of the measure. It was freely alleged that Senator Ingalls and the other advocates of the arrears bill had given the impression that the amount to be taken out of the treasury could not exceed $\$ 20,000,000$ at the outside. Senator Thurman of Ohio said:

When that arrears of pension bill was under consideration, if my ears did not deceive me, the chairman of the committee read a communication from the Commissioner of Pensions, about a year old I think it was, in answer to a question put by some Senator here how much that would take out of the Treasury; and that statement, if I heard it aright, was that it would take about $\$ 18,000,000$. It certainly was so understood all around me, and the Senator from Kansas ex gratia, I think, said it might be $\$ 20,000,000$; he was disposed to put it at twenty millions. The very next

1 House Ex. Doc., 45th Cong., 3d Sess., Doc. No. 85.

${ }^{2}$ Cong. Record, 45th Cong., 3d Sess., Part 2, 1487-1488.

3 For the debate in the Senate see ibid., Part 3, 1980, 1981-1984, 2033-2040, 2042-2051, 2052-2058, 2223-2243.

4Cong. Record, 45th Cong., 3d Sess., Part 3, 2037. 
thing after the passage of the bill that I heard was that the Commissioner of Pensions required $\$ 4,000,000$ for the present niscal year, and thirty-odd million dollars for the next fiscal year, and there is no telling where it is to end ; and we are told in some quarters that it will take fifty, some say sixty, and some say one hundred millions out of the Treasury. I must say that, if that is so, there was a grievous error somewhere, a grievous mistake somewhere when the arrears of pensions bill was considered.

Senators Conkling and Ingalls engaged in a sharp discussion as to what the latter had said to the Senate at the time of the passage of the Arrears Act. Conkling had the better of the argument, for, if Ingalls had possessed any knowledge of the prospective cost of the measure, he had singularly failed to enlighten the Senate. In view of what actually happened, one of $\mathrm{Mr}$. Ingalls's replies to Conkling deserves quoting : ${ }^{1}$

Mr. Conkling. Will the Senator allow me once more to ask, because I am stupid, I confess I do not yet understand him, did the Senator mean that $\$ 19,000,000$ would be the cost of the arrears of pension bill, or did he mean that it would cost up to that date, to wit: January, 1879, $\$ 19,000,000$ and leave an indefinite cost afterward?

Mr. Ingalls. That was what I said, and of course it was what I meant, because the arrears of pension bill provided for the removal of the limitation, and what would be required of [for] those who thereafter made application could no more be calculated or estimated than one could calculate the number of birds that will fly through the air next year.

If $\mathrm{Mr}$. Ingalls had made a statement similar to this when the bill was on its passage, he would not be open to the suspicion that he was not straightforward with the Senate.

During the debate the Senate had under discussion the problem of providing funds to pay the arrears immediately needed. ${ }^{2}$ On February 28, 1879, Mr. Morrill of Vermont, for the Committee

1 Cong. Record, 45th Cong., 3d Sess., Part 3, 2050.

2 Ibid., Part 3, 2046-2047. 
on Finance, offered an amendment to authorize the sale of not exceeding $\$ 18,000,000$ of four per cent bonds to pay arrears. This proposal met objections on the part of Senator Voorhees of Indiana, who advocated as a substitute an amendment to reissue $\$ 18,000,000$ of legal tender notes for the same purpose. By this time Secretary Sherman had somewhat reduced his estimate as to the size of the prospective deficit. However, the Senate voted against either the sale of bonds or the reissue of legal tender notes.

While the arrears appropriation bill was being considered, there was a striking illustration of the manner in which expensive pension measures slip through Congress. The fact that Senators were deploring their ill considered action on the original arrears bill did not prevent them from adding to the appropriation bill an innocent little "rider" providing: "That the law granting pensions to the soldiers and their widows of the War of 1812, approved March 9, 1878, is hereby made applicable in all its provisions to the soldiers and sailors who served in the War with Mexico of 1846." There was no discussion of the significance of this amendment, and it was in the arrears appropriation bill when the measure passed. A motion to reconsider was entered by Senator Windom. Some days later, when he pointed out that "the little proposition so good-naturedly introduced by the Senator from Missouri [Mr. Shields] and so good-naturedly supported by a majority of the Senate the other evening would take from thirty to forty millions out of the Treasury," the vote by which the bill passed was reconsidered. The amendment was struck out after a debate in which the old question of loyalty and disloyalty during the Civil War came up, and considerable partisan and sectional acrimony was shown. The principal argument made against the provision for the Mexican War survivors was that it was so drawn as to permit a pension to be paid to Jefferson Davis. Several Northern Senators were unsparing in their denunciation of Mr. Davis, while Southern Senators came warmly to his defense. Perhaps some of the Senators who had voted for the expensive Mexican War "rider" were glad to find 
an excuse for changing their votes that was both convenient and politically profitable.

After the Senate had again passed the bill, it was sent to the House whose concurrence was obtained in Senate amendments of great importance. As finally approved by the President on March 3, 18 $; 9,{ }^{1}$ the law carried an appropriation of $\$ 25,000,000$ for the arrears due on claims in which the pensions were allowed prior to January 25, 1879. An extra appropriation of $\$ 1,800.000$ was made for army and navy pensions for the fiscal year ending June 30,1879 . While this was not specifically devoted to arrears payments, it was doubtless intended to be used in paying arrears on claims allowed between January 25 and June 30 . No appropriation was provided to pay arrears on claims to be allowed during the fiscal year $1880 .^{2}$

The appropriation bill, as amended by the Senate, greatly limited the operation of the original Arrears Act. It provided that the rate, at which the arrears of invalid-pensions should be allowed and computed, should be graded according to the degree of the pensioner's disability from time to time and the provisions of pension law in force over the period for which arrears were granted. In no case were arrears to be allowed and paid from a time prior to the date of actual disability. Pensions were to commence from the date of discharge "if the disability occurred prior to discharge, and if such disability occurred after the dis-

\footnotetext{
${ }^{1} U$. S. Statutes at Large, $\mathrm{xx}, 469$.

2 After the plans to provide the money for the payment of arrears had been voted down, the Secretary of the Treasury was left to find the funds in the best way he could. Secretary Sherman was interviewed on the subject by the New York Tribune. He said among other things: "This bill was not demanded by the pensioners, but by the claim agents, and will work great inequality. Those whose disability was not developed for years after the war will get as much as those who suffered daily from wounds and sickness . . The truth is that both Congress and the country have found out that our public debt will be temporarily increased by the large payments required under the recent Pension Act, and the better way is to acknowledge the fact and borrow the money on the best terms possible." New York Tribune, March 10,1879, p. 1, col. 4. As a matter of fact it did not prove necessary to sell bonds. The country was on the eve of many years of great treasury surpluses. Contrary to Secretary Sherman's estimates. customs receipts increased nearly fifty million dollars in the fiscal year 1880 as compared with the fiscal year 1879 .
} 
charge then from the date of actual disability." These modifications did away with some of the worst inequalities and abuses possible under the terms of the original Arrears Act.

An even more important change was the adoption of a limitation upon the time of filing claims under the Arrears Act. Congress now provided that arrears of pension should be paid only when the application for the pension had been filed, or should thereafter be filed, with the Commissioner of Pensions prior to July 1, 1880. Otherwise the pension was to commence from the date of filing the application. This limitation did not apply to claims by, or in behalf of, insane persons and children under sixteen years of age.

The establishment of such a limitation was not in harmony with one of the leading arguments that had been advanced by advocates of the Arrears Act. They had urged that the interposition of any statute of limitation against the full satisfaction of the claims of the ex-soldiers was a despicable defense on the part of the national government. They sought to place the government in the position of a debtor avoiding a just settlement with creditors holding claims of a most sacred nature. Nevertheless, it was the introduction of the limitation that saved the Arrears Act from being utterly unendurable. Expensive and harmful as the amended measure was, there was a prospect of some end to the drains upon the treasury. With the act left in its original form, the premium upon the successful prosecution of a pension claim would have grown greater with the lapse of each year. Now fifty years after the Civil War, a very few original invalid claims are still being allowed for services in that conflict. If all the claims of this nature presented since July $I$, $I 880$, had carried arrears as originally provided by the act of January 25, 1879, who could measure the inducement to fraud or count the cost? It was well that Congress provided some bar against the enormous demands that were impending on the treasury.

Besides the work of settling the arrears on claims already allowed or in process of adjudication, the Arrears Act brought 
a tremendous pressure of new applications upon the Pension Office. In his annual report for 1879, the Commissioner of Pensions said:

Since the act of January 25,1879 , commonly known as the Arrears Act, the new claims of invalids, widows, minor children and dependent relatives have come in at an unprecedented rate, the invalids at a rate more than double that ever before known in the history of the office, except in the year 1866, and within a few hundred of double the rate of that year, which, it will be noted, was the year following the disbandment of the armies, when all the sick and disabled soldiers became at once entitled to apply for pension, while the rate of the receipt of widows', children's, and dependent relatives' claims is greater than that of any year since 1867, and more than twice the rate of any year since $1871 .^{1}$

This was the claim agents' harvest time. Through their newspaper publications and otherwise, they made every effort to secure new applications. The business was conducted with feverish activity during the fiscal year 1880 in order that applications might be filed before the limitation went into effect on July 1. In May, 1879 , the National Tribune informed its readers that the Commissioner of Pensions had after long delay commenced to pay the arrears. ${ }^{2}$ In later numbers it published columns of letters from pensioners who had received attractive amounts of arrears through the Lemon pension agency. Warnings were also published that claims must be filed before the date of the limitation. Other pension attorneys and publications were doubtless no less active. The result of this wide advertising of the provisions of the Arrears Act and solicitation of claims was that during the fiscal year 1880 the total number of original claims filed for invalids, widows and dependent relatives on account of service in the Civil War was 138,195 . This was a

\footnotetext{
${ }^{1}$ House Ex. Doc., 46th Cong., 2d Sess., Report of the Secretary of the Interior, ii, 282.

2 National Tribune (Washington), May, 1879, and other issues of 1879 and 1880 .
} 
larger number than had been filed in the whole of the five year period from 1875 to 1879 inclusive, although the Arrears Act had been in force during the last five months of the fiscal year 1879. In the single month of June, 1880, just before the limitation upon the allowance of arrears went into effect, there were 44,532 original Civil War claims filed-more than twice as many as had been filed in the whole fiscal year 1877. In 1880 the total disbursements for pensions were $\$ 57,240,000$ as compared with $\$ 26,844,000$ in 1878 , the year before the Arrears Act was passed. ${ }^{1}$

The experience of the years 1881 and 1882 showed that the arrears on claims allowed prior to January 25, 1879, would reach nearly $\$ 25,000,000$, as estimated by Commissioner Bentley. It also became clear that the great cost of the measure would result from the feature entirely ignored upon its original passage, that is, the granting of arrears upon each claim allowed after January 25, 1879 (provided, by the amendment of March 3, 1879, that such claims were filed before July 1, 1880). If applications were originally presented within the prescribed time, delay in the completion of proof simply increased the allowance in prospect at the first payment. The average first payment in 1881 to an army invalid was $\$ 953.62$; to army widows, minor children and dependent relatives, $\$ 1,021.51$; to navy invalids, $\$ 771.42$; to navy widows, minor children and dependent relatives, $\$ 790.22 .^{2}$ While these were considerable sums, the amounts to be obtained by completing the proof in claims still pending steadily grew larger as the years passed by. There was every incentive to fraud, both in the prize to be obtained and in the weakness of the adjudicating system as a protection to the government against imposition. Commissioner Bentley had pointed this out in his report for 1879 when he said:

Besides being cumbersome and expensive, the present system is an open door to the Treasury for the perpetration

\footnotetext{
${ }^{1}$ The statistics are compiled from the annual reports of the Commissioner of Pensions.

${ }^{2}$ Report of the Commissioner of Pensions for 1881.
} 
of fraud. The afficlavits in support of the claims have the same appearance to the officers of the Bureau, whether true or false. . . . There is another aspect of the ex parte system which should receive the most earnest consideration on the part of the Government, and that is its fruitfulness of crime against the laws, in the nature of perjury, forgery and false personation.

On January 20, 1881, the Commissioner wrote to Senator H. G. Davis that, considering the whole case, he was of opinion that not less than ten per cent of the pension appropriations were paid out upon fraudulent and illegal claims. In 1881 that would amount to over $\$ 5,000,000$.

No one can tell what the total cost of the Arrears Act was. Even with the clause limiting its application to claims presented before July 1, 1880, Commissioner Bentley estimated, in the letter to Senator Davis above referred to, that the measure would ultimately cost $\$ 510,000,0000^{1}$ Besides the great total which the arrears payments reached annually, the ordinary payments for an indefinite series of years were very largely increased over what they would otherwise have been. If it had not been for the stimulus given by the Arrears Act, many pensioners might never have filed clains. Probably, in a larger number of cases, the presentation of the claims was hastened by many years. Normally the claims would have been presented later in life, and, if allowed, would not have carried arrears dating back to death or discharge. It is not possible to estimate accurately the number of claims which would have been filed if the Arrears Act had not been passed. But we have seen what a vast increase of applications over previous years immediately followed the passage of the measure. Certainly it was respon-

${ }^{1}$ Commissioner Bentley thought that the Arrears Act would cause 125,000 new pensioners to be placed on the pension roll in excess of those who would have been placed there if the act had not been passed. He estimated the average duration of these new pensions at twenty-two years. Therefore he included in his estimate of the total cost of the act an item of $\$ 284,000,000$ to cover the annual pensions to the 125,000 new pensioners. Of course there is much room for difference of opinion as to the correctness of such an item. House Reports, 46th Cong., 3d Sess., Report No. 387, 571-572. 
sible for a lasting increase in the ordinary burden of pension expenditures as well as for the disbursements for arrears. The arrears part of the expenditure had up to June 30, 1885, according to a statement of General J. C. Black, Commissioner of Pensions, reached $\$ 179,400,000$. While from the nature of the problem the exact cost of the Arrears Act can never be ascertained, the evidence clearly shows that it was several hundred millions of dollars. Since the act was passed under the assumption that it would take about twenty millions from the Treasury, its critics did not speak too strongly when they denounced it as an outrageous swindle.

The great body of the old soldiers did not ask for this measure and were not responsible for it. In a long and acrimonious debate in the Senate in 1882 much light was thrown on the subject. $^{1}$ In the course of the discussion, General Hawley of Connecticut, a high minded representative of the Civil War veterans, said :

I believe that the mass of the soldiers did not ask for this act; they did not expect it; they were as much surprised by it as anybody; they did not enlist with a chief view to the awards in money; nor would they unduly burden the country they offered their lives to save.

Could the true sentiments of the soldiers themselves have governed legislation on this subject, I believe it would certainly have been just, liberal, even generous, but it would have been shown rather in large pensions for the future than in the gift of large sums in gross for the past, and it

\footnotetext{
1 Senator Beck of Kentucky had said: "I would promptly repeal the arrears of pension act. It was conceived in sin and brought forth in iniquity. It is a fraud upon the American people, and a standing monument to the ignorance, selfishness and cowardice of the American Congress." Senator Ingalls felt called upon to reply and offered a resolution, "That in the opinion of the Senate the act of January 25,1879 , commonly known as the arrears of pension act, ought not to be repealed." A long, and at times bitter, debate followed, which was continued from time to time. Various amendments to the Ingalls resolution were proposed, and in the end it was ordered to lie on the table. The resolution was introduced January 12, 1882, and the debate began on January 16. See Congressional Record, 47th Cong., 1st Sess., Parts 1 and 2. Senator Hawley's speech on February 6 is reported in Part 1 , p. 921, and is worth reading in full.
} 
would have been accompanied by the most careful provisions for thorough investigation and just award.

However, General Hawley maintained that the Arrears Act was on the statute books, and that those who applied during the prescribed period of time acquired a moral and equitable right to receive the payments.

The great money cost of the Arrears Act was easily met by the abundant national revenues of the period from 1880 to 1890 . After the first year of the law, there was no more talk of having to sell bonds. But there were other serious consequences of the measure. The great volume of new business caused the group of Washington pension attorneys to grow prosperous and powerful. By constant advertising and drumming, a few of the most active attorneys succeeded in concentrating in their offices the prosecution of a great majority of outstanding claims. Some attorneys had cases by the tens of thousands pending and were eager to secure early and favorable action in order that they might collect a fee of at least ten dollars in each successful case. When Commissioner of Pensions Bentley proceeded with caution and deliberation in the settlement of claims and established regulations to safeguard the interests of the government, the group of attorneys started a general attack on his administration of the office and circulated among the former soldiers petitions for his removal. ${ }^{1}$ All through 1878 and 1879, the National Tribune (the organ of George E. Lemon, the leading pension attorney) was devoting its columns to a systematic campaign against Mr. Bentley and his plans for reform in pension administration. The December, 1879, issue especially invited the Grand Army of the Republic to scrutinize the Pension Office. On January 12, 1880, the House of Representatives voted for a committee investigation of the Pension Office. ${ }^{2}$ The fact that a presidential campaign was approaching may have had something

\footnotetext{
${ }^{1}$ New York Tribune, May 3, 1880, p. 1, col. 4.

${ }^{2}$ The record of this investigation is to be found in House Reports, 46th Cong., 3d Sess., No. 387.
} 
to do with the willingness of the Democratic House of Representatives to investigate Mr. Bentley, a Republican. The investigating committee was headed by Mr. Coffroth of Pennsylvania, who, the Neze York Tribune said, was an attorney interested in pension claims. ${ }^{1}$ Hearings were held from time to time during the first half of 1880 and were later continued during January and February, 1881.

Much of the testimony was that of attorneys who charged Commissioner Bentley with arbitrary rulings and unnecessary delays in the adjudication of pension claims. The Commissioner replied that the Pension Office had been overwhelmed with applications since the passage of the Arrears Act, that the clerical force was insufficient to keep up with the volume of business, and that insistence on rules and regulations was necessary in order to guard against fraud under the unsatisfactory ex parte method of taking testimony. Mr. Bentley attacked the "machine" methods of the leading claim agents who had solicited applications from far and near, and to a very large extent concentrated in a few offices the business of prosecuting pension claims. He pointed out that pension attorneys who represented tens of thousands of applicants had no personal acquaintance with their clients and gave themselves little concern as to the character of the affidavits they gathered and presented. The Commissioner considered that much of such evidence was not trustworthy, and delays were frequently necessary for careful inquiry into the merits of cases of this class.

The charge was also made that the conduct of the Pension Office was influenced by political motives. One former claim agent alleged that Commissioner Bentley had been delaying the allowance of claims in compliance with the wishes of Secretary of the Treasury Sherman, who would be unable to present a

${ }_{1}$ New York Tribune, November 10, 1880, p. 1, col. 5. The Tribune had said on June 23,1880 (p. 5, col. 1), that two objects were in view in having the House committee investigate the Pension Office: "One was to hunt up something in the interest of the claim agents by which to delay and obstruct the work of reorganizing the pension system. The other was to gather material for use in the coming campaign to show that under a Republican administration the pensioners have not been properly and fairly attended to. In both respects the investigation has thus far been a failure." 
good financial report in the year of the presidential campaign if so many millions were turned out of the Treasury. The implication was that a poor Treasury report for 1880 would be damaging politically to Secretary Sherman and the administration. ${ }^{1}$

When the committee investigation was continued during the winter after the presidential election, the fact was established that in October, 1880, the Pension Bureau allowed 4,423 original claims-far more than in any other month of the year. A charge was made that attention was concentrated on Ohio and Indiana cases in order to gain votes in those states by the granting of pensions. There was also testimony that favorites in the Bureau were given cases to investigate at election time in the vicinity of their homes and that they were thus able to participate in elections and have their traveling expenses to and from their homes paid by the government. However, even if the truth of such charges be granted, the political activities of the Pension Bureau in the campaign of 1880 were slight as compared with its conduct in later presidential campaigns. ${ }^{2}$

In its final report, the investigating committee said that the responsibility for administering the law fairly was on the Commissioner of Pensions and that the successful management of the Bureau would depend on the personality of the chief. It found that there had been delays in deciding cases promptly after all the necessary evidence had been filed. The committee advocated the creation of a court of pensions, or a board of appeals and review (not subject to the Commissioner), to review the decisions of the Commissioner in rejected cases. Otherwise no changes in the law were recommended. However, the report asked that the committee be continued as one of the permanent committees of the House. ${ }^{3}$

Commissioner Bentley had displayed both ability and courage

1 Testimony of George M. Van Buren, April 3, 1880. House Reports, 46th Cong., $3 \mathrm{~d}$ Sess., No. 387, 89-90.

2 For testimony regarding the above political activities, see ibid., 385, 388-389, 424.

3 The brief final report is prefixed to the lengthy testimony. The proposal for a Pension Court was before the 46th Congress in a bill which failed of passage. 
in his constant efforts to improve the administration of the Pension Bureau and to protect the government against fraud. But his bitter opponents, the Washington claim agents, succeeded in making him unpopular with the former soldiers, and, on June 27, 1881, President Garfield commissioned Colonel W. W. Dudley of Indiana in his stead.

The Grand Army of the Republic met that year at Indianapolis and for the first time actively intervened in the matter of pensions by appointing a committee to look into the delay in the settlement of pension claims and report recommendations. ${ }^{1}$ This committee was able to report at the annual encampment in 1882 that "the accredited representatives of our order have come directly in contact with the law making power. Common justice demands that we should officially state the obligations we feel under for the cordial reception we met with at the hands of the Pension Committees of both Houses." The committee had every reason to be gratified at its success with Congress. Among the important results of the committee's work, as reported by Corporal James Tanner, was the authorization of the employment of about twelve hundred additional clerks to be employed in various offices to expedite pension work at an annual expense of $\$ 1,742,430$. The committee recommended that the Grand Army should establish a standing committee on pensions. ${ }^{2}$ With Commissioner Dudley in the Pension Bureau, and a largely increased clerical force, claimants had high hopes that allowances would proceed more rapidly and largely increased sums of money be paid out.

On December 8, 1882, the Senate passed a resolution calling upon the Pension Bureau for information upon several matters, including the cost of carrying out the Arrears Act and the probable cost of certain proposed legislation. ${ }^{3}$ Senator Beck of Kentucky succeeded in amending the resolution to provide for the

1 Journal of the I5th National Encampment, G. A. R., 791.

2 Journal of the 16th National Encampment, G. A. R., 872-875. At this encampment, the commander-in-chief cautioned the posts against partisan political activity, which was against the rules of the order. Ibid., 868-869.

${ }^{3}$ Congressional Record, 47th Cong., 2d Sess., Part 1, 35, 71, 103. 
publication of the pension list. From Commissioner Dudley's reply, dated December 16, 1882, it appears that on December 1 the number of pensioners on the roll was estimated at 291,656, with pensions having an annual value of $\$ 30,013,000$. There were about 275,000 original Civil War applications pending, and 79,583 claims on the rejected files which might be reopened on the discovery of material new evidence. The Commissioner reported that the total disbursements for arrears from January 25, 1879 , to December 1,1882 , were $\$ 97,892,000$. He pointed out the difficulty of estimating the future cost of the Arrears Act. There remained on the files of the Pension Bureau 253,648 original Civil War claims which had been presented prior to the expiration of the limitation on July 1, 1880. Commissioner Dudley estimated that 202,919 of these might eventually be allowed. If they should all be allowed simultaneously, and if each claim should receive the average amount of arrears then being paid on claims of like nature, the additional amount of arrears to be paid would be $\$ 204,795,000$. And placing these new pensioners on the roll would increase the annual value of the pensions on the roll from $\$ 30,000,000$ to $\$ 50,000,000$. $^{1}$ Later, as required by Senator Beck's amendment, the whole pension list was published as of January 1, 1883. The report, in five volumes, gave the name of each pensioner, the cause for which pensioned, the post office address, the rate of pension per month, and the date of the original allowance. ${ }^{2}$

Upon the publication of Commissioner Dudley's estimates in reply to the resolution of the Senate, vigorous editorials in opposition to increased pension expenditures appeared generally in the newspapers of the large cities. When the pension list appeared later, there were further articles in criticism of persons found upon it. In reply, Mr. Lemon's National Tribune championed the cause of the pensioners and claimants. ${ }^{3}$ It urged

1 Senate Ex. Doc., 47th Cong., 2d Sess., No. 21.

I Ibid., No. 84.

${ }^{3}$ Under the heading "The Hue and Cry which the Newspaper Bloodhounds Are Raising against our ex-Soldiers," the National Tribune of January 4, 
editorially that the ex-soldiers must organize, that they must make up their minds "to vote against every candidate for political honors who is not pledged to their cause," and "to withdraw their patronage from every newspaper which is opposed to pensions." 1

In advising the ex-soldiers, the National Tribunc spoke with more than the authority of a claim agent's organ; it had received official recognition and endorsement from the G. A. R. Commander-in-Chief Paul Van Dervoort, who had been elected at the national encampment in 1882, had issued general orders on December 21, 1882, in which he named Mr. George E. Lemon as one of his aides-de-camp "on account of the valuable services rendered the Grand Army of the Republic by the National Tribune."2 Mr. Lemon's paper was exceedingly active during 1882 and 1883 in promoting the organization of Grand Army posts. In the annual address at the Denver National Encampment, July 25, 1883, Commander-in-Chief Van Dervoort praised Mr. Lemon and his publication and said that they had referred to the national headquarters applications for 170 new posts, nearly all of which had been organized. ${ }^{3}$

In the same address, the commander-in-chief said that the G. A. R. must be non-partisan. The National Tribune, at this time, agreed that the order must be non-partisan. However, it urged the ex-soldiers to go to the nominating conventions of both parties and demand recognition. At elections the veterans

1883, published editorials against pensions from the New York Sun, Cincinnati Commercial, Boston Herald, Chicago Tribune, Philadelphia Times, Boston Herald, Utica Observer, St. Louis Globe-Democrat, New York Tribune, Utica Herald, and Chicago Times. The National Tribune even went so far as to criticize the attitude of General Grant, who, in writing to recommend the passage of the bill increasing the pensions of those who had lost a limb, said: "I concur in recommending the passage of the above bill. No pension can compensate the men who have lost one or more limbs, and I should be glad to see that class of pensioners well provided for instead of the indiscriminate pensioners, many of whom are physically as good as they would have been if the war had never been fought." See National Tribune, January 4, 1883; January 25, 1883; March 1, 1883.

${ }^{1}$ National Tribune, editorial, January 11, 1883.

2 Ibid., January 4, 1883.

3 Ibid., July 26, 1883. 
were asked to support soldiers' candidates "pledged to their cause." In furtherance of this policy of extensive organization and acquisition of political influence, the National Tribune maintained a weekly Grand Army of the Republic department, devoting much space to all the activities of the order and diligently promoting its expansion.

Doubtless the promotion of their principal organization under such auspices had a great influence in changing the feeling of the old soldiers regarding pensions. As late as 1882, General Hawley said in a speech in the Senate to which reference has already been made : 1

There are no men who will pass a severer judgment upon excessive or unnecessary or fraudulent pensions than the soldiers themselves. The majority of them are not pensioners, and they hope that health, industry, and good fortune will prevent their ever becoming such. While they do feel and manifest a great-hearted sympathy for needy and suffering comrades, are generous in their own gifts, and consider liberality on the part of the government not charity but justice, they know also that among 2,000,000 of soldiers there is humanity's proportion of unworthy men who are the natural prey of the creatures that always fly from afar to the disbursement of great treasures.

Unjust, unnecessary, and excessive pensions are an injustice to the unpensioned soldiers, who are tax-payers, as considerate of excessive taxation and quite as fully anxious to see an economical, prudent, and just government as any other worthy and patriotic class of citizens.

The National Tribune and many lesser publications of its kind were continually teaching a very different doctrine. They said that the ex-soldiers had saved the Union and that the country owed everything it had to them, that the debt was greater than could ever be repaid, that the bondholders had received billions in principal and interest, and that those who had risked flesh and

1 February 6, 1882, Cong. Record, 47th Cong., 1st Sess., Part 1, 921. 
blood could never be pensioned too liberally. Ordinary safeguards in the administration of the pension laws were denounced on the ground that all doubts ought to be resolved in favor of the claimants. Honest and careful officials were hounded and vilified. The country was said to be rich and the treasury overflowing. Propositions to reduce federal taxation were opposed on the ground that the funds available for pensions would thereby be reduced. Threats of political opposition and defeat were made against legislators who did not yield to the extravagant demands made in behalf of the pensioners. And all the while the ex-soldiers were assured that they had honest claims in the nature of contracts against the government, and that any refusal to grant whatever demands happened to be made in their interest was a refusal by the government to pay its just obligations. This pension propaganda was carried on week after week and month after month in sheets that went into hundreds of thousands of homes throughout the land. ${ }^{1}$ And it was given a very real and convincing aspect by the substantial millions that were distributed throughout the northern and western states under the Arrears Act. No wonder that the appetite for pensions on the part of a large proportion of the ex-soldiers became eager and finally insatiable. If their country could never pay the debt it owed them, they were determined to collect all they could. Perhaps those who held the just and reasonable views of General Hawley were in the majority, but they did not control the soldier organizations. Their honorable protests against extravagance and fraud in the pension system were too often without avail in the face of

1 The National Tribune was the largest and most influential soldiers' paper, but there were many others of like character. The National Tribune contained much historical and literary matter interesting as family reading. On January 15, 1885, Mr. Lemon testified before a House Committee that it had 112,000 bona fide subscribers and went to between 18,000 and 19,000 post offices. He said that he sometimes sent out as many as 500,000 copies in one week. Some editions of this size had been sent out in the fall of 1884 . $\mathrm{Mr}$. Lemon said his method was to send out 200,000 or 250,000 sample copies, because it was cheaper to send out a large edition than to advertise in other papers for subscribers. It will readily be seen that the influence of such a paper was worth considering. House Reports, 48th Cong., 2d Sess., No. $2683,16,26,89$. 
the clamor of the organized claimants and the wiles of their attorneys. ${ }^{1}$

Beginning with the authorization at Indianapolis in 1881 of the committee to look into the delay in the settlement of pension claims, the G. A. R. was regularly represented at Washington during the sessions of Congress. At the Denver encampment in 1883, a resolution was passed authorizing the commander-in-chief to appoint annually a committee of five to be known as the Committee on Pensions. ${ }^{2}$ These men became the plenipotentiaries of the G. A. R. to the Congress of the United States. In the winter or spring they presented their program of desired legislation to the pension committees of the two Houses, and at the annual summer encampment they reported results to their comrades in the organization.

As 1884, the year of the presidential election, approached, many pension measures were introduced in Congress. These included a Mexican War pension bill, a proposal to pension soldiers of the Civil War who had disabilities not of service origin, and a bill to repeal the limitation in the Arrears Act. Senator Ingalls put forward the last proposal, and the National Tribune enthusiastically supported him. Pension claimants who had not filed their applications before July 1, 1880, felt it a hardship that they were deprived of arrears, while comrades who had applied shortly before the prescribed date might, upon the allowance of a claim, receive a thousand dollars or more at the first payment. To the pension attorneys the prospect of the payment from the treasury of unlimited amounts of arrears appealed strongly as a stimulus to keep up the volume of their fees and business. Sen-

${ }^{1}$ In an article "A Raid upon the Treasury," L. W. Bacon says: "One of the most pitiable results of the Arrears of Pensions Act was the demoralization of the ex-soldiers. . . . To a painful extent, the ex-soldiers throughout the nation were intoxicated by these copious drafts from the Treasury, and began to rave and threaten, like drunken men demanding more drink. Their organizations for mutual aid and good fellowship were turned into political machines not for the promotion of public ends, but for the one purpose of public plunder for the personal profit of the members. Candidates for office were pledged to the support of new projects of robbery, under the threat of being opposed by 'the soldier vote." Forum, vi, 545 .

2 Journal of the I7th National Encampment, G. A. R., 151-152. 
ator Ingalls said: "I do not care whether it costs one million or one thousand million; I am pushing this matter simply upon its abstract justice."'

Whether one advocated the repeal of the arrears limitation for reasons of political expediency or of abstract justice, there was no doubt that the Treasury was able to meet increased drafts upon it. John Sherman's predictions of an enlargement of the public debt because of the original Arrears Act had not come true. Despite the heavy increase in the pension expenditures, the surplus piled up year after year, the excess of net ordinary receipts over expenditures being $\$ 133,000,000$ in 1883 and $\$ 104$,000,000 in 1884. Among the many and varied proposals that were put forward for using this surplus, the pension projects were most attractive to many party leaders as giving promise of a popularity among the ex-soldiers and their friends that might be turned to political advantage. ${ }^{2}$

The representatives of the veterans took advantage of the favoring circumstances to press their measures before Congress. When the House of Representatives by an overwhelming ma'jority passed a Mexican War pension bill early in March, 1884,

1 Senator Ingalls introduced his new arrears measure, with the limitation as to the time of filing claims stricken out, as Senate bill, No. 1, for the 48th Congress. In a two column interview in the National Tribune for December 13, 1883, the Senator said that he had made a pledge to introduce the bill at the annual reunion of the G. A. R. at Leavenworth, Kansas, in October. He also said that two Republican state conventions, those of Ohio and Iowa, had endorsed the measure. The same issue of the National Tribune contains a long commendatory editorial on "Senator Ingalls and the Arrears Bill." In January and February, 1884, the National Tribune published a series of articles, over the signature of Senator Ingalls, asserting that the previous Arrears Act had been of "incalculable benefit" to the country, advocating the repeal of the limitation, and also explaining and supporting other pension measures. 'See National Tribune for December 13, 1883; January 31, 1884; and February 28, 1884.

2 Senator Ingalls wrote in the National Tribune, January 31, 1884: "The national credit has been sustained; the interest on the debt has been paid; all branches of the public service have been amply supported; and notwithstanding all these exactions, a superabundant revenue continues to inundate the Treasury. What better use can be made of our surplus than to pay to the utmost farthing these most sacred of all our national obligations?" Any alternative plan to dispose of the surplus by the reduction of federal taxation was vigorously opposed by the pension interests. See National Tribune, January 4, 1883 ; March 8, 1883 ; February 7, 1884; New York Sun, January 24,1884 . 
the National Tribune observed that "the real test of its [the House's] patriotism will come when the various measures conceived in the interest of the veterans of the late war are brought up for action." On March 6 the Committee on Pensions of the G. A. R. met in Washington to prepare a program of pension legislation to recommend to Congress. ${ }^{2}$ The chairman of the committee was Past Commander-in-Chief George S. Merrill, and the other members were Past Commander-in-Chief Louis Wagner, Past Commander-in-Chief Paul Van Dervoort, General C. H. Grosvenor, and Corporal James Tanner. There were then before the committees of Congress nearly one hundred distinct bills relating to the general subject of pensions. The committee had before it Commissioner of Pensions W. W. Dudley and Comrade George E. Lemon, and heard at length their views as to the legislation that ought to be enacted. Finally the committee selected about a dozen different pension proposals to present to Congress at that time. ${ }^{3}$

1 National Tribunc, March 6,1884. The bill passed by 227 yeas to 46 nays. 2 For an account of the meetings and proceedings of the committee, see the National Tribune, March 13, 1884. For the official report of the committee to the G. A. R., see Journal of the I8th National Encampment, 105.

${ }^{3}$ Committeeman Paul Van Dervoort was more extreme in his views of what should be advocated than his associates. He was in close relations with George E. Lemon. During this same year he was employed by Lemon as a clerk on the National Tribune. (Testimony of George E. Lemon, February 9, 1885, Housc Reports, 48th Cong., 2d Sess., Report No. 2683, 159-160.) In 1885 Lemon's methods in securing the passage in July, 1884, of a pension attorney's fee bill highly advantageous to himself were under investigation. It was thought that Van Dervoort had assisted him in the matter.

When Van Dervoort was commander-in-chief of the G. A. R. in 1882-1883, he had appointed Lemon one of his aides-de-camp and had singled him out for especial praise in his annual address at the national encampment in 1883 . In September, 1883 (after his term as commander-in-chief had expired), Van Dervoort was summarily removed from the office of chief clerk of the U. S. Railway Mail Service at Omaha, Neb., by order of Postmaster General Gresham. The charge was that the service in his section was demoralized and that he neglected his duty and absented himself from his post the greater portion of the time. "He has insisted that because of his connection with the G. A. R. he should be allowed to draw pay as chief clerk without performing the duties of the office. The National Tribune (September 13, 1883, and following) defended him in issue after issue and attempted to force his reinstatement. Van Dervoort claimed that what he had done was with the knowledge and consent of the Department. At the national encampment of the G. A. R. in 1884, Van Dervoort represented Lemon's views by attacking the administration of Commissioner of Pensions Dudley. 
Having agreed upon the measures to be supported, the G. A. R. men appeared before the pension committees of both Houses and interviewed individual Senators and Representatives. They put their views in the form of a memorial to Congress, favoring about a dozen different measures and specifically opposing a few extreme proposals. In the matter of arrears the committee was more moderate than Senator Ingalls, asking only that the arrears limitation be extended to January 1, 1885. The conmittee also favored giving pensions to disabled soldiers without compelling them to prove that their disability actually arose from service, and also to the widows of soldiers regardless of whether the husband died from causes of service origin. Among the other measures advocated were the increase of widows' pensions from eight to twelve dollars a month, an increase in the additional pension for minor children, and large increases for certain specific disabilities. The committee opposed the bills "proposing to grant pensions at the present time to all survivors of the war, regardless of whether they were wounded or became disabled in the service or are needy." On March 15, Commander-in-Chief Beath, in general orders, commended the action of the pension committee to all members of the G. A. R. and asked that they urge Senators and Representatives to adopt in bills the recommendations of the committee. ${ }^{1}$

A disposition to do something for the ex-soldiers was shown by the passage in the House of Representatives, under a suspen-

\footnotetext{
${ }^{1}$ On March 31, 1884, the G. A. R. reported 4,323 posts and 233,595 members. By June 30 gains in membership made the total 253,895. At the annual encampment at Minneapolis, July 23, 1884, Commander-in-Chief Beath in his address credited the National Tribune with assisting in organizing a large number of new posts. It was the only soldiers' paper especially mentioned. He cautioned posts against becoming associated with any political movement and suggested that it was in bad taste to wear the G. A. R. badge at any political meeting. He reprimanded a large number of posts which, instead of supporting the action of the committee on pensions, had petitioned for a law granting all survivors of the Civil War who served sixty days and were honorably discharged a pension of eight dollars a month. He charged these posts with responsibility for the failure of legislation to increase the pensions of widows and minor children. Journal of the I8th National Encampinent, G. A. R., 22, 34-38.
} 
sion of the rules, of the IVarner pension bill on April $21,1884{ }^{1}$ It had reference to the many thousands of claimants who were not able to supply record or other evidence sufficient to complete the legal proof that their disabilities were of service origin. The rules of evidence were relaxed in this bill for the benefit of those whose disabilities were "probably" of service origin. However, claimants who should apply under this act were not to be entitled to arrears. Commissioner Dudley wrote a letter favoring the measure as "a most important step in the right direction." His office was being made the target of adverse criticism because of the slowness in allowing clains. ${ }^{2}$ The reply had been made that the delay was due to the fact that claimants had not completed their evidence. There was prospect under the Warner bill that a large number of such claims could be allowed. But the bill was too limited in its scope to please extreme advocates of pensions. On April 24, the National Tribune denounced it as a sham and said that the G. A. R. committee had been disregarded.

As the time for the presidential nominating conventions approached, the National Tribune conducted an agitation for soldier candidates. It urged the soldiers to go to Chicago and see that their wishes were consulted by both political conventions. Candidates were desired "whose ficlelity to the soldier is beyond question." 3 The results of the Republican convention early in June were highly satisfactory to the National Tribunc both as to the "soldiers' ticket" named, Blaine and Logan, and as to the following pension plank in the platform. ${ }^{4}$

The grateful thanks of the American people are due to the Union soldiers and sailors of the late war, and the Republican party stands pledged to suitable pensions for all

1 The vote was 165 yeas to 57 nays. Cong. Record, 48th Cong., 1st Sess., Part 4, 3195-3199.

${ }^{2}$ See National Tribune, January 10, 17, and March 6, 1884.

3 See National Tribune, May 8, 1884. The issue of April 10 advocated John A. Logan as a suitable Republican nominee for the presidency.

4 See account of the Republican convention in National Tribune, June 12, 1884. John A. Logan was one of the first commanders-in-chief of the G. A. R. 
who were disabled and for the widows and orphans of those who died in the war. The Republican party also pledges itself to the repeal of the limitation contained in the arrears act of 1879 , so that all invalid soldiers shall share alike, and their pensions shall begin with the date of disability or discharge, not with the date of their application.

This pledge was what Senator Ingalls had proposed in his bill then pending in the Senate. The G. A. R. committee in March had asked only that the arrears limitation be extended to January 1, 1885. After the Republican convention, Senator Ingalls, on June 12, 1884, offered his arrears bill as an amendment to the Mexican War pension bill, which had passed the House and was then under discussion in the Senate. After referring to the censure he had undergone in connection with the Arrears Act of 1879 , he said :

I am very glad that at last the party to which I have the honor to belong has reached the platform upon which I was one of the first to stand, and has at last declared itself in unmistakable terms in favor of the extension of the principle recognized in the act of 1879 , without reference to the period of time when the application was made. The Republican party is distinctly pledged at this time, whenever the opportunity offers, to remove the unjust and invidious linitation in that act, which was when proposed a compromise, and I now call upon my party associates to vindicate that act and to carry out the express declaration and intention of the party in its late convention.

no Senator on this side of the Chamber can afford, at this period of the political history of this country, after one Presidential convention has been held and while another is shortly to be held, to be placed in a position of opposing legislation that is legitimately in favor of the soldiers of the late war for the Union.

In reply Senator Sherman said $:^{2}$

1 Cong. Record, 48th Cong., 1st Sess., Part 5, 5049-5050.

2 Ibid., 5050. However, in the Senate, January 27, 1887, Sherman said that he had been called to account by his constituents and had changed his views. Cong. Record, 49th Cong. 2d Sess., Part 2, 1070. 
With my present convictions, in view of the enormous demands made upon the Treasury, I would not vote and will not vote, if pressed, for the amendment moved by the Senator from hansas, and the quotation of a political platform will not change my views.

I do not think the principle is right. I think a pension ought to commence when the application is filed. That is the true principle, and I shall vote for that. If anybody is dissatisfied with it, I will try and reason with him and convince him that I am right, but if not, no difference.

Although the Ingalls amendment finally came to a vote in modified form, extending the arrears limitation only to October 1,1884 , it was defeated by yeas, 26, and nays, 39 . Sherman, Edmunds, Hawley, Morrill and a few other Republican Senators refused to be bound by the party platform to a support of even this compromise proposition. ${ }^{1}$ Naturally the Democrats were in the negative. The force of political exigencies is seen in the fact that so many Senators were found voting for a measure that would possibly cost the country a quarter of a billion dollars in additional arrears payments. ${ }^{2}$

After the arrears amendment to the pending Mexican War pension bill had been defeated, the Senate added as an amendment a Civil War pension bill which had originally been introduced by $\mathrm{Mr}$. Cullom. ${ }^{3}$ Besides increasing the pensions of widows and minor children, this amendment granted pensions to persons who served three months in the Civil War, and were dependent upon their own labor for support, for disabilities not of service origin. Such disabilities might not be the result of gross carelessness, disreputable conduct or vicious habits. Such an extension of the Civil War pension system was incomparably more important than the original Mexican War pension bill. In general character, it anticipated the Dependent Pension Bill which President Cleveland vetoed in 1887, and the law which

1 Cong. Record, 48th Cong., 1st Sess., Part 6, 5483.

2 Ibid., Part 5, 5335.

${ }^{3}$ By yeas, 31 ; nays, 27 . Ibid., Part 6,5489 . The full text of the amendment is printed in the Congressional Record. 
President Harrison approved on June 27, 1890. With the various amendments, the Mexican War bill finally passed the Senate on June $24,1884 .^{1}$ But the Democratic House and the Republican Senate could not reach an agreement, and the measure failed to become law.

Coming between the two national conventions, the debate on the bill was quite partisan in character and revealed how large an importance the pension question had assumed in politics. The day before the bill passed Senator Vest said :'

The object of the Republican party now in this Senate is to put Democratic Senators in such a position by amendments to this bill that if we vote against it on account of the amendments, in the coming canvass we shall hear that we are opposed to pensioning the soldiers of the Union.

\section{Earlier in the debate Senator Slater of Oregon had said :}

The audacity of this thing is the only argument that I can see in favor of it. It is a political flank movement by which it is expected to defeat the universal cry for a reduction of taxation. Pass this bill and you may talk in vain about tariff reform. Before the first year of the next administration will have passed you will be seeking new objects of taxation and new means of revenue to fill your depleted Treasury. You will be unable to meet the expenses of the Government thus increased with the present revenue raised by the present taxes; you will find no place where you can put your finger to take off or lighten the taxes of the people. As I say, it is a political flank movement which is intended to defeat all propositions for the reduction of taxation or [to] bring relief to the tax-burdened people of this country.

${ }^{1}$ Cong. Record, 48th Cong., 1st Sess., Part 6, 5529. The vote was 37 yeas to 27 nays. The New York Sun of June 26, 1884, said: "The accumulated pension schemes now before Congress have assumed the proportions of legislative insanity. Congress is considering with feverish earnestness projects which, had they not reached their present dimensions by insensible gradations, would be regarded as the chimeras of madmen."

2 Ibid., Part 6, 5490.

3 Ibid., Part 5, 5048. 
One other extract, from a speech by Senator Saulsbury, is worth quoting for its statement of the part played by the claim agents in securing pension legislation. ${ }^{1}$ He said that there were obvious reasons why it was useless to oppose measures taking money out of the public Treasury for the benefit of soldiers:

In the first place, the soldiers have votes and we are all human beings and controlled somewhat by motives of selfinterest. I venture the assertion here that if the soldiers had no votes we would have no such bills pending before the National Legislature as the Mexican pension bill or the amendment offered by the Senator from Nebraska [the Cullom bill].

In the second place, we flatter ourselves that we are great men. We are the Senators of the United States who make laws for the people; but behind us there is another power greater than ourselves controlling our action if not our judgment. The pension agents who sit around this Capitol issue their circulars and decrees, and petitions come up for pensions, and the Senators of the United States, great and mighty as they may be, bow to the behests of the pension agents and vote the money that they require, and they are afraid not to do it for fear that they would lose political status at home. We all know it, and the country knows it.

[The pension agents], hoping to make a fee for themselves, send out their circulars and get up a clamor in favor of pensions, and if that will not answer they send out their instructions to have State Legislatures instruct their Senators and Representatives to vote for every character of pension bills. . . . I do believe in instructions when the Legislature fully understand what they are doing; but in this case they could not have understood it, because the bill was not formed, and they knew nothing of its details. Besides that, the instructions that have been sent from several States to Representatives upon this floor were inspired, I have no doubt, from this city, in order to influence the action of gentlemen who would not otherwise have voted for the bill.

1 Cong. Record, 48th Cong., 1st Sess., Part 5, 5045, 5046. 
Confirmation of Senator Saulsbury's statements is found in Mr. Lemon's, testimony before the House investigating committee in January, 1885. ${ }^{1}$ He said that he had sent out 15,000 or 20,000 petitions to be signed in favor of the Mexican War pension bill. These petitions came back to him and were then referred to members of Congress. While the Mexican War bill (with the Cullom bill as an amendment), was before the Senate, the National Tribune was earnestly supporting it. When it failed, Mr. Lemon's paper advised its readers editorially on July 10, 1884: "Let no soldier forget that this bill was passed by a Republican majority in the Senate, and met its death at the hands of a Democratic majority in the House."

In the contest for the soldier vote, the action of the Democratic convention at Chicago in July next became of importance. On the subject of pensions, the platform did not commit the party to any of the measures then pending. But it advocated the use of the internal revenue taxes, so long as continued, to create a fund out of which "to defray the expenses of the care and comfort of worthy soldiers disabled in the line of duty in the wars of the republic" and for such pensions as Congress might from time to time grant to such soldiers. The idea of the framers of the plank seems to have been that the internal revenue taxes were war taxes, and that it would be especially appropriate to devote them to this military purpose. The National Tribune and other leaders of the pension movement had opposed the repeal or reduction of the internal revenue taxes as lessening the funds available for pensions, and the Democratic platform proposal was doubtless drafted with their attitude in mind. ${ }^{2}$

${ }^{1}$ House Reports, 48th Cong., 2d Sess., Report No. 2683, 17.

2 The National Tribune repeatedly fought the reduction of internal revenue or tariff taxes. It said on March 8, 1883: "The fact remains that by the passage of the tariff bill Congress has very materially reduced the revenues of the Government, and to that extent impaired the chances of a fuller recognition of the soldiers' claims by its successor. The exact extent of the mischief which has been done can not as yet be accurately estimated." On similar grounds, it vigorously opposed the repeal or reduction of the internal revenue taxes in editorials on January 4, 1883; February 15, 1883; March 8, 1883. It urged the ex-soldiers to write to their representatives in Congress against any modification of the internal revenue system, and said (March 8 , 
As the soldiers' paper with the largest circulation, the National Tribune was favorable in 1884 to the Republican candidates without making an open campaign. It pronounced the Republican pledge of a repeal of the arrears limitation more satisfactory to the soldiers than the Democratic suggestion that the internal revenue receipts be segregated to create a pension fund. The "soldiers' ticket," Blaine and Logan, was preferred to the ticket with "not a soldier on it," Cleveland and Hendricks." Probably a prudent regard for the uncertainties of politics and a desire to keep the pension movement in favor whichever party won kept Mr. Lemon's organ from aggressive partisanship at that time. ${ }^{2}$ However, the records of members of Congress on pension bills were published during the campaign, and the veterans in both parties were urged to demand nominees pledged to their interests. ${ }^{3}$ At the close of the campaign on November 6, 1884, the National Tribune said:

The matter of justice to soldiers has entered into every Congressional canvass north of the Potomac and Ohio. Every candidate for Congress has been made to feel that proper treatment of the Nation's defenders was one of the first of his duties if elected. This splendid result has been secured by the agitation in which the National Tribune has taken a leading and determined part, and by the increase in numbers and influence of the G. A. R.

1883) that, while a reduction had been made, they had carried their main point against the abolition of the system. The New York Sun said, January 24, 1884: "The war claim agents now substantially control the finances of the country through the legislation relating to them. They have concocted the schemes, and then drummed up the support for them, which have kept the internal revenue system alive until now. They propose to perpetuate this system. solely that there may be surplus enough in the Treasury for the prodigious job of war claim plunder which they see ahead." (Last paragraph from an editorial entitled "A Mighty Scheme of Spoliation.")

1 National Tribune, July 17, 1884.

$2 \mathrm{Mr}$. Lemon's friend and employe, Past Commander-in-Chief Paul Van Dervoort of the G. A. R., campaigned for Blaine and Logan in 1884. The National Tribune was also engaged in selling a "Life of Logan" during the campaign.

3 The National Tribune of June 19, 1884, had noted the nomination for Congress by the Republicans in Ohio of Gen. Charles H. Grosvenor of the Committee on Pensions of the Grand Army of the Republic. It expressed the hope that many more such nominations would be made. 
When the 48th Congress met for its second session in December, 1884, the political atmosphere was decidedly less favorable to new and pending pension projects than at the previous session. Although the efforts of the claim agents had resulted in a large number of petitions being sent to the House for the passage of the Mexican War pension bill with the Senate's Civil War amendments, the House refused to concur in the Senate amendments when a motion was made to suspend the rules for that purpose. ${ }^{1}$ The Senate also exhibited a more moderate attitude in pension matters, and Senator Ingalls found little support in a perfunctory attempt to have the Committee on Pensions discharged from the consideration of his bill removing the arrears limitation. ${ }^{2}$

Committees of the Democratic House lost little time in beginning investigations of the activities of Commissioner of Pensions Dudley and other officers of the Pension Bureau in connection with the October election in Ohio and the November election in Indiana. ${ }^{3}$ Before the elections Commissioner Dudley resigned to take effect November 10,1884 , and, in the meantime, secured leave of absence from his duties at Washington. In October he was at Columbus managing the Republican campaign in Ohio. Later he went to Indiana and engaged in the canvass of that state for the November elections. ${ }^{4}$ Mr. E. G. Rathbone, chief of the special examiners' division of the Pension Bureau, was also in both of these states engaged in similar work. Over 100 special examiners of the Bureau were in Ohio during October, some on regular duty and others on leave of absence. Practically all were Republicans. The normal number of special examiners employed in Ohio was a little over sixty. It was charged by the Democrats that these special examiners were sent

1 Cong. Record, 48th Cong., 2d Sess., Part 1, 459.

2 Senator Ingalls made the motion on January 6,1885 , a week before the meeting of the Kansas legislature which reelected him.

${ }^{3}$ House Reports, 48th Cong., 2d Sess., Nos. 2681 and 2683.

$4 \mathrm{Mr}$. Dudley is the same person who gained considerable notoriety in the campaign of 1888 in connection with a letter he is said to have written to party leaders in Indiana, instructing them to: "Divide the floaters into blocks of five." New York Times, October 31, 1888. 
into close Congressional districts and that they gave pension claimants to understand that it would be to their advantage to vote the Republican ticket. Commissioner Dudley used several of the employes of the Bureau as personal assistants. In one Indiana case it appeared that the Republican candidate received unusual favors from the Pension Bureau in the matter of expediting pension cases to aid his campaign against the sitting Democratic member. While this political work was going on, the special examiners' division at Washington became demoralized. $^{1}$ Leading newspapers and the civil service reformers protested vigorously against these political activities of officers in the pay of the federal government. ${ }^{2}$ When Dudley retired from the Pension Office, he was succeeded for a few months by O. P. G. Clarke who had been Deputy Commissioner. ${ }^{3}$ In March, 1885, President Cleveland appointed John C. Black of Illinois Commissioner of Pensions.

Under the new Commissioner of Pensions there was a considerable reorganization of the Pension Bureau and particularly of the special examiners' service. In his report for 1885 , Commissioner Black said that the Pension Bureau had been "all but avowedly a political machine, filled from border to border with the uncompromising adherents of a single organization.

1 The investigation of the conduct of Pension Office officials in connection with the elections in Ohio and Indiana was conducted by the House Select Committee on Payment of Pensions, Bounty, and Back Pay. The testimony is found in Part 2 of House Report 2683, 48th Cong., 2d. Sess.

2 The New York Times said, October 20, 1884:" "The prostitution of the power of the Pension Bureau to base partisan uses in Ohio is one of the most contemptible tricks to which the Blaine men have resorted. . . . It is estimated by careful observers that several thousand votes were influenced by promises to pension claimants of that 'favoritism' in which Mr. Blaine is a confessed trafficker." The same paper said on October 21: "The special agents of the Pension Bureau who bought votes for the Republican ticket in Ohio by assuring pension claimants that, in return for their political support, their claims would be advanced on the list and adjusted at an early date are now at work in Indiana." These charges were denied by the officials concerned.

3 For a more detailed account of Commissioner Dudley's political activities in Ohio and Indiana in 1884 , see pages 105 to 115 of a recently published monograph by Dr. John W. Oliver, entitled History of the Civil War Military Pensions, I86I-1885. (Madison, Wis., 1917.) 
The enormous array of the medical boards established in every quarter was almost solidly partisan; made so not openly but surely. People of one faith filled every one of the great agencies. Examiners, trained in unscrupulous schools, traversed the land as recruiting sergeants for a party . . . a tide of men and money was poured by this office into the sections where political struggle was progressing." The Commissioner said that his intention was to have all parties represented among the employes and to put the Bureau on a business basis.

Another abuse mentioned was that employes had been appointed in the Pension Bureau through the influence of outside parties, and afterwards had acted as agents to aid in the preparation of cases which the outside parties were prosecuting. One clerk had confessed to the Commissioner that he acted as agent for one man in aiding to prepare from 300 to 400 cases. $^{3}$

Commissioner Black was a Union veteran and disposed to administer the pension laws in a liberal spirit. He even went so far as to advocate strongly in his first report a repeal of the arrears limitation in the act of 1879 , thus supporting a proposal whose principal sponsors up to that time had been Republicans.

A bill to repeal the arrears limitation was introduced into the House in December, 1885, and reported favorably by the Committee on Invalid Pensions in March, 1886. ${ }^{2}$ The Committee, however, added an amendment establishing January 1, 1888, as a new date of limitation. In connection with this bill General Black reported that the total amount paid for arrears under the act of 1879 up to June 30,1885 , was $\$ 179,400,000$. He thought that the total expenditure for arrears under the act of 1879 would reach $\$ 260,000,000$. As to the cost of a new law repeal-

1 House Ex. Doc., 49th Cong., 1st Sess., Doc. 1, Part 5, Report of the Commissioner of Pensions, 110-111.

${ }^{2}$ House Reports, 49th Cong., 1st Sess., No. 783. Includes quotation from General Black's letter and a report of his appearance before the House Committee. 
ing the arrears limitation, he was not very definite. He at first placed it at $\$ 303,000,000$, and later said that he had discovered an error which made $\$ 222,000,000$ an outside estimate. The Committee on Invalid Pensions estimated $\$ 150,000,000$. As a matter of fact, estimating was largely a matter of speculating upon how many new applications would come in, and what percentage would be allowed of the claims on file and which should be made in the future, and at what rates they would be allowed. The bill to repeal the arrears limitation made no progress. When the Republicans were again in power in 1890, an official estimate was made that the cost of a repeal of the arrears limitation would be $\$ 471,000,000 .^{1}$ The pledge in the party platform of 1884 was never redeemed.

However, there was a partial repeal of the arrears limitation in favor of widow pensioners and claimants by the following provision in the pension appropriation act of June $7,1888:^{2}$

That all pensions which have been, or which may hereafter be, granted under the general laws regulating pensions to widows in consequence of death occurring from a cause which originated in the service since the fourth day of March, eighteen hundred and sixty-one, shall commence from the date of death of the husband.

This provision was a Senate amendment estimated to cost about $\$ 1,500,000$ up to June 30,1889 , and an indefinite annual amount thereafter. $^{3}$ In so far as it applied to widows' pensions in the future, the act did not seem likely to be very costly in the majority of cases. It was thought that most widows would, in any case, apply within a year of the date of death of the husband, and the arrears from the date of application back to the date of death would be moderate in amount. The unconsidered aspect of the question was the existence of widows who had never

1 Senate Reports, 51st Cong., 1st Sess., No. 989, 25-26.

$2 U$. S. Statutes at Large, xxv, 173.

3 Senate Reports, 50th Cong., 1st Sess., No. 1285. Also Cong. Record, 50th Cong., 1st Sess., 4151-4159, 4161, 4300, 4308. 
applied for a pension, although the soldier husbands had died soon after the war. Many such widows had remarried without ever having received a pension. Commissioner Evans, in his report for 1899, pointed out that the act of 1888 was subject to abuse in enabling such remarried widows to collect large sums of arrears, frequently to the benefit of the second husband who never had connection with the United States military service.

In his report for 1898, Commissioner Evans gave the following illustration of the operation of the act of 1888 in the case of the widow of a captain of volunteer infantry:

In 1871 this captain died. He was not a pensioner, and never had filed a claim for pension. His widow remained a widow until March 30. 1887, when she remarried, having filed no claim, and, having remarried, had no pensionable status. In 1893, five years after the act of June 7, 1888, had passed, six years after her remarriage, and twenty-two years after the death of her soldier husband, she files her claim for pension as a widow, from the date of the death of her soldier husband, in 1871, to the date of her remarriage in 1887 - sixteen years-and gets nearly $\$ 4,000$, practically for the use and benefit of the second husband.

The increase of widows' claims immediately following the act of 1888 was not alarmingly great. ${ }^{1}$ But, in the long run, the act was a weak point in the pension system, where the possibility of gaining thousands of dollars of arrears was a strong temptation to the unscrupulous to commit fraud. Commissioner Evans said in 1899 of the methods which had been used :2

The records of national cemeteries have been brought into use for the purpose of determining the names and service of those buried there. Women are then hunted up who are induced to execute applications for pension on account of

\footnotetext{
1 The number of original Civil War widows' claims (army and navy) filed in each of the following years was as follows: 1886, 13,503;1887, 16.595; $1888,19,695 ; 1889,24,176 ; 1890,29,153 ; 1891,18,111 ; 1892,16,169 ; 1893,12,358$.

2 See pages 21 and 22 in pamphlet Report of the Commissioner of Pensions for 1899 .
} 
the service and death of these soldiers. These women become pliant tools in the hands of the operators. A prima facie case is made out by means of "stock witnesses," and the originator of the fraud pockets the amount of the first payment, leaving the fraudulent claimant to reap the benefits of the future payments. Great difficulty is often experienced by this Bureau in disproving a marriage or marriage relations alleged to have occurred thirty or forty years ago.

This law, like the original Arrears Act, put a premium on crime, and, under the e.x parte system of adjudicating claims, the government did not have adequate means of protecting itself. While occasionally the fraudulent nature of claims was discovered, there is no doubt that many improper claims succeeded and that the Treasury suffered considerable losses thereby.

Though the entire removal of the limitation on the payment of arrears long remained an object of desire on the part of many of the ex-soldiers, in the late eighties sweeping pension proposals of another nature were put forward. By reason of their adoption and execution, so much money was required as to make the removal of the arrears limitation out of the question.

The Pension Bureau has furnished no systematic statement of the amount of arrears paid out under the act of 1879 and amendatory legislation. However, the following table shows the relative amounts disbursed for first and subsequent pension payments for the years named : ${ }^{1}$

${ }^{1}$ From Statistical Abstract of the United States for 1899, 422. The total disbursements differ slightly from revised figures given in recent reports of the Commissioner of Pensions. 


\begin{tabular}{|c|c|c|c|}
\hline $\begin{array}{c}\text { Year Ending } \\
\text { June } 30\end{array}$ & First Payments & $\begin{array}{l}\text { Pensions Exclusive } \\
\text { of First Payments }\end{array}$ & $\begin{array}{c}\text { Total } \\
\text { Disbursements }\end{array}$ \\
\hline & Dollars & Dollars & Dollars \\
\hline 1877. & $3,284,937.12$ & $24,837,746.36$ & $28,580,157.04$ \\
\hline $1878 .$. & $2,992,352.17$ & $23,538,439.93$ & $26,844,415.18$ \\
\hline $1879 \ldots$ & $5,763,758.60$ & $27,725,979.96$ & $33,780,526.19$ \\
\hline $1880 \ldots$ & $12,468,191.20$ & $44,558,802.92$ & $57,240.540 .14$ \\
\hline $1881 \ldots$ & $23,628,176.61$ & $26,458,498.14$ & $50,626,538.51$ \\
\hline 1882. & $26,421,669.19$ & $27,408,390.05$ & 54.296 .280 .54 \\
\hline 1883. . & $29,906,753.94$ & $29,915,480.89$ & $60,431,972.85$ \\
\hline $1884 \ldots$ & $23,413,815.10$ & $32,682,126.58$ & $57,273,536.74$ \\
\hline $1885 \ldots$ & $27,115,912.21$ & $37,817,375.91$ & $65,693,706.72$ \\
\hline $1886 \ldots$ & $22,137,054.16$ & $41,621,591.49$ & $64,584,270.45$ \\
\hline $1887 .$. & $25,166,990.06$ & $48,300,591.81$ & $74,815,486.85$ \\
\hline 1888. & $22,299,605.46$ & $56,568,841.28$ & $79,646,146.37$ \\
\hline 1889. & $21,442,349.13$ & $66,832,764.15$ & $89,131,968.44$ \\
\hline 1890. & $38,721,866.03$ & $66,806,314.35$ & $106,493,890.19$ \\
\hline $1891 \ldots$ & $38,652,274.31$ & $78,326,898.41$ & $118,548,959.71$ \\
\hline 1892. & $45,114,167.68$ & $94,045,188.71$ & $141,086,948.84$ \\
\hline $1893 .$. & $33,756,549.38$ & $122,983,917.76$ & $158,155,342.51$ \\
\hline 1894. & $11,917,359.58$ & $127,887,101.47$ & $140,772,163.78$ \\
\hline 1895. & $11,451,133.01$ & $128,356,204.29$ & $140,959,361.37$ \\
\hline $1896 \ldots$ & $11,289.278 .48$ & $126,925,483.46$ & $139,280,078.15$ \\
\hline 1897 & $12,575,601.40$ & $127,374.115 .95$ & $139,949,717.35$ \\
\hline $1898 \ldots \ldots$ & $15,542,914.03$ & $129,108,965.77$ & $144,651,879.30$ \\
\hline 189 & $9,247,957.75$ & $129,107,095.20$ & $138,355,052.95$ \\
\hline
\end{tabular}

The table shows the remarkable increase in the amounts of first payments in the ten years following the passage of the Arrears Act. Such payments were very largely arrears under the act of 1879 . In 1880 there was an unusually large expenditure for pensions exclusive of first payments. This was doubtless due to the payment of arrears to pensioners already on the rolls, in which case the arrears would not be first payments. Another element appearing in first payments is back pension to cover the period-often several years-between the time of filing the application for a pension and the date when the claim is finally allowed by the Pension Bureau. This element is an important part of the first payments after the passage of the act of June 27, 1890. The first payments in 1892 were the largest in the history of the Pension Bureau. The Arrears Act was also a powerful stimulus to the building up of the permanent pension list, aithough many of the original claims filed before the arrears limitation expired were not favorably passed upon by the Pension Bureau for many years after 1879 . 


\section{CHAPTER III}

Civil War Pensions-The Act of June 27, 1890, and ServicePensions-Pensions and Politics

From 1861 down to June 30, 1885, 555,038 pension claims were filed alleging the existence of disabilities of service origin, and 300,204 of these claims were allowed under the provisions of the general pension law. Likewise 335,296 claims of widows, minor children, or dependent relatives were filed during the same period, alleging death of the soldiers to have been due to causes originating in the military service. Of these claims on behalf of widows and other relatives, 220,825 were allowed. ${ }^{1}$ Thus at the close of the fiscal year 1885 there were 254,834 invalid claims and 114,471 claims of widows and relatives, which had not been acted on favorably. Some were pending; some had been rejected but might be reopened on the discovery of necessary evidence.

The great obstacle to passing favorably on these hundreds of thousands of claims was the requirement of the pension law that proof must be made that disability and death were due to military service. In some meritorious cases, the lapse of years since the war and the absence of record evidence made it difficult or impossible to comply with the requirements of the law. In many other cases, it was improbable that the soldier's disability or death had any relation to military service. These conditions brought on a movement for the introduction of a new principle into Civil War pension legislation-that of granting pensions to persons who had performed a certain period of military service, provided they suffered from disabilities, but regardless of the origin of such disabilities. In some of the bills proposed, the grant of a pension was conditioned upon the claimant being de-

\footnotetext{
1 Report of the Commissioner of Pensions for 1885. House Ex. Doc.. 49th Cong., 1st Sess., Doc. 1, Part 5, 100.
} 
pendent upon his daily labor, or upon the contributions of others, for his support. The movement also had in view the pensioning of widows of soldiers who served the required period, without regard to the cause of the soldier's death. Measures put forward to carry out these plans were known as "dependent" or "disability" pension bills.

Contemporaneously with the above movement, there was a widespread agitation on the part of ex-soldiers and G. A. R. posts for universal service-pensions. The appetite for pensions had grown keen, and soldier politicians found it to their advantage to go about asserting that all the veterans ought to be pensioned, whether disabled and indigent or not. At the G. A. R. national encampment of 1887, Comrade Johnston of Indiana, a member of Congress, said : ${ }^{1}$

I may go into the rural districts, and let Comrade Hamlin go with me and tramp up and down the Wabash Valley, - taking the soldiers as they come, and nine out of every ten, Democrat and Republican, are in favor of a service pension bill. We are here to legislate for that. Let me give you a little piece of history. The gallant General Hovey of Indiana, ${ }^{2}$ Captain White of Fort Wayne, and myself represent three districts in Indiana, and in each of those districts the majority against us is from twelve to fifteen hundred. We held a council of war. We declared in favor of a universal pension. Our opponents were foolish enough to fall into the trap and opposed it. Hovey carried his district by fourteen hundred majority. Captain White carried his by over twelve hundred, and I carried mine by eleven hundred and fifty. When I talk, I am talking for the men who represent the rank and file in the Grand Army.

A large element in the G. A. R., including the Committee on Pensions, thought it wise policy to postpone the demand for service-pensions and to concentrate all effort on a "disability"

1 Journal of the 2Ist National Encampment, G. A. R., 1887, 231-232.

2 General A. P. Hovey was President of the Service Pension Association of the United States. He made a political issue of the pension question and was elected governor of Indiana on the Republican ticket in 1888. 
measure. Comrade Hannibal Hamlin of Maine said at the same encampment : ${ }^{1}$

We have a presidential election coming, and I tell you that there is a power behind that. I am no prophet, but I would predict that a President who will again veto a Disability Pension Bill can never be reelected President of the United States. You put to them a Service Bill, and I am not quite sure that a veto would have the same result. Let us be careful and wise in what we are doing. Keep within proper limits. We simply say now we will express no opinions. Don't kill the Disability Pension Bill by asking for a great deal more.

There were also those in the G. A. R. who put opposition to service-pensions on higher ground than that of prudence. Of the demand for such pensions, Comrade Burdett said in the same discussion: ${ }^{2}$

I can see no other answer than that it is setting up our patriotism against pay. When Abraham Iincoln-whose name be blessed forever-cried: "To your tents, O Israel!" the roads and the byways were thronged with the feet of them who rushed to the recruiting stations and thousands were turned away. That was the grandest sight the sun ever shone upon. A nation of gentlemen and patriots, not asking what the pay should be, came rushing to the front. I protest against spoiling that immortal picture by now calling the remnant of that great host again around the moneychangers' table to receive a pittance of eight dollars a month. . . This is a great republic, and if it lives it is to live upon the unpaid patriotism of its sons. And I protest that the Grand Army, last of all, should set an example for future times of seeking to set a money value upon its services.

These extracts from the debate between the advocates of service-pensions and the advocates of disability pensions are

1 Journal of the 2Ist National Encampment, G. A. R., 1887, 231.

2 Ibid., 229. 
given as typical of what took place at several of the Grand Army encampments. The supporters of service-pension proposals gained in numbers from year to year, and were in control at the encampment of 1888 . At that time a report was adopted by a vote of 446 to 22 which favored the presentation of a bill to Congress making provision that every soldier or sailor who served in the Civil War for a period of sixty days or more should receive a service-pension of eight dollars per month, and that all who served a period exceeding eight hundred days should have one cent added to the monthly pension for each additional day's service. However, the same report added that "we do not withdraw our repeated approval of the bill now before Congress, which was proposed and endorsed by the National Pension Committee of the Grand Army, known as the disability pension bill." ${ }^{1}$

The experienced members of the pension committee were right in their opinion that there was a chance for a "disability" or "dependent" pension bill in Congress, but no immediate possibility of the passage of the Universal Service-Pension Bill. The Senate, as early as the summer of 1884 , had adopted a disability pension measure as an amendment to the Mexican War bill, but the amended bill failed in the House. In his annual message for 1886, President Cleveland included a passage expressing "tender consideration" for the ex-soldiers, "who, having served their country long and well, are reduced to destitution and dependence, not as an incident of their service, but with advancing age or through sickness or misfortune." Of this class of veterans he said :

We are all tempted by the contemplation of such a condition to supply relief, and are often impatient of the limitations of public duty. Yielding to no one in the desire to indulge this feeling of consideration, I can not rid myself of the conviction that if these ex-soldiers are to be relieved, they and their cause are entitled to the benefit of an enactment under which relief may be claimed as a right, and that

1 Journal of the 22d National Encampment, G. A. R., 1888, 190-191. 
such relief should be granted under the sanction of law, not in evasion of it; nor should such worthy objects of care, all equally entitled, be remitted to the unequal operation of sympathy, or the tender mercies of social and political influence with their unjust discriminations. ${ }^{1}$

The President having thus expressed himself as favorable to an extension of the pension laws for the benefit of dependent and destitute soldiers, Mr. Matson of Indiana, on January 10, 1887, introduced a Dependent Pension Bill into the House of Representatives. It was referred to the Committee on Invalid Pensions, from which Mr. Matson reported it on January 17, 1887. He moved that the rules be suspended and the bill be passed. ${ }^{2}$ The measure provided a pension of $\$ 12$ a month for total inability to procure a subsistence by daily labor. A pension of this amount might be granted to all persons who had served three months or more in any war in which the United States had been engaged and had been honorably discharged, provided they were, or should thereafter be, "suffering from mental or physical disability, not the result of their own vicious habits or gross carelessness, which" incapacitated "them for the performance of labor in such a degree as to render them unable to earn a support," and provided they were dependent upon their daily labor for a support.

Mr. Matson, in charge of the bill, said that it was a charity measure to take ex-soldiers from the poor-houses of the country. "It is in the line of action suggested by the Chief Executive in his last annual message." He estimated that it would require less than six millions of dollars per annum to pay the expenses of all the pensions provided for in the bill. But, in the brief debate, it appeared that the so-called estimate was based on very meager information. Critics objected that the bill as drafted would encourage pauperism and would undoubtedly cost a great

\footnotetext{
1 President Cleveland dealt with the matter of pensions at considerable length in this message. He argued that a resort to special pension acts produced inequalities and unjust discriminations. He had especially in mind provision by general law for ex-soldiers who were being supported by public or private charity. Message and Documents, 1886-87, 32-34.

${ }^{2}$ Cong. Record, 49th Cong., 2d Sess., Part 1, 495, 739-743.
} 
deal more than expected. It was urged that the pensions ought to be proportionate to the degree of disability and that the "purely pauper feature" ought to be stricken out. No amendment was permitted, and the bill passed by yeas 180 and nays 76 .

Already, in May, 1886, the Senate had passed a bill "for the relief of soldiers of the late war honorably discharged after three months' service, who are disabled and dependent upon their own labor for support." ${ }^{1}$ This was more liberal in its terms than the Dependent Pension Bill and was supported by the Pension Committee of the G. A. R., at whose request a large number of petitions were sent to Congress in its favor. The House did not act on the Senate bill, but the Dependent Pension Bill above described was finally reported and passed in its stead. At the time of the passage of the dependent bill, the G. A. R. Pension Committee were in session in Washington. ${ }^{2}$ Although they thought the House measure unduly conservative, they decided to accept it because of the fact that it established the principle "that a pension might be granted for present need or disability, without absolute proof that such disability arose from service in the war against rebellion, and could be traced in unbroken continuance through the intervening quarter of a century." Therefore they sought a hearing beforc the Senate Committee on Pensions and urged that the Dependent Pension Bill, in order to make sure of its success, be passed by the Senate without change. The Senate Committee unanimously so voted, and the bill was reported the same day. On January 27,1887 , it was passed without amendment and without a roll call. Senators, however, took occasion to call attention to the more liberal terms of the bill which their body had passed in the previous year. ${ }^{3}$

Owing to a formal motion to reconsider in the Senate, the De-

${ }^{1}$ Cong. Record, 49th Cong., 1st Sess., Part 5, 4667-4681.

2 For the pension committee's report to the annual encampment of the G. A. R., see Journal of the 2Ist National Encampnent, G. A. R., 1887, 164 169.

${ }^{3}$ For the course of the Dependent Pension Bill in the Senate, see Cong. Record, 49th Cong., 2d Sess., Part 1, 793; Part 2, 1067-1076, 1100, 1124, 1140, 1177. 
pendent Pension Bill was not sent to President Cleveland until January 31. While the bill was in the President's hands, expressions of opinion as to his duty in the matter appeared in various newspapers. On behalf of the ex-soldier claimants, the National Tribune on February 3 published a long open letter urging him to sign. The New York Times was a leader in denouncing the bill, and in repeated editorials it advocated a veto. ${ }^{1}$ Mr. Cleveland retained the measure until the very last day allowed him for its consideration under the provisions of the Constitution, returning it to the House of Representatives without his approval on February 11, 1887. ${ }^{2}$

In a lengthy veto message, the President said that the Dependent Pension Bill was the first measure sanctioned by Congress granting pensions to the soldiers and sailors of the Civil War upon the ground of service and present disability alone, and in the entire absence of any injuries caused by military service. Upon an analysis of the provisions of the bill, he thought its language uncertain, liable to conflicting constructions, and subject to unjust and mischievous application. In interpreting it, the chairman of the Committee on Invalid Pensions in the House of Representatives had differed radically from the chairman of the Committee on Pensions of the Senate. The law failed to provide for any grading of the pension of $\$ 12$ a month, and President Cleveland argued that a lack, in any degree, of ability to

\footnotetext{
1 New York Times, February 4, 7, 8, 9, 10, 1887. The Times said, February 10: "We have already said that we believed the President would be fully sustained in vetoing the Dependent Pension bill by the veteran volunteers of the war for the Union and by the people generally. It is now more than probable that he would be sustained by enough members of Congress to kill 'the bill.'" The Times attributed the changed attitude to the result of reflection and understanding of the real character of the bill.

2 Shortly before the veto message reached the House of Representatives, Mr. Steele of Indiana moved to adjourn, but the motion was defeated. After the reading of the message, Mr. Steele said: "Mr. Speaker, when I moved to adjourn awhile ago, the gentleman from Kentucky [Mr. Taulbee] asked me a question which I answered under a misapprehension. He asked me if my purpose was to cut off the pension session, and, not understanding him correctly, I answered "yes." My object really was to have the House adjourn so that the message which has just been read might reach here after adjournment, and the bill therehy become a law." For the message, see Cong. Record, 49th Cong., 2d Sess., Part 2, 1637-1639.
} 
earn a support would under its terms entitle an applicant otherwise qualified to receive the full pension. If this were so, "the probable increase of expense would be almost appalling."

The President pointed out that the soldiers of the Civil War, in their pay, bounty, pension provisions, preference in public employments, and care for the needy in soldiers' homes, had "received such compensation for military service as has never been received by soldiers before, since mankind first went to war." Service-pensions had hitherto been reserved for "surviving soldiers few in number, venerable in age, after a long lapse of time since their military service, and as a parting benefaction tendered by a grateful people."

Another of the President's arguments against the proposed bill was based upon "the widespread disregard of truth and good faith" already existing in the prosecution of pension claims. In Mr. Cleveland's words:

In the execution of this proposed law under any interpretation, a wide field of inquiry would be opened for the establishment of facts largely within the knowledge of the claimants alone; and there can be no doubt that the race after the pensions offered by this bill, would not only stimulate weakness and pretended incapacity for labor, but put a further premium on dishonesty and mendacity.

The message also showed that the President was concerned over the probable effect of such a pension law in obstructing his plans for the reform of the federal system of taxation. Upon this phase of the matter he said:

Federal taxation, no less borne by the people than that directly levied upon their property, is still maintained at the rate made necessary by the exigencies of war. If this bill should become a law, with its tremendous addition to our pension obligations, I am thoroughly convinced that further efforts to reduce the Federal revenue and restore some part of it to our people, will and perhaps should be seriously questioned. 
It has constantly been a cause of pride and congratulation to the American citizen that his country is not put to the charge of maintaining a large standing army in time of peace. Yet we are now living under a war tax which has been tolerated in peaceful times to meet the obligations incurred in war. But for years past, in all parts of the country, the demand for the reduction of the burdens of taxation upon our labor and production has increased in volume and urgency.

I am not willing to approve a measure presenting the objections to which this bill is subject, and which moreover will have the effect of disappointing the expectation of the people and their desire and hope for relief from war taxation in time of peace.

Quoting from his annual message of 1886 the language regarding pensions upon which the advocates of the Dependent Pension Bill relied, Mr. Cleveland said that he did not think that the objects, the conditions, and the limitations he had suggested were contained in the bill under consideration.

But the evil threatened by this bill is in my opinion such, that, charged with a great responsibility in behalf of the people, I can not do otherwise than to bring to the consideration of this measure my best efforts of thought and judgment, and perform my constitutional duty in relation thereto, regardless of all consequences, except such as appear to me to be related to the best and highest interests of the country.

This courageous veto brought upon the President a storm of criticism and protest from those interested in the passage of the Dependent Pension Bill. The Pension Committee of the G. A. R., with the approval of Commander-in-Chief Fairchild, sent out an 'official letter recommending that "Posts and comrades everywhere, by resolutions and letters, immediately inform members of Congress-who are entitled to, and will gladly receive these expressions of opinion - of their approval or disapproval of the principles involved in the vetoed bill." Petitions soon came to Congress by the hundreds from Grand Army posts, other or- 
ganizations, and citizens for the passage of the bill over the President's veto. ${ }^{1}$ On the other hand, the majority of editorial expressions in the large newspapers of the country was favorable to the position taken by the President, even a considerable portion of the Republican press supporting him. ${ }^{2}$

On February 19 the Committee on Invalid Pensions of the House of Representatives, where the dependent bill originated, presented a report on the veto message which was in the nature of a reply to the President's objections. ${ }^{3}$ The asserted that the only fair interpretation that could be placed upon the bill was that given upon the floor of the House when it was passed, namely, that it provided but one grade of pension, $\$ 12$ a month, which was given for "total inability to procure a subsistence by daily labor." The committee quoted from the President's message in 1886 to show that he was not consistent with his former attitude, and said they had framed their bill largely in accordance with his suggestions. Since Congress had not shown a disposition to interfere with a system of taxation which produced "a

1 At the National Encampment at St. Louis in September, 1887, the pension committee reported: "The reply was prompt, vigorous and almost unanimous. With an emphasis creditable to their soldierly instincts, the three hundred thousand members of the Grand Army of the Republic, gave reply that there was neither fair fulfillment of the promises of the Nation, loyal remembrance of the sacrifices upon the altar of the Union, nor a grateful recognition of patriotic service, in a veto that doomed 25,000 veterans of the late war to remain public paupers instead of becoming deserving pensioners." Journal of the 2Ist National Encampment, G. A. R., 1887, 166, 296.

${ }^{2}$ See Public Opinion, February 19, 1887, 393-397. Out of editorial expressions from 103 newspapers on President Cleveland's veto, 74 were favorable, including 18 Republican, 18 Independent, and 38 Democrat. Those unfavorable were 28, including 26 Republican, 0 Independent, 2 Democrat. One paper was noncommittal. The Nation of February 17, 1887, called the veto of the Dependent Pension Bill the most striking event of Cleveland's administration. It said: "The veto thus presents him in the character of a careful, wise, and courageous executive, who, by the exercise of a great constitutional prerogative, has defeated an outrageous scheme which was hastily passed by Congress in a characteristic fit of carelessness, folly, and cowardice." On the other hand Mr. Lemon's National Tribune cited arguments for the bill and said: "Against all this Mr. Cleveland sets up his individual opinion and arrogantly overrides an act of Congress done with unusual deliberation, by men of the highest integrity and patriotism, in response to a public demand of extraordinary earnestness." (February 17, 1887.)

${ }^{3}$ Cong. Record, 49th Cong., 2d Sess., Part 2, 1970-1973. 
revenue far beyond that which is necessary to carry on the government economically administered," they thought that among the various schemes proposed for using the surplus the payment of pensions was the best manner of restoring it to the people. It was the unanimous recommendation of the committee that the bill pass notwithstanding the objections of the President. This report from a Democratic House committee was greeted with applause and laughter on the Republican side. It was made a special order for February 24.

When the special order was reached, the supporters of the President were led by Mr. Bragg of Wisconsin, a northern Democrat who had served gallantly as a brigadier general in the Union army. ${ }^{1}$ The debate was acrimonious at times and noteworthy for the fact that General Bragg and Mr. Warner of Ohio both thought it worth while to make sharp attacks upon the activities of Mr. Lemon and his National Tribune. After objecting to legislation that would bankrupt the country in order to obey the behests of claim agents, Mr. Bragg said:

Mr. Speaker, I listened a moment since to a gentleman "who paused for a reply." If he will read the National Tribune, published in the city of Washington-published by men who receive from $\$ 25,000$ to $\$ 45,000$ a month as fees from pensioners, blood taken from the soldiers whom they pretend to love-he will find in every column of that paper some squib, some abuse of the President of the United States and of those who dare to think differently from those men upon the propriety of the passage of this bill. These men talk about us as not being the friends of the soldiers.

Why, Mr. Speaker, these newspapers that pretend to be "friends of soldiers" are the friends of soldiers as vultures are the friends of dead bodies-because they feed and fatten on them. [Applause.] They levy their tax upon every soldier; and then they send to the member of Congress representing the district the work to be done in looking after the case. They file the application; they draw their $\$ 10$; they give notice then that the papers are complete and that

1 Cong. Record, 49th Cong., 2d Sess., Part 3, 2202-2226. 
the applicant need only send them to his member of Congress and his case will be attended to promptly. Those are the men who are the professed "friends of soldiers." They have the voice of Jacob, but their hand has the clutch of Esau.

In passing on to pay his respects to other friends of the soldier, Mr. Bragg had a clash with Mr. Henderson of Iowa:

Mr. Bragg. No, Mr. Speaker, the men who advocate this bill are not, in its advocacy, the friends of the true soldier. They advocate this bill, many of them, in my judgmentand I desire to be impersonal in my remarks-they advocate this bill, why? Simply because the men whom they expect to buy by the bill can vote.

Mr. Henderson, of Iowa. For one, I pronounce that false. [Applause on the Republican side.]

Mr. Bragg. Mr. Speaker, I say that that is the substratum upon which all this action is based-that if these men, whom they class as paupers, were to call upon them individually for aid, they would say, "You lazy, good-for-nothing scoundrel, you are as competent to work as I am." [Applause on the Democratic side.] Although gentlemen may deceive themselves into thinking that their motive here in voting for everything that has the word "pension" upon it is purely patriotic, I can say to them-and I speak the voice of the press (for every paper of any prominence in this country has been teeming with the expression of the sentiment) - if you succeed in deceiving yourselves you simply do what the ostrich does when he hides his head and thinks because he can not see anybody nobody can see him. [Laughter.]

Mr. Henderson, of Iowa. The men whose claims this bill recognizes do not subscribe for or advertise in the large papers supported by the capital of the country.

Mr. Warner of Ohio devoted a portion of his remarks to discussion of the infuence of the claim agents with the Grand Army posts :

It is true that some of the Grand Army posts have petitioned members to vote for this bill, but I think in some of 
them at least I can detect the origin of their movements. It is to be found in this paper [the National Tribune] a copy of which I hold in my hand, printed in Washington, which is the organ of the claim agents, and is edited by that scoundrel who in the last Congress admitted, on oath, that he had paid thousands of dollars to attorneys to lobby through a conference committee a bill which increased his fees from $\$ 10$ to $\$ 25$, and gave him, it has been estimated, a million and a half of dollars-taking it out of the pensions of the soldiers and their widows. ${ }^{1}$ Where the soldier gets $\$ 1$ a month pension that act gave two years' pension to this scoundrel, and he is one of the men that claim to be the special "friends of the soldier."

When my friend from Pennsylvania [Mr. Bayne] asked awhile ago for the name of some claim agent who was here urging the passage of this bill, I think if he had looked around he would have seen this same' lemon-squeezer and blood-sucker of soldiers in the gallery looking down and listening with approval to the statement of the gentleman from Pennsylvania that there were no claim agents here in the interest of this bill, and that it was not a claim agents' bill. Does not the gentleman know that the claim agents here in Washington dominate the Grand Army posts in a great measure? [Cries of "No! No!" on the Republican side.]

Mr. Warner, of Ohio. They do. They dictate the appointment of its chief officers. Army posts, too, it is saidI do not know how true it is-have come too often to be "run" by claim agents as "mouth-men," who did mighty little fighting in the war, and who try to make up for it with

1 Mr. Warner referred to the testimony of George E. I.emon in House Report No. 2683, 48th Cong., 2d Sess. Claim agent Nathan W. Fitzgerald testified that Mr. Lemon had told him that he [Lemon] had spent $\$ 50,000$ in getting the fee provision of July 4, 1884, through Congress. Mr. Lemon denied this but admitted that he had paid $\$ 3,500$ to Robert $G$. Ingersoll and others for attorneys' fees for services in connection with the passage of the bill (p. 136). In this same investigation (January 15, 1885) Mr. Lemon testified that, including claims that had been rejected, he probably had in his hands 125,000 pension claims. The claims in his office might number even as high as 150,000 . Of these 60,000 or 70,000 , and perhaps as many as 100,000 , were pending claims. He thought that he had more claims in his hands than all the other attorneys of Washington put together (pp. 14-16). For a more detailed discussion of the investigation of the passage of the fee increase provision in the act of July 4,1884 , see J. W. Oliver, History of the Civil War Military Pensions, 1861-1885, 98-102. 
mouth service long after the war is over. ${ }^{1}$ [Laughter and applause.]

When the vote finally came on the question of passing the bill over the veto, there were 175 yeas and 125 nays. So (two-thirds not having voted in the affirmative) the bill was not passed.

The veto of the Dependent Pension Bill, and the sustaining of the veto after a debate which contained passages of the above character, added greatly to the hostility to President Cleveland in G. A. R. circles. He had previously met with much criticism on account of his many vetoes of special pension acts. The National Tribune said on June 9, 1887: "Everybody who keeps informed as to the news of the day knows that for more than a year the feeling in the G. A. R. against Mr. Cleveland has been steadily rising, and that his veto of the Dependent Pension Bill fanned this to a red heat." When Mr. Cleveland was invited to visit St. Louis in September during the period of the national encampment of the G. A. R., prominent members of the organization gave public warning that he had better stay away if he wished to preserve the dignity of his office. Although he had intended to be present at the encampment, he finally declined, arranging to go to St. Louis at a later date. ${ }^{2}$

At St. Louis, Past Commander-in-Chief Van Dervoort offered and urged the adoption of, resolutions charging that the President had been guilty of "irreparable cruelty" in his veto of the Dependent Pension Bill and that he had officially insulted or slandered "the broken down and needy men to whom the nation owes

1 Although Mr. Warner's remarks were denunciatory in tone, they were supported by much sworn evidence. He was chairman of the House committee which, in 1885, investigated the passage of certain pension laws and the practice of pension agents. It was this committee that developed the fact that Past Commander-in-Chief Paul Van Dervoort of the G. A. R. was, while a member of the pension committee of the G. A. R., employed by Mr. Lemon. House Report No. 2683, 48th Cong., 2d Sess.

2 See New York Times, July 8, 9, 1887. The Times said editorially, July 8: "As the President is a Democrat, and as a new Presidential contest is coming on next year, the prominent politicians in the organization were under a strong temptation to try to swing it against the administration. Some of them being more politicians than patriots, and, not gifted with great sagacity, have plainly yielded to that temptation." 
everything." These resolutions were lost, and the encampment confined itself to the condemnation of the President's veto contained in the report of the Committee on Pensions. The committee secured the endorsement of a new pension bill which it had prepared. This new measure was similar to the one vetoed, but the "pauper clause" was omitted, making it a "disability" and not a "dependent" bill. ${ }^{1}$

In 1887 and 1888 the demands of the ex-soldiers for largely increased pension expenditures came into direct and open antagonism with the plans of the Democratic administration for revenue reduction by means of tariff revision. In vetoing the Dependent Pension Bill, President Cleveland had made much of the argument that the large expenditures probable under the bill would interfere with the removal of taxes levied at war-time rates. For years the National Tribune had been urging its hundreds of thousands of soldier readers to use their political influence against projects of federal revenue reduction, and, as the President's advocacy of tariff reform became more vigorous, the pensioners' organ redoubled its efforts to consolidate the pensioners and claimants in favor of the maintenance of the existing tariff system. To a soldier who wrote to the National Tribune objecting to its advocacy of a protective tariff because it was a partisan question, that paper replied editorially on March

1 Journal of the 2Ist National Encampment, G. A. R., 1887, 210-216, 164 169. At this encampment Comrade James Tanner of New York (Commissioner of Pensions in 1889), in the debate on a proposed service-pension bill, defended the Committee on Pensions, of which he was a member, of the charge of being "Lemon's satellites." $\mathrm{He}$ said: "We have been charged with holding meetings in the office of his paper, holding meetings with locked doors. To that I make answer here and now, that we never held a meeting in Lemon's office, that we never had a meeting with closed doors, and they lie who say it.

And another thing I will say, and I am man enough to say it anywherethat so far as my observation goes, no comrade in this encampment has a right to put himself above George E. Lemon for warm-hearted, practical comradeship in the Grand Army. I will dispose of that part of it by saying in defense to all attacks made on that line, that those who know him, know him for an honest man, and I send every friend of mine, who wants any information about the presentation of a claim to him, to this man of whom $I$ and others are accused of being satellites" (p. 227). Later in the same day Mr. Lemon subscribed through Corporal Tanner $\$ 1,000$ to the G. A. R. fund for the erection of a statue to General John A. Logan (p. 245). 
31, 1887: "Our only motive for doing it is because, for the present, a Protective Tariff and pension legislation are closely connected. The Free Traders are opposed to pension legislation because that will make a use for the money derived from duties on imports." Earlier, on February 3, 1887, the same paper said: "Soldiers everywhere should at once write to their representatives, urging with all the earnestness that they can manifest that there shall be no interference whatever with the revenues of the country until the recommendations of the G. A. R. National Pension Committee are embodied into law and put into operation." 1

The New York Times devoted some editorials to the relation between lavish projects for pension expenditures and tariff reform, and concluded that if such measures as the Blair education bill, and the pension bills advocated at the G. A. R. national encampment, were to be enacted tariff reform would be of no earthly importance. $^{2}$ It found that there were some G. A. R. delegates who were not well informed as to the effect of the measures which they supported. They favored a reduction of the tariff and at the same time a service-pension bill. Mr. Lemon, however, was well informed, and gave his editorial space freely to arguments that ex-soldiers ought to fight reductions in the federal revenues in order that the surplus might be available for pensions. $^{3}$ This was especially so after Mr. Cleveland devoted

${ }^{1}$ See memorial from John A. Logan Command No. 7, Union Veterans' Union, of Dayton, Ohio, on "Pensions, Tariff and Surplus." Presented to House of Representatives on Feb. 27, 1888, and printed in full. Cong. Record, 50th Cong., 1st Sess., Part 2, 1511-1512.

2 New York Times, August 12, 29, September 1, October 3, 1887. The Times said editorially on October 3 : "The enactment of all these measures, and perhaps of only one of them, would alone more than exhaust the entire sum available. Are the veterans blind to these facts, or do they think, with Senator Blair, that if it should be necessary to increase national taxes by even $\$ 200,000,000$ to meet pension expenses the country would submit?"

3 The National Tribune of October 27, 1887, said: "Comrades, we must change front to meet a flank attack! The enemies of soldiers have altered their field tactics. They are massing now under the banner of 'Revenue Reduction' to deliver what they hope will be a fatal assault on all manner of additional pensions, allowances and other acts of justice to the nation's saviors." During 1888 the National Tribune carried on a persistent fight against the Mills bill on the ground that it would take money from the Treasury needed to pay pensions. 
his entire annual message to tariff reform in December, 1887, saying: "Our present tariff laws, the vicious, inequitable, and illogical source of unnecessary taxation, ought to be at once revised and amended. ${ }^{1}$

On December 12, 1887, at the first session of the 50th Congress, Mr. Manderson introduced into the Senate the G. A. R. "disability" pension bill. ${ }^{2}$ He said that the bill had been endorsed at the late national encampment and that he introduced it by the unanimous request of the Pension Committee of the Grand Army of the Republic. The bill was referred to the Committee on Pensions and reported favorably. An important amendment, not desired by the G. A. R. committee, was added, restoring the principle of "dependence" in a clause providing that applicants under the measure must be "without other adequate means of self-support." 3 Much was said of the Grand Army and its activities in the debate. ${ }^{4}$ Senator Beck of Kentucky delivered a speech against the pension bill in which he pronounced it a shrewd scheme by which the protected interests proposed to use up the surplus and prevent a revision of the tariff. The latter part of this speech drifted off into a general discussion of the tariff with other Senators." Later in the debate, Senator Teller said: "I know it will be said that this is an extravagance, and that we are thus extravagant because we want to keep up the tariff. I will not discuss the tariff on this bill; and I would vote today, if we were now providing for the raising of revenue, precisely as I shall vote with a surplus in the Treasury of $\$ 100,000,000 . "$ "

1 Message and Documents, 1887-1888, 7.

${ }^{2}$ Cong. Record, 50th Cong., 1st Sess., Part 1, 22.

3 Ibid., Part 2, 1499-1501.

4 Senator Vest said: "That great military and political organization, the Grand Army of the Republic, throws its iron glove into the debates of Congress and sends to us bills through its accredited Senators; and when the President of the United States honestly and bravely discharged his executive duty and vetoed an enactment which he considered improper, he was threatened by the officers of this organization with personal insult if he dared to make his presence known in the city where it held its last meeting." Ibid., Part 2, 1589.

5 Senator Beck's speech, March 1, 1888 . Ibid., Part 2, 1627-1637.

- Cong. Record, 50th Cong., lst Sess., Part 2, 1860. 
After a great deal of highly partisan debate, the bill passed the Senate on March 8. ${ }^{1}$ It was reported with amendments in the Democratic House on April 14, but was never acted upon. ${ }^{2}$

At the Columbus encampinent of the G. A. R. in September, 1888, the Committee on Pensions made liberal use of denunciatory language in describing their experience in trying to get their bill through the House. In concluding they said: "The responsibility for the failure of your bill; the responsibility for the failure of general pension legislation of any kind or degree; the responsibility for the failure to secure for the veterans of the land even a hearing before the National House of Representatives for the present session, rests upon the Chairman of the House Committee on Invalid Pensions." 3 The gentleman who was thus so severely arraigned was the Honorable C. C. Matson of Indiana, who had on April 26 been nominated by the Democrats for the governorship of that state. ${ }^{4}$

In failing to press general pension legislation in the House, Mr. Matson was doubtless acting in harmony with the Democratic leaders who were drawing the party lines closely in support of the reduction of the revenues through tariff revision as embodied in the Mills bill. The debate on this measure, which began on April 17, 1888," and continted during the spring and early summer, showed that in the minds of a large number of members

1 Cong. Record, 50th Cong., 1st Sess., Part 2, 1866.

2 Ibid., Part 3, 2959. Mr. Bynum reported the bill with amendments for Mr. Matson who was absent. Mr. Gallinger presented a minority report (ibid., Part 4, 3142) opposing the majority's amendments, which were not desired by the G. A. R. and very much altered the character of the bill. House Reports, 50th Cong., 1st Sess., No. 1694.

3 Journal of the 22d National Encampment, G. A. R., 1888, 119-122.

4 Appleton's Annual Cyclopadia, 1888, 441-442. On August 8, the Republicans nominated as Mr. Matson's opponent General A. P. Hovey, one of the "pension statesmen" from Indiana referred to on page 205. General Hovey was President of the Service Pension Association of the United States. The National Tribune charged that President Cleveland and Colonel Matson had entered into a compact in restraint of general pension legislation, that Colonel Matson was to save the President the embarrassment of using the veto against pension projects, and that in return the administration was to aid Matson in his campaign in Indiana. It called Matson "Judas." National Tribune, September 27, October 4, 25, 1888.

5 Cong. Record, 50th Cong., 1st Sess., Part 4, 3057. 
of Congress there was a close connection between pensions, surplus, and the tariff. Democrats like Senator Beck had charged that lavish pension expenditures were part of a scheme to spend all the surplus and make tariff reduction impossible. Representative Cannon of Illinois took another view of the matter. ${ }^{1}$ In beginning a speech on the Mills bill, he said that President Cleveland ought to have signed the Dependent Pension Bill and thus have expended a part of the surplus. Payments ought to have been made on account of the national debt. "The policy of the administration," said Mr. Cannon, "from its commencement to the present time has been to pile up money in the Treasury and prevent proper legislation for the expenditure of money, so it could point to the overflowing coffers of the Treasury and demand legislation looking toward a tariff for revenue only. Sir, no man in the House or the country will more heartily support an economical expenditure of the public money than I, but true economy consists in paying the debts of the Government and keeping faith with its defenders, who did so much to preserve it." Speaker after speaker urged that the ex-soldiers had the first claim on the surplus, ${ }^{2}$ and that, after provision had been made for them, expenditures should be made to pay the national debt, for the navy, for river and harbor improvements, and for educational purposes. There was no need to reduce the tariff to get rid of the surplus. Some speakers said that if the Dependent Pension Bill then on the calendar, or a service-pension bill, was taken up and passed, a large portion, if not all, of the surplus would be

1 Speech of Mr. Cannon, May 10, 1888. Ibid., Part 4, 3934.

${ }^{2}$ Cong. Record, 50th Cong., 1st Sess., Mr. J. B. Cheadle of Indiana said: "The surplus is theirs. It belongs of right to the men who saved not only the surplus, but the Government itself, from total destruction." He argued that a material reduction of the revenue meant opposition to pensions. Part 5, 4386. See speeches of Mr. Boothman of Ohio (Part 5, 4957-4962); Mr. Peters of Kansas (Part 5, 4323); Mr. Hermann of Oregon (Part 5, 4350); Mr. Struble of Jowa (Part 5, 4127). Albert Bushnell Hart says in National Ideals Historically Traced (p. 281): "Another ideal, which at least always had a majority in Congress behind it, was that the soldiers in the Civil War had a special claim on the treasury. . . . One reason for this generosity was a new conception that it was desirable to spend money freely so that the taxes might not be reduced, and particularly the tariff taxes." 
distributed among the people. ${ }^{1}$ But Mr. Mills and the Speaker pro tempore (Benton McMillin) resisted attempts by Mr. McKinley, Mr. Cannon, Mr. Reed and others to have a day fixed for the consideration of general pension legislation. ${ }^{2}$

While the Mills bill was still in the House, the national conventions of the two political parties met. In the matter of pensions, the Democrats, who met at St. Louis on June 5, made no new promises. They said: "While carefully guarding the interests of the taxpayers and conforming strictly to the principles of justice and equity, it [the Democratic party] has paid out more for pensions and bounties to the soldiers and sailors of the Republic than was ever paid before during an equal period."s The nominees were Grover Cleveland, and Allen G. Thurman of Ohio.

The Republican convention which met at Chicago on June 19 was much more liberal in its pension utterance. It said:

The gratitude of the nation to the defenders of the Union can not be measured by laws. The legislation of Congress should conform to the pledge made by a loyal people, and be so enlarged and extended as to provide against the possibility that any man who honorably wore the Federal uniform shall become an inmate of an almshouse, or dependent upon private charity. In the presence of an overflowing treasury, it would be a public scandal to do less for those whose valorous services preserved the government. We denounce the hostile spirit shown by President Cleveland in his numerous vetoes of measures for pension relief, and the action of the Democratic House of Representatives in refusing even a consideration of general pension legislation. ${ }^{4}$

The Republican nominees were General Benjamin Harrison of Indiana and Levi P. Morton of New York. This ticket, headed

${ }^{1}$ Cong. Record, 50th Cong., 1st Sess., Part 5, 4288, 4127, 4957-4962.

Speeches of Messrs. Wickham, Struble and Boothman.

2 Ibid., Part 5, 4891.

3 Edward Stanwood, 4 History of the Presidency, i, 469.

4 Ibid., i, 477. 
by a soldier who said in one of his campaign speeches that it was "no time to be weighing the claims of old soldiers with apothecary's scales," was in contrast with the Democratic ticket headed by a President who had vetoed the Dependent Pension Bill and hundreds of special pension acts. ${ }^{2}$ A platform statement confined to what had been done was in contrast with promises of enlarged and extended provisions in the future. The soldiers were told that if the Democrats succeeded in cutting down the revenues there would be no more money for pensions. Active support was given to the Republican candidates by the National Tribune with its large circulation among the ex-soldiers. There was, however, one offsetting circumstance in the popularity with the veterans of General Black, Cleveland's Commissioner of Pensions. He had served gallantly during the Civil War, having been shot in the right forearm at the battle of Pea Ridge and in the left upper arm at the battle of Prairie Grove. In May, 1878, a Senate committee had reported that he was "a physical wreck, maimed and diseased, incapable of any effort, and much of the time confined to his bed." 3 Upon this report he had been granted by private law a pension of $\$ 100$ a month. Although he continued to draw the pension as a "physical wreck," General Black made a very active Commissioner of Pensions and was politically serviceable to the administration on the stump. ${ }^{4}$ He was charged with filling the Pension Bureau almost exclusively with Democrats, and with increasing pension allowances and payments in Indiana and other localities where his party would be helped."

1 See editorial in Indianapolis Journal, April 20, 1889.

2 Attention will be given to President Cleveland's vetoes of private pension laws in a chapter on "Special Pension Legislation." A good statement of the situation resulting from Cleveland's vetoes of private pension bills is found in D. R. Dewey, National Problems (New York, 1907), 83-85.

3 Senate Report No. 397, 45th Cong., 2d Sess., May 20, 1878.

4 Later General Black served as member of the House of Representatives and President of the United States Civil Service Commission.

5 Nezw York Tribune, Tanuary 9, 1886; March 25, 1886; April 4, 1887; January 23,1888 ; September 16, 1888; October 23, 1888. He increased the rating of many pensioners, making the increase apply to past years and carry large sums of arrears. It was charged that this was done arbitrarily and with favoritism. 
But, on the whole, the Republicans derived great political advantage from the pension issue, and it may even have been the deciding factor in the November elections. ${ }^{1}$ General Harrison defeated President Cleveland by detaching Indiana and New York from the states that had supported Cleveland in 1884. Cleveland's plurality in Indiana in 1884 was 6,500, and he was defeated in 1888 by 2,300. Associated with General Harrison on the Indiana Republican ticket in 1888 was the candidate for governor, General A. P. Hovey, President of the Service Pension Association of the United States. The record of the Republican party on pensions and its promises for the future were kept to the front during the campaign and contrasted with Cleveland's numerous pension vetoes. This must have influenced many votes in a state in which there were 38,000 federal pensioners and an indefinite number of ex-soldier claimants.

In New York Cleveland won by 1,047 plurality in 1884 and was defeated by 13,000 plurality in 1888 . There were 45,000 federal pensioners in that state in 1888 and the movement for service-pensions for all the Civil War soldiers was particularly strong. ${ }^{2}$ It will be remembered that, although Cleveland failed to carry New York in 1888, Hill, Democrat, for governor received 19,000 plurality. There were charges that the difference was due to treachery within the Democratic ranks. But may not $\mathrm{Mr}$. Cleveland's unpopularity with the ex-soldiers because of his pension record have had a large influence in reducing his vote in New York?

The Harrison administration came into power in 1889 strongly committed to further pension legislation and to a liberal administration of the Pension Bureau. Immediately after the holiday recess of Congress in the winter of 1888-89, the Pension Com-

1 A. D. Noyes says, in naming inducements to large government expenditures, "Finally there was added, in 1890 , the powerful inducement of the socalled 'Grand Army vote,' which was believed to have carried some states in the 1888 election, and which, in the judgment of politicians, could be controlled by the largess of the Pension Bureau." Noyes, Forty Years of American Finance, 133-134.

2 Journal of the 22d National Encampment, G. A. R., 1888, 156-158. 
mittee of the G. A. R. held a meeting in Chicago. From thence, by appointment, they called upon President-elect Harrison at his home in Indianapolis. They received from him "the most cordial assurances of his warm interest in the great question of pensions and his earnest desire for generous legislation in behalf of the defenders of the Union."'

After President Harrison had been inaugurated, he made sure that soldiers' claims would not be weighed "with apothecary's scales" by appointing James Tanner Commissioner of Pensions. Mr. Harrison is said to have instructed him to "be liberal with the boys." Tanner was a veteran who had lost both legs in service, and he was generally known as Corporal Tanner. $\mathrm{He}$ had served for many years on the G. A. R. Pension Committee, lobbying for more liberal pension legislation. Tanner had been a claim agent, and was a warm friend of George E. Lemon, the leading Washington pension attorney. He had the reputation of being a man of personal honesty, warm hearted and impulsive. But he was an enthusiast about pensions and started out with entire seriousness of purpose to distribute the surplus to the exsoldiers. Nor did he hesitate to give his purpose publicity. "I will drive a six-mule team through the Treasury," he was reported to have said in a public speech after his appointment, and on another occasion, "God help the surplus!"' His appointment gave great satisfaction both to the G. A. R. and to the Washington pension attorneys. ${ }^{3}$

Once in control of the Pension Bureau, Commissioner Tanner found that an extension of the practice of rerating (which had prevailed to some extent under Commissioners Dudley and Black) afforded the easiest way to begin the distribution of the surplus. In his enthusiastic zeal, he even rerated pensioners who

\footnotetext{
1 Journal of the 23d National Encampment, G. A. R., 1889, 121.

2 See Nation, May 30, 1889; excerpts from various newspapers in Public Opinion, September 21, 1889; Indianapolis Journal, April 20, 1889. There may be verbal inaccuracy in the remarks attributed by the press to President Harrison and Commissioner Tanner, but they are substantially true in spirit.

3 The New York Times of March 27, 1889, says the Tanner appointment gave "extraordinary satisfaction" to the Washington pension attorneys.
} 
had made no application and sent them checks for thousands of dollars of back pension. Employes of the Bureau were given a generous share in the pleasant distribution. ${ }^{1} \quad$ Political champions of the ex-soldiers like Senator Manderson of Nebraska were rerated without solicitation and received handsome sums from the Treasury. ${ }^{2}$ But before many months the energetic liberality of the Commissioner was halted by the Secretary of the Interior. Mr. Noble wrote him on July 24, 1889 :

It 'may be that this Government is strong and great, and has at its command a surplus that no other nation has ever had, but if sums of money to the amounts above mentioned may be granted without any further consideration of fact or law than seems to have been given in these cases, it will depend solely upon a single officer's disposition whether the resources of the Government shall be sufficient for its maintenance or not. There are more than enough of these applications already in the field, and increasing daily, to exhaust indeed the surplus, of which so much has been said in connection with this matter, and I am informed that the applications for reratings are greatly on the increase, and now reach the amount of from seven to eight thousand a week. ${ }^{3}$

Commissioner Tanner questioned Secretary Noble's powers of

${ }^{1}$ In ten cases of employes reviewed by the Secretary of the Interior, sums aggregating over $\$ 16,000$ were paid as arrears of increase. The case of Frank A. Butts is typical. He was a principal examiner in the Pension Bureau at a salary of $\$ 2,000$ a year. His original application for pension was filed December 6, 1879, alleging disability from malarial disease. He was twice examined by boards of surgeons and found not disabled. Finally he was granted a pension on March 13, 1882, for disability from malarial poisoning at the rate of $\$ 7.50$ from August 1,1865 . He was examined by a board of surgeons of the Pension Office on April 29, 1889. On May 3, 1889, Commissioner Tanner reissucd his certificate, allowing the rate of $\$ 17$ a month from August 31,1865 , and $\$ 30$ from April 27, 1889; the total amount allowed under this last decision being $\$ 2,196.54$, which was paid to the pensioner on Commissioner Tanner's requisition. Some of these cases were " 48 hour cases," that is, they were hurried through an examination and the pension was increased within two days. House Ex. Doc., 51st Cong., 1st Sess., Report of Secretary of Interior, clvi.

2 Commissioner Tanner rerated Senator Manderson without application or examination and sent him a check for $\$ 4,300$. On learning that the rerating was irregular, the Senator refunded the money. New York Times, July 26, 1889. clviii.

House Ex. Doc., 51st Cong., 1st Sess., Report of Secretary of Interior, 
control over the Commissioner of Pensions and indicated an intention to deal in his own way with the cases of the rerated employes. On August 1 he was informed that he was "insubordinate to the last degree." Secretary Noble appointed a board to investigate the reratings in the Pension Office, and the conclusion was reached that an indefinite number of them involved a violation of the law and of the practice of the Department. It was thought to be impracticable to recover by litigation or otherwise the money that had been actually paid out. A number of the employes of the Pension Bureau who had been most directly concerned in rerating themselves were dismissed. ${ }^{2}$ Commissioner Tanner resigned, and, in accepting the resignation, President Harrison said: "It gives me pleasure to add that, so far as I am advised, your honesty has not at any time been called in question." $^{3}$ In October Green B. Raum was appointed Commissioner of Pensions. That he was a man of no high sense of official propriety appeared in the later investigations of the Pension Bureau under his administration."

1 House Ex. Doc., 51st Cong., 1st Sess., Report of Secretary of Interior, clxvii.

${ }^{2}$ House Ex. Doc., 51st Cong., 1st Sess., No. 360.

${ }^{3}$ New York Times, Scptember 13, 1889. Commissioner Tanner had made the mistake of undertaking to fuifl literally campaign pledges, regardless of the restrictions of pension law and practice. In an interview soon after he left the Pension Bureau, he said: "In fact, the only information I had about the result of their [the investigating board's] operations was when the Honorable Secretary himself, one day, when I was in his office, asked me if I knew what the commission said about the operations of the Pension Bureau. I told him I had not been favored in that respect in the slightest degree. He replied that they said I had granted more pensions and paid out more money in the same time than my distinguished predecessor did. I replied that I hoped to God that charge was true on the record, for I had plastered Indiana with promises last fall that that should be the fact if General Harrison came into power as President." New York Times, October 21, 1889.

4 House Reports, 52d Cong., 1st Sess., No. 1868. On Tanuary 6, 1890, Commissioner Raum issued an order making a change in the practice of the Pension Bureau affecting the adjudication of claims. This order had been sought by George E. Lemon, the leading Washington pension attorney, and would be highly advantageous to him. It had been previously refused. The next day after the order was issued $\mathrm{Mr}$. Lcmon endorsed a note for Commissioner Raum in the sum of $\$ 12,000$. Commissioner Raum was engaged in promoting and selling the stock of various corporate enterprises of a highly speculative character. The investigation of the Raum administration brought to light many facts and incidents that showed the low moral tone prevailing in the Pension Bureau. 
At the Milwaukee encampment of the G. A. R. late in August, 1889, the Pension Committee reported that they had prepared a "disability" bill without the requirement that disability be of service origin, and without a dependence clause. They had also prepared a service-pension bill granting a pension to each honorably discharged veteran at the monthly rate of one cent for each day's service in the Civil War, with a minimum pension of $\$ 8$ a month. These bills were both before Congress in the winter of $1888-1889$, but it was found impossible to get favorable action. In view of the "cordially friendly attitude of the Administration," the committee expressed great confidence that "before the conclusion of the next session of Congress legislation may be had which shall go far toward the completion of the full measure of the Nation's indebtedness to the men who defended her flag."' In their report, the committee also gave a review of their achievements since 1881 in securing pension legislation. Their confidence in future success proved to be well founded, and the first session of the new Congress saw finally the approval of a law establishing a pension system for Civil War soldiers based on a short term of service combined with the existence of disability not of service origin.

In his first annual message in December, 1889, President Harrison advocated the extension of the pension laws by the passage of a Dependent Pension Bill. ${ }^{2}$ He said:

The law now provides a pension for every soldier and sailor who was mustered into the service of the United

1 Journal of 23d National Encampment, G. A. R., 1889, 121-124. This encampment also passed the following resolution endorsing Commissioner of Pensions Tanner: "Resolved, That we thank the President of the United States for his appointment of our comrade, James Tanner, as Commissioner of Pensions, and that notwithstanding the assaults upon him, we declare our confidence in his integrity and our approval of his avowed purpose to do all that is possible to be done, under the laws of the land, for the veterans of the war; and with him we ask for the fullest investigation of the management of his office." This resolution was adopted as a substitute for extreme and outspoken resolutions condemning "in unmeasured terms the wicked and malignant criticism of our distinguished comrade." Comrade ranner asked that the resolutions first offered be withdrawn as "inopportune at this time." Ibid., 163-165.

2 Abridgment of Message and Documents, 1889-1890, 24. 
States during the Civil War and is now suffering from wounds or disease having an origin in the service and in the line of duty. Two of the three necessary facts, viz., muster and disability, are usually susceptible of easy proof; but the third, origin in the service, is often difficult, and in many deserving cases impossible to establish. . . . I am not unaware that the pension-roll already involves a very large annual expenditure, neither am I deterred by that fact from recommending that Congress grant a pension to such honorably discharged soldiers and sailors of the Civil War as having rendered substantial service during the war are now dependent upon their own labor for a maintenance, and by disease or casualty are incapacitated from earning it. Many of the men who would be included in this form of relief are now dependent upon public aid, and it does not, in my judgment, consist with the national honor that they shall continue to subsist upon the local relief given indiscriminately to paupers instead of upon the special and generous provision of the nation they served so gallantly and unselfishly.

This recommendation evidently contemplated such a measure as President Cleveland had vetoed-much less than was asked for by the G. A. R. Pension Committee, which was opposed to any requirement of dependence or indigence on the part of the soldier.

Many and varied pension bills were introduced into both Houses in the 51st Congress. The Senate gave the right of way to a Dependent Pension Bill introduced by Mr. Davis, which had the unanimous support of the Senate Committee on Pensions. ${ }^{1}$ Its principal provision granted a pension of $\$ 12$ a month to soldiers who served three months in the Civil War, were so disabled as to be incapable of supporting themselves, and were dependent on their daily labor, or on the contributions of others not legally bound thereto, for their support. It was in harmony with the recommendation in President Harrison's message. The estimated cost of the bill was $\$ 36,000,000$ annually. Efforts to strike out the "dependence clause" and to provide for graded

${ }^{1}$ Cong. Record, 51st Cong., 1st Sess., Part 2, 1796. 
disability rates of from $\$ 6$ to $\$ 12$ were defeated. Senator Plumb of Kansas offered an amendment to repeal the arrears limitation. He said that the cost of such a step was estimated at from $\$ 470$,000,000 to $\$ 500,000,000$, but that the government ought to recognize the claim regardless of cost. This amendment received only nine votes, but it is interesting to note that among them was that of John Sherman, ten years before one of the strongest opponents of the arrears bill. ${ }^{1}$ The Dependent Pension Bill, substantially in the form desired by the Senate Committee, passed the Senate March 31, 1890. ${ }^{2}$

In the House there was much sentiment for a service-pension bill instead of a dependent bill. This was in response to petitions and memorials that were coming in. On February 6, Mr. McKinley presented an appeal from Governor A. P. Hovey of Indiana, President of the Service Pension Association of the United States, and the resolutions of the Grand Army posts of forty states and four territories, for the passage of a servicepension bill, as recommended by the Grand Army of the Republic at the encampments at Columbus in 1888 and at Milwaukee in 1889. Now that the Republicans were in power, they wished to satisfy the ex-soldiers without going to extremes which would prove too costly. But the House was disposed to go farther than the Senate and pass service-pension legislation. Many Republicans maintained that their party was committed to such legislation. ${ }^{4}$

On April 7, Mr. Morrill of Kansas, for the House Committee on Invalid Pensions, attempted to get a two-thirds vote to suspend the rules, strike out all after the enacting clause of the

${ }^{1}$ Cong. Record, 51st Cong., 1st Sess., Part 3, 2840.

2 Ibid., 2846.

3 Ibid., Part 2, 1110-1115.

4 For instance, Mr. Joseph D. Taylor of Ohio said that General Hovey and President Harrison had carried Indiana in 1888 on the issue of servicepensions as compared with the Democratic promise of "dependent" pensions. Said Mr. Taylor: "Deny it if you wish, forget it if you can, but the fact remains that it was the position taken by the Republican party in the pension question that gave to that party the Presidency in 1888 and its present control of both Houses of Congress." Cong. Record, 51st Cong., 1st Sess., Part 5,4055 . 
Senate Dependent Pension Bill, and substitute a House bill which would give a service-pension of $\$ 8$ a month to soldiers who served ninety days in the Civil War and were 62 years old, and to those who were not 62 years old a pension of $\$ 8$ a month if they were disabled, without regard to dependence. ${ }^{1}$ It was estimated that this substitute would cost $\$ 40,000,000$ annually. After a partisan debate, the substitute failed to get a two-thirds vote (yeas, 169 ; nays, 87 ). ${ }^{2}$

On April 30, the Committee on Rules brought in a special rule for the consideration of Mr. Morrill's substitute for the Senate bill. ${ }^{3}$ Under this rule the bill was debated and passed, with an amendment reducing from 62 years to 60 years the age at which a soldier could receive the service-and-age pension. The final vote was 179 to 71 .

The Senate referred the House substitute for its whole bill to the Committee on Pensions, which made an extended report (No. 989) on the two measures, and recommended nonconcurrence and a conference. Conference committees labored over the disagreements between the two Houses for several weeks. The G. A. R. Pension Committee was granted a hearing by the conferees. ${ }^{4}$ Finally a compromise bill was agreed upon. ${ }^{5}$ The House permitted the service-and-age pension feature to be struck out. The Senate gave up the "dependence clause" and agreed to a graded rate of from $\$ 6$ to $\$ 12$ a month instead of a single rate of $\$ 12$. A small but very important change was the insertion of the word "manual" before the word labor in Section 2 of the bill. So far as soldiers were concerned, the Senate Dependent Pension Bill had been changed into a Disability Pension Bill. The bill, however, contained a provision for widows with

1 Cong. Record, 51 st Cong., 1st Sess., Part 3, 3115.

2 Ibid., Part 4, 3120. Illustrating the partisan character of the discussion, Mr. Henclerson of Iowa said: "We intend to tie every Democratic hand that has a dagger for the soldier in it. [Applause on Republican side.] This bill will give the boys $\$ 40,000.000$, and if not passed it will be by Democratic votes that it will be defeated." [Applause.]

3 Ibid., Part 4, 4026.

4 Journal of the 24th National Encampment, G. A. R., 1890, 168.

5 Cong. Record, 51 st Cong., 1st Sess., Part 6, 5944. 
the requirement of "dependence upon daily labor for support" retained. Mr. Morrill said in the House that the bill as agreed upon by the conferees would cost about $\$ 35,000,000$ per annum. In the Senate, Mr. Davis estimated the annual cost at about $\$ 41,000,000$. $^{1}$ He said that estimates regarding the cost of pension legislation were in their nature conjectural. "The grounds and confines of the whole question are conflicting, vague, shadowy." Senator Gorman thought that the bill might cost $\$ 79,000,000$ a year. Much partisanship was shown in the debate on the conference report in the Senate. Mr. Gorman charged that the Republicans had made pensions a party matter, and that the question had been "kicked around as a football on every stump in the land." However, the bill reported from conference passed both Houses easily and was signed by President Harrison on June $27,1890 .^{3}$

It has seemed worth while to describe the movement leading up to the passage of this law in considerable detail, for it established an entirely new system of pensions for Civil War soldiers and their dependents, and proved to be the most costly pension law ever enacted. Even the exacting G. A. R. Pension Committee was fairly well satisfied. They reported at the next encampment: "While not just what we asked, it is the most liberal pension measure ever passed by any legislative body in the world, and will place upon the rolls all of the survivors of the war whose conditions of health are not practically perfect." They said also that they had assurances "from the officers of the government, in whose hands is the administration of this law, that it is to be construed very liberally towards the veterans of the war."

1 Cong. Record, 51st Cong., 1st Sess., Part 6, 5969.

2 Ibid., Part 7, 6375-6377.

${ }^{3} U$. S. Statutes at Large, xxvi, 182-183.

4 Journal of the 24th National Encampment, G. A. R., 1890, 169. This encampment was held at Boston and was attended by President Harrison who was enthusiastically received as he reviewed the Grand Parade and participated in other events of the occasion. He said at one of the banquets: "It is not my purpose tonight to address you in extended speech, but only to say that, whether walking with you in the private pursuits of life or holding a place of official responsibility, I can never in either forget those who upheld the flag of this nation in those days when it was in peril." (Unofficial Pro- 
The Disability Pension Act of 1890 (as it should be called) was really a service-pension law subject to a limitation-the existence in applicants of disabilities, regardless of origin. ${ }^{1}$ The only requirements of a military character were service of ninety days or more during the Civil War and honorable discharge. So far as soldier applicants were concerned, the vital part of the act was Section 2. It provided :

That all persons who served ninety days or more in the military or naval service of the United States during the late war of the rebellion and who have been honorably discharged therefrom, and who are now or who may hereafter be suffering from a mental or physical disability of a permanent character, not the result of their own vicious habits, which incapacitates them from the performance of manuai labor in such a degree as to render them unable to earn a support, shall, upon making due proof of the fact according to such rules and regulations as the Secretary of the Interior may provide, be placed upon the list of invalid pensioners of the United States, and be entitled to receive a pension not exceeding twelve dollars per month, and not less than six dollars per month, proportioned to the degree of inability to earn a support; and such pension shall commence from the date of filing the application in the Pension Office after the passage of this act, upon proof that the disability then existed, and shall continue during the existence of the same.

Persons already pensioned under the general laws were permitted to apply under this act, and pensioners under this act might apply under the general law system. But no person could receive more than one pension covering the same period of time. It was

ceedings, 258.) The encampment passed resolutions unanimously thanking Congress "for the most liberal system of pension laws ever enacted" and thanking the President of the United States "for the evidence given of his sympathy with his comrades, by his prompt action in giving his cheerful approval to the disability bill, which has lately become a law." There was a strong sentiment in favor of discontinuing organized effort to secure a straight service-pension bill, and resolutions were offered to that effect. Comrade Governor Hovey of Indiana presented resolutions, saying: "We demand the passage of a service-pension bill." The advocates of servicepensions won by 174 to 160 . Journal, 254 .

1 Except that disabilities caused by vicious habits were not pensionable. 
expected that a large number of the pensioners already receiving small rates under the general law would find it possible to receive larger pensions under the act of 1890 , because under the latter law they could be rated for disabilities not of service origin.

The act of 1890 also extended to a new class of widows the benefits of the pension laws. Formerly the widow of a Civil War soldier could not obtain a pension unless she proved that her husband's death was the consequence of causes originating in the military service. After 1890 the widows of those who served ninety days or more in the Civil War and were honorably discharged were entitled to be pensioned at the rate of eight doilars per month without regard to the cause of the soldier's death, provided, however, that the widow applicant married the soldier before June 27, 1890, and that she was dependent upon her daily labor for support. The widow's rate of eight dollars a month compared with twelve dollars then being paid to those widows under the general law system, who had married the soldier prior to March 19, 1886. As was provided under the general law, so under the act of 1890 an additional allowance of two dollars per month was made for each child of the deceased soldier under the age of sixteen years. Remarriage terminated a widow's pension. In case of death or remarriage, the pension continued to be paid to any surviving children of the soldier until they reached the age of sixteen. When a minor child was insane, idiotic or otherwise permanently helpless, the act of 1890 continued the pension during life or during the period of disability. ${ }^{1}$

Attorneys' fees under the act of 1890 were limited to ten dollars.

As a pension law under which $\$ 60,000,000$ or $\$ 70,000,000$ a year was paid from the national Treasury for a long period of time, the act of 1890 seems to the writer to be open to many and grave objections.

\footnotetext{
1 Mention should also be made of an act of August 5, 1892, (United States Statutes at Large, xxvii, 348) granting service-pensions to the army nurses of the Civil War at the rate of twelve dollars a month. Nurses were eligible who had served six months, and had been honorably relieved from service, provided they were unable to earn a support.
} 
The only requirement of a military character exacted of the hundreds of thousands of beneficiaries under this act was a service of ninety days or more in the Civil War and honorable discharge. This placed the three months' man, who was perhaps never in battle or active service, on the same basis with the soldier who endured the risks and hardships of three or four long years of warfare. Where service gave the only color of claim to a pension, long, dangerous, and meritorious service received no superior consideration over brief and inactive service.

Under the act of 1890 pensions were granted to ex-soldiers for incapacity to perform manual labor in such a degree as to render them unable to earn a support. Rates of from six to twelve dollars a month were provided, proportioned to the degree of inability to earn a support. But a man might be in receipt of a comfortable or handsome income from his services as a skilled worker, salesman, clerk, lawyer, physician, public official, business man, or banker without thereby being ineligible for a pension. The law inquired only as to the ability of the applicant to perform crude manual labor, and rated in an arbitrary manner those physical and mental ills which, when of a permanent character, would hamper a man in performing such labor. For the favored class, the act of 1890 provided what was practically a species of paid-up insurance against bodily disability of a permanent character caused by accident or chronic disease. The premium was a service of ninety days or more during the Civil War. Pensions were provided for the highly paid but rheumatic lawyer, for the prosperous business man hurt in a street accident, for the ex-soldier public official with heart disease, and for the mechanic who had lost a hand in an industrial accident. It was well to have these ills of life provided for, but questionable whether military reasons required the provision to be made at the expense of the general taxpayer.

By reason of the striking out of the "dependence" clause, the act of 1890 made no distinction in granting pensions, so far as former soldiers were concerned, between those in affluent circumstances and the poor. Wealth, income, salary, ability to make 
a good living were ignored. The act was not a national gratuity or dignified form of relief for indigent and infirm veterans, as contemplated by the advocates of a Dependent Pension Bill, for it pensioned alike the rich and the poor, the prosperous and the unprosperous. It was not a reward for long and meritorious service in the army, for it treated the three months' man in exactly the same way as the soldier who fought through the whole war. It was not a compensation for injuries and disease contracted in the camp or on the battle-field, for it pensioned for mental and physical disabilities, whenever and wherever incurred, except those resulting from vicious habits. ${ }^{1}$ It was not even a national recognition of aged veterans in the closing years of life, like the Revolutionary, War of 1812, and Mexican War service-pension acts, for the men who were twenty-five years old in 1865 were only fifty in 1890 . Rather it was a measure calculated to bring about dependence on public aid and the simulation of bodily ills on the part of those who were in ordinary physical condition for their time of life and well able to care for themselves. There was every encouragement to the ex-soldiers to discover in themselves, and magnify, ailments which would have been little noticed but for the pension laws. In the words of the G. A. R. Pension Committee, the act of 1890 was calculated to place upon the pension rolls "all of the survivors of the war whose conditions of health are not practically perfect."

As for widows' pensions, the act of 1890 made it possible to grant military pensions, regardless of the cause of the husband's death, to widows who were unborn, or merely small children, when the Civil War ended. The law did originally limit these pensions to widows who were dependent upon their daily labor for support, but a later amendment established a more liberal rule. This provision especially benefited young women who, long years after the war, married middle aged or elderly exsoldiers. It is hard to see why such widows, and children born

1 See article, "A Costly Pension Law, Act of June 27, 1890," in South Atlantic Quarterly for October, 1904.

${ }^{2}$ Journal of the 24th National Encampment, G. A. R., 1890, 169. 
of such marriages, are more deserving of national aid than the dependent widows and children of other loyal citizens who were never called upon to perform military service. The experience of the Pension Bureau has also been that the desire on the part of young widows to retain pensions has frequently resulted in immoral alliances rather than in remarriages which would cause the loss of the pensions. ${ }^{1}$

The circumstances of the passage of the act of 1890 are not in its favor. It was not enacted solely-hardly principally-on its merits as a pension measure. It was the high bid for the political support of the $450,000 \mathrm{G}$. A. R. men ${ }^{2}$ and other ex-soldiers, with both the Republican and the Democratic parties bidding. To the professional politician it was a way to spend the surplus which appealed to the sentiment of the people and which also promised to produce votes for the candidates of the party. Undoubtedly, in passing the act of 1890, the Republican Congress and national administration attached strongly to that party the great majority of the G. A. R. voters. While the G. A. R remained avowedly non-partisan, it was generally conceded that Democrats were rather scarce in the organization.

Before it was largely superseded in 1907 , the act of 1890 cost the country over $\$ 1,000,000,000$, as shown by the table on page 270. This amount was raised by customs and internal revenue taxation upon all the people of all sections of the country and paid out to the favored class. The propriety of this use of the power of taxation to redistribute wealth depends upon the justification of the act of 1890 as a military pension law. If it was unsound in principle, extravagant in cost, poorly guarded in administration, a leading method of distributing surplus for political effect, then it was an imposition upon the taxpayers of the country. To a great extent the necessities and comforts of the

1 Under the general law pension system, if the widow can trace the cause which finally brought about her husband's death back to an origin in his army service, she can obtain a pension without regard to the date of her marriage. In extreme cases this has brought about marriages of young women to aged veterans whom death was just about to claim.

2 Journal of the 24th National Encampment, G. A. R., 1890, 19. 
poor were taxed, and the resulting funds paid out in gratuities to persons who were better off than a large proportion of the taxpayers. After a quarter of a century had elapsed since the close of the Civil War, the act of 1890 operated to distribute hundreds of millions of dollars, raised from the taxation of the whole country, almost exclusively in the sections and states from which the Union armies were recruited. Upon the reasonableness and propriety of the act as a pension measure depends the justice of such a distribution.

The system of Civil War pensions established by the act of 1890 left the basis of the ratings from $\$ 6$ to $\$ 12$ a month to be determined by the Pension Bureau. This matter was the subject of much controversy. ${ }^{1}$ Under Commissioner of Pensions Raum, who was pledged to a very liberal administration of the law, an order was issued (Order No. 164) on October 15, 1890, providing that pensioners under the act of 1890 who had disabilities which under the general law system would be rated at or above $\$ 6$ and less than $\$ 12$ should receive the same rates as though their disabilities were of service origin. If pensioners under the act of 1890 had disabilities which would be rated at or above $\$ 12$ a month, if of service origin, then they were to receive $\$ 12$ a month. This method of rating was highly advantageous to persons with minor disabilities not of service origin. For instance, a man who had a permanently stiffened (anchylosis of) wrist would get $\$ 8$ a month-the same rate as under the general law-while a person who was totally blind (from causes not of service origin) could receive oniy $\$ 12$ a month.

Under the Raum administration, claimants were also permitted to combine various small and nominal ratings for slight disabilities and thus to make up an aggregate that would entitle to a pension. For instance, a claimant might combine a $\$ 4$ rating for rheumatism, a $\$ 2$ rating for nasal catarrh, and a $\$ 2$ rating for the loss of a little finger, and by reason of the aggregate of the disabilities receive an $\$ 8$ a month pension. However, this

1 An extended discussion of the subject is contained in the report of the Commissioner of Pensions for 1899. 
practice of combining small rates under the act of 1890 was disapproved by the Department of the Interior in January, 1893. It was then held that in the aggregate such small disabilities might not disable a person for the performance of manual labor to a much greater degree than any one of them existing alone.

In President Cleveland's second administration, the Department of the Interior and the Bureau of Pensions under Commissioner Lochren interpreted the act of 1890 in a much more restricted way. Commissioner Raum's Order No. 164 was abrogated. It was held that disabilities under the act of 1890 were on an entirely different footing from disabilities of service origin under the general law system. Different systems of rating were adopted, the system under the act of 1890 taking into consideration "cases where incapacity to labor joins with incapacity to earn a support," and making the rates depend on these two conditions. Specific injuries or ailments were no longer given specific ratings but were considered only as they affected the capacity of a man to perform manual labor. A board of revision was put to work examining the claims allowed under Order No. 164 in the Raum administration. In his report for 1894, Commissioner Lochren said that 2,266 cases had been dropped and 3,343 reduced to lower ratings. He said that pensioners were not disturbed unless the allowance was clearly wrong or illegal. Commissioner Lochren was also active in reducing excessive ratings under the general law system, and was engaged in litigation in which his right to reduce pensions erroneously or illegally rated was sustained. ${ }^{1}$

1 An important case was that of Charles D. Long, one of the judges of the Supreme Court of Michigan. Judge Long was one of the pensioners rerated by Commissioner Tanner in 1889. He had lost his left arm above the elbow and suffered a gunshot wound of the left hip. For many years he had been pensioned at $\$ 72$ per month for total and permanent helplessness. Finding him to be a man of apparent vigor, discharging his duties on the bench of the Supreme Court of Michigan, Commissioner Lochren notified him to show cause why his pension should not be reduced to $\$ 50 \mathrm{a}$ month. The pensioner fought the reduction in the courts. Finally the Court of Appeals of the District of Columbia decided in favor of the power of Commissioner Lochren to reduce the pension, in an opinion filed June 6, 1895. This was an important test case in view of the Commissioner's activity in reducing improperly rated pensions. 
The work of readjudicating the pensions allowed under Order No. 164 in the liberal Raum administration of the Pension Bureau was carried on in 1893,1894, and 1895. The stopping and reducing of pensions made the administration of Commissioner Lochren very unpopular in G. A. R. circles. But it was a relief to the Treasury to have some check put upon the expansion of pension expenditures at a time of financial stringency. ${ }^{1}$

In the McKinley administration, H. Clay Evans of Tennessee became Commissioner of Pensions. The revision of the claims allowed under the rulings of Commissioner Raum was not continued. In his report for 1899, Commissioner Evans says of the practice of the Pension Bureau in administering the act of 1890 :

The Department's interpretation of the law has been that under said act pension is provided only in cases where incapacity to labor joins with incapacity to earn a support. I am free to say that the practice has never been to inquire into the capacity of the claimant to earn a support. The prosperous have been pensioned alike, on application, with the less fortunate, plainly on showing disabilities or disease, without any reference to the claimant's wealth or capacity to earn a support.

The second section of the act of June 27, 1890, is.by many understood to provide for a dependent pension. This is not the case; it pensions only for disability not necessarily of service origin. Disabilities for which pension is asked may have originated prior to the claimant's service, during his service, or since service, while engaged in the ordinary avocations of life. It matters not whether the claimant be in a condition of poverty or a millionaire; he must show by medical evidence that he has a physical or mental disability that disqualifies him in whole or in part for earning a support by manual labor.

Thus the two separate and distinct systems of pensioning (both for disability alone), one for disability of service

1 In Cleveland's second administration the total of deficits for the fiscal years $1894,1895,1896$, and 1897 amounted to $\$ 155,864,000$. The expenditures under the act of June 27,1890 , for the same years amounted to $\$ 237,087,000$. 
origin, the other for disability regardless of origin, afford a wide field for comparison and misunderstanding.

In the same report Commissioner Evans gave examples of the actual rates being paid under the two systems. Under the general law system the following were among the rates paid: disability equivalent to loss of hand or foot, $\$ 24$; incapacity to perform any manual labor, $\$ 30$; total deafness of both ears, $\$ 30$; loss of one eye, $\$ 17$; severe deafness of both ears, $\$ 22$; anchylosis of elbow, $\$ 10$. The same disabilities were pensioned under the act of 1890 at the following monthly rates: disability equivalent to loss of hand or foot, $\$ 10$; incapacity to perform any manual labor, $\$ 12$; total deafness of both ears, $\$ 12$; loss of one eye, $\$ 6$; severe deafness of both ears, $\$ 6$; anchylosis of elbow, $\$ 6$. But, under the act of 1890 , a most serious disability such as total blindness could not entitle to more than the maximum rate of $\$ 12$ a month. Total blindness of service origin was at that time pensioned under the general law system at $\$ 72$ per month.

During the administration of Commissioner Evans there was much pressure to make the administration of the act of 1890 more "liberal." Pensioners who had been dropped by Commissioner Lochren wished to be restored to the roll, and others whose pensions had been reduced were applicants for increase. In the presidential campaign year of 1900 , an act became law on May 9 which made important amendments to the act of $1890 .^{1}$ One of these amendments provided that in fixing the ratings of pensioners "each and every infirmity shall be duly considered and the aggregate of the disabilities shown be rated." What those who proposed this amendment probably had in mind was the authorization by law of one of the practices that prevailed during the Raum administration of the Pension Bureau, the rating of slight disabilities shown by applicants under the act of 1890 at arbitrary fractions of total, and adding two or more of these fractions to determine the proportion of the maximum rate to be paid. Commissioner Evans, however, placed upon this

1 U. S. Statutes at Large, $\mathrm{xxxi}, 170$. 
amendment an interpretation which was not pleasing to the G. A. R. and caused many protests to be made. He issued instructions on June 30,1900 , that examining surgeons in determining ratings under the act of 1890 should give due consideration to each and every infirmity, and rate "the degree or extent to which all of these infirmities, whether minor or serious, when considered together, render the claimant unable to earn a support by manual labor." The result was to be stated as $\$ 6, \$ 8$, $\$ 10$, or $\$ 12$ per month, nor was there to be a separate rating of separate disabilities as before. ${ }^{1}$ This ruling was in the interest of substantial justice but was far from satisfactory to those who drafted the amendment.

It is to be noted that at this time it was the practice of the Pension Bureau to consider age an important factor in fixing the rate under the act of 1890 , although the law itself makes no mention of age. Commissioner Evans instructed the examining surgeons: "A claimant who has reached the age of 75 years is allowed the maximum rate for senility alone, even where there are no special pensionable disabilities. A claimant who has attained the age of 65 years is allowed at least the minimum rate, unless he appears to have unusual vigor and ability for the performance of manual labor in one of that age. The effect of partial senility should be considered with other infirmities, where there are such, and the aggregate incapacity stated." Thus it will be seen that the Pension Bureau administered the act of 1890 to a certain extent as a service-and-age pension law. There was already a tendency to extend the system in that direction.

Another important amendment in the act of May 9, 1900, affected the pensions of widows. The original act of 1890 provided for pensioning widows who were without means of support other than their daily labor. But the Pension Bureau had construed this provision with considerable latitude and had in practice allowed widows to have a small income without barring them from receiving a pension. The amount of income per-

${ }^{1}$ Report of the Commissioner of Pensions for 1900. 
mitted had, however, varied widely under different administrations of the Pension Office, and even at different periods in the same administration. Consequently there had been much complaint and criticism. Under the Evans administration, if the wiclow's income, aside from her daily labor, did not exceed annually what her pension would be, $\$ 96$, she was deemed to be without other means of support than her daily labor, and was allowed a pension. The Grand Army of the Republic at its encampment in 1899 asked for a more liberal rule, and President McKinley in his annual message of that year, adopting a suggestion of the Commissioner of Pensions, recommended that widows be permitted to have pensionable status under the act of 1890 when the amount of income independent of the proceeds of daily labor was not in excess of $\$ 250$ a year. The legislation of 1900 included this provision.

The act of 1900 had been passed to give to the act of 1890 liberal constructions which Commissioner Evans had refused to sanction without authority of law. ${ }^{1}$ At the national encampment in August, 1900, the Pension Committee of the G. A. R. reported that they had practically determined the wording of the act of 1900 , but they expressed great dissatisfaction with the way in which the Secretary of the Interior and Commissioner Evans had construed the section providing for the aggregating of disabilities. What the G. A. R. men wanted was a restoration of the practice prevailing, under Order No. 164, in the Raum administration of the Pension Bureau. At the national encampment of 1901 Commissioner Evans was again charged

1 When Mr. Evans was appointed Commissioner of Pensions in 1897, the G. A. R. Committee on Pensions pronounced him "the right man for the right place." Although he was a Union veteran, he did not prove as "liberal" as had been expected. Desired changes in the practice of the Pension Bureau were refused. Mr. Evans was disposed to protect the government from imposition either by means of loose interpretations of the laws or by outright frauds. He was vigorous and outspoken in his views. At the G. A. R. encampment in 1898, Corporal Tanner, ex-Commissioner of Pensions and attorney prosecuting claims against the government, denounced the conduct of the Pension Bureau under Mr. Evans. The attack on the Evans administration was continued at the national encampment of 1899 , and it was suggested that an appeal be made to the President, and, if necessary, to Congress. This appeal brought about the act of May 9, 1900. 
with circumventing the provisions of the act of 1900 , and it was decided to take the complaints against him to the President. General Daniel E. Sickles, a member of the Committee on Pensions who was extremely hostile to the administration of the Pension Bureau, said with regard to Commissioner Evans's alleged policy of saving: "That policy is born and reared in the Pension Bureau, it is conceived in a desire to turn money back into the Treasury that belongs to you and me, my comrades, a policy born of a cringing desire to serve taxpayers and earn newspaper applause by reducing expenditures, a mean, stingy, grinding policy, unworthy of a great and generous government and a noble and grateful people."

Despite the pronounced G. A. R. hostility to Commissioner Evans, he was not displaced by President McKinley. After Mr. McKinley's death in 1901, the complaints against the Commissioner were taken to President Roosevelt. In 1902 Commanderin-Chief Torrance and the Committee on Pensions of the G. A. R. held extended sessions in Washington investigating the conduct of the Pension Bureau. In their report they declared that "among the survivors of the War of the Rebellion there is an irremovable belief and conviction that the present Commissioner of Pensions is not disposed to administer the duties of his office in that spirit of equity and justice to applicants for pensions which they have a right to expect, and while we are actuated by no feeling of unkindness toward the Honorable Commissioner of Pensions, we are convinced that justice to the soldier is impossible of attainment under the present administration of the Pension Bureau. ${ }^{\text {"1 }}$ At the national encampment at Washington in October, 1902, Commander-in-Chief Torrance said that the report of the investigation of the Pension Bureau had been placed in the hands of the President, and "the acceptance of the resignation of the Commissioner of Pensions immediately followed."2 However, Mr. Evans was promptly appointed consul

1 Journal of the 35th National Encampment, G. A. R., 1901, 198.

2 Journal of the 36th National Encampment, G. A. R., 1902, 301 to 308.

3 Ibid., 128-129. 
general at London at a largely increased compensation. President Roosevelt substituted as Commissioner of Pensions Eugene F. Ware of Kansas, a lawyer and poet. ${ }^{1}$

After its success in bringing about the retirement of $\mathrm{Mr}$. Evans, one of the strongest and ablest of the Commissioners of Pensions, the Grand Army, at the national encampment in 1903, again took up the matter of securing the enactment of a service-pension law. The encampment instructed the Committee on Pensions to present to Congress a bill providing that a pension of twelve dollars a month should be paid to every honorably discharged survivor of the war who served ninety days and who had passed the age of 62 years, and also providing that widows' pensions under the act of 1890 should be increased to twelve dollars a month. ${ }^{2}$ In the early months of 1904 , the committee met in Washington to work for the desired servicepension measure. Thousands of Grand Army posts petitioned Congress for its passage. It was again the year of a presidential campaign, and something had to be done for the veterans. But the Department of the Interior and the Commissioner of Pensions estimated that the proposed law would call for expenditures beyond the ability of the Treasury to pay. In this situation, the Roosevelt administration granted the veterans a part of what they desired by the issuance of Order No. 78 from the Bureau of Pensions to take effect April 13, 1904. ${ }^{3}$

Order No. 78 was a broadening of the terms of the act of June 27, 1890, by the process of executive construction. The order declared that old age was an infirmity the average nature and extent of which the experience of the Pension Bureau had

1 Commissioner Ware was a great believer in the sentimental side of the pension question. The consideration that a pension was an equivalent for disability was "the hard, pig iron side" of the question; the sentimental side was that old soldiers should not go to the poor-house, whether they had been shot to pieces or not, or whether they had been improvident or not. He also took into consideration the necessity of having votes for his party in order that it might perform its good work in the community.

2 Journal of the 37th National Encampment, G. A. R., 1903, 169.

3 Journal of the 38th National Encampment, G. A. R., 1904, 59-63, 161-165. Also see Report of the Commissioner of Pensions for 1904. 
established with reasonable certainty. It therefore provided that in the adjudication of claims under the act of 1890, as amended, "it shall be taken and considered as an evidential fact, if the contrary does not appear, and if all other legal requirements are properly met, that, when a claimant has passed the age of sixtytwo years he is disabled one-half in ability to perform manual labor and is entitled to be rated at six dollars a month; after sixty-five years at eight dollars a month; after sixty-eight years at ten dollars a month, and after seventy years at twelve dollars a month." The instructions accompanying this order provided that "a declaration, stating that a claimant is sixty-two, sixtyfive, sixty-eight, or seventy years of age, as the case may be, is a sufficient allegation, even if no other disabling cause is set forth." Thus the interposition of the executive power converted the act of 1890 into a service-and-age pension law similar to the Mexican War act of January 29, $1887 .{ }^{1}$

In the presidential campaign of 1904, critics of President Roosevelt pronounced the issuance of Order No. 78 an act of executive usurpation of the function of the legislature. In an attempt to justify the order, it was preceded by a number of "whereases" referring to the action of Congress in 1887 granting service-and-age pensions to the Mexican War soldiers. But there is no good reason to believe that Congress intended the act of June 27, 1890, and amendments to be construed as a simple service-and-age pension law. In fact it has been shown on a previous page that, when the act of 1890 was passed, the House of Representatives favored a service-and-age pension act but was compelled to give up its contention because of the opposition of the Senate. The service-and-age proposition was defeated.

Under Order No. 78 survivors of the Civil War who served ninety days and had reached the required ages were pensioned without having to prove any disability, and regardless of wealth,

1 Under Order No. 78, between April 13, 1904, and June 30,1909, there were 24,625 original allowances of pensions and 84,296 increases. The annual value of all these pensions and increases was about $\$ 4,775,000$. Order No. 78 was substantially superseded by the act of February 6,1907. Report of the Commissioner of Pensions for 1909, 13. 
income, or ability to provide for their own support. Everyone was eligible who could show ninety days' service, honorable discharge, and the required age. Reasons of political expediency and the desire to forestall possible expensive service-pension legislation caused the order to be issued, but it is questionable whether they warranted or justified so sweeping an example of legislation through executive construction.

While the issuance of Order No. 78, to take effect April 13, 1904, gained the favor of the G. A. R. members for his administration, President Roosevelt took care of one of the favorite leaders of the Grand Army by appointing to the office of register of wills in the District of Columbia, April 1, 1904, Corporal James Tanner, who had been ousted from the office of Commissioner of Pensions during the administration of President Harrison and who had since been engaged in prosecuting claims against the government. At the 1905 national encampment, Corporal Tanner was elected commander-in-chief of the G. A. R. for the ensuing year.

At the national encampment of 1904, Commander-in-Chief John C. Black, formerly Commissioner of Pensions in the first Cleveland administration, recommended that the G. A. R. make earnest efforts "to crystallize the beneficent provisions of Order No. 78 into statute law" in order that the whole matter might be placed beyond the reach of interpretation or change of views. The Committee on Pensions recommended that their successors continue work for the service-pension bill which had failed to pass in 1904 because it was thought to be too expensive. ${ }^{1}$ At the 1905 encampment, the Committee on Pensions reported that owing to the Treasury deficit and the short session of Congress nothing had been accomplished toward securing the passage of the G. A. R. service-pension law. They had been assured, however, that favorable action would be taken in the 59th Congress. The service-pension bill was again endorsed. ${ }^{2}$

The principle affirmed in Order No. 78, that the age of sixty-

1 Journal of the 38th National Encampment, G. A. R., 1904, 59-63, 161-165.

2 Journal of the 39th National Encampment, G. A. R., 1905, 281-283. 
two years or over was a pensionable disability, was made statutory law by provisions in acts of April 24, 1906, and March 4, $1907 .{ }^{1}$ It was left to the discretion of the Pension Bureau to fix the rates for particular ages and cases. The G. A. R. at the national encampment of 1906 again asked for the enactment of its proposed service-pension law. Members were urged to put Senators and Representatives on record in the matter. ${ }^{2}$ Financial conditions were changing, and it could no longer be objected that new pension legislation was beyond the means of the Treasury. While there was a deficit of $\$ 18,750,000$ in 1905 , the excess of ordinary receipts over expenditures was $\$ 45,300,000$ in 1906 and $\$ 111,400,000$ in $1907 .{ }^{3}$ Under such circumstances, a bill for service-and-age pensions, which had been introduced by Senator McCumber, Chairman of the Senate Committee on Pensions, was pressed to its passage. The cost of this measure was estimated at from $\$ 10,000,000$ to $\$ 15,000,000$ annually. Again expression was given to the idea that the old soldiers had a preferred claim on any surplus that might accumulate in the Treasury. In advocating the bill, Mr. McCumber said in the Senate on January 9, 1907 :

The country now, Mr. President, is wealthy. The Treasury is bursting with its load of coin. Under these conditions extravagances of every character are creeping into our legislation, extravagances which well might be abandoned until we have performed our entire duty toward the survivors of that war which made it possible that we have a country of this wealth and which could indulge in those extravagances. ${ }^{4}$

Before the McCumber bill passed the Senate, it was amended to include Mexican War veterans in the benefits of its provisions. In the House the bill was reported favorably from committee, taken up under a suspension of the rules, and passed

$1 U$. S. Statutes at Large, xxxiv, 133, 1406.

2 Journal of 4oth National Encampment, G. A. R., 1906, 135-136, 179.

${ }^{3}$ Statistical Abstract of the United States, 1915, 659.

4 Cong. Record, 59th Cong., 2d Sess., 805. 
without amendment. ${ }^{1}$ It was signed by the President February 6, 1907.2 This law provided in brief that any person who served ninety days or more during the Civil War or sixty days in tile war with Mexico, was honorably discharged, and had reached the age of sixty-two years or over, should be placed upon the pension roll and receive a pension as follows: at the age of sixty-two years, $\$ 12$ per month; at seventy years, $\$ 15$ per month; at seventy-five years, $\$ 20$ per month. The pensions were to commence from the date of filing the application after the passage and approval of the act. Persons who applied and received pensions under this act were not permitted to receive pensions for the same period under any other general or special law.

Most of the Civil War soldiers pensioned under the act of June 27,1890 , were gradually transferred to the roll under the act of February 6, 1907, in order to get the advantage of higher rates. From the passage of the latter act until June 30, 1909, there were 444,411 certificates issued under its provisions. Of these pension certificates, only 16,324 were issued to persons not already on the pension roll.

At the national encampment of the G. A. R. in September, 1907, the Committee on Pensions reported that in conference with the Speaker of the House, the House Committees on Pensions and Invalid Pensions, and President Roosevelt, it had supported the McCumber bill unamended. But it recommended that a fight be made for an increase in widows' pensions. Commander-in-Chief Brown in his annual address spoke of the success of the G. A. R. in establishing the principle that advanced age constituted a well defined disability. He advocated a continuance of the movement to have widows' pensions increased to twelve dollars a month. With reference to the attitude of the President toward the claims of the ex-soldiers, he said: "President Roosevelt is the friend of the veteran soldiers and sailors

${ }^{1}$ Cong. Record, 59th Cong., 2d Sess., 2218-2222.

$2 U$.S. Statutes at Large, xxxiv, 879.

3 Report of the Commissioner of Pensions for 1909, 14. 
of the republic. Official acts, public declarations, and assurances in private conferences warrant the statement that no Chief Executive in the history of the Nation has held or could hold in higher regard the services of the men who saved this Union, and no President has evinced a stronger desire to adequately recognize that service and its results than Theodore Roosevelt."1

During the next year the commander-in-chief and Committee on Pensions of the G. A. R. were principally occupied with working for the passage of a widows' pension bill. ${ }^{2}$ 'The pensions of veterans had been increased by the act of 1907 , and, from a political standpoint, 1908 was a good year in which to ask Congress and the Executive for more liberal pensions for widows. Success came to the G. A. R. men in the passage of the act of April 19, 1908..$^{3}$ In all cases where widows were entitled to receive a less rate, this law increased their pensions to twelve dollars a month. Thus it applied to those general law widows, married after March 19, 1886, who were receiving only eight dollars a month. But the most important effect of the act of 1908 was to grant pensions at the rate of twelve dollars per month to the widows of persons who served ninety days or more in the army or navy of the United States during the Civil War and were honorably discharged, zeithout regard to the pecuniary condition of the widow's, provided they were married prior to June 27, 1890. While the pension rate was increased from eight to twelve dollars a month, the conditions of title were the same as under the act of 1890 , except that all requirements as to dependence were eliminated. Because of its greater liberality in rate and conditions, the act of 1908 promptly superseded the act of 1890 so far as widows' claims were concerned.

The two acts of February 6, 1907, and April 19, 1908, caused a large increase in federal pension expenditures. From \$138,155,000 in the fiscal year 1907 , the amount paid as pensions in-

1 Journal of the 4Ist National Encampment, G. A. R., 1907, 74-76, 78, 248-250.

2 Journal of 42d National Encampment, G. A. R., 1908, 90-93, 214-215.

3 U. S. Statutes at Large, $\mathrm{xxxv}, 64$. 
creased to $\$ 153,093,000$ in 1908 and $\$ 161,974,000$ in 1909 - the disbursement in 1909 being the largest in any single year up to that time. The pensions of 202,577 widows and minor children, on the roll when the act of April 19, 1908, was passed, were immediately increased by the amount of forty-eight dollars a year without requiring the pensioners to make application. There were also a large number of new applications under the act of 1908 , due to the elimination of all conditions concerning the pecuniary circumstances of widows. Between April 19, 1908, and July 1, 1909, there were 31,394 pension certificates issued under the new law. ${ }^{1}$ Thus by the fiscal year 1909, the system of Civil War pensions inaugurated by the act of June 27, 1890, had been so amended and expanded that it required the expenditure of $\$ 105,888,000$ - this amount being paid on claims in which there was no connection established between the disability or death and military service. In the same fiscal year, $\$ 46,900,000$ was paid out in Civil War pensions under the general law which required proof that the cause of the disability or death originated in military service. The service-pension system now overshadowed the general law system.

Before its conditions and rates were made more liberal by the acts of February 6, 1907, and April 19, 1908, the cost of pensions under the act of June 27,1890, had already reached a total considerably in excess of $\$ 1,000,000,000$. For the year 1906, before the new legislation, the expenditures under the act of 1890 amounted to a total of $\$ 74,000,000$. In 1909 , after the acts of 1907 and 1908 were in full operation, the combined cost of executing the acts of 1890,1907, and 1908 amounted to $\$ 105,888,000 .^{2}$ Thus the annual expenditure for Civil War service-pensions was increased nearly $\$ 32,000,000$. This added pension expenditure fell in a period of deficient government receipts following the panic of 1907 . There was a deficit of $\$ 20$,000,000 in 1908 and $\$ 58,700,000$ in 1909 . The corporation income tax included in the tariff act of 1909 produced an annual

1 Report of the Commissioner of Pensions for 1909, 9, 10, 13, 15.

2 Ibid. for 1906 and 1909. 
amount about equal to the increase in pension expenditures: $\$ 20,952,000$ in $1910 ; \$ 33,517,000$ in 1911 ; and $\$ 28,583,000$ in 1912. ${ }^{1}$

The laws of 1907 and 1908 did not long content the servicepensioners. The desire of many of the veterans was to secure a pension of a dollar a day, and bills having that end in view were put forward. Others asked for higher rates at the various ages named in the act of 1907 , or for the maximum rate of twenty dollars at a much earlier age. On behalf of widows, measures were advocated for the pensioning of widows who married ex-soldiers after June 27, 1890. The national encampment of the G. A. R. at Salt Lake City in 1909 disapproved the dollara-day pension proposal as impractical, but endorsed the movement to extend the date previous to which the marriage of pensionable widows must have taken place. ${ }^{2}$ At the 1910 encampment the commander-in-chief reported that practically no general pension legislation had been secured in the past year because of a deficiency in the revenues. At this meeting there was a majority report of the committee on resolutions in favor of a bill increasing the rates of the act of February 6, 1907, and a minority report in favor of the dollar-a-day pension project. The majority. report, which was adopted, favored increasing the rates of the act of 1907 as follows: at sixty-two years of age, $\$ 12$ a month; at sixty-six years, $\$ 15$; at seventy years, $\$ 20$; at seventy-five years, $\$ 25$, and to those who were entirely incapacitated physically, $\$ 300^{3}$

During the winter of $1910-11$, the G. A. R. Committee on Pensions worked for the bill which was endorsed by the national encampment, but they reported failure at the Rochester encampment next August because part of the G. A. R. men had given their support to other bills much more costly than the endorsed

1 Statistical Abstract of the United States for 1915, 625, 659.

2 Journal of the 43d National Encampment, G. A. R., 1909, 86-87, 188-191, 250-251.

3 Journal of the 44th National Encampment, G. A. R., 1910, 70, 237, 307-310. 
measure. ${ }^{1}$ The committee complained that posts which had favored measures involving too great an expenditure had deprived the encampment bill of the united support which might have secured for it favorable consideration."

A service-pension bill which had gained strong support was that prepared and advocated by General Isaac R. Sherwood, a Democratic representative from Ohio, who was a G. A. R. man and had served long and gallantly during the Civil War. General Sherwood advocated liberal service-pensions graded according to the length of service rendered by the pensioner. He was the Chairman of the Committee on Invalid Pensions in the Democratic House of Representatives of the 62d Congress (1911-1913), and hence he was in a position to command attention for his views. The Sherwood bill disregarded age in determining the rate of pensions. It proposed to grant to Civil War veterans who had served from ninety days to six months a service-pension of $\$ 15$ a month; from six months to nine months, $\$ 20$; from nine months to one year, $\$ 25$; one year or more, $\$ 30$. Thus, under this bill, all who had served one year or more would receive about a dollar a day as a pension. Since over seventy per cent of the Civil War survivors had a service of one year or more, General Sherwood's bill was obviously likely to be very expensive. ${ }^{3}$

The respective merits of the Sherwood bill, the Sulloway bill, and the service-and-age measure which had been endorsed by the G. A. R. were discussed at the national encampment of 1911. The Committee on Pensions reported that the G. A. R. would have to reckon with the principle of the Sherwood bill." Sentiment gradually came to favor a compromise measure grading the pensions both according to age and length of service.

The fiscal years 1911 and 1912 found the Treasury again in

1 The Sulloway bill, a service-and-age pension bill with more liberal rates than the official G. A. R. bill, passed the House of Representatives, but did not come to a vote in the Senate.

2 Journal of the 45th National Encampment, G. A. R., 1911, 216-220.

${ }^{3}$ Report of the Commissioner of Pensions for 1912, 22-23.

4 Journal of the 45th National Encampment, G. A. R., 1911, 254-259. 
prosperous condition, and a presidential campaign was approaching. These two circumstances were highly favorable to the success of the movement for new and more liberal pension legislation. Neither party cared to stand against the wishes of the veterans. The only question was how much to give them. Mr. Sherwood had introduced his bill in the House at the first session of the 62d Congress on April 4, 1911. On August 19, 1911, just before the Grand Army national encampment, the measure was reported from committee by Mr. Sherwood, read thle first and second times, referred to the Conmittee of the Whole House on the State of the Union, and ordered printed, ${ }^{1}$ Mr. Sherwood attended the G. A. R. encampment and heard the discussion as to the sort of pension bill desired by the ex-soldiers. At the second session in December, Mr. Sherwood's bill was taken up in the House, and he made a speech in which he described the proceedings at the G. A. R. encampment. ${ }^{2}$ He said that it was intended by some persons to run the encampment as a political machine, to elect John McElroy, editor of the National Tribune, as commander-in-chief, and to get the veterans in line for the Sulloway bill and the Republican party. General Sherwood said: "I was not the only Democrat in the encampment, although I was about the only one." The plan of McElroy and his friends proved "too raw," and General Sherwood claimed that the prevailing sentiment at the encampment was for the Sherwood bill in preference to the Sulloway bill or the national encampment bill. The only vote taken on the subject was ambiguous in character.

The whole debate on the Sherwood bill in the House of Representatives illustrated the extremely political character of the pension question. Both the Sherwood bill (proposed by a Democrat) and the Sulloway bill (proposed by a Republican) carried far greater increases in pensions than had been asked for by the Grand Army of the Republic at its national encampment at At-

1 Cong. Record, 62d Cong., 1st Sess., 4243.

2 Ibid., 2d Sess., Part 1, 127-128. See also Journal of 45th National Encampment, G. A. R., 1911, 251, 254-259. 
lantic City in 1910. On the basis of the number of pensioners on the roll June 30,1910, the estimated increase of pensions for one year under the Sherwood bill was over $\$ 75,000,000$ and under the Sulloway bill over $\$ 45,000,000$. Although the high mortality among the old soldiers had considerably reduced the amounts necessary by December, 1911, the cost of either bill would be very large. But no proposal appeared to be too expensive for the majority of the members. Leaders of both parties vied with each other in professions of what they were willing to do for the old soldiers. General Sherwood twitted the Republicans with their failure to enact the Sulloway bill, which had passed the House of Representatives when they were in power. He intimated that its failure to come to a vote in the Senate was due to President Taft's opposition and the fear of his veto.

Speaking of the way endorsements of the Sulloway bill had been secured from state legislatures, General Sherwood said: "You can get anyone to vote for any pension bill you want in any legislature in the North, because the members do not dare to vote against it."1 Representative Martin Dies of Texas had substantially the same opinion as to the courage of the House of Representatives. In one of the few speeches opposing the Sherwood bill, he said: "I am a party Democrat and I want my party to win, but the naked truth is that the Democratic party is just as cowardly on this pension question as ever the Republican party dared to be." Mr. Dies considered that the proposed pension increase was a contribution to the ex-soldiers for political purposes and that it would be an obstacle to tariff reduction. "Every man," said he, "who votes for this pension increase indirectly votes against lower tariff taxation." Some Democrats replied that the pension increase could be defrayed by the economies of Democratic administration or by levying an income tax.

Finally the House of Representatives passed the Sherwood bill, December 12, 1911, by 229 to 93 , the opposition consisting

${ }^{1}$ Cong. Record, 62d Cong., 2d Sess., Part 1, 127. 
principally of southern Democrats. ${ }^{1}$ Former Speaker Cannon, Mr. Mann, Mr. Sulloway, and the Republicans generally joined with Speaker Clark, Mr. Sherwood, and most of the northern Democrats in supporting the measure. ${ }^{2}$

In January following the passage of the Sherwood bill by the House, Senator McCumber, chairman of the Committee on Pensions in the Republican Senate, introduced a service-and-age bill. This measure was modified in committee by grading the pensions according to length of service as well as age, and, on February 14, Mr. McCumber reported it as a substitute for the Sherwood bill, which had been referred to his committee. On March 9 the substitute was made the unfinished business of the Senate and was thereafter debated from time to time. Mr. McCumber said that the Sherwood bill, which had been passed by the House, would involve an annual increase of $\$ 75,000,000$ or more and that a bond issue would probably be required to provide the necessary funds. According to the estimates he had secured from the Pension Bureau, the substitute approved by the majority of the Senate committee would require an increase of pensions of $\$ 14,000,000$ for the first year, $\$ 33,000,000$ for the second year, and the average increase for a period of five years after its enactment would be $\$ 20,000,000 .^{3}$ He presented locu-

1 A few Republicans voted in the negative, including McCall, Gillett, and Gardner of Massachusetts, and Payne of New York. Among the northern Democrats against the bill were Fitzgerald, Littleton, and Redfield of New York, and Hughes of New Jersey.

2 The reluctance of members of the House of Representatives to vote against pension bills is easily understood. On June 30, 1912, there were 846,502 pensioners on the federal list in the continental United States, exclusive of the District of Columbia and Alaska. Taking the 435 seats in Congress to be filled at the fall elections in 1912, there were, on an average calculated for the whole country, 1946 pensioners per member. But the average number of pensioners to a congressional district in Kansas was 4,155; in Indiana, 4,032; in Ohio, 3,947; in Maine, 3,785; in Vermont, 3,435; in New Hampshire, 3,410; in Iowa, 2,746; in Missouri, 2,674; in Pennsylvania, 2,572; Washington, 3,584; Michigan, 3,019; Nebraska, 2,348; Illinois, 2,374; West Virginia, 2,238; Massachusetts, 2,258; Connecticut, 2,035; Maryland, 1,956; New York, 1,685; New Jersey, 1,628, etc. The averages are computed on the basis of the number of districts in each state at the election of 1912 . Some states also had representatives-at-large whose constituency was the whole population of the state.

${ }^{3}$ Cong. Record, 62d Cong., 2d Sess., Part 4, 3256-3257. 
mentary evidence that the Committee on Pensions of the G. A. R. had endorsed officially a bill based on a combination of age and service standards, and that individual members of the G. A. R. committee had endorsed the Senate substitute. ${ }^{1}$

Although a minority of the Senate Committee on Pensions reported in favor of the Sherwood bill, the substitute as presented by Mr. McCumber passed by an overwhelming majority. Upon disagreement with the House a conference committee was appointed. In the main the conference committee adopted the Senate bill, but the rates to be paid veterans of sixty-six, seventy, and seventy-five years, who had performed long periods of service, were somewhat increased. ${ }^{2}$ Both houses agreed to the conference report, and the bill became law by the signature of President Taft on May 11, 1912. ${ }^{3}$

This act granted pensions to persons who served ninety days or more in the Civil War and were sixty-two years of age or over. The monthly rate of the pension varied both according to age and length of service as shown in the following schedule:

Length of SeRvice.

\begin{tabular}{crrrrrrr}
\hline Age & 90 days & 6 months & 1 year & $11 / 2$ years & 2 years & $21 / 2$ years & 3 years \\
\hline $62 \ldots \ldots \ldots$ & $\$ 13.00$ & $\$ 13.50$ & $\$ 14.00$ & $\$ 14.50$ & $\$ 15.00$ & $\$ 15.50$ & $\$ 16.00$ \\
$66 \ldots \ldots \ldots$ & 15.00 & 15.50 & 16.00 & 16.50 & 17.00 & 18.00 & 19.00 \\
$70 \ldots \ldots \ldots$ & 18.00 & 19.00 & 20.00 & 21.50 & 23.00 & 24.00 & 25.00 \\
$75 \ldots \ldots \ldots$ & 21.00 & 22.50 & 24.00 & 27.00 & 30.00 & 30.00 & 30.00 \\
\hline
\end{tabular}

There was included in the act of 1912 a provision that pensions should be paid at the maximum rate of thirty dollars per month, without regard to age or length of service, to persons who served in the Civil War and were honorably discharged and who are now disabled from performing manual labor as the result of wounds received in battle or in the line of duty or as the result of disease or other causes incurred in the line of duty.

1 Cong. Record, 62d Cong., 2d Sess., Part 4, 3370.

2 Ibid., 3377, 6236.

${ }^{3} U$. S. Statutes at Large, xxxvii, 112. 
This provision was substantially a duplication of the existing general law.

The act also granted pensions at the rate of thirty dollars a month to all persons who had served sixty days or more in the War with Mexico and had been honorably discharged.

When the conference report on the act of 1912 was under consideration in the Senate and the bill was in its final form, Commissioner of Pensions Davenport estimated that it would increase the annual value of the pension roll $\$ 25,797,702$. The probable number of beneficiaries was estimated as 420,965 and the average annual increase per pensioner as $\$ 61.28 .^{1}$

Immediately after the approval of the new pension law, the Pension Bureau furnished over 600,000 application blanks to members of Congress, Grand Army posts, and individuals who made requests for them. In the forty-two business days of the fiscal year 1912 remaining after the approval of the act, the Pension Bureau received 406,048 applications. In August, 1912, Congress included an item of $\$ 300,000$ in the sundry civil appropriation bill to employ a force of temporary clerks to expedite the settlement of claims under the act of May 11. By June $30,1913,504,938$ applications had been received, and 429,369 pension certificates had been issued. Only 894 of these certificates were original allowances to persons never before on the pension roll under other laws.

The act of 1912 superseded the service-and-age act of February 6,1907 , and most of the pensioners under the latter act were soon transferred to the roll under the act of 1912 to secure the benefit of higher rates. The amount paid as pensions was increased from $\$ 152,986,000$ in the fiscal year 1912 to $\$ 174$,161,000 in 1913 and $\$ 172,409,000$ in 1914. In 1913 the expenditure for pensions was the largest in the history of the country, and it has not since been exceeded. There were 820,200 pensioners on June 30,1913 , as compared with the maximum number of 999,446 on June 30, 1902. The outlay in 1902 was $\$ 137,504,000$.

1 Cong. Record, 62d Cong., 2d Sess., Part 6, 5989. 
An act of March 4, 1913, required the Commissioner of Pensions to keep a record of the name, length of service, age, monthly rate of pension, and county and state of residence, of each pensioner under the act of 1912. At the end of the fiscal year 1914 , these records were to be tabulated by states and counties, and the Commissioner of Pensions was required to furnish certified copies of the same upon the payment of a fee. Further increases of rate under the act of 1912 were to be made without application, on account of the advancing age of the pensioners. The increase was to be made automatically for each pensioner from the date the above record showed him to have attained the age required for a higher rating. ${ }^{1}$

At the Los Angeles national encampment of the G. A. R., in September, 1912, the Committee on Pensions gave an account of its activities in securing the passage of the act of May 11, 1912, and expressed the opinion that it was the best pension law ever enacted. $^{2}$ During the next few years the G. A. R. organization interested itself especially in advocating more liberal provisions for widows, and especially in securing the admittance to the pension roll of those widows who had married after June 27, 1890, and whose husbands had not died from causes originating in the military service. ${ }^{3}$ The year of a presidential campaign again brought an important success in the passage of the act of September 8, 1916.

This law provided that, after its passage, every widow pensioner, who was the lawful wife of a soldier or sailor during his period of service in the Civil War, should have her pension increased to twenty dollars a month. It also fixed the pension rate for widows who were, or should thereafter be, pensioned on account of the War of 1812, the War with Mexico, and the Civil War, and who had reached, or should thereafter reach, the age of seventy years at twenty dollars a month. These provi-

1 U. S. Statutes at Large, xxxvii, 1019.

2 Journal of 46th National Encainpment, G. A. R., 1912, 196-202. 1914.

s See Journals of 4 th and 48 th National Encampments, G. A. R., 1913 and 
sions were applicable both to general law widows and to widows under the act of 1890 and supplementary legislation. ${ }^{1}$ On October 6,1917 , the pension rate for all Civil War widows was increased to twenty-five dollars a month. ${ }^{2}$

Prior to 1916 there were certain provisions of law under which general law widows, who had lost their pensions by reason of remarriage, might be restored to the pension roll upon again becoming widows, or upon being divorced without their own fault. The second section of the act of 1916 extended this privilege of restoration to the roll to Civil War widows whose soldier husbands died from causes not of service origin. In cases where remarried widows are restored to the rolls upon the death of, or upon divorce from, the later husband, the pension rates now established by law are allowed.

Section 3 of the act of 1916 extended by a period of fifteen years the limitation on the date of marriage of Civil War widows whose husbands did not die from causes of service origin. Prior to 1916 such widows could receive pensions of twelve dollars a month (after April 19, 1908) provided that their husbands served ninety days or more and also that the marriage occurred prior to June 27, 1890. The act of September 8, 1916, admitted to pensionable status widows of this class whose marriage took place prior to June 27, 1905.

A young woman who married an aged ex-soldier forty years after the Civil War ended may now be pensioned for life as his widow, provided that the soldier served at least ninety days and was honorably discharged. ${ }^{3}$ If such a young woman remarries, she forfeits her pension. But it will be restored upon the death

1 Pensions of 157,248 widows of the above classes were increased up to and including June 30,1917. Report of the Commissioner of Pensions for $1917,9$.

2 This increase was made by Section 314 of the recently enacted law providing insurance, compensation and other benefits for the protection of United States soldiers in the present European War. The increase to twenty-five dollars a month applies to all Civil War widows and widows of soldiers of the War with Spain and the Philippine Insurrection now on the pension roll, or hereafter to be placed on the pension roll.

3 See also provisions of the act of March 3, 1899, on page 141. 
of her second husband, or when she is divorced from her second husband upon her own application and without fault of her own. Section 3 of the act of 1916 contains, however, the proviso, "That where a pension has been granted to a soldier's or sailor's helpless or idiotic child or children, or child or children under the age of sixteen years, his widow shall not be entitled to pension under this section, unless the pension to such child or children has terminated, or unless such child or children be a member or members of her family and cared for by her, and upon allowance of pension to the widow, payment of pension to such child or children shall cease."

Thus, by the successive steps that have been described, there has been developed out of the act of June 27, 1890, a branch of our military pension system which cost down to the end of the fiscal year 1917 approximately $\$ 2,230,000,000$. This vast sum has been paid out to Civil War soldiers, their widows, and their dependent relatives in cases where no proof was furnished that any disability or injury was received, or disease contracted, in the military service. With the exception of some limitation on the granting of widows' pensions during the early part of the period, the amount has been distributed without discrimination between the poor and the prosperous. Until 1912 no special recognition was given to long and meritorious service during the war. The three months' man was pensioned on the same basis as the soldier who served through the whole war.

The former soldiers have constantly used their organized strength to secure greater and greater benefits at the expense of the taxpayers of the country. Recurring presidential campaigns have furnished favorable opportunity to make demands for pensions at a time when party leaders were particularly amenable to political pressure. The satisfaction of such demands has been the price of support at the polls. In more than one presidential campaign, the pension vote has played an extremely important part. Pensioners, and the relatives and friends of pensioners, have cast so many votes in the congressional districts of the North and West that it has taken unusual courage on the part 
of members of Congress to be recorded against pension bills, even when such measures were loose and extravagant in character.

The administration of the laws has also been hampered by political pressure and interference. Some administrations have been vigilant to protect the Treasury from imposition and fraud; others have been "liberal" to the point of facilitating the pensioning of persons whose claims were of doubtful merit or supported by false representations. Under the pension laws, imposition has often been easy and the fruits of dishonesty great. The provisions granting pensions for disabilities not of service origin have stimulated dependence among the veterans and tended to place the service of the citizen to the state upon too mercenary a basis.

As Professor Albert Bushnell Hart has said, the idea has found constant expression in Congress and in political discussion that the soldiers of the Civil War have a special claim on the national Treasury. ${ }^{1}$ Again and again members of Congress have taken the position that the payment of additional money for pensions was a preferred claim on any surplus that might be on hand. Changes in the internal revenue and tariff systems have been opposed on the ground that by decreasing the revenues from federal taxation they would reduce the amount available for the payment of pensions. Though it is perhaps too much to say that there has been a conscious alliance between those who desire a protective tariff and the great body of the ex-soldier voters, it is certain that influential leaders of the movement for increased pensions have persistently urged the old soldiers to oppose tariff reduction on the ground that any lessening of federal taxation would place obstacles in the way of larger pension expenditures. In recent years, however, Democrats have said in Congress that a party program of tariff reduction could now be carried out without prejudice to further pension grants by dependence upon

1 Albert Bushnell Hart, National Ideals Historically Traced, 281. 
the income tax to secure the needed funds for further disbursements among the old soldiers. ${ }^{1}$

While reviewing and deploring the abuses of the pension system in the past, it is fair to point out that the objections to service-pensions do not now have as great force as in 1890 and the decade immediately thereafter. The veterans of the Civil War are now all far advanced in years. Their service-pensions have become practically old age pensions. Yet the objection remains that the wealthy and prosperous receive the same provision as the poor. And, where service in the Civil War was short and without injury to the soldier, it does not seem clear that the exsoldier is more worthy of an old age pension than many other deserving citizens of equal age and inadequate means of support.

The members of the Grand Army of the Republic performed a great and imperishable service for their country, and they deserve the respect and gratitude of the millions who now enjoy the benefits won by their exertions and sacrifices. The unselfish and patriotic spirit in which the soldiers of the Union devoted themselves to an arduous task makes it all the more a matter for regret that in later years the persistent pursuit of pensions has often given a sordid tone to the activities of the Grand Army and other similar organizations. It is not conducive to high patriotism to form a judgment of the administration of government based on lavishness in the distribution of largess or the reverse. Yet the soldier organizations have frequently acted on this standard of judgment. It must be said, however, that there has always been a strong element in the G. A. R. in favor of moderation in the seeking of pensions-an element that has displayed a truly patriotic attitude in opposing unnecessary and extravagant claims on the Treasury.

The self-seeking spirit in the organizations of former soldiers was not a spontaneous growth. It was systematically cultivated and promoted by so-called "friends of the soldier"—claim agents

${ }^{1}$ Cong. Record, 62d Cong., 2d Sess., Part 1, 199. Remarks of Representative Littlepage and elsewhere in the debate on the act of May 11, 1912. 
and politicians who had fees or political advancement in view. The influence of George E. Lemon and his National Tribune did much to introduce and perpetuate this spirit in the Grand Army of the Republic. Many have been the politicians who have sought to ride into power on the strength of lavish pension promises held out to the old soldiers as an inducement to secure their votes. There is abundant evidence of the use of such methods in Indiana, Ohio, Kansas and other states. The political appeal to the soldier vote-backed by periodical increases of pensions-has been used by both the leading parties when opportunity afforded and continues to the present day. But the rapid inroads of death upon the Civil War pension list will soon greatly reduce the importance of this method of securing political support.

Critics of the Civil War pension system must admit that, considering its great cost and gross abuses, the people of the United States have borne the financial burdens of the system with only a moderate amount of complaint, if not with general contentment. For this condition a variety of explanations may be offered, all containing some degree of truth. Active or tacit support of the pension system has been based partly on a sentiment of gratitude, partly on self-interest, partly on indifference to burdens that were unfelt.

A feeling of genuine gratitude toward the men who fought to preserve the Union has predisposed the American people to lend a favorable ear to claims made in their behalf. Practically everyone is in favor of liberal provision for those who were wounded or injured, or contracted disease, in service, and for the widows, children, and dependent relatives of soldiers whose death was caused by service. Sentiment has not been so unanimous for pensions to ex-soldiers whose disabilities were not caused by military service, and to the widows and dependents of such soldiers. But even in cases of this class there has been a very general disposition to give the ex-soldiers the benefit of any doubts. The country has been rich and able to be generous. It has been felt that the veterans served the country when it was in need and that many of them may be worse off physically or otherwise because 
of their military service, without being able to furnish legal proof. In this state of the public feeling, the people have endured a great deal of obvious extravagance and fraud in order that meritorious claimants for places on the pension roll should not suffer by restrictions and safeguards framed to keep out the undeserving and corrupt. Hostile public sentiment has not been sufficient in strength to prevent the growth of the most lavish military pension system in the history of the world. At times its abuses have aroused widespread complaint, but, as a whole, the existence of the system has received at least a tacit approval.

Certain classes of people have had a direct personal interest in the maintenance of the pension system. From 1900 to 1905 there were nearly a million persons on the military pension list of the United States. In 1900 the population of the continental United States, exclusive of Alaska, was 75,994,575 and the number of federal pensioners in the same territory was 988,919 , or about one pensioner in 77 population. The pension list reached its maximum on June 30, 1902, with 999,446 names. All these people, with their families and relatives, have had a direct personal interest in the perpetuation and expansion of the pension system. Cooperating with them have been the powerful politicians and party leaders who have desired to gain the support of the pension interest at the polls in order to advance political aims and ambitions. An active and influential group of pension attorneys at the seat of government has been constantly at work to promote new pension legislation for the sake of the rich return in fees. Thousands of men and women have been employed at a cost of three or four millions of dollars a year in the Pension Bureau at Washington, in the various pension disbursing agencies, and in the boards of examining surgeons all over the country. Their positions and employment have depended upon the maintenance of the system. Manufacturing and other interests, which desired the maintenance of a tariff or revenue system producing at times great treasury surpluses, have looked upon the pension system as a most satisfactory means of returning these embarrassing surpluses to general circulation among the people. The 
constant inflow of pension money has seemed a blessing to whole communities and states which have in certain cases received annual amounts vastly larger than their proportionate contribution to the pension expenditure.

In 1900 there was one pensioner to 32 population in the District of Columbia, one pensioner to 35 in Maine, one to 36 in Kansas, one to 37 in Vermont, one to 37 in Indiana, and one to 40 in Ohio. The per capita distribution of pension money in the continental United States, exclusive of Alaska, was in 1900 $\$ 1.81$. On this basis Ohio would have received $\$ 7,525,000$ and Indiana $\$ 4,555,000$. They actually received $\$ 15,171,000$ and $\$ 10,339,000$ respectively. If these states contributed to federal taxation in proportion to their population, the operation of the pension system was obviously of great financial benefit to them. The expenditure of these millions has probably created throughout both of these commonwealths a favorable feeling toward the pension system.

Of course, the financial effect of the federal pension expenditures upon Southern states has been just the reverse. Maine, New Hampshire, and Vermont had in 1910 a total population of $1,529,000$. These states received in that year pension money amounting to $\$ 5,800,000$. South Carolina with almost the same population received in federal pensions in $1910 \$ 292,000$. If the single Southern state contributed equally with the New England trio to the federal taxes, the New Englanders enjoyed an advantage for that year of $\$ 5,500,000$ in the expenditure of the federal revenues for military pensions. Naturally extravagance and looseness in pension legislation are not popular in the South. But Southern members of Congress have usually been glad to support pension legislation for Union soldiers who were actually wounded or disabled in service. Their objections have been directed in the main at such service-pension legislation as has been developed out of the act of June 27, 1890. 


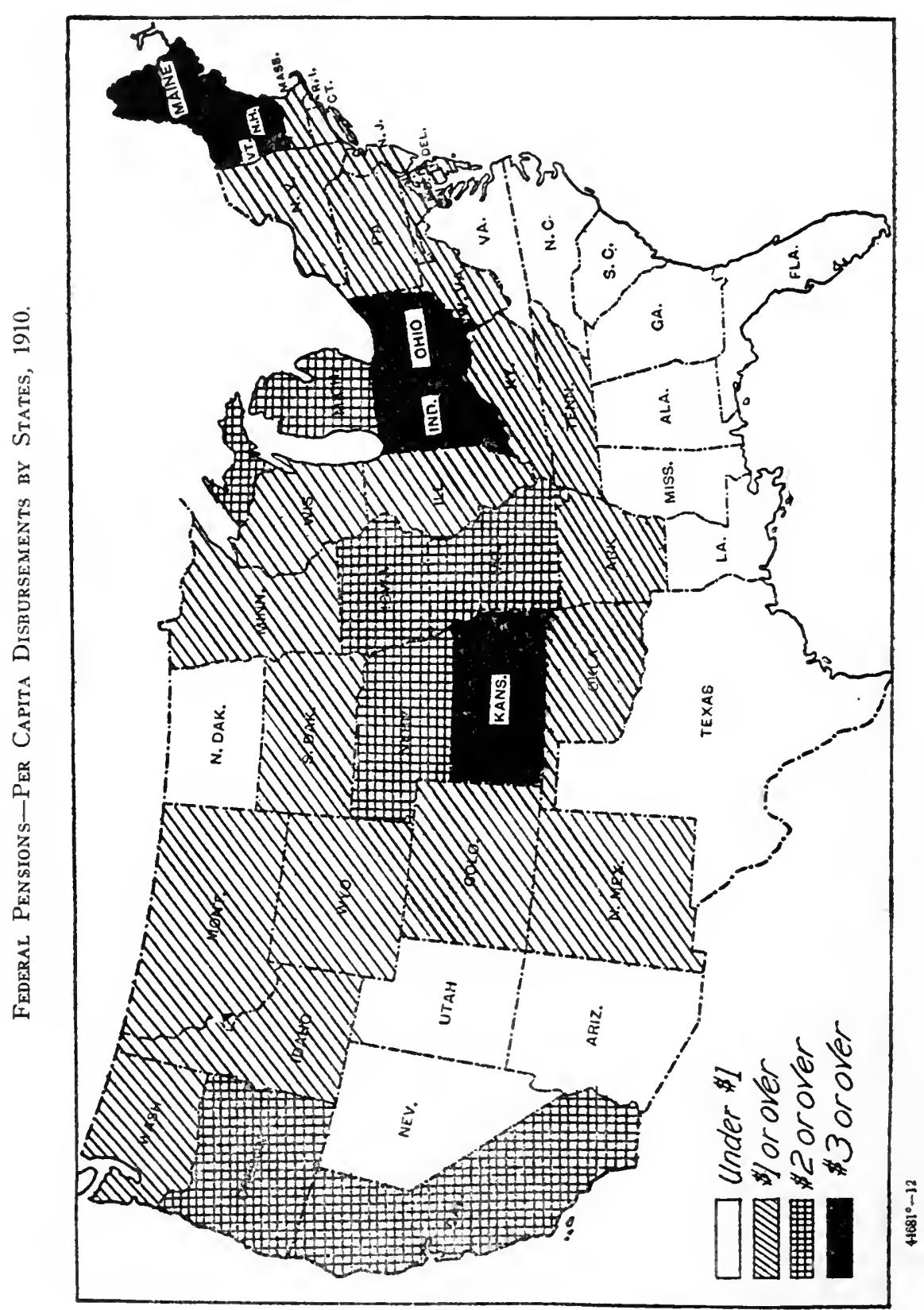


Receined per Capita in Federal Prnsions, 1910

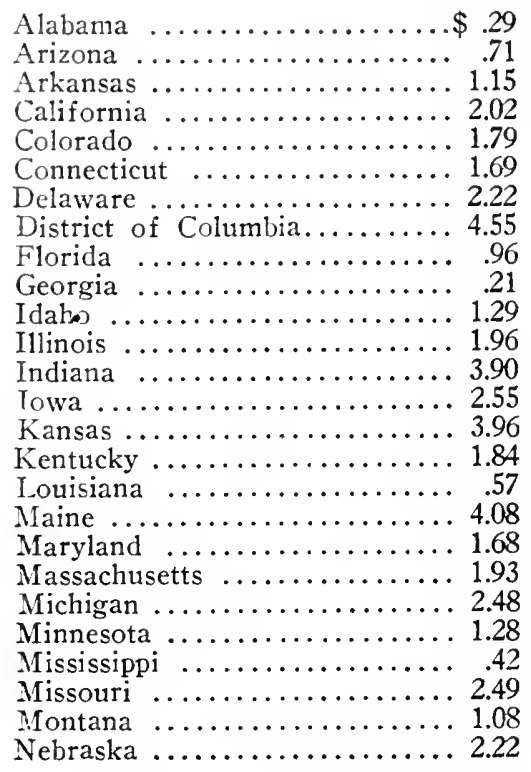

Nevada ................... \$ 89

New Hampshire ............. 3.10

New Jersey ................... 1.35

New Mexico ................ 1.07

New York ................. 1.49

North Carolina ............. .30

North Dakota .............. .70

Ohio ........................ 3.36

Oklahoma ................ 1.08

Oregon .................. 1.99

Pennsylvania ................... 1.97

Rhode Island ............. 1.59

South Carolina ................ 19

South Dakota ................ 1.35

Tennessee ................... 1.45

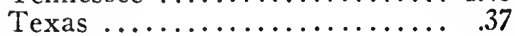

Utah ........................ .51

Vermont .................. 4.04

Virginia ...................... .74

Washington $\ldots \ldots \ldots \ldots \ldots \ldots, 1.63$

West Virginia ................ 1.72

Wisconsin ................... 1.83

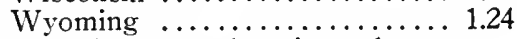

United States (continental, excluding Alaska) ............ 1.73

Doubtless a great number of citizens have not felt much sentiment either for or against the pension system. They have been indifferent to burdens that were unfelt. In such a situation the positive activities of those who were vitally interested have prevailed. If federal taxation for pensions had been direct and personal, if the average head of a family had been required to pay out eight or ten dollars annually as a tax for this specific purpose, it is very doubtful whether the pension system could have reached its present proportions. But when increased pension expenditures appeared in the guise of a distribution among the war veterans of unneeded and embarrassing millions of surplus raised by a system of taxation comparatively invisible and painless, the average citizen was not greatly concerned. If he thought that much of the money went to those who did not need it or to the unworthy, he probably reconciled himself to the situation by the reflection that the money might as well go in this direction as for some competing form of national extravagance. This use of the surplus was on the whole patriotic, and in any case it seemed useless to oppose the numerous pensioners and their influential friends. 
Including costs of administration, the United States has spent over $\$ 5,250,000,000$ for its military pension system since $1865 .^{1}$ Somewhat more than $\$ 200,000,000$ has been spent during that period of years on account of wars other than the Civil War. The costs of administration have been about $\$ 133,000,000$. Of the Civil War pension expenditure more than $\$ 2,230.000,000$ has been paid as pensions under laws which required no proof that disability or death was due to causes originating in the military service. This class of expenditures will eventually far exceed the expenditures under the general law system, which requires proof that disability or death originated in the service. In the last twenty-five years general law pension expenditures have been declining without much interruption and service-pension expenditures have been as constantly increasing.

\section{Statistical Tables}

The most costly single military pension law enacted by this or any other country was the act of June 27,1890 . As amended by the act of May 9.1900, and interpreted by Order No. 78, the expenditures under the act of 1890 up to the end of the fiscal year 1907 were as follows:

YeAr Ending June 30

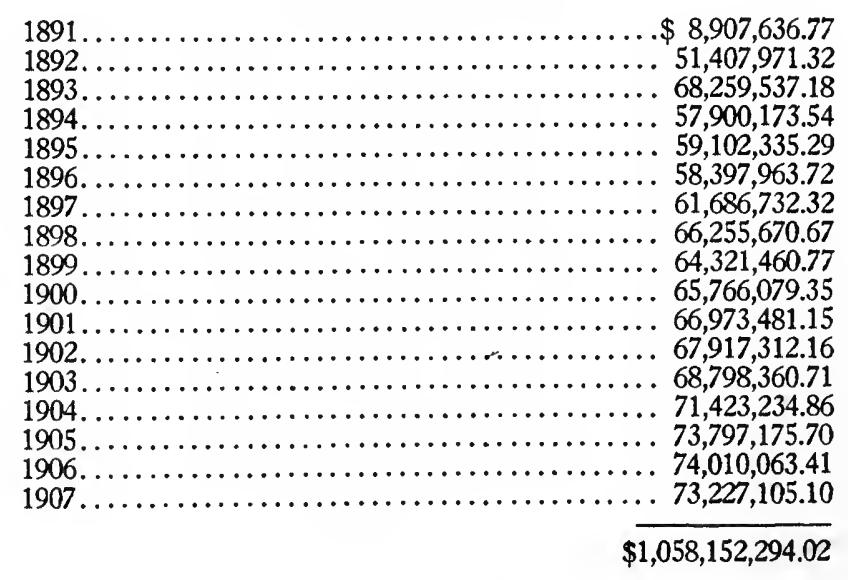

1 During the fiscal years 1866 to 1917 inclusive. Report of the Commissioner of Pensions for 1917, 29-30. 
Although the acts of February 6, 1907, and April 9, 1908, to a large extent superseded the act of June 27, 1890, important expenditures continued to be made under the act of 1890 for many years. By the fiscal year 1915 such expenditures had decreased to about a million dollars.

The decline of the general law pension system and the growth of the system under the act of 1890 is shown by the following table of the relative numbers of pensioners under the act of 1890 and the general law between 1891 and 1907 :

Number of Civil War Pensioners Under the Act of 1890 and Under the General Law From 1891 to 19071

\begin{tabular}{|c|c|c|c|c|c|c|c|}
\hline \multirow{2}{*}{\multicolumn{2}{|c|}{$\begin{array}{l}\text { Fiscal Year } \\
\text { Ending } \\
\text { June } 30\end{array}$}} & \multicolumn{3}{|c|}{ General Law } & \multicolumn{3}{|c|}{ Act of 1890} \\
\hline & & Invalids & Widows & Total & Invalids & Widows & Total \\
\hline 1891 & & 419,046 & 111,128 & 530,174 & 101,112 & 13,645 & 114,757 \\
\hline 1892 & $\ldots$ & 394,794 & 111,280 & 506,074 & 293,068 & 47,613 & 340,681 \\
\hline 1893 & $\ldots$ & 365,440 & 110,222 & 475,662 & 377,202 & 81,952 & 459,155 \\
\hline 1894 & .. & 362,274 & 105,485 & 467,759 & 375,084 & 94,260 & 469,344 \\
\hline 1895 & & 357,223 & 102,663 & 459,886 & 378,115 & 100,800 & 478,915 \\
\hline 1896 & $\ldots$ & 349,624 & 99,520 & 449,144 & 383,818 & 107,103 & 490,921 \\
\hline 1897 & & 341,087 & 96,993 & 438,080 & 392,440 & 116,359 & 508,799 \\
\hline 1898 & & 331,913 & 94,857 & 426,770 & 413,909 & 125,729 & 539,638 \\
\hline 1899 & & 321,555 & 92,901 & 414,456 & 420,912 & 130,266 & 551,178 \\
\hline 1900 & & 310,602 & 90,788 & 401,390 & 430,657 & 135,726 & 566,383 \\
\hline 1901 & & 297,675 & 88,811 & 386,486 & 438,114 & 145,111 & 583,225 \\
\hline 1902 & & 282,325 & 89,317 & 371,642 & 442,141 & 155,178 & 597,319 \\
\hline 1903 & $\ldots$ & 268,281 & 89,092 & 357,373 & 443,721 & 162,241 & 605,692 \\
\hline 1904 & & $* 240,785$ & $* 85,374$ & *326,159 & 450,007 & 168,589 & 618,596 \\
\hline 1905 & $\ldots$ & 219,384 & 84,482 & 303,866 & 465,224 & 176,125 & 641,349 \\
\hline 1906 & & 205,375 & 84,776 & 290,151 & 461,078 & 179,678 & 640,756 \\
\hline 1907 & & 178,816 & 82,395 & 261,211 & 349,283 & 184,863 & 534,146 \\
\hline
\end{tabular}

*Previous to this year the regular establishment was included with the Civil War pensioners under the general law. War with Spain pensioners under the general law are separately reported on page 145.

The further decrease of general law pensioners from 1907 to 1916 inclusive, and the effects of the acts of February 6, 1907, April 9, 1908, and May 11, 1912, in superseding the act of 1890 , are shown in the following table:

${ }^{1}$ Compiled from the annual reports of the Commissioner of Pensions. 


\section{FEDERAL MILITARY PENSIONS IN THE UNITED STATES}

Number of Civil War Pensioners on the Rolls Under the General Law, Act of 1890, Act of February 6, 1907, Act of April 9, 1908, and Act of May 11, 1912-From 1907 To $1917 .{ }^{1}$

\begin{tabular}{|c|c|c|c|c|c|c|c|c|c|}
\hline \multirow{2}{*}{$\begin{array}{c}\text { Fiscal } \\
\text { Y'ear } \\
\text { Ending } \\
\text { June 30 }\end{array}$} & \multicolumn{3}{|c|}{ General Law } & \multicolumn{3}{|c|}{ Act of 1890} & \multirow{2}{*}{$\begin{array}{c}\text { Act of } \\
1907 \\
\text { Survivors }\end{array}$} & \multirow{2}{*}{$\begin{array}{c}\text { Act of } \\
1908 \\
\text { Widows }\end{array}$} & \multirow{2}{*}{$\begin{array}{c}\text { Act of } \\
1912 \\
\text { Survivors }\end{array}$} \\
\hline & Invalids & $\begin{array}{l}\text { Widows } \\
\text { and De- } \\
\text { pendents }\end{array}$ & Total & Invalids & $\begin{array}{l}\text { Minors, } \\
\text { etc. }\end{array}$ & Total & & & \\
\hline 907 & 178,816 & 82,395 & 261,211 & $349,28 ?$ & *184,863 & 534,146 & 116,239 & & \\
\hline & 142,044 & 81,395 & & 140,600 & 4,249 & 144,849 & 338,341 & 188.445 & \\
\hline 1909 & 131,0 & 78,13 & 209,2 & 104,5 & 4,33 & 108,914 & 358,315 & 211 , & \\
\hline 1910 & 121,5 & 74,625 & 196,206 & 78,601 & 4,344 & 82,945 & 362,433 & 221,268 & \\
\hline & $113, \mathrm{C}$ & 70,910 & 183 & 5 & 4,3 & & 356,830 & 228,604 & \\
\hline 1912 & 103,237 & 66,947 & 170,184 & 47,201 & 4,479 & 51,680 & 333,579 & 232,947 & 13,246 \\
\hline 1013 & 61,800 & 62 & 124,3 & 5,274 & 4,2 & & 16,241 & 232,864 & 379,064 \\
\hline 1914 & 50,347 & 58,868 & 109,215 & 2,225 & 4,091 & 6,3 & 7,158 & 235,524 & 369,624 \\
\hline & & 56,020 & 101,3 & 1,081 & 3,854 & & & 235,087 & 347,081 \\
\hline 1916 & 39,593 & 52,217 & 91,8 & 681 & 3,725 & 4,406 & 1,727 & 235,536 & 320,276 \\
\hline 1917 & 36,076 & 49,039 & 85,115 & 537 & 3,125 & 3,662 & 1,345 & $\div 236,725$ & 291,268 \\
\hline
\end{tabular}

*Includes widows, later listed separately under the act of 1908.

† Includes additions to the widows' rolls under the act of September 8, 1916.

The following table exhibits by years the disbursements for pensions and maintenance of pension system, 1866 to $1917: 1$

1 Compiled from the annual reports of the Comissioner of Pensions. 


\begin{tabular}{|c|c|c|c|c|c|}
\hline \multicolumn{2}{|c|}{ Fiscal Year } & \multirow{2}{*}{$\begin{array}{c}\begin{array}{c}\text { Paid } \\
\text { as Pensions }\end{array} \\
\$ 15,450,549.88\end{array}$} & \multirow{2}{*}{$\begin{array}{l}\begin{array}{c}\text { Cost, Mainte- } \\
\text { nance, and } \\
\text { Expenses }\end{array} \\
\$ 407,165.00\end{array}$} & Total & \multirow{2}{*}{$\begin{array}{l}\begin{array}{c}\text { Number } \\
\text { of Pen- } \\
\text { sioners }\end{array} \\
126,722\end{array}$} \\
\hline 1866 & & & & $\$ 15,037,114 . \infty$ & \\
\hline 1867 & $\ldots \ldots \ldots \ldots$ & $20,784,789.69$ & $490,977.35$ & $21,275,767.04$ & 155,474 \\
\hline 1868 & $\ldots \ldots$ & $23,101,509.36$ & $553,020.34$ & $23,654,529.70$ & 169,643 \\
\hline 1869 & & $13,247.27$ & $564,526.81$ & $29,1,77,774.08$ & 187,963 \\
\hline 1870 & $\ldots$ & $51,488.78$ & $600,997.86$ & $29,952,486.64$ & 198,686 \\
\hline 1871 & . & $28,518.792 .62$ & $863,079.00$ & $29,381,871.62$ & 207,495 \\
\hline 1872 & & $29,752,746.81$ & $951,253.00$ & $30,703,999.81$ & 232,229 \\
\hline 1873 & & $26,982,063.89$ & $1,003,200.64$ & $27,985,264.53$ & 238,411 \\
\hline 1874 & & $30,206,778.99$ & $966,794.13$ & $31,173,573.12$ & 236,241 \\
\hline 1875 & & $29,270,404.76$ & $982,695.35$ & $30,253,100.11$ & 234,821 \\
\hline 1876 & & $27,936,209.53$ & $1,015,078.81$ & $28,951,288.34$ & 232,137 \\
\hline 1877 & & $28,182,821.72$ & $1,034,459.33$ & $29,217,281.05$ & 232,104 \\
\hline 1878 & & $26,786,009.44$ & $1,032,500.09$ & $27,818,509.53$ & 223,998 \\
\hline 1879 & & $33,664,428.92$ & $837,734.14$ & 34,502 , & 242,755 \\
\hline 1880 & & $39,229.08$ & 935.027 .28 & .36 & 250.802 \\
\hline 1881 & & 5.35 & $1,072,059.64$ & 64.99 & 268,830 \\
\hline 1882 & & 2.05 & $1,466,23$ & $55,779,408.06$ & 285,697 \\
\hline 1883 & & 60,4 & $2,591,648.29$ & $6 \hat{3}, 019,222.10$ & 303,658 \\
\hline 1884 & & 2.387 .47 & $2,835,181.00$ & $60,747,568.47$ & 322,756 \\
\hline 1885 & & $65,171,937.12$ & $3,392,576.34$ & $68,564,513.46$ & 345,125 \\
\hline 1886 & & $64,091,142.90$ & $3,245,016.61$ & $67,336,159.51$ & 365,783 \\
\hline 1887 & & $73,752,997.08$ & $3,753,400.91$ & $77,506,397.99$ & 406,007 \\
\hline 1888 & & $78,950,501.67$ & $3,515,057.27$ & $82,465,558.94$ & 452,557 \\
\hline 1889 & & $88,842,720.58$ & $3,466,968.40$ & $92,309,688.98$ & 489,725 \\
\hline 1890 & & $106,093,850.3 \mathrm{~S}$ & $3,526,382.13$ & $109,620,232.52$ & 537,944 \\
\hline 1891 & & $117,312,690.50$ & $4,700,636.44$ & $122,013,326.94$ & 676,160 \\
\hline 1892 & & $4,147.11$ & $4,898,665.80$ & $144,292,812.91$ & 876,068 \\
\hline 1893 & & 37.94 & 4,8 & $161,774,372.36$ & 966,012 \\
\hline 1894 & & 13 & 3,9 & 02.48 & 969,544 \\
\hline 55 & & 4.30 & 020.21 & 144,150 & 970,524 \\
\hline 1896 & & 704.46 & $3,991,375.61$ & $142,212,080.07$ & 970,678 \\
\hline 1897 & &, 717.35 & $3,987,783.07$ & $143,937,500.42$ & 976,014 \\
\hline 1898 & & $1,879.80$ & $4,114,091.46$ & $148,765,971.26$ & 993,714 \\
\hline 1899 & & $5,052.95$ & $4,147,517.73$ & $142,502,570.68$ & 991,519 \\
\hline 1900 & & $462,130.65$ & $3,841,706.74$ & $142,303,887.39$ & 993,529 \\
\hline 1901 & & 531,483 . & $3,868,795.44$ & $142,400,279.28$ & 997,735 \\
\hline 1902 & & $137,504,267.99$ & $3,831,378.96$ & $141,335,646.95$ & 999,446 \\
\hline 1903 & & $137,759,653.71$ & $3,993,216.79$ & $141,752,870.50$ & 996,545 \\
\hline 1904 & & $141,093,571.49$ & $3,849,366.25$ & $144,942,937.74$ & 994,762 \\
\hline 1905 & & 42,861 . & $3,721,832.8$ & $144,864,694.15$ & 998,441 \\
\hline 1 & & 13 & $3,523,269.51$ & $142,523,557.76$ & 985,971 \\
\hline 97 & & 13 & 3,309 & $141,464,522.90$ & 967,371 \\
\hline 1908 & & & 2,8 & & 951,687 \\
\hline 1909 & & 703.77 & $2,852,583.73$ & $164,826,287.50$ & 946,194 \\
\hline 1910 & & $974,056.08$ & $2,657,673.86$ & $162,631,729.94$ & 921,083 \\
\hline 1911 & & $325,160.35$ & $2,517,127.06$ & $159,842,287.41$ & 892,098 \\
\hline & & $986,433.72$ & $2.448,857.31$ & $155,435,291.03$ & 850.294 \\
\hline & & $174,171,660.80$ & $2,543,246.59$ & $176,714,907.39$ & 820,200 \\
\hline 1 & & $172,417,546.26$ & $2,066,507.15$ & $174,484,053.41$ & 785,239 \\
\hline & & $18,266.14$ & $1,779,860.30$ & $167.298,126.14$ & 748,147 \\
\hline & & $55,089.92$ & $1,656,722.33$ & 160.811 .812 .25 & 709.572 \\
\hline 1917 & & $160,895,053.94$ & $1,562,854.96$ & $162,457,908.90$ & 673,111 \\
\hline & & & $\$ 132,937,910.38$ & .09 & \\
\hline
\end{tabular}

${ }^{1}$ From the Report of the Commissioner of Pensions for 1917, pages 29-30. 
The following tabie shows the total amount paid to the pensioners of the various wars in which the United States has been engaged, 1790 to 1917 , inclusive. ${ }^{1}$ It exhibits in a striking manner the vast importance of Civil War pension expenditures as compared with the disbursements on account of the lesser wars:

War of the Revolution ............ \$70,000,000.00

War of $1812 \ldots \ldots \ldots \ldots \ldots \ldots \ldots .46,010,445.70$

Indian Wars ................. 14,204,296.51

War with Mexico .............. 51,264,284.61

Civil War .................... 4,917,245,599.49

War with Spain and F'hilippine Insurrection $\quad 57,528,347.49$

Regular Establishment ........... 42,764,359.73

Unclassified $\ldots \ldots \ldots \ldots \ldots \ldots \ldots \ldots \quad 16,508,447.41$

Total $\ldots \ldots \ldots \ldots \ldots \ldots \ldots \ldots 5,215,525,780.94$

1 From Report of the Commissioner of Pensions for 1917, p. 29. 


\section{CHAPTER IV \\ Special Pension Legislation}

The foregoing chapters have shown the great liberality of the provisions made by general pension legislation for the soldiers of the Civil War and their dependent relatives. These liberal provisions have been supplemented by a large amount of private pension legislation. Before the Civil War few private pension acts were passed. Prior to the end of the 47 th Congress in 1883, the greatest number of such acts passed by any one Congress was 275 by the 40th Congress (1867-1869). Beginning with the 48th Congress there was a marked increase in such legislation, and a maximum was reached when the 61st Congress (19091911) granted 9,649 pensions by special act. That was at the average rate of 20 for each one of the 483 members of the two Houses. The high record of 9,649 special grants made by the 61 st Congress may be compared with a total of 8,182 pensions granted by special act by all the Congresses in the period of forty years from March 4, 1861, to March 4, 1901.

Many of the private acts have been passed to allow claims which the pension committees of the two Houses considered to be meritorious, but which did not come technically within the provisions of the general law. Such acts, however, have often placed on the pension roll claimants whose applications had already been investigated by the Pension Bureau and had been found to be absolutely without merit. In recent years the great majority of pensions granted by special act are in the nature of increases to rates in excess of the amounts provided for in the general laws. ${ }^{1}$ In such cases the claim is usually made that the circumstances of the particular applicant justify a rate higher

1 The $63 \mathrm{~d}$ Congress granted 4,167 pensions by special act in the fiscal year 1914-15. Of these, 918 were granted to persons not in receipt of a pension and 3,249 to persons then receiving sinaller pensions. The annual value of these special act pensions was $\$ 1,257,006$, and the annual increase due to the same was $\$ 552,507$. Report of the Commissioner of Pensions for 1915,31 . 
than that normally paid. But it is fairly obvious that such increases are due more to the favor of members of Congress than to any just and careful comparison of the merits and necessities of the applicants with those of other pensioners receiving the same allowance. The passage of a certain number of private pension acts has become practically a perquisite of Senators and Representatives to be used according to the dictates of influence, acquaintance, or political expediency. The principal legislative activity of some members is in securing the passage of private pension bills. ${ }^{1}$

Applications for pensions by special act are referred to the pension committees of the two Houses. In some Congresses rules have been enforced by the committees under which claims have received reasonable consideration and investigation. At other times the practice has been very lax. In 1888, when the number of such bills before Congress was much smaller than in recent years, Senator McPherson of New Jersey said of the methods of the Senate Pension Committee: "The bills are introduced in great numbers (I myself have introduced 200), and they are then referred to the Pension Committee. This committee divides the bills equally among its members, and each one is supposed to examine a certain number of bills. Instead of giving each bill a careful investigation, I know, as a matter of fact, that in many cases the Senators have merely turned over the batch to their secretaries, and have instructed these clerks to look into the matter." 2

When many thousands of applications for special pensions are before Congress, thorough investigation by a congressional committee or its employes is obviously out of the question. When

1 Akin to special pension laws are a great number of acts to correct the military record of ex-soldiers who have applied for pensions. The general pension laws make honorable discharge a requisite for a pension. Applicants recorded as deserters in the army records are barred. When a claim is made that the record is wrong or that there were extenuating circumstances, it is a common practice to pass private acts removing the charge of desertion from the record.

2 New York Times, November 6, 1888, p. 2, col. 5. 
the Pension Bureau has been called upon, it has usually been able to furnish certain of the essential facts. ${ }^{1}$ It has been the custom of both Houses of Congress to set aside portions of certain days for the consideration of pension bills. In the great majority of cases the private pension bills receive no consideration other than that given by the committee. On "pension day" there is commonly no quorum present. In the presence of a few members, it has been a general practice to take up the pension bills reported by the committee and put them through the form of passage in a perfunctory manner and with remarkable speed. In some Congresses they have been passed at the rate of two or three a minute. ${ }^{2}$ Very few members take the trouble to vote on such occasions or give any attention to the procedure, which is by general consent. Occasionally some disguested Southern member, or some member who has a grievance, stops the process temporarily by insisting on the presence of a quorum. Instead of passing a separate law granting each pension, Congress has in recent years followed the practice of including many grants of special pensions as items in a sort of omnibus bill. Under this practice, if the President were disposed to veto some objectionable grants he could not do so without at the same time causing the failure of all the other pension provisions in the bill.

However, Presidents have been sparing in the use of the veto against private pension bills. President Grant vetoed five measures of this sort. The increasing number of special pension acts and the carelessness with which they were passed caused President Cleveland to interpose the executive power against a growing abuse. Instead of signing such private bills perfunctorily,

${ }^{1}$ In the 56th and 57th Congresses, there was a commendable disposition to check the flood of applications for pensions by special act. Detailed rules limiting and governing applications were adopted by the pension committees of the two Houses. These rules may be found in the pamphlet report of the Commissioner of Pensions for 1903, page 97. One object of these rules was to secure a prior consideration of every application by the Pension Bureau. The rules did not prevent a great increase in such applications.

2 For instance, on July 25, 1889, the Senate passed 130 private pension bilis in 50 minutes, an average of one in 23 seconds. See New York Times, August 7,1888 , p. 4 , col. 3 . 
he had them investigated and vetoed grants that he thought without merit. In his first term the number of special pension acts that became law was 1,871 . Many of these were permitted to become law without the President's signature. During the same four years $\mathrm{Mr}$. Cleveland vetoed 228 such measures. In 175 cases the bills were vetoed on the ground that the injuries alleged were not received "in military service and in the line of duty." In another class of cases, because of a fault in the bill or because of the operation of some general law, the President thought that the special acts would have been of no benefit to the claimants. Other vetoes were on the ground that proposed increases were not warranted, that dependency alleged was not established, that the applicants were deserters, and that the applicants were unworthy for miscellaneous reasons. ${ }^{1}$

President Cleveland was the object of bitter political attacks because of his vetoes of the Dependent Pension Bill, as described in a previous chapter, and of the large number of private pension bills. The sarcastic language of some of the veto messages was seized upon to stir up feeling against the President among the ex-soldiers. ${ }^{2}$ In Congress the vetoes were sharply criticized both on the ground that the President had unjustly concluded that the cases were not meritorious, and on the ground that it was improper to use the veto power against acts of Congress in questions involving matters of fact. The President depended for his information on the Pension Office, and a Senate committee, reporting in 1888, found that with rare exceptions the vetoes were

\footnotetext{
1 For an analysis of President Cleveland's pension vetoes, see E. C. Mason, The Veto Power, 87-93.

$2 \mathrm{Mr}$. Cleveland's political opponents made the pension vetoes a prominent issue in the campaign of 1888 . They were denounced in both the Republican platform and in the campaign textbook. The National Tribune, the most widely circulated organ of the pensioners and claimants, made repeated attacks on the President. For instance, on September 27,1888, it said: "An unprecedented number of these [private pension acts] have been presented to $\mathrm{Mr}$. Cleveland for his signature, and he has found in them a boundless field for ridicule, cheap wit, sarcasm, satire, and vituperation of the unfortunates who were so indiscreet as to go into the army and lose their health or lives. -. The President has been amusing himself for years zeriting vetoes. The veterans now have a chance to use their hands at vetoing. Let them improve the opportunity."
} 
well founded. ${ }^{1}$ The contention that the use of the veto was improper in questions of expediency or fact did not make great headway in the face of the gradual broadening of the power since its incorporation in the Constitution.

The determined stand of Mr. Cleveland against the abuse of special pension legislation had the effect of bringing to the attention of the country the recklessness of Congress in such matters and of securing for a time at least the more careful investigation of private pension claims in the congressional committees. Though the Republican 51st Congress-the first of President Harrison's administration-passed 1,388 private pension acts, the party was committed to liberality in this direction by reason of its criticism of Mr. Cleveland's record. In the second half of the Harrison administration the House of Representatives was overwhelmingly Democratic, and only 217 special pension acts were passed. In the four years of Cleveland's second administration 497 private pension bills became law. Mr. Cleveland's successors in the Presidency have not emulated his record of opposition to private pension bills. In the McKinley and Roosevelt administrations the number of such measures increased very largely, and in Mr. Taft's administration 15,999 pensions were granted by special act.

Congress is obviously not a suitable place for the investigation and just settlement of private pension claims. The pressure of general business is too great. There is little time for the detailed discussion of such matters on the floor of either House, and the recommendation of the pension committees must usually be followed without question if business is to be done. These committees can give no proper consideration to the thousands of claims presented. The passage of a certain number of pension claims upon plausible representations becomes practically a form of congressional patronage. Some members are assiduous in seeking pensions for constituents to the exclusion of activities of a more public nature. It would be an improvement upon present methods

1 Senate Report No. 1667, 50th Cong., 1st Sess. 
if Congress should pass special pension bills only upon the recommendation of the Pension Bureau. The general pension laws are liberal, and the number of meritorious claims not within their scope must be very limited. The officers of the Pension Bureau have better facilities to learn the facts, and form a just opinion in exceptional cases, than Congress, and the history of the Bureau will not convict it of bias against claimants. Under the present system, there is unfair discrimination against the pensioners under the public laws by reason of the great number of increases secured by private bills for those who are able to gain the favor and aid of Senators and Representatives.

The following is a statement of the number of pensions and increases of pensions granted by special acts during each Congress since March 4, $1861:^{1}$

$\begin{array}{lr}\text { Thirty-seventh }(1861-1863) \ldots & 12 \\ \text { Thirty-eighth }(1863-1865) \ldots \ldots & 27 \\ \text { Thirty-ninth }(1865-1867) \ldots \ldots & 138 \\ \text { Fortieth }(1867-1869) \ldots \ldots \ldots & 275 \\ \text { Forty-first }(1869-1871) \ldots \ldots \ldots & 85 \\ \text { Forty-second }(1871-1873) \ldots \ldots & 167 \\ \text { Forty-third }(1873-1875) \ldots \ldots & 182 \\ \text { Forty-fourth }(1875-1877) \ldots \ldots & 98 \\ \text { Forty-fifth }(1877-1879) \ldots \ldots & 230 \\ \text { Forty-sixth }(1879-1881) \ldots \ldots & 96 \\ \text { Forty-seventh }(1881-1883) \ldots \ldots & 216 \\ \text { Forty-eighth }(1883-1885) \ldots \ldots & 598 \\ \text { Forty-ninth }(1885-1887) \ldots \ldots & 856 \\ \text { Fiftieth }(1887-1889) \ldots \ldots \ldots & 1,015 \\ \text { Fifty-first }(1889-1891) \ldots \ldots \ldots & 1,388\end{array}$

Fifty-second (1891-1893)..... 217

Fifty-third $(1893-1895) \ldots \ldots . .6 .219$

Fifty-fourth $(1895-1897) \ldots \ldots .6378$

Fifty-fifth $(1897-1899) \ldots \ldots . .694$

Fifty-sixth $(1899-1901) \ldots \ldots .1,391$

Fifty-seventh $(1901-1903) \ldots \ldots 2,171$

Fifty-eighth $(1903-1905) \ldots \ldots .3,355$

Fifty-ninth $(1905-1907) \ldots \ldots 6,030$

Sixtieth $(1907-1909) \ldots \ldots \ldots \ldots, 6,600$

Sixty-first $(1909-1911) \ldots \ldots \ldots .69,649$

Sixty-second $(1911-1913) \ldots \ldots, 6,350$

Sixty-third $(1913-1915) \ldots \ldots .6,5,061$

Sixty-fourth $(1915-1917) \ldots \ldots .5,885$

Total.............. $\overline{53,283}$

There were in 191721,474 persons on the pension roll whose pensions or increases had been granted by special act of Congress. The annual value of such pensions was $\$ 6,722,900$. Only a part of this annual expenditure can be attributed to special legislation, for the reason that most of the beneficiaries had been previously pensioned under the general pension laws at lower rates.

1 Report of the Commissioner of Pensions for 1917, 42. 
APPENDIX 
The War Insurance Law of October 6, 1917

The entry of the United States into the European War has furnished an opportune occasion for the adoption of a new policy for the future in the matter of national provisions for wounded and disabled soldiers and sailors and for the dependent relatives of those who lose their lives. In the absence of new legislation by Congress, the general law pension system already described would have applied to the military forces of the United States engaged in the present war. But, under the leadership and direction of Secretary of the Treasury McAdoo, a new plan for the protection of the fighting forces of the nation was prepared and submitted to Congress. In the drafting of this plan the Secretary of the Treasury availed himself of the expert assistance of Judge Julian W. Mack and of many lawyers, economists, insurance experts, persons skilled in problems of dependency, and other progressive leaders of thought. Congress, after revision and amendment, accepted by unanimous vote in both Houses the general plan proposed, and the new War Insurance Law (or Soldiers' and Sailors' Insurance Law) was approved by President Wilson on October 6, 1917. ${ }^{1}$

The new law is a radical departure from the existing pension system. It applies to service in the military and naval forces of the United States after the date of its approval. Existing pension laws are not disturbed in their application to previous wars. Their administration continues under the Commissioner of Pensions in the Department of the Interior. The new War Insurance Law is to be administered by the Bureau of War Risk Insurance in the Treasury Department. As now constituted this burean contains a Division of Marine and Seamen's Insurance and a Division of Military and Naval Insurance. The officer placed at the head of the bureau is called director. and at the head of each

${ }^{1}$ For a discussion of the War Insurance Law and an account of the circumstances under which it was prepared, see an article entitled "Soldiers" Insurance versus Pensions" by Professor Samuel McCune Lindsay of Columbia University in the Review of Reviews for October, 1917. Professor W. F. Gephart has prepared, under the auspices of the Carnegie Endowment for International Peace, a special monograph on the War Insurance Law of 1917. 
of the divisions is a commissioner. In the conduct of the bureau, the director is subject to the general direction of the Secretary of the Treasury. The Division of Marine and Seamen's Insurance administers the provisions of the act of September 2, 1914, for the insurance of ships and seamen in the merchant marine against war risks. The new Division of Military and Naval Insurance is charged with carrying out the various provisions of the act of October 6, 1917, for the benefit and protection of soldiers and sailors employed in the military or naval forces of the United States and their dependent relatives.

The leading features of the War Insurance Law are, in brief, as follows:

1. It provides for the support during the war of the families and dependents of enlisted men (but not of officers). This support is to be obtained by compulsory allotments of pay from the men to their families or dependent relatives, supplemented by monthly family allowances made by the United States government. While the allotment of pay is compulsory as to a wife or a child, it is voluntary as to other persons. The compulsory allotment for a wife and children is an amount equal to the family allowance made by the government but not more than cne-half pay or less than $\$ 15$ per month. An enlisted man may allot any proportion or amount of his pay in addition to the compulsory allotment for such purposes and persons as he may direct, subject to regulations. The government will make family allowances to rertain dependent relatives other than wife or children, provided the enlisted man makes a voluntary allotment in a required amount to such relative or relatives. In case one-half of an enlisted man's monthly pay is not allotted, the Secretary of War and the Secretary of the Navy may require him to deposit onehalf of his pay, or so much of one-half of his pay as is not allotted, in a Military and Naval Pay Deposit Fund. The money thus deposited is to accumulate at four per cent interest for the benefit of the men during the period of their service. Compulsory allotment may be waived on written consent of a wife, supported by evidence of her ability to support herself and children. Exemption from compulsory allotment may also be granted for good cause shown, subject to regulations.

2. The new law also provides compensation for disability or death due to injury or disease incurred in military service. This part of the law applies both to officers and enlisted men and their dependent relatives. It gives protection similar in many respects 
to that afforded by the old general law pension system to the soldiers of the Civil War. However, the compensation does not vary with rank, officers and enlisted men being protected by the same schedule of allowances. As a whole, the compensation allowances are on a more generous scale than the invalid-pensions under the general law system. It is especially to be noted that the compensation of a disabled man is fixed in proportion both to the degree of impairment of his earning capacity and to the size of the family dependent upon him. The compensation for widows and children is also proportioned to the size of families. Ratings of reductions in earning capacity from injuries of a permanent nature are to be based, "as far as practicable, upon the average impairments of earning capacity resulting from such injuries in civil occupations and not upon the impairment in earning capacity in each individual case, so that there shall be no reduction in the rate of compensation for individual success in overcoming the handicap of a permanent injury." In addition to compensation, injured persons are entitled to reasonable governmental medical, surgical, and hospital services and to useful and reasonably necessary supplies such as artificial limbs, trusses, and similar appliances. Persons in receipt of compensation for disability are required to submit to reasonable medical examinations, or medical or surgical treatment, at the discretion of the bureau. The United States may also require certain classes of injured persons to follow courses of rehabilitation, reeducation, and vocational training. The penalty of wilful failure to follow such courses is a suspension of the compensation for disability. Compensation under this law will not be paid to persons in receipt of service or retirement pay. The compensation is not assignable and is exempt from attachment and execution and from all taxation.

3 . In addition to compensation as above described for disability or death caused by war injuries, the War Insurance Law gives officers and enlisted men the right to secure from the government further protection in the form of insurance against death or total permanent disability in any multiple of $\$ 500$, and not less than $\$ 1,000$ or more than $\$ 10,000$. The exercise of this right is entirely optional. A man fit for military service is physically a first class risk. But when he enters such service, he can secure insur ance from private companies only at very high or prohibitive rates. The United States proposes to insure his insurability both for the present and after the war. This protection is to be in the form of term insurance renewable from year to year and con- 
vertible after the war, without medical examination, into various standard forms of insurance. The premium rates are to be the net rates based upon the American Experience Table of Mortality with interest calculated at three and one-half per cent per annum. The United States will bear the expenses of administration and the excess mortality and disability cost resulting from the hazards of war. For all persons in active military service on or after April 6, 1917, the plan includes a provision of automatic insurance covering the period until February 12, 1918, inclusive. Persons in active service at the time of the publication of the terms and conditions of the insurance may apply at any time within 120 days thereafter, while in service. This period expires February $12,1918 .{ }^{1}$ Other persons must apply for insurance within 120 days after enlistment and before discharge or resignation, from the service. No medical examination is required. Premiums may be deducted from the pay or deposit of the insured, unless the insured makes payment otherwise. The insurance is payable to the beneficiary or beneficiaries in 240 equal monthly instalments, but regulations providing certain alternative benefits may be made by the bureau. When the insured is the beneficiary in the case of total permanent disability, the monthly instalments will be continued throughout the duration of the disability. This insurance feature of the new law is novel and far reaching. While in course of preparation it was the subject of unfavorable criticism on the part of persons connected with existing insurance companies who do not favor the inauguration of state insurance. On the other hand, the insurance plan received the unqualified indorsement of the President, the Secretary of the Treasury, and of experts in social legislation. It is obvious that in case the present war is long protracted this new departure in public policy may have consequences of immense importance in many directions.

1 A joint resolution of Congress was approved hy President Wilson, February 12,1918 , for the purpose of extending the time during which persons in the military or naval service might apply for insurance to, and including, April 12, 1918. Official Bulletin, Februaty 13, 1918, p. 1. 


\section{Brief Outline of the Provisions and Schedules of the Act of October 6, 1917}

The government has had prepared for the information of men in the soldiers' training camps in the United States a pamphlet containing a simple statement of the most essential details of the War Insurance Law. This information is so conveniently arranged, with references to the appropriate sections of the law, that the greater portion of the pamphlet is here reprinted.

Definitions for the Purposes of the Act (Sec. 22)

"Military or naval forces" means the Army, the Navy, the Marine Corps, the Coast Guard, the Naval Reserves, the National Naval Volunteers, and any other branch of the United States service while serving pursuant to law with the Army or the Navy.

"Commissioned officer" includes a warrant officer, but includes only an officer in active service.

"Man" or "enlisted man" means person, male or female, in active service in the military or naval forces of the United States, and includes noncommissioned and petty officers and members of training camps.

"Injury" includes disease.

"Pay" means the pay for service in the United States according to grade and length of service, excluding all allowances.

"Child" is limited to an unmarried person either under 18 years of age, or incompetent, and includes, under certain conditions, a stepchild, adopted child, and illegitimate child.

"Parent" includes a parent, grandparent, and step-parent, either of the person in the service or of the spouse.

"Brother" and "sister" include brothers and sisters of the half blood as well as those of the whole blood, stepbrothers and stepsisters, and brothers and sisters through adoption.

The bureau on request shall furnish information to and act for persons in service with respect to insurance as may be prescribed by regulation, and may on request keep records of policies, companies, etc. (Sec. 24.)

Punishment provided for perjury or fraud. (Secs. 25-26.)

\section{Aluotments and Family Allowances}

(Applies to enlisted men, not to officers.)

$$
\text { Allotment of Pay (Sec. 201) }
$$

Allotment of pay, compulsory as to wife (divorced wife in certain cases), compulsory as to child, voluntary as to other persons. 


\section{FEDERAL MILITARY PENSIONS IN THE UNITED STATES}

Monthly compulsory allotment shall be in an amount equal to family allowances hereinafter specified but not more than one-half pay, or less than $\$ 15$.

The enlisted man may allot any proportion or amount of his pay in addition to the compulsory allotment for such purposes and persons as he may direct, subject to regulations. (Sec. 202.)

The Secretary of War and the Secretary of Navy may require that any proportion of one-half pay which is not allotted shall be deposited in the military and naval pay deposit fund for the benefit of the man. (Sec. 203.)

Compulsory allotment may be waived on written consent of wife, supported by evidence of her ability to support herself and children. (Sec. 201.)

Compulsory allotment may be excused for good cause shown, subject to regulations. (Sec. 201.)

Family Allowance (Sec. 204)

A family allowance not to exceed $\$ 50$, in addition to pay allotted by the man, shall be paid by the United States.

Family allowance shall be paid upon application, which may be made by the man, or made by or in behalf of the beneficiary.

No family allowance shall be made for any period preceding November 1, 1917.

Family allowance will be paid from the time of enlistment, but ceases one month after the termination of the war, or at death in, or one month after discharge from the service.

Beneficiaries Entritled to Family Allowance, and Schedules

If the enlisted person is a man:

Class A. Wife, child, or children:

(a) If there be a wife but no child, $\$ 15$.

(b) If there be a wife and one child, $\$ 25$.

(c) If there be a wife and two children, $\$ 32.50$, with $\$ 5$ per month additional for each additional child.

(d) If there be no wife, but one child, $\$ 5$.

(e) If there be no wife, but two children, $\$ 12.50$.

(f) If there be no wife, but three children, $\$ 20$.

(g) If there be no wife, but four children, $\$ 30$, with $\$ 5$ per month additional for each additional child.

Class B. Grandchild, parent, brother or sister :

(a) If there be one parent, $\$ 10$.

(b) If there be two parents, $\$ 20$.

(c) For each grandchild, brother, sister, and additional parent, $\$ \mathbf{5}$.

If the enlisted person is a woman:

Class A. (None.)

Class B. Child, grandchild, parent, brother or sister:

(a) If there be one parent, $\$ 10$.

(b) If there be two parents, $\$ 20$. 
(c) For each grandchild, brother, sister, and additional parent, $\$ 5$.

(d) If there be one child, $\$ 5$.

(e) If there be two children, $\$ 12.50$

( $f$ ) If there be three children, $\$ 20$.

( $g$ ) If there be four children, $\$ 30$, with $\$ 5$ per month additional for each additional child.

Family allowances for Class A shall be paid only if and while a compulsory allotment is made to a member or members of such class. (Sec. 205.)

SEC. 206. That family allowances to members of Class B shall be granted only if and while the member is dependent in whole or in part on the enlisted man, and then only if and while the enlisted man makes a monthly allotment of his pay for such member or members equal to the amount of the monthly family allowance as hereinabove specified, except that-

(a) The maximum monthly allotment so required to be made to members of Class B shall be one-half of his pay.

(b) If he is making no allotment to a member of Class $A$, the minimum monthly allotment so designated to be made to members of Class $B$ shall be $\$ 15$ per month.

(c) If he is making the compulsory allotment to a member of Class A, the minimum monthly allotment so designated to be made to members of Class B shall be one-seventh of his pay, but not less than $\$ 5$ per month.

On the enlisted man's application, or otherwise for good cause shown, exemption from this additional allotment under Class B as a condition to the allowance may be granted, upon such conditions as may be prescribed by regulations.

SEC. 207. That the amount of the family allowance to members of Class B shall be subject to each of the following limitations:

(a) If an allowance is paid to one or more beneficiaries of Class $\mathrm{A}$, the total allowance to be paid to the beneficiaries of Class $B$ shall not exceed the difference between the allowance paid to the beneficiaries of Class $\mathrm{A}$ and the sum of $\$ 50$.

(b) The total monthly allowance to beneficiaries of Class B added to the enlisted man's monthly allotment to them shall not exceed the average sum habitually contributed by him to their support monthly during the period of dependency but not exceeding a year immediately preceding his enlistment or the enactment of this amendatory act.

SEC. 208. That as between the members of Class $A$ and as between the members of Class $B$, the amount of the allotment and family allowance shall be apportioned as may be prescribed by regulations.

SEC. 209. The War and Navy Departments, respectively, shall pay over to the Treasury Department monthly the entire amount of such allotments for distribution to the beneficiaries, and the allotments and family allowances shall be paid by the bureau to or for the beneficiaries. 


\section{FEDERAL MILITARY PENSIONS IN THE UNITED STATES}

SEC. 210. That upon receipt of any application for family allowance the Commissioner shall make all proper investigations and shall make an award, on the basis of which award the amount of the allotments to be made by the man shall be certified to the War Department or Navy Department, as may be proper. Whenever the Commissioner shall have reason to believe that an allowance has been improperly made or that the conditions have changed, he shall investigate or reinvestigate and may modify the award. The amount of each monthly allotment and allowance shall be determined according to the conditions then existing.

The Commissioner after investigation shall make an award, on which the amount of allotments shall be determined.

The Commissioner shall have continuing jurisdiction over his awards.

The amount of each monthly allotment and allowance shall be determined according to the conditions then existing. (Sec. 210.)

Compensation for Death or Disability (Sec. 300)

Compensation is payable to officers and enlisted men and to members of the Army Nurse Corps or of the Navy Nurse Corps when employed in active service under the War or Navy Department.

Compensation shall be payable for death or disability resulting from personal injury suffered or disease contracted in line of duty, unless caused by the person's own wilful misconduct.

The cost of compensation shall be paid by the United States without contributions from the persons protected.

\section{Compensation in Case of Death (Sec. 301) TO FAMILY}

The only persons entitled to receive compensation in case of death are the widow, children, and dependent widowed mother of the deceased.

The monthly sums payable in each case are stated and are not based upon the pay of the deceased.

(a) For a widow alone, $\$ 25$.

(b) For a widow and one child, $\$ 35$.

(c) For a widow and two children, $\$ 47.50$, with $\$ 5$ for each additional child up to two.

(d) If there be no widow, then for one child, $\$ 20$.

(e) For two children, $\$ 30$.

(f) For three children, $\$ 40$, with $\$ 5$ for each additional child up to two.

(g) For a widowed mother, $\$ 20$. The amount payable under this subdivision shall not be greater than a sum which, when added to the total amount payable to the widow and children, gives $\$ 75$.

Compensation to a widow or widowed mother shall continue until death or remarriage.

Compensation to a child shall cease at the age of 18 , or at marriage, unless the child is incompetent. 
If the death occur before discharge or resignation from service, the United States shall pay for burial expenses and the return of body to his home a sum not to exceed $\$ 100$, as may be fixed by regulations.

\section{Compensation in Case of Total Disability (Sec. 302)}

During the continuance of total disability, monthly compensation shall be paid to the injured person.

The amounts payable monthly are stated in this section; they are not based upon the pay of the injured person.

(a) If he has neither wife nor child living, $\$ 30$.

(b) If he has a wife but no child living, $\$ 45$.

(c) If he has a wife and one child living, $\$ 55$.

(d) If he has a wife and two children living, $\$ 65$.

(e) If he has a wife and three or more children living, $\$ 75$.

( $f$ ) If he has no wife but one child living, $\$ 40$, with $\$ 10$ for each additional child up to two.

( $g$ ) If he has a widowed mother dependent upon him for support, then in addition to the above amounts, $\$ 10$.

To an injured person who is totally disabled and in addition so helpless as to be in constant need of a nurse or attendant, such additional sum shall be paid, but not exceeding $\$ 20$ per month, as the director may deem reasonable: Provided, however, That for the loss of both feet or both hands or both eyes, or for becoming totally blind or helpless and permanently bedridden from causes occurring in the line of duty in the service of the United States, the rate of compensation shall be $\$ 100$ per month: Provided further, That no allowance shall be made for nurse or attendant.

\section{Compensation in Case of Partial Disability}

The amount of compensation in case of partial disability is a percentage of the compensation provided in case of total disability.

The percentage is equal to the reduction in earning capacity resulting from the injury.

A schedule of disability ratings shall be adopted, based upon average impairments of earning capacity in civil occupations resulting from specific injuries of a permanent nature.

\section{Provisions Relating to Disability}

In addition to compensation the United States shall furnish medical, surgical, and hospital services, and such supplies, including artificial limbs, trusses, etc., as the director may determine to be useful and reasonably necessary.

Provision is made for frequent examinations of the disabled.

Every person in receipt of compensation shall submit to reasonable treatment. (Sec. 303.) 


\section{FEDERAL MILITARY PENSIONS IN THE UNITED STATES}

Courses of rehabilitation and reeducation may be provided by the United States. If the following of such a course prevents the injured person from earning a living he must (under penalty of suspension of compensation during refusal) enlist in the service, in which case he receives full pay and his family receives allowances and allotments as above provided, in lieu of compensation while the course continues. (Sec. 304.)

The bureau has continuing jurisdiction over compensation cases; (Sec. 305 ), and may at any time review an award and, in accordance with the fact, end, diminish, increase, or make an award.

\section{Conditions Governing Compensation}

Death or disability, to be compensable, must occur while in the service or within one year after discharge or resignation.

Except that, if the injured person, within one year after leaving the service, shall undergo a medical examination and obtain a certificate that he is suffering from an injury likely to cause death or disability, compensation shall be payable whenever death or disability resulting from such injury occurs. (Sec. 306.)

Compensation shall not be payable for death in the course of the service until the death be officially recorded in the department under which the person may be serving.

No compensation shall be payable for a period in which the man has been reported missing and a family allowance has been paid for him. (Sec. 307.)

Death inflicted as a punishment for a crime or military offense is not compensable unless it is inflicted by the enemy.

Dismissal or dishonorable discharge is a bar to any compensation. (Sec. 308.)

Compensation is not assignable and is exempt from attachment, execution, and from all taxation. (Sec. 311.)

Compensation shall not be paid while the person is in receipt of service or retirement pay.

Except as rights have heretofore accrued, existing laws providing payments in the event of death in the service (as six months pay) and existing pension laws shall not be applicable to persons now or hereafter in the service.

Compensation to members of the Army Nurse Corps or of the Navy Nurse Corps is in lieu of compensation under the act of September 7, 1916. (Sec. 312.)

\section{When Claim Must Be Filed}

In case of disability, claim must be filed within five years after discharge or resignation from the service; or, if the disability occur after leaving the service, within five years after the beginning of disability.

In case of death during the service, the claim must be filed within five years after the death is officially recorded in the department in which the person is serving.

In case of death after discharge or resignation from the service, the claim must be filed within five years after death. (Sec. 309.) 
No compensation shall be payable for any period more than two years prior to the date of claim. (Sec. 310.)

\section{INSURANCE}

Insurance against death or total permanent disability is provided by the United States and made available to every officer and enlisted man and to members of the Army Nurse Corps and Navy Nurse Corps when employed in active service under the War and Navy Departments.

Insurance must be in multiples of $\$ 500$ and not less than $\$ 1,000$ or more than $\$ 10,000$.

Insurance must be granted upon application to, and payment of premium to, the bureau.

Insurance must be granted without medical examination. (Sec. 400.)

Insurance must be applied for within 120 days after enlistment and before discharge or resignation from the service.

Persons who are in active service at the time of the publication of terms and conditions may apply at any time within 120 days thereafter, while in service. (This period expires February 12, 1918.)

\section{Automatic Insurance}

Any person in active service on or after the 6th of April, 1917, is insured automatically until February 12, 1918, unless he has applied for insurance to take effect at an earlier date.

The protection thus given is against death and against total permanent disability occurring, while in active service, from April 6, 1917, to February 12 , 1918, inclusive.

If the insured person die, without having become so disabled, during the period stated, monthly instalments of $\$ 25$ each will be paid his wife, child, or widowed mother. These instalments are payable to the wife during her widowhood or to the child or widowed mother while they survive him, but not more than 240 instalments shall be so paid.

If the insured person becomes totally and permanently disabled during the period stated he will receive an income payable in monthly instalments of $\$ 25$ each during disability. If he die, like instalments are payable to the wife during her widowhood or to the child or widowed mother while they survive him, but not more than 240 instalments less the number of instalments that may have been paid to the insured while disabled shall be so paid. (Sec. 401.)

\section{Insurance DetaIIs}

Insurance shall not be assignable or subject to claims of creditors of the insured or of the beneficiaries.

Insurance shall be payable only to a wife or husband, child, grandchild, parent, brother, or sister of the insured or to himself. (Automatic insurance is payable only to a wife, child, or widowed mother.) 


\section{FEDERAL MILITARY PENSIONS IN THE UNITED STATES}

Insurance shall be payable in 240 monthly instalments, except that in the case of total permanent disability monthly instalments will be continued throughout the duration of disability.

Provisions for endowment, continuous instalments, surrender values, dividends, etc., as may be reasonable, may be provided by regulation.

The insured has the right to change the beneficiary without consent, but only within the permitted class.

If no beneficiary within the permitted class be designated by the insured, either in his lifetime or by his last will and testament, or if the designated beneficiary does not survive the insured, the insurance (or if any beneficiary survives the insured but does not receive all the instalments, then the remaining instalments) shall be payable to such person or persons, within the permitted class of beneficiaries, as would under the laws of the state of the residence of the insured be entitled to his personal property in case of intestacy. If no such person survive the insured, then there shall be paid to the estate of the insured an amount equal to the reserve value, if any, of the insurance at the time of his death. (Sec. 402.)

The United States shall bear the expense of administration and the excess mortality and disability cost resulting from hazards of war.

Premium rates shall be net rates, based upon the American Experience Table of Mortality, and $3 \frac{1}{2}$ per cent interest. Such rates do not include any provision for expenses. (Sec. 403.)

During the period of the war and for five years thereafter, unless sooner converted, the insurance shall be term insurance for successive terms of one year each.

For five years after the termination of the war the insured shall have the right to convert this term insurance into any of the usual forms of insurance at the net premium rate for such forms of insurance.

No medical examination can be required as a condition of converting the insurance.

Unless the privilege of conversion is exercised the insurance can not be continued after the expiration of the five-year period.

To carry out the privilege of conversion, ordinary life insurance, 20-payment life insurance, endowment maturing at age 62 , and other usual forms of insurance shall be provided.

Premiums shall not be required for more than one month in advance and may be deducted from the pay or deposit of the insured.

The instant you sign your application, the insurance is in force.

The insurance is issued at monthly rates for the age (nearest birthday) of the insured when the insurance goes into effect, increasing annually upon the anniversary of the policy to the rate for an age one year higher, as per the following table of rates: 
Monthly Premiums for Each $\$ 1,000$ of Insurance

(Each $\$ 1,000$ of insurance yields $\$ 5.75$ per month for 240 months)

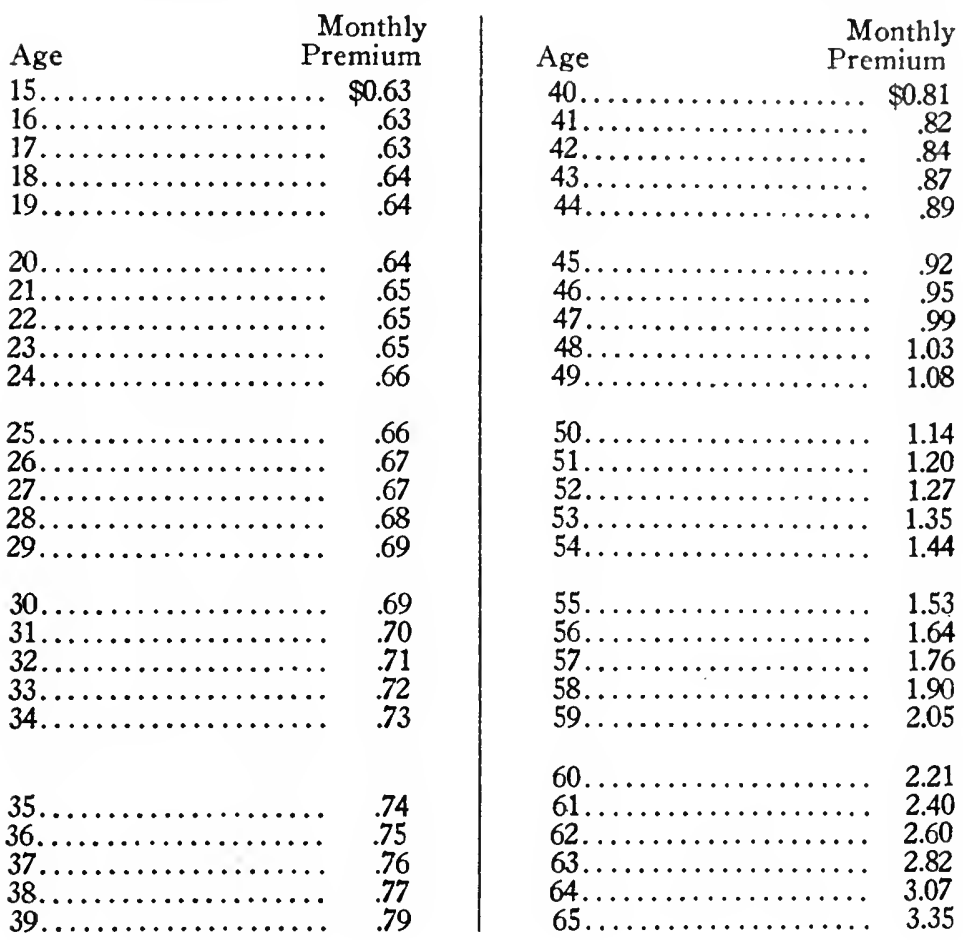




\section{BIBLIOGRAPHICAL NOTE}

Footnotes have been used freely throughout this volume to indicate all important sources and secondary works used. Naturally most of the material for the study of a subject of this kind is to be found in the records and public documents of the various departments of the Government of the United States. Valuable supplementary information is contained in the records of organizations of former soldiers, in publications issued by claim agents and pension attorneys, in newspaper and magazine articles reflecting current opinion and criticism, in the platforms of political parties, in the writings of statesmen and publicists who have had experience with the matter of pensions, in the few dependable secondary works on the subject, and in general writings on the history and economic and social problems of the United States.

Legislative discussion and action on military pensions are recorded in the Annals of Congress, the Register of Debates in Congress, Congressional Globe, Congressional Record, Senate Journal, House Journal, Senate Reports of Committees, and House Reports of Committees. Extended and particularly illuminating investigations of the pension system were made by committees in the Twenty-third, the Forty-sixth, the Forty-eighth, and the Fifty-second Congresses. Reports of these and other committee investigations are exactly cited at appropriate places in the text. The pension laws of Congress are of course to be found in the United States Statutes at Large.

Executive papers and reports on pensions (except special and technical publications of the Bureau of Pensions and the Department of the Interior) are for the most part to be found in the Executive Documents of the Senate or House of Representatives. These are easily accessible in the set of Congressional documents in public depository libraries. Many documents and reports are also printed separately. The American State Papers (38 vols., Washington, 1832-1861) contain many papers of value to the investigator of the early history of the United States pension system. Prior to 1849 the Secretary of War was the cabinet officer generally in charge of the administration of the pension laws, and his annual reports are an important source of information. The Pension Office of the War Department was established in 1833 with a Commissioner of Pensions in charge. In 1849 the Pension Office became the Bureau of Pensions of the newly created Department of the Interior. The principal source of information with regard to the administration of the pension laws is the annual Report of the Commissioner of Pensions to the Secretary of the Interior with accompanying statistical tables and appendices. The annual Report of the Secretary of the Interior usually contains a summary of the pension report and sometimes important additional discussion and recommendations. Many special publications of the Department of the Interior and the Bureau of Pensions throw 
light upon the detailed interpretation and administration of the various laws. Works of this kind are the numerous editions of the Laze's of the United States Governing the Granting of Army and Navy Pensions together with Regulations Relating Thereto and the many volumes of Decisions of the Department of the Interior in Appealed Pension and Bounty-Land Claims: From time to time the Commissioner of Pensions has also prepared special reports on matters of current importance to be transmitted to Congress. The views of the Presidents of the United States on the pension policy of the government are frequently expressed in their annual messages to Congress.

At times important decisions affecting the pension system and the administration of the pension laws have been made by the judicial branch of the federal government. They are to be found in the official Reports of Cases Argued and Adjudged in the Supreme Court of the United States, and in the reports of cases adjudged in inferior federal courts.

For a knowledge of the efforts of the organized Civil War soldiers to promote pension legislation, an indispensable source is the set of Journals, etc., of the annual national encampments of the Grand Army of the Republic from 1878 to the present time. The Grand Army began to express an interest in pension matters in 1878 , and in 1881 organized a Committee on Pensions which thereafter represented the claims of the veterans and their dependent relatives before Congress and the President. The annual Journal contains the report of the Committee on Pensions, and the debates and resolutions of the national encampment.

The activities of claim agents in agitating for extravagant pension grants are best illustrated in the files of the National Tribune (Washington, D. C., 1877, to the present), a paper established in October, 1877, by George E. Lemon, who became the most powerful pension attorney in Washington. The National Tribune was at first a monthly and later a weekly. It secured official endorsement from the Grand Army of the Republic, systematically promoted the organization of Grand Army posts, gained a very large national circulation, and urged the pensioners and claimants to use their votes to force parties and candidates to favor pension legislation. There have been from time to time many other soldiers' and claim agents' publications, but of less circulation and influence.

In the preparation of this work, several hundred newspaper and magazine articles, editorials, sermons, published letters, public addresses, and pamphlets have been examined. For the most part they are of value as reflecting various phases of current opinion regarding the pension system rather than for trustworthy information. A considerable proportion of such material has practically no permanent value. The best founded and most damaging attacks upon the evils of the pension system that have appeared in any magazine in recent years may be found in World's Work for 1910, 1911, and 1912. Under the title "The Pension Carnival," William Bayard Hale (assisted by Albert Sonnichsen and Lloyd Dorsey Willis) wrote a series of six illustrated articles on the pension system in successive numbers of World's Work from October, 1910, to March, 1911. These articles were written in popular 


\section{FEDERAL MILITARY PENSIONS IN THE UNITED STATES}

style, exposed the weak points in the pension system, and gave numerous concrete examples of abuses. Later, General Charles Francis Adams, who served with distinction in the Union army during the Civil War, wrote for World's Work a series of three articles, published in December, 1911, January, 1912, and February, 1912, under the general title "Pensions-Worse and More of Them." These articles were afterward published by World's Work in a pamphlet entitled The Civil-War Pension Lack-of-System. General Adams's severe but warranted arraignment of the federal pension system gained force from his national reputation as historian and publicist.

It is hoped that other material used in the preparation of this book is sufficiently indicated in the numerous footnotes. However, the following volumes deserve especial mention as of importance in the study of the United States pension system:

Bureau of Pensions, Its Officers and Their Duties. The Manner in Which the Work of Adjudicating Claims Is Performed. Prepared by direction and under the supervision of the Commissioner. Washington, 1893. An untechnical account of the organization of the Bureau of Pensions and its methods of doing business.

Glasson, William Henry. History of Military Pension Legislation in the United States. Columbia University Studies in History, Economics and Public Law. New York, 1900.

Governmental Provisions in the United States and Foreign Countries for Members of the Military Forces and Their Dependents. Prepared in the Children's Bureau of the Department of Labor by a number of investigators under the direction of Captain S. Herbert Wolfe. Washington, 1917. A useful compilation of facts with regard to the military pension provisions of the United States and the leading foreign countries. There are also many diagrams, statistical tables, and references to sources of information.

Oliver, John William. History of the Civil War Military Pensions, I86I1885. Bulletin of the University of Wisconsin, No. 844. Madison, Wisconsin, 1917. A detailed and valuable study of the United States pension system between 1861 and 1885 .

A Treatise on the Practice of the Pension Bureau Governing the Adjudication of Army and Navy Pensions. Compiled by order of the Commissioner of Pensions under the authority of the Secretary of the Interior. Washington, 1898. This work is invaluable to one who wishes to understand the actual procedure at the time in presenting and establishing the validity of claims before the Bureau of Pensions. 


\section{INDEX}

Abuses, see rrauds and abuses.

Act of June 27, 1890, see Disability Pension Act of 1890 .

Act of 1912 (age and service), provisions of, 258; effect of, 259; activities of G. A. R. in securing, 260 .

Adams, John, 19, 20.

Adams, John Quincy, 51, 73, 85.

Adams, Samuel, 48.

Administration: by states, 22, 23; by Secretary of the Treasury, 51 ; by Secretary of War, $51,75,85$; in circuit courts, 56 ; by Secretary of the Interior, 118, 128, $135,227,228$; cost of, 270

Age-and-service pensions: Mexican War, $117,118,247,250,259$; Civil War, 126, 232, 243, 246, 247, 249, 258, 259, 260.

Agents, claim, see Attorneys and agents.

Application, date of, as affecting pensions, $126,152$.

Army Nurse Corps, insurance for, 292.

Army pension fund, proposed by Commissioner Barrett, 105.

Arrears, early claims for, 21; unfavorable report on, 61; allowance of, under act of $1862,93,152$; amounts paid to navy under act of 1837, 104; provisions in Consolidation Act, 140; agitation for, 150; provisions of proposed measure, 151; provisions in various acts, 152; five-year limitation discussed, 152-155; action in Congress, 156-163; agitation for, among claim agents, 149,156, 157; provisions of Arrears Act, 164, 165; Commissioner Arrears Act, 164, 165; Commissioner frauds, 168, 175; appropriations for, 169 . 172 ; agents' profits, 174 ; expenditures, $175,176,177,178$; efforts to repeal limitation, 186, 199; partial repeal, 200; statistics, 203.

Arrears legislation, agitation for, 150; Act of July 27, 1868, 152; - Consolidation Act, 153; Arrears Act, Jan. 25, 1879, 163; Arrears Appropriation Act, 177; act of June 7, 1888, 200.

Attorneys and agents, activities of, for War of 1812 pensions, 110 ; methods of, criticised by Commissioner Bentley, 149; agitation of, for increased pensions, 149 $150,156,157$; barred from compensation in arrears application, 158, 165; evasions and violations by, 166; profits under Arrears Act, 174, 178; Commisunder Arrears Act, 174, 178; Commiscised in Congress, 194, 214, 215-217.

Attorneys' fees, under general law, 128 ; under act of 1890, 235; under Arrears Act, 158, 165.

Attorneys General, actions of: Randolph, 58, 59; Bradford, 59.

Aviation, double pension for death or disability caused by, 143 .

Antomatic increase in pension, 260.

Automatic insurance, 293.

Bakeman, Dan'l F., last Revolutionary survivor, 93.

Baker, James H., Commissioner of Pensions, reports of, concerning: servicepensions, 95 , rates for specific disabilities,
131, codification of pension laws, 132, claims for disease, 153 .

Barrett, Joseph H., Commissioner of Pensions, report of, on navy pension fund, 104; army pension fund proposed by, 105; comments of, on law of 1862, 128, 129 .

Beck, Senator James B., argument of, for repeal of Arrears Act, 177, note 1; publication of pension list called for by, 182 ; speech of, against disability pension bill, 220; discussion of tariff reform, 222 .

Bell, John, service-pensions opposed by. 79 .

Bentley, James A., Commissioner of Pensions, reports of, concerning: methods of pension agents, 149, 178; estimated cost of arrears bill, 163,167, 175; attorneys' fees, 166 , note 1 ; frauds, 168 , 175,176 ; attack on, by National Tribune, 178; investigation of administration of, 179 .

Bibliographical Note, 296.

Black, Gen. John C. Commissioner of Pensions, report of, on classified disabilities, 138; statement of, on expenditure for arrears up to $1885,177,199$; appointment of, 198; recommendations and estimates of, 199, 200; war record of, 224; special pension, 224; later positions, 224 , note 4 ; criticism, 224, note 5; recommendations as commander-in-chief, G. A. R., 248; record as Commissioner, 244.

Blaine, James G., nominated on soldiers ticket, 190.

Bland, Col. Theodoric, proposals for benefit of officers presented by, 24.

Bloomfield, Gen. Joseph, report of, to House of Representatives on limited service-pension bill, 1818, 65 .

Bouldin, Representative, pensions opposed by, 79,83 .

Bradford, Wm., attorney general, action of, in case of Yale Todd, 59.

Bragg, Gen. E. S., speech of, supporting veto of Dependent Pension Bill, 214; arvument of, with Representative Henderson, 215.

Brothers, provision for, under general law system, 139, 140; under War Insurance Law, 287, 289.

Buckner, Senator, opposition of, to servicepensions, 81 .

Calhoun John C. Secretary of War, reports of, concerning: frauds, 70 , number and cost of pensions in 1823, 73, 74

Cannon, Joseph, speech of, favoring ex. penditures for pensions, 222; Sherwood bill supported by, 257 .

Cass, Lewis, Secretary of War, cost ot pensions in 1833, reported by, 83; Penpensions Office recommended by, 85 ; frands discussed by, 89 .

Charles II, Chelsea Hospital established by, 11 .

Chelsea Hospital, established, 11; outpensioners, 12

Cincinnati, Society of, see Society of the Cincinnati. 
Circuit courts, 19, 50; duties of, under act of 1792,56 ; protests by, 56, 57; refusal to act, 57 .

Civil War, principal legislation of: general law system founded by act of 1862,125 ; act of July 27, 1868, 152; Consolidation Act, 132; Arrears Act, 163; Arrears Appropriation Act, 177; Disability Pension Act, 233; widows' pension act, 251 ; act of 1912, 258; private acts, 275 .

Claim agents, see Attorneys and agents.

Clay, llenry, claims of Revolutionary soldiers, advocated by, 81 .

Cleveland, Grover, vetoes of discusscd, $117,192,210,278$; message of, recommending consideration, 207, 208; hostility to, $217,222,278$, note 2 ; nominated for re-election, 223; defeat of, 225; special acts during administration of, 279 .

Codification of pension laws, recommended by Commissioner Baker, 132 .

Colonial pension laws: Virginia Company, 13; Virginia Royal Colony, 13; Plymouth Colony, 14; Massachusetts Bay Colony, 14; Maryland, 15; New York, 16; Rhode Island, 16.

Combination of slight disabilities, 239; act providing for, 242 .

Commanders-in-Chief, G, A, R pension activities of: Beath, 189; Black, 248; Brown, 250; Fairchild, 212; Merrill, 188; Robinson, 160; Tanner, 181, 188, 218, note 1, 248; Torrance, 245; Van Jervoort, $183,188,196,217$, note 1 ; Wagner, 188 .

Commissioner of Pensions, appointment of, recommended, 86 ; first appointee, 87 ; salary of (1833), 86; rate fixing powers of, $135,239,240,249$

Commissioners of Pensions, reports, recom mendations, etc., of: Baker, 95, 131, 132, 153; Barrett, 104, 105, 129; Black, 138 $177,198,199,200$; Bentley, 149, 163, 166 , note $1,167,168,174,175,176,178$, 179, 180; Davenport, 259; Dudley, 181 182 , 188, note 3, 190, 197, 198; Edwards, 88; Evans, 201, 241.246; Lochren, 240, 241; Raum, 228, 237, 240, 241; Tanner. $226,227,228$; Ware, 246.

Committee on Pensions, G. A. R., recom mended, 181; appointed, 186; program of pension legislation prepared by, 188 memorial to Congress, 189; official letter of, asking for petitions to Congress, 212; $M$ anderson bill, endorsed by, $220 ; \mathrm{C}$. C. Matson arraigned by, 221; calls on Har rison, 226; disability bill prepared by, in 1889, 229; appears before Congress on Act of 1890,232 ; act of 1890 approved by, 233; action of, in behalf of service law, 246; increase in widows' pension advocated by, 250; activities of, in connection with act of $1912,254,260$; Mc Cumber bill endorsed by, 257.

Commutation Act $(1783)$, proposed by Eliphalet Dyer, 41 ; provisions of, 41 ; hos tility to, 43, 44, 47; upheld by Noah WebSter, 46, 48; report on, by Secretary of War, 49.

Commutation of half pay, application for, 35; onposed by: Connecticut, 38, 44, 45, 46, 47; Massachusetts, 35, 43, 47; New Hamnshire, 40; New Jersey, 40; Rhode Island, 38, 39, 40; debates on, 39; number entitled to, 49 .

Commutation certificates, issued in 1784 49; provisions for redemption of, 50 ;
President John Quincy Adams' recommendations for payment of, 51 .

Conkling, Senator Roscoe, discussion by, concerning Arrears Act, 170 .

Consolidation Act (March 3, 1873), recommended by Commissioner Baker, 132; new provisions, 134; rate fixing power of Commissioner under, 135; provisions for widows and orphans, 140; five years' limitation, 153.

Continental' Congress, principal legislation of: first national pension law, Aug. 26, 1776,20 ; compromise measure, May 15, 1778 , 30; first national provision for widows and orphans, Aug. 24, 1780, 33; Commutation Act, March 22, 1783, 41; final resolutions, June $11,1788,22$.

Cost of pensions, see Expenditures; also, Statistical tables.

Cullom bill, 192

Cummings bill, 158.

Cummings, Representative Henry $\mathrm{J}$, connection of, with arrears bill, 158, 159, 165.

Cushing, Wm., Associate Justice, protest of, 56 .

Damon, Esther S., last widow of Revolutionary soldier, 94 .

Davenport, James L., Commissioner of Pensions, cost of act of 1912 estimated by, 259.

Davis, Jefferson, 171.

Davis, Senator, dependent pension bill introduced by, 230.

"Dependence clause" in pension legislation, $67,74,205,218,220,229,232,236$.

Dependent pension bill, introduced in House in 1887, 208; Senate bill more liberal, 209; vetoed by Cleveland, 210, 278; Cleveland's veto message on, 210-212.

Dependent relatives, see Relatives, dependent, provisions for.

Desertion, bar to pensions, 63; charge of, removed by special acts, 276, note 1 .

Development of invalid-pension system, 129.

Dimmick, Capt. R. A., lobbying activities of, 157 , note 1,159 , note $2,161,166$, note 1 .

Disabilities, specific, see Specific disabilities.

Disability Pension Act of 1890, advocated by President Harrison, 229; introduced by Senator Davis, 230; passed by Senate, 231 ; substitute bill passed by House 232; Conference Committee's bill signed June 27, 1890, 233; cost of, estimated 233 ; provisions of, 234,235 ; objectionable features of, 236; expenditures under, 238, 252, 270; development of system under, 262; most costly pension law, 270 .

Disability without regard to origin, pension for, 204, 210, 270 .

Disbursements per capita among states, 1910 , map showing, 268; amounts of, 269.

Diseases, rates for, 136; classification of, 138; pensions for, regardless of origin, $204,210,270$.

Disloyalty, 111, 117, 127, note 1 .

Distribution in states of pensions, per capita, 267, 269; map showing, 268 .

Divorce, effect of, on widows' pensions, $142,261$.

Dollar-a-day pension, 253.

Double pension for death or disability from aviation duty, 143. 
Duane, James, protest of, 56 .

Dudley, Col. W. W., appointed Commissioner of Pensions, 181; report of, on cost of arrears, 182; views of, on pension legislation, 188; administration of, attacked, 188, note 3 ; favorable comment of, on Warner bill, 190; activities of, in elections, 197, 198.

Dyer, Eliphalet, adoption of commutation proposition prevented by, 41 ; new plan offered by, 41.

Edwards, James L., first Commissioner of Pensions, 87; report of frauds by, 88 .

Elizabeth, Queen of England, pensions during reign of, 9 .

Employes of Pension Bureau, 87; political activities of, 198; frauds among, 199; reratings of, 227; temporary increases in force of, 259.

English legislation: first law (1592-3), 9; statute of 1601,10 ; act of 1662,11 .

English pensions: in Elizabeth's reign, 9; during Commonwealth and after Restoration, 11; half pay, 12; see also Chelsea Hospital.

Evans, H. Clay, Commissioner of Pensions, report of, on abuses, 201 ; on administration of act of $1890,241,242$; interpretation by, of act of 1900,243 ; instructions by, to examining surgeons, 243 ruling by, on widows' pensions, 244; G. A. R.'s attack on, 244 , note 1, 245 resignation of, 245; appointed consu general at London, 246.

Evils of pension system, 147, 237, 239.

Expansion of pension system, persons in terested in, 266; reasons for indiffer ence to, 269.

Expenditure, greatest annual, 259; effect of, in different parts of the country, 267.

Expenditures: Revolutionary War, 1792, 23: 1816,$64 ; 1818-22,74 ; 1823,75 ; 1833,83$; 1834,89 ; total, 95, 96; regular navy pensions, 106; War of 1812, 112, 113; Indian Wars, 115; Mexican War, 119; Civil War, 1870-1916, 123; 1861, 124; under general law, 144; 1873-78, 148; arrears in 1872,152 , note $2 ; 1880,175$; $1855,177,199 ; 1879-82,182 ; 1877-99$, 203 ; under act of $1890,238,252,270$; 1907,251 ; 1908-09, 252; 1912, 259; $\max -$ imum in 1913, 259; 1890-1917, 262; War with Spain and Philippine Insurrection, 145; regular army pensions, 146; all expenditures since 1865,270 ; from 1891 to $1907 ; 270$; from 1866 to 1917,273 ; all wars, 274; special acts, 279,280 .

Fathers, provision for, under general law system, 139; under War Insurance Law, 288.

Federal judges, protests of, 56,57 ; duties, 60.

Fees of pension attorneys, 128, 158, 165, 166 , note $1 ; 235$.

Financial effects of pension system, 267274.

First general law under the Constitution, 55

First law for widows, 33

First national pension law, 20.

First service-pension, proposed by President Monroe, 65; speech by Senator Wm. Smith opposing, 66; provisions of, 67; abuses and frauds, 68 ; opposition to, 68 ; defense of, 69 .
Fitzgerald, N. W., claim agent and editor of Citizen Soldier, 156, 166, note 1, 216 note 1.

Five-year limitation of acts of 1868 and $1873,152,153$; application to widows' claims, 154; hypothetical case, 155; efforts to repeal, 186, 187, 199; partial repeal, 200.

Foot, Senator, connection of, with Revolutionary service-pensions, 80,83 .

Frauds and abuses: under act of 1818 , $68-71$; in 1834,87 ; Commissioner Edwards' report on, 88; recommendations and discussion, 89-91; special agent appointed to detect and prosecute, 128; Commissioner Bentley's efforts to prevent, 168; under Arrears Act, 168, 176; among examiners and employes, 199; under act of 1888, 202.

G. A. R. Pension Committee, see Committee on Pensions, G. A. R.

G. A. R., first activities of, regarding pensions, 160,181 ; non-partisanship of, advocated, 183; representation of, in Congress, 186; attitude of, concerning service-pensions, 205; hostility of, toward President Cleveland, 217; criticized by Senator Vest, 220, note 4; Tanner approved by, 226-229, note 1 ; act of 1890 , approved by, 233 ; widows' pensions asked for by, 244; activities for service-pensions, 246, 249,254, 260; methods of, described by Gen. Sherwood, 255 ; present condition of, 264.

Garfield, Gen. James A., pension appropriation bill, 1872 , explained by, 148 .

General law system, founded, 125; rates under, 126; provisions for widows and dependent relatives, $125-127,139-142,144$; general results of, 128,129 ; provisions for specific disabilities, 130 ; for diseases, 136; applications under, 143; statistics, $144,271,272$; decrease of pensions under, 272 .

General law widows and dependent relatives, 126, 139.

Gorman, Senator Arthur P., act of 1890 discussed by, 233 .

Grant, Ulysses S., special pension acts vetoed by, 277

Greene, Nathanael, correspondence with John Adams urging disability pensions, $19,20$.

Grosvenor, Gen. C. H., member of G. A. R. Committee on Pensions, 188; nominated to Congress, 196 , note 3 .

Half pay: in England, 12, 13; provision made by Virginia and Pennsylvania, 18; first national provision, 20; paid by states, 22; arrears paid by federal government, 23 ; restrictions and limitations, 23; opposition to, 28, 35; compromise measure, 29; promised for life, 34 ; number entitled to, 49 ; claims finally settled, 51; granted widows and minor children, $99,101,108$; prize money deducted from, 100; allowance for age and infirmity in navy, 105. See also Washington, George, and Commutation of half pay.

Harrison, Benjamin, act of June 27, 1890 , approved by, 193; presidential nomination of, 223; ante-election promises of, 224; election of, 225; G. A. R. Pension 
Committec ealls on, 226; Corp. Tanner appointed Commissioner of l'ensions by, 226; comments of, in accepting Corp. Tanner's resignation, 228; first annual message of, 229; disability pension bill signed by, 233; special pension acts during administration of, 279.

Hart, Albert Bushnell, comments of, on politics and pensions, 263.

Hawley, Gen. Joseph R., discussion of Arrears Act by, $177,178,184$; negative vote of, 192 .

Hayburn, William, case of, 57, 60 .

Hayes, Rutherford B., Arrears Act signed by, 163 ; criticism of, 163-164.

Hayne, Senator R, Y., speech of, reviewing legislation up to 1830,77 ; opposition of, to bill of 1832,81 .

Henderson, Representative D. B., 215, 232, note 2.

Hovey, Gen. A. P., activities of, in behalf of pensions, 205 , note 2,221 , note 4,225 231 .

Idiotic, insane or helpless child, pension to, $141,152,173,235,262,290$.

Increase in pension, automatic, 260.

Indian Wars: first provisions for survivors and widows, 114; service-pensions first granted, 1892, 115; increased benefits, 115; statistics, 115 .

Ingalls, Senator J. J., action of, on House arrears measure, 156; political pressure on, 161; champion of bill in Senate, 162 ; estimate of cost by, 167, 170; argument by, against repeal, 177, note 1; proposa of to repeal limitation in Arrears Act, 186,187 , notes 1 and $2,191,197$.

Insanity, idiocy or permanent helplessness, pensions in cases of, 141, 152, 173, 235, 262,290 .

Insurance law, 283

Invalid corps, provided for, 20 ; established, 21.

Invalid-pension system, development of, 129

Invalid-pensions: definition, 2; English origin, 9; colonial provisions, 13.17; first urged during Revolution by Nathanae Greene, 19; estimates of Revolutionary invalid-pension legislation, 95; regular army and navy, 98; War of 1812,108 ; army and navy, 98; War of 1812, 108 ; Civil War: first provision for, 124; general law pension system founded, 125 development of system, 129; Consolidation Act, 132; increase acts, 1888, 1895 135 ; provisions for aviation duty, 143 ; Spanish War and Philippine Insurrec tion, 145; regular army, 146; statistics, $144,145,146$. See also Specific disabili. ties; Arrears legislation.

Jackson, Andrew, regulation of $1828 \mathrm{re}-$ voked by, 77; pensions advocated by, 77 discussion by, of frauds, 89.

Jay, Chief Justice John, protest of, 56 .

Jones, Joseph, correspondence of, with Gien. Washington, 32, 36, 37.

Knox, Henry, Secretary of War, reports and recommendations of, 55 .

Iemon, Geo. E., 110, 150, 156, 162, 166 note $1,174,178,182,183,185$, note 1 ; note 1 , 1 , A. R. Committee on testimony before $G$. A. $R$. Comsions relative to Van Dervoort, 188 ; testimony before House investigating committce, 195,216 , note 1 ; attack on, in House, 214, 216; defense of Tanner. $218,226,228$, note 4 ; influence of, 265 . Lincoln, Gen. Benjamin, Secretary of War, letter of, to Washington relative to half pay, 36.

List of pensioners, kept by states, 22 ; ordered published, 70 ; called for by Sena. tor Beck, 182

Litigation, Hayburn's case, 58 ; U. S. v. Ferreira, 58, 60; U. S. v. Yale Todd, 60 .

Livingston, Gov. Wm., letter of, opposing officers' half pay, 28

Lochren, William, Commissioner of Pensions, readjudication of pensions by, 240 ; unpopularity of, with G. A. R., 241 .

Logan, Jobn A., nomination of, favored by soldiers, 190.

Long, Chas. D., case of, 240, note 1.

Loyalty, requirement for, 109, 111, 115, 127, 171.

McAdoo, Wm. Gibbs, connection of, with War Insurance Law of $1917,283$.

McCumber bill, 249; signed February 6, 1907,250 ; provisions of, 250; expenditures under, 252.

McCumber, Senator, service-and-age pension bill introduced by, 249; substitute for Sherwood bill introduced by, 256 .

McKinley, Wm., appeal in behalf of service-pensions presented by (in House of Representatives), 231 ; annual message of, concerning widows' pensions, 244 ; special pension acts passed during administration of, 279.

McPherson, Senator, comments of, on methods used in special pension legislation, 276.

Mack, Julian W., assistance of, in drafting War Insurance Law of 1917.

Madison, James, $37,38,39,40,41,48$.

Manderson, Senator, disability pension bill introduced by, 220; pension of, rerated, 227.

Map showing per capita disbursements by states, 1910,268

Marriage, date of, effect on widows' pension, 92,96 , note $1,110,140,141,235$, $251,260,261$

Matson, C. C. criticism of, by G. A. R Committee on Pensions, 221.

Matthews, Senator Stanley, petition regarding arrears presented by, 160,161

Maximum expenditure for pensions, 259.

Maximum number of pensioners enrolled. $259,266$.

Medical examiners, 137, 199.

Mercenary marriage to Civil $W$ ar veterans, 141.

Mexican border disturbances, provisions for, $136,143$.

Mexican War: regular perisions promised for disabilities, 116; provisions for widows and orphans, 116; age-and-service act, January 29, 1887, 117; increase acts, Tanuary, 1893, 118; September 8, 1916, 119; age-and-service pensions granted February 6, 1907, 118, 250, and May 11, 1912, 118, 259; statistics, 119

Military record, corrected by special legislation, 276, note 1 .

Militia, first pensioned, 63

Mills bill, 219, note $3,222,223$.

Monroe, James, recommendations in message of December, $181 \%, 65$

Morrill, Representative, action on de- 
pendent pension bill, 231; cost estimated by, 233 .

Morris, Gouverneur, correspondence of, with Washington, 30,31 ; motion to ex. tend half pay, 32 .

Mothers, first provided for, 127,128 ; provisions under general law system, 139; remarriage of, 142; under War Insurance Law, 288, 290.

National Intelligencer, defense of act of 1818 by, 71

National Tribune, description of, 150, note 1 ; first publication of, 156; comments of, on pension legislation, 167 , note $1,174,178,182,183,187$, 190; relations with G. A. R., 183, 184, 185 , note 1 , $186,188,189,255$; political activities of, $190,195,196,224$; reduction of taxes opposed by, 195, 218, 219; President Cleveland criticised by, 213, 217, 221; attacks upon, 214-216; influence of, 265 .

Naval Asylum (Philadelphia), 105, 106

Navy and privateer laws, 1799 and 1800, $100 ; 1813,1814,1816,1817,1824,101$; $1834,1837,103 ; 1862,104 ; 1864,105$.

Navy Nurse Corps, 292.

Navy pension fund, established, 100; amount of, in 1811, 100, in 1817, 101; history of, 101; administration of, 102 ; exhausted, 103; reestablished in 1862, 104; invested in United States securities, 105; supported Naval Asylum at Philadelphia, 106; increased in war with Spain, 106; present condition, 106

Newburgh addresses, 40.

Noble, John W., Secretary of the Interior, action of, concerning rerating of pensions, $227,228$.

Number on pension rolls: Revolutionary War, $1792,23,55 ; 1816,64 ; 1823,73$; 1833,$83 ; 1834,89,90$; résumé, 95; War of 1812,113 ; Indian Wars, 115; Mexican War, 119; Civil War, 1864, 129; 1872, 130; general law, 1865-1915, 144; War with Spain and Philippine Insurrection, 145; regular army pensions, 146; total, 1873-1878, 148; 1882, 182; 1908, 252 ; under act of 1912, 259; under act of 1890 and general law, 271; Civil War pensioners, 1907-1917, 272; total from 1866 to $1917,273$.

Nurses, service-pensions granted to, 235 , note 1; insurance for, 292.

Oath of allegiance, required by order of September 4, 1861, 127.

Officers and privates, Washington's defense of distinctions between, 43,52 .

Old age pensions: half pay in navy, 105; Mexican War, 118, 250; Civil War, 249, 250,260 ; various rates for, 250,258 , 260 ; widows, $260,264$.

Order of the Cincinnati, see Society of the Cincinnati.

Orders, Bureau of Pensions: No. 164, provisions of, 239; abrogated, 240 . No. 78 provisions of, 246 ; effect of, on act of 1890,247 ; superseded by act of February $6,1907,247$, note 1 ; favored by G. A. R., 248 .

Orphans, pension provisions for: Revolutionary War, 33, 91; regular army, 99; regular navy, 103; War of 1812,108 ; Indian Wars, 114; Mexican War, 116; Civil War, 125-127, 139, 141, 142, 192, 235, 262; War Insurance Law, 284, 287.
Parole evidence under Arrears Act, 165. Partial disability, proportionate rates for, 126.

Pension Bureau, administration of, 85 ; discretionary powers of, increased, 135; Congressional investigation of, 179; political activities of, $180,197,198$; reorganization of, 198 ; powers of, under act of 1890,239 .

Pension Committec of the G. A. R., see Cummittee on Pensions, G. A. R

Pension funds: army, 105; navy, j00-106; privateer, 107.

Pension Office, first planned for, 25; proposed by Washington, 26; recommended by Secretary Cass, 85 ; established in 1833, 86; see also Pension Bureau.

Pension planks in political platforms, Republican, i90, 223; Democratic, 195, 223. "Pensioners' Association," 160, 161, 221, note 4.

People, other than pensioners, having personal interest in maintenance of pension system, 266.

Permanent specific disabilities, statutory rates for (table), 133.

Philippine Insurrection, 145

Politics, effects of, on pension legislation, in Pension Bureau, 179, 180, 197, 198; among medical boards, 199; Dies' opinion on, 225; résumé, 262-266. See also G. A. R., and Committee on Pensions, G. A. R.

Poverty, effect of, on pensions, 74, 109, $118,243,244$.

Pratt, Senator, Consolidation Act explained by, 132 .

Premiums under War Insurance Law, 295.

Presidential campaigns, effect of, on pension legislation, $186,190,224,225$, $255,260,262$

Presidential recommendations: John Quincy Adams, 51; Monroe, 65; Jackson, 77, 89; Cleveland, 207; Harrison, 229.

Private pension acts, see Special pension legislation.

Privateer pension fund, 1812, 107

Prize money, deducted from half pay allowance, 100.

Prosecution for frauds, special agent appointed for, 128 .

Protective tariff, effect of, on pensions, 65 , $77,78,80,84,96,219,222,263$.

Randolph, Edmund Jennings, attorney general, 58, 59.

Rank, pensions graded as to, 126, 130, 139.

Rate fixing power of Commissioner of Pensions, 135, 239, 240, 249.

Rates, pension: Revolutionary War, 61, $63,64,67,98,108$; War of 1812, 109, 110; Indian Wars, 114, 115; Mexican War, 116-119; Civil War, 126, 129, 130, $132,134-141,165,172,208,234,235$, $237,242,247,250,252,260$; Aviation, 143; under War Insurance Law, 288, 295.

Raum, Green B., appointed Commissioner of Pensions by President Harrison, 228; relations of Geo. E. Lemon with, 228, note 4; Order No. 164 issued by, 239; order of, abrogated, 240; revision of rulings by, discontinued, 241 .

Record evidence, not required, 110.

Records, pension, furnished on payment of fee, 260. 
Reduction of pensions, 72,240 .

Regular army and navy pensions, history of, and legislation concerning, 98, 99.

Regular army pensions, 146.

Regular establishment pensions since 1904, 146.

Relatives, dependent, provisions for: general law, $125 \cdot 128,139,140$; aviation, 143; Spanish War and Philippine In. surrection, 145; under War Insurance Law, 284, 288-291.

Remarriage, effect of: on dependent mothers, $127,142,290$; on widows' pensions: War of 1812 , 111; Indian Wars, 115; Mexican, 117; Civil War, 127, 139, $142,235,261$; War Insurance Law, 290.

Remedial act of May 1, 1820, provisions of, 71. complaints concerning, 72 ; report on, by Secretary Calhoun, 74.

Rerating of pensions by Commissioner Tanner, 226, 227; action of Secretary of Interior, 227, 240; board of investigation appointed, 228; special cases: Frank A. Butts, 227, note 1; Senator Manderson, 227, note 2; Chas. D. Long, 240, note 1.

Restoration, application for, 74 ; provisions for, 111; of widows' pensions, 142, 261.

Restrictions on pensions to widows: remarriage, $110,115,117,127,139,142$, 261; disloyalty, 127; late marriage, 110 , $140 ;$ income, 243, 244

Retirement pay, 99

Retirement system, 99.

Revocation of pensions, 71,240

Revolution, principal laws pensioning soldiers of the (see also Continental Congress, principal legislation of): Invalid: general pension law, March 23, 1792, 55; objectionable sections repealed February $8,1793,60$; laws of 1803,1805 and 1806,62 ; act of April 25, 1808, 63; increase law, April 24, 1816, 64. Service: act of 1818,67 ; remedial act, May 1 , 1820,71 ; restoration act, March 1,1823 74 ; act of May $15,1828,51,76$; additional provisions, June $7,1832,81$; amendment of February 19, 1833, 82; amendment of February $19,1833,82$; February 27, 1865, 93. Widows: act of July 4,1836 ; 91,94 ; acts of 1868 and 1878,92 .

Rice, Representative, action of, regarding arrears, 158, 159.

Roll of pensioners, publication of, 70 ; furnished on payment of fee, 260 .

Roosevelt, Theodore, resignation of Commissioner Evans accepted by, 245; Eugene $F$. Ware appointed Commissioner of Pensions by, 246; criticised for promulgation of Order No. 78, 247; Corp. Tanner appointed Register of Wills by, 248; G. A. R.'s approval of, 250; private pension bills passed during administration of, 279 .

Saulsbury, Senator, speech of, concerning claim agents, 194.

Schurz, Carl, Secretary of the Interior, opinion of, on Arrears Act, 163.

Secretary of the Interior, authorized to appoint special agent to prosecute frauds, 128: authority of, under law of 1893,118; under act of August $27,1888,135$; action of, on reratings, 227 ;
Secretary of the Treasury, administration of pensions by, 51 .

Secretary of War, administration of pensions transferred to, 51,54 ; power of, under act of 1792 , 56, under act of February $8,1793,60$; under law of 1803 , 62 , under act of 1818,68 , under act of March 3, 1819, 75; report of, on act of $1832,85$.

Service: in War of 1812, 60 days, 109; in Indian Wars, 30 days, 115; in Mexican War, 60 days, 117, 250, 259; in Civil War, 90 days, 126, 192, 236, 250, 258 261 ; special recognition of long and meritorious, 254, 258, 262

Service Pension Association, 205, note 2 , 221 , note 4.

Service-pension legislation: Revolutionary War (sec also Half pay): Act of 1818 67 ; 1 emedial act (May 1, 1820), 71; act of June 7, 1832, 81. Regular army, 99. War of 1812: act of February 14, 1871. 109 ; increase act of March 9, 1878, 110. Indian Wars: Act of July 27, 1892, 114 later acts, 115. Mexican War: Act of January 29, 1887, 117; later acts, 118. Civil War: act of June 27, 1890, 233. amending act, May 9, 1900, 242; act of May 11, 1912, 258.

Service-pensions: for Revolutionary offcers, see Half pay; for soldiers, first proposed by President Monroe, 65; other Presidential recommendations: Jackson, 77, Cleveland, 207, Harrison, 229 frauds, 87; Commissioner Baker's report on, 95; statistics, 113, 115, 119, 270 G'A. R.'s connection with, 205, 246, 249 254,260 ; agitation for, among claim agents and newspapers, 190, 194-196, 214 , 215-217; first granted during Civil War, 233; evils of, 237, 239; general discussion of system, 262-270.

Sherman, John, cost of arrears bill estimated by, 163, 169, 171; Arrears Act discussed by, 172 , note 2 ; views of, expressed in Senate, 191, 192; repeal of arrears limitation supported by, 231. See also $179,180$.

Sherwood, Gen. Isaac R., service-pension bill prepared by, 254; speech of, describing proceedings at G. A. R encampment, 255; comments of, on Sulloway bill, 256 . Sherwood service-pension bill, 254; comparison of, with Sulloway bill, 254; passed by House, 256.

Simple total disability rate, 135 .

Sisters, first provided for, 127, 128; further provisions under general law system, 139, 140,142; under War Insurance Law, 287, 289.

Slater, Senator, comments of, on Mexican War bill, 193

Smith, Senator Wm., speech of, opposing service-pensions, 66 .

Society of the Cincinnati, 46, 47, note $3 ; 52$. Soldiers' and Sailors' Association, 161.

Soldiers' and Sailors' insurance law, see War Insurance Law of 1917.

Soldiers' homes: occupants in 1915, 4, note 1: Chelsea Hospital, 11.

Southern states, absent from pension list in 1819,70 ; small pension expenditures in, 267.

Spain, war with: provisions for widows, 141, note 4; application of general law, 145 ; statistics, 145 . 
Special pension legislation, history of, and cause for, 275 ; low passed; 276, 277; vetoes of: Grant, 277; Cleveland, 278; number passed during various admin. istrations, 279; statistics, 280.

Specific disabilities, rates for, 129, 130 . 138, 239, 242; Commissioner Baker's report on, 131; difficulties in rating, 136 ; number of pensions granted for, to June $30,1888,138$.

State pension provision: Pennsylvania, 18, Virginia, 18; uniform method for, suggested by Continental Congress, 22 ; payments assumed by U. S., 54, 63 .

States, disbursements per capita among, in $1910,267,268,269$

Statistical tables: total annual payments for navy pensions, 106: War of 1812 pensions since 1871, 113; Indian Wars pensions since 1893, 115; Mexican $W$ ar vensions since 1887,119 ; statutory rates for permanent specific disabilities, 133, classification of all disabilities for which pensions were granted to June 30,1888 , 138; general law pensioners since 1865, 144: War with Spain and Philippine In surrection pensions since 1899, 145; regular establishment pensions since 1904, 146; relative amounts disbursed for first and subsequent payments, 1877.1899 , 203: per capita disbursements in states, 269; expenditures under act of 1890 (1891-1907), 270; number of Civil War pensioners, 1891-1907, 271; number of Civil War pensioners, 1907-1917, 272; disbursements for pensions and maln tenance of pension system, 1866-1917, 273 ; total amount of pensions, 1790.1917, 274 ; special pension legislation, 280 ; premiums under War Insurance Law, Oct. 6 1917,295

Surgeons, fees for examination by, 128 ; instructions to, by Cominissioner Evans, 243.

Surplus, Treasury, relation of, to pensions, $64,65,69,91,96,222,249,263$.

Sulloway bill, 254 , note $1,255,256$.

Taft, President Wm. H., opposition of, to Sulloway bill, 256; service-and-age bill signed by, May 11, 1412; 258; special pension acts passed durıng administration of, 279.

Taney, Chief Justice Roger B., opinion of, in U. S. v. Ferreira, 58

Tanner, Corp. James, report of, to G. A. R., 181; activities of, as member of G. A.' R. Committee on Pensions, 188; Geo. E. Lemon defended by, 218, note 1 ; appointed Commissioner of Pensions, 226; rerating by, 226; salaries of employes raised by, 227; liberality checked by Secretary of the Interior, 227; resignation of, 228; G. A. R.'s endorsement of, 226, 229, note 1; Evans attacked by 244 , note 1; appointed Register of Wills, 248; elected Commander-inChief, G. A. R., 248 .

Thurman, Senator Allen G., comment of, on cost of arrears bill, 169; nominated for vice-president, 223 .

Todd, Yale, case of, 59, 60.
Total disability, rates for, $108,111,115$, $118,126,132,134,135,137$

Traditional evidence accepted as proof of claims, 82.

Treasury, condition of, in relation to pension legislation, $64,65,69,72,91,96$, $222,248,249,263$.

U. S. v. Ferreira, 58.

U. S. v. Yale Todd, 59, 60.

Vest, Senator G. G., comments of, on Mexican War bili, 193; on G. A. R., 220, note 4.

War Insurance Law of 1917 , history and administration of, 283; leading features of, 284-286; outline of provisions and sciledules, 287, premiums under, 295.

War of 1812: first provisions for survivors, widows and orphans, 108; service-pensions granted, 1871, 109; restrictions on widows' pensions, 110 ; more liberal provisions in act of Marcin 9, 1878, 110; requirement of loyalty abolished, 111; last survivor, 112; statistics concerning, 113.

War of 1812 pension act (1871), 109, 149.

War Risk Insurance, bureau of, 283.

War with Spain, see Spain, war with.

Ware, Eugene F. Commissioner of Pensions, appointed by President Roosevelt, 246.

Warner bill, 190.

Warner, Representative, claim agents criticised by, 215, 216, 217.

Washington, George, "remarks" of, on Col. Bland's proposals, 24; letters to President of Congress, $24,26,27,30,33,34$, $40,41,42$; memorial to Congressional committee, 25 ; correspondence with: John Banister, 28, Gouverneur Morris, 30, 31, a committee of Congress, 30, John Arm. strong, 31, Joseph Jones, 32, 36, 37, 40, Gen. Lincoln, 36; circular letter to governors of all states, 42; defense of distinction between officers and privates by, 43,52 ; judges' protest to, 56.

Webster, Noah, Commutation Act de. fended by, 46, 48.

Widows: English relief for, 12; Colonial provisions, 15-17; state provisions, 18; Washington's efforts in behalf of, 25; 31; first national provisions, 33; summary of Revolutionary legislation, 9196; regular army provisions, 99; regular navy provisions, 103 ; War of 1812,108 . 111, 113; Indian Wars, 114, 115; Mexican War, 116, 119; Civil War: general law, 125.127, 139-142, 144; Arrears Act, $174,192,200,201$; act of $1890,235,237$; act of $1900,243,244$; later acts, 251 253, 258-262; War with Spain and Pbilippine Insurrection, 141, 145 ; regular establishment, 146; under War Insurance Law, 284, 288-291.

Widows' Pension bili (April 19, 1908), provisions and effect, 251 ; expenditures under, 252

Wilson, Woodrow, War Insurance Law signed by, 283; joint resolution extending time for application for insurance approved by, 286 , note 1 , 


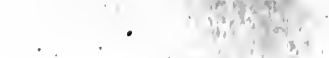






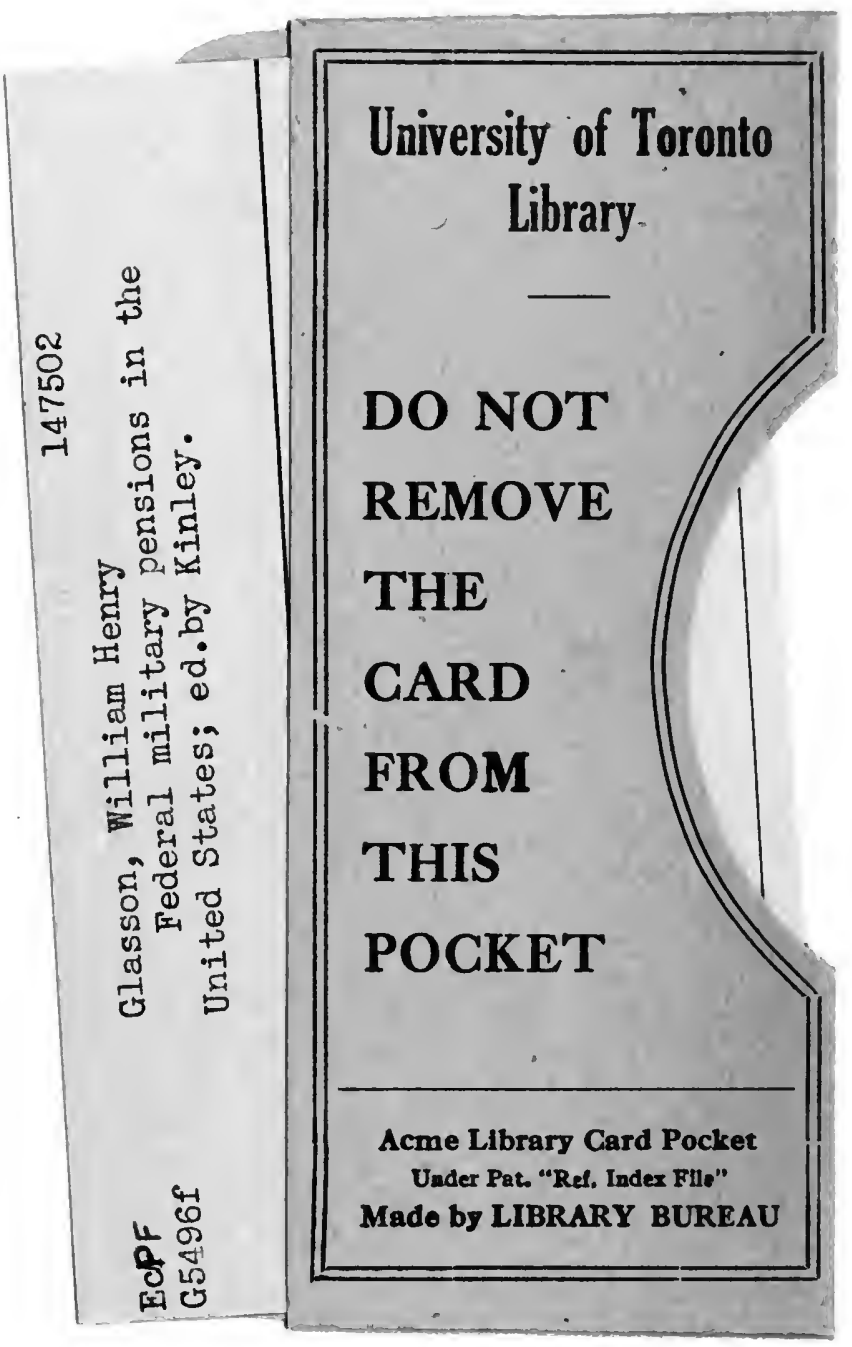


